\section{Pacific Northwest}

National Laboratory

Operated by Battelle for the

U.S. Department of Energy

\title{
Geologic and Wireline Summaries from Fiscal Year 2002 ILAW Boreholes
}

\author{
S. P. Reidel \\ A. M. Ho
}

September 2002

Prepared for the U.S. Department of Energy under Contract DE-AC06-76RL01830 


\section{Geologic and Wireline Summaries from Fiscal Year 2002 ILAW Boreholes}

S. P. Reidel

A. M. Ho

September 2002

Prepared for

the U.S. Department of Energy

under Contract DE-AC06-76RL01830

Pacific Northwest National Laboratory

Richland, Washington 99352 


\section{Summary}

Four boreholes were drilled at the Immobilized Low-Activity Waste Disposal Site in April 2002. Three were completed as groundwater monitoring wells. This report documents the drilling and data collected from the drilling. 


\section{Contents}

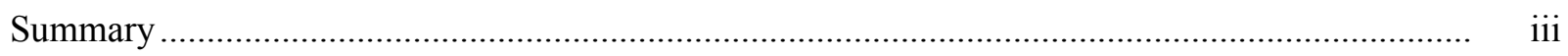

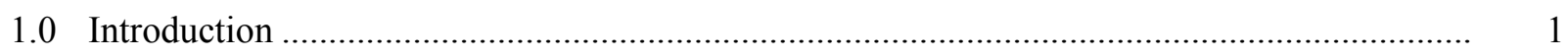

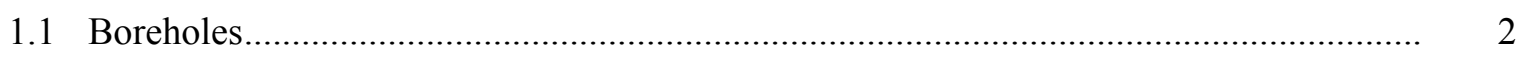

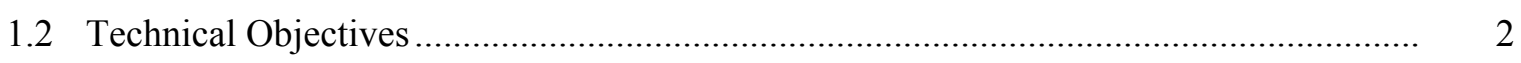

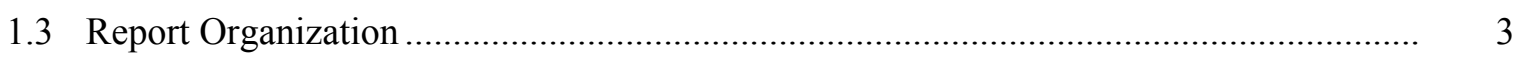

2.0 ILAW Drilling and Sampling Activities...................................................................

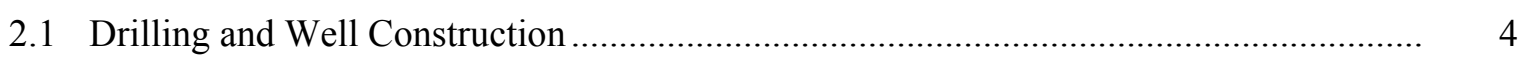

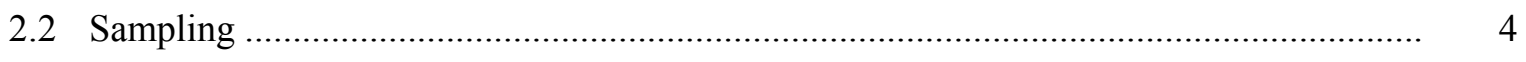

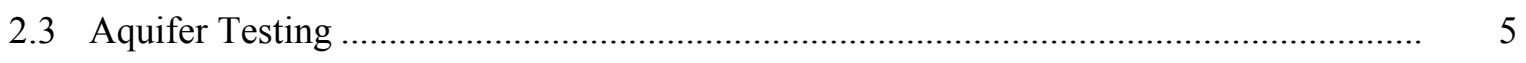

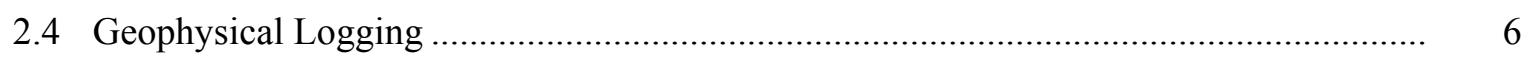

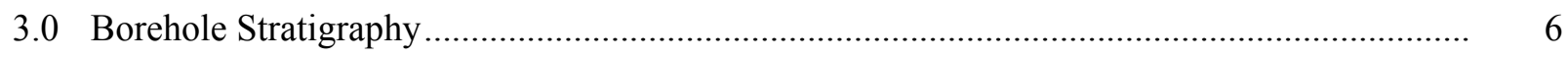

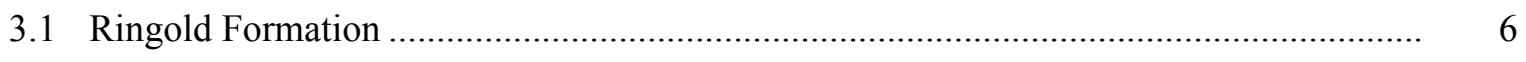

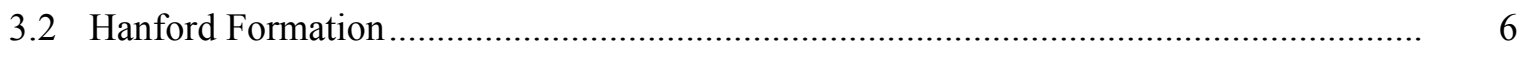

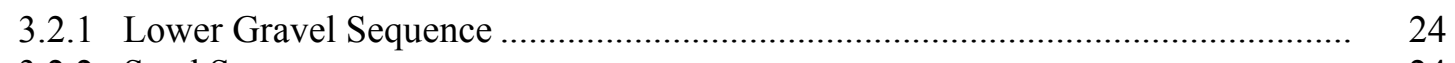

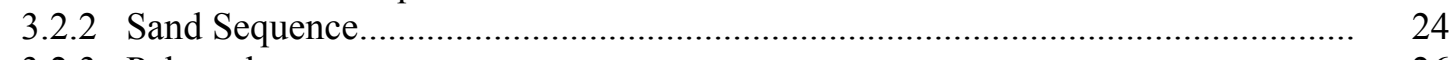

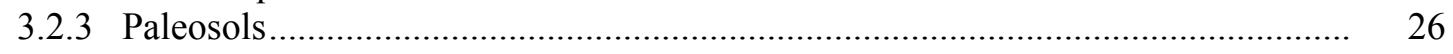

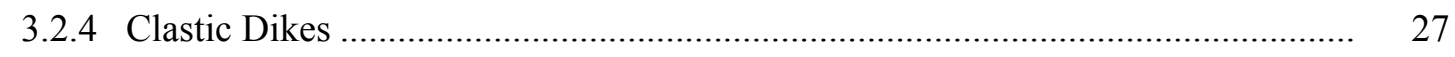

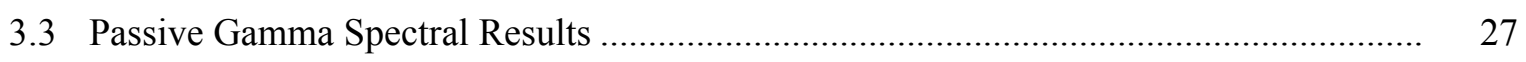

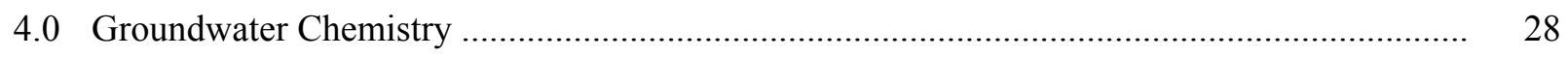

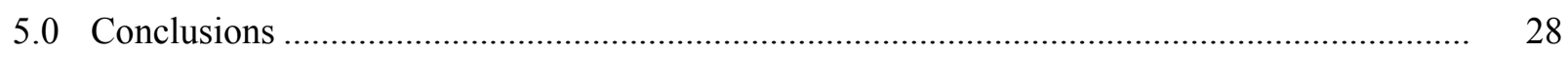

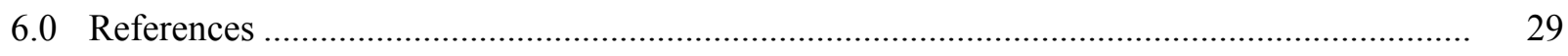

Appendix A - Well Summary Report for 2002 ILAW Well Installations.................................... A.1

Appendix B - Description of Core from Borehole C3826 ....................................................... B. 1

Appendix C - Description of Core from Borehole C3827 ................................................... C.1

Appendix D - Description of Core from Borehole C3828 ................................................. D. 1

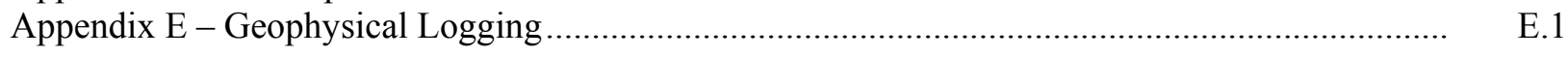




\section{Figures}

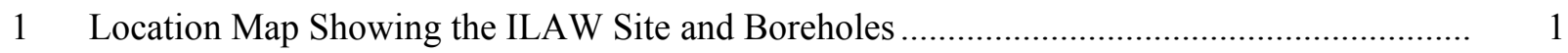

2 Location of Boreholes Drilled at the ILAW Site .......................................................... 5

3 Stratigraphy Across the ILAW Site Based on Pre-FY 2002 Data ....................................... 7

4 Summary of the Stratigraphy and Lithology of Borehole C3826 ..................................... 8

5 Summary of the Stratigraphy and Lithology of Borehole C3827 ..................................... 12

6 Summary of the Stratigraphy and Lithology of Borehole C3828 ...................................... 16

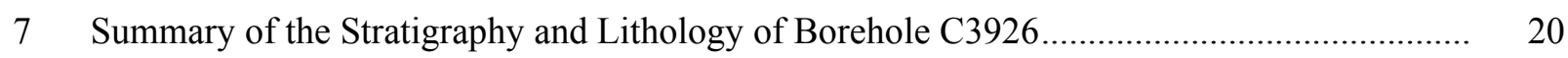

8 Basal Gravel from Borehole C3826 at the ILAW Site ..................................................... 25

9 Sand-Dominated Unit from Borehole C3826, 60.0-61.0 Feet, at the ILAW Site..................... 26

10 Paleosol from Borehole C3826, Depth 30.5-31.5 Feet..................................................... 27

11 Clastic Dike Penetrated in Borehole C3828 ................................................................... 28

\section{Tables}

1 Boreholes Drilled at ILAW Site During FY 2002 ......................................................... 2

2 Intervals Selected for Continuous Coring ..................................................................... 3

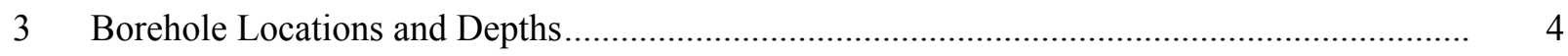

4 Thickness and Depth of the Hanford Formation Encountered in Boreholes ........................... 24

5 Summary of the Geology and Lithology of Boreholes C3826, C3827, C3828, and C3926..... 25

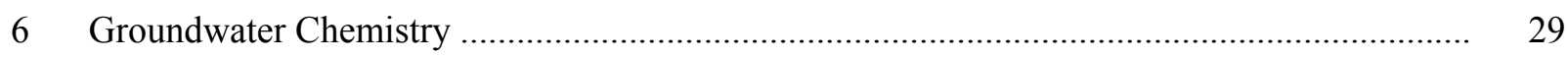




\subsection{Introduction}

The U.S. Department of Energy Office of River Protection is responsible for safe underground storage of liquid waste from previous Hanford Site operations, the storage and disposal of immobilized tank waste, and closure of underground tanks. The current plan is to dispose of immobilized low-activity tank waste (ILAW) in the south-central part of the 200 East Area (Figure 1).

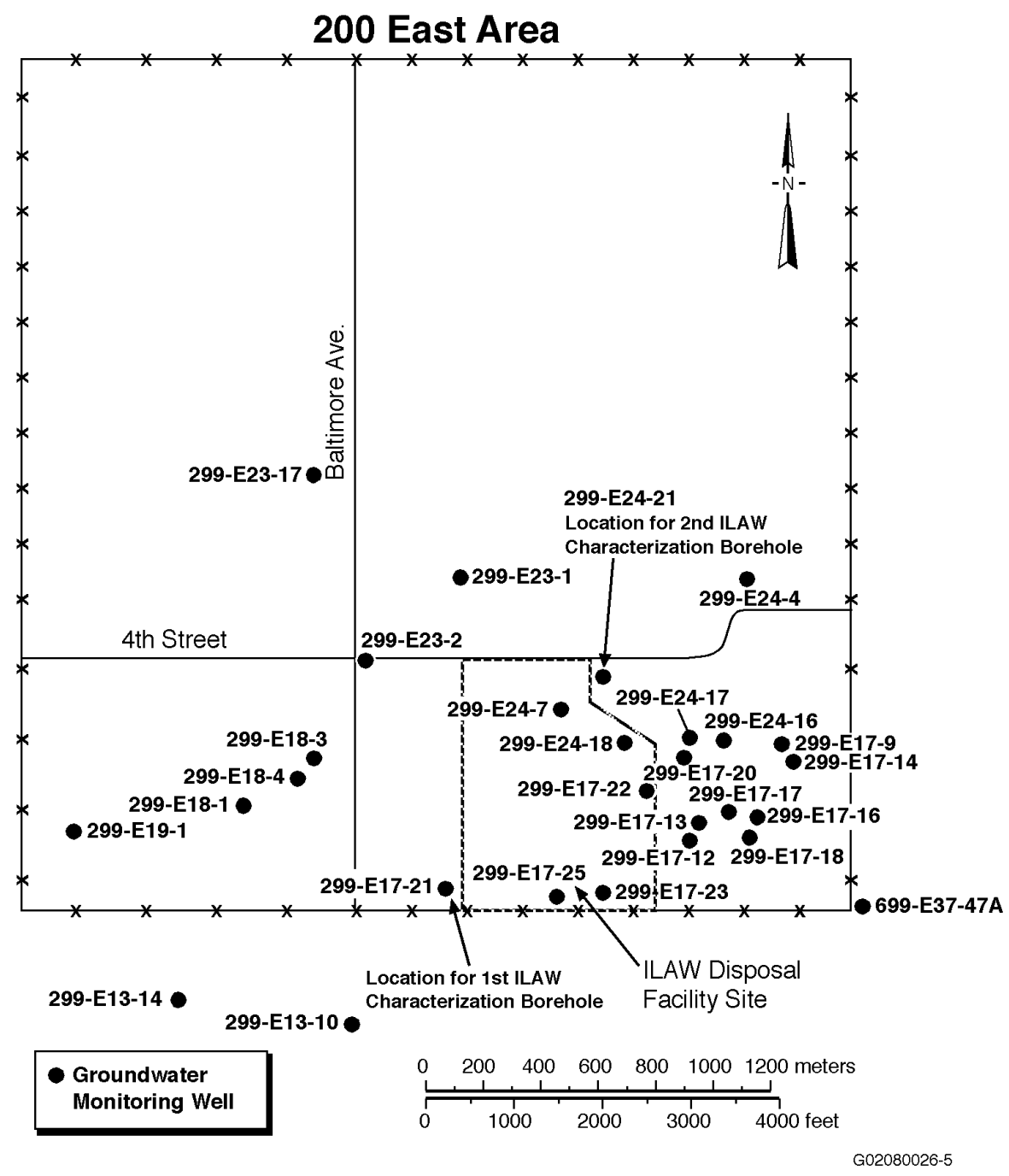

Figure 1. Location Map Showing the ILAW Site and Boreholes

This report summarizes the results of FY 2002 drilling, geologic logging of cores, geophysical logging of the boreholes and preliminary groundwater chemistry from the wells. The drilling and testing activities associated with the boreholes were done in accordance with the Characterization Plan (Reidel 2002). 
This report uses the English system of units where discussing drill depth, as it is customary to report borehole depth data in feet rather than meters. Multiply feet by 0.3048 to convert to meters. All other measurements are in metric units.

\subsection{Boreholes}

Four boreholes (Table 1) were drilled along the south and east sides and at the southeast corner of the ILAW site (Figure 1) in April 2002 in support of the Performance Assessment (PA) activities, to establish a groundwater-monitoring network, and to help establish a pre-operational environmental baseline (Mann et al. 2001; Horton et al. 2000). Three of these boreholes were then completed as groundwater monitoring wells. Walker (2002) provides a summary report of all field activities including drilling and well construction (see Appendix A).

Table 1. Boreholes Drilled at ILAW Site During FY 2002

\begin{tabular}{||c|c||}
\hline Borehole Number & Well Name \\
\hline \hline C3826 & 299-E17-22 \\
\hline C3827 & 299-E17-23 \\
\hline C3828 & Decommissioned \\
\hline C3926 & 299-E17-25 \\
\hline
\end{tabular}

Three of the four boreholes were completed as groundwater monitoring wells (Table 1). Borehole C3828 was drilled and then decommissioned when a measurement critical to insure proper placement of the silica sand pack around the well screen could not be made (Walker 2002). Borehole C3926 was drilled approximately $3 \mathrm{~m}$ west of borehole C3828 and completed as a groundwater monitoring well.

\subsection{Technical Objectives}

The technical objectives of the boreholes were:

- To provide geologic samples to characterize the sediments in the vadose zone in support of the ILAW Performance Assessment and the pre-operational monitoring plan (Horton et al. 2000). This includes physical, hydrologic, and geochemical characterization.

- To install groundwater monitoring wells to establish a pre-operational groundwater baseline.

The primary factor dictating the location of the boreholes was their characterization function with respect to developing the geohydrologic model for the site in support of the PA (Mann et al. 2001), satisfying associated Data Quality Objectives (Reidel et al. 1995; Reidel 2002 [Appendix C, Section 3.2]) and providing information for pre-operational environmental baseline characterization (Horton et al. 2000). 


\subsection{Report Organization}

This report consists of six chapters and five appendices. The first chapter is the introduction and background for the project. Chapter 2 provides a summary on the drilling and sampling methods that were used. Chapter 3 summarizes the borehole stratigraphy. Chapter 4 contains a brief discussion on the groundwater chemistry, Chapter 5 a summary and conclusions, and Chapter 6 lists cited references. The well summary report of Walker (2002) is reproduced in Appendix A, and Appendices B, C, and D contain core descriptions. A summary of the geophysical logging is found in Appendix E.

\subsection{ILAW Drilling and Sampling Activities}

Drilling, sampling, and well construction objectives for the project are presented in Reidel (2002). That report called for drilling and sampling of three boreholes to be constructed as groundwater monitoring wells. Continuous sample retrieval from selected intervals was needed to achieve the goals of the sampling plan (Table 2).

Table 2. Intervals Selected for Continuous Coring (Reidel 2002)

\begin{tabular}{||l|c|c|c|c|c|c||}
\hline \multirow{2}{*}{$\begin{array}{c}\text { Depth } \\
\text { (ft bgs) }\end{array}$} & \multicolumn{3}{|c|}{ Borehole } & \multirow{2}{*}{$\begin{array}{c}\text { Physical } \\
\text { Properties }\end{array}$} & $\begin{array}{c}\text { Recharge } \\
\text { Tracers }\end{array}$ & $\begin{array}{c}\text { Aquifer } \\
\text { Study }\end{array}$ \\
\cline { 2 - 5 } $8-4826$ & $\mathrm{C} 3827 \mathrm{~B}$ & $\mathrm{C} 3828$ & $\mathrm{X}$ & $\mathrm{X}$ & \\
\hline \hline $54-58$ & $\mathrm{X}$ & & & $\mathrm{X}$ & $\mathrm{X}$ & \\
\hline $58-62$ & $\mathrm{X}$ & $\mathrm{X}$ & $\mathrm{X}$ & $\mathrm{X}$ & $\mathrm{X}$ & \\
\hline $62-66$ & & $\mathrm{X}$ & $\mathrm{X}$ & $\mathrm{X}$ & $\mathrm{X}$ & \\
\hline $64-68$ & $\mathrm{X}$ & & & $\mathrm{X}$ & $\mathrm{X}$ & \\
\hline $68-72$ & $\mathrm{X}$ & & & $\mathrm{X}$ & $\mathrm{X}$ & \\
\hline $72-76$ & $\mathrm{X}$ & & & $\mathrm{X}$ & $\mathrm{X}$ & \\
\hline $76-80$ & $\mathrm{X}$ & $\mathrm{X}$ & & $\mathrm{X}$ & $\mathrm{X}$ & \\
\hline $96-100$ & $\mathrm{X}$ & $\mathrm{X}$ & & $\mathrm{X}$ & $\mathrm{X}$ & \\
\hline $120-124$ & $\mathrm{X}$ & $\mathrm{X}$ & & $\mathrm{X}$ & $\mathrm{X}$ & \\
\hline $150-154$ & $\mathrm{X}$ & $\mathrm{X}$ & & $\mathrm{X}$ & $\mathrm{X}$ & \\
\hline $154-158$ & & $\mathrm{X}$ & $\mathrm{X}$ & $\mathrm{X}$ & $\mathrm{X}$ & \\
\hline $158-162$ & & $\mathrm{X}$ & $\mathrm{X}$ & $\mathrm{X}$ & $\mathrm{X}$ & \\
\hline $162-166$ & & $\mathrm{X}$ & $\mathrm{X}$ & $\mathrm{X}$ & $\mathrm{X}$ & \\
\hline $164-168$ & $\mathrm{X}$ & & & $\mathrm{X}$ & $\mathrm{X}$ & \\
\hline $168-172$ & $\mathrm{X}$ & & & & & \\
\hline $172-176$ & $\mathrm{X}$ & & & $\mathrm{X}$ & $\mathrm{X}$ & \\
\hline $180-184$ & $\mathrm{X}$ & $\mathrm{X}$ & & & & \\
\hline $220-224$ & $\mathrm{X}$ & $\mathrm{X}$ & & & & \\
\hline
\end{tabular}




\subsection{Drilling and Well Construction}

The details of drilling, well construction, and well development are documented in Walker (2002); surveyed borehole locations and depths are given in Table 3 and Figure 2. In summary, the boreholes were drilled in April 2002 using the Becker Hammer drilling method from the surface into the saturated zone.

Table 3. Borehole Locations and Depths (from Walker 2002 and Appendix A)

\begin{tabular}{||c|c|c|c|c|c||}
\hline \hline Borehole Number & Well Name & East $^{(\mathrm{a}, \mathrm{b})}(\mathrm{m})$ & North $^{(\mathrm{a}, \mathrm{b})}(\mathrm{m})$ & Elevation $^{(\mathrm{a}, \mathrm{b})}(\mathrm{m})$ & Water Table $^{(\mathrm{b})}\left(\mathrm{ft} \mathrm{bgs}^{\prime}\right.$ \\
\hline \hline C3826 & $299-E 17-22$ & 574841.067 & 135195.921 & 220.589 & 321.82 \\
\hline C3827 & 299-E17-23 & 574694.485 & 134842.766 & 223.843 & 332.5 \\
\hline C3828 & Not Applicable & 574518.125 & 134845.545 & 224.801 & 341.3 \\
\hline \multicolumn{7}{|c|}{ C3926 } & 299-E17-25 & 574515.171 & 134845.913 & 225.028 & 337.67 \\
\hline $\begin{array}{l}\text { (a) Brass cap. } \\
\text { (b) From Walker (2002). }\end{array}$ \\
\hline
\end{tabular}

The boreholes were completed as Resource Conservation and Restoration Act groundwatermonitoring wells. Each well has a 4-in diameter stainless steel casing and a 35-ft long stainless steel, continuous wire wrap, 20-slot (0.020-in.) screen. A protective casing with locking cap, a cement pad, and protective posts were installed to complete the surface installations.

The wells were developed in May 2002 with a 3-hp submersible pump used at two depths. Water was pumped at a rate of 13 (299-E17-22), 11 (299-E17-23), and 12 (299-E17-25) gallons per minute; there was no measurable drawdown (Walker 2002; Appendix A). Groundwater samples were taken at the end of well development for analysis of selected parameters (see Chapter 4).

\subsection{Sampling}

Walker (2002; Appendix A) described the field sampling activities associated with drilling the boreholes. Briefly, split-tube samples were collected in 4-in diameter, $1 \mathrm{ft}$ (C3826 and C3827) or $2 \mathrm{ft}$ (C3828) long lexan liners. Table 2 summarizes the intervals collected. No split-spoon samples were collected from C3926 because it was only about $3 \mathrm{~m}$ west of C3828. Grab samples were collected every $5 \mathrm{ft}$ from all four boreholes for archive purposes.

End caps were taped to each lexan liner, and then the liners were double-bagged in plastic and placed in ice chests with an additional layer of plastic between the samples and the ice for transportation to the laboratory. Samples were transported under chain-of-custody and stored in refrigerators in the 3720 Building until they were opened for examination. 


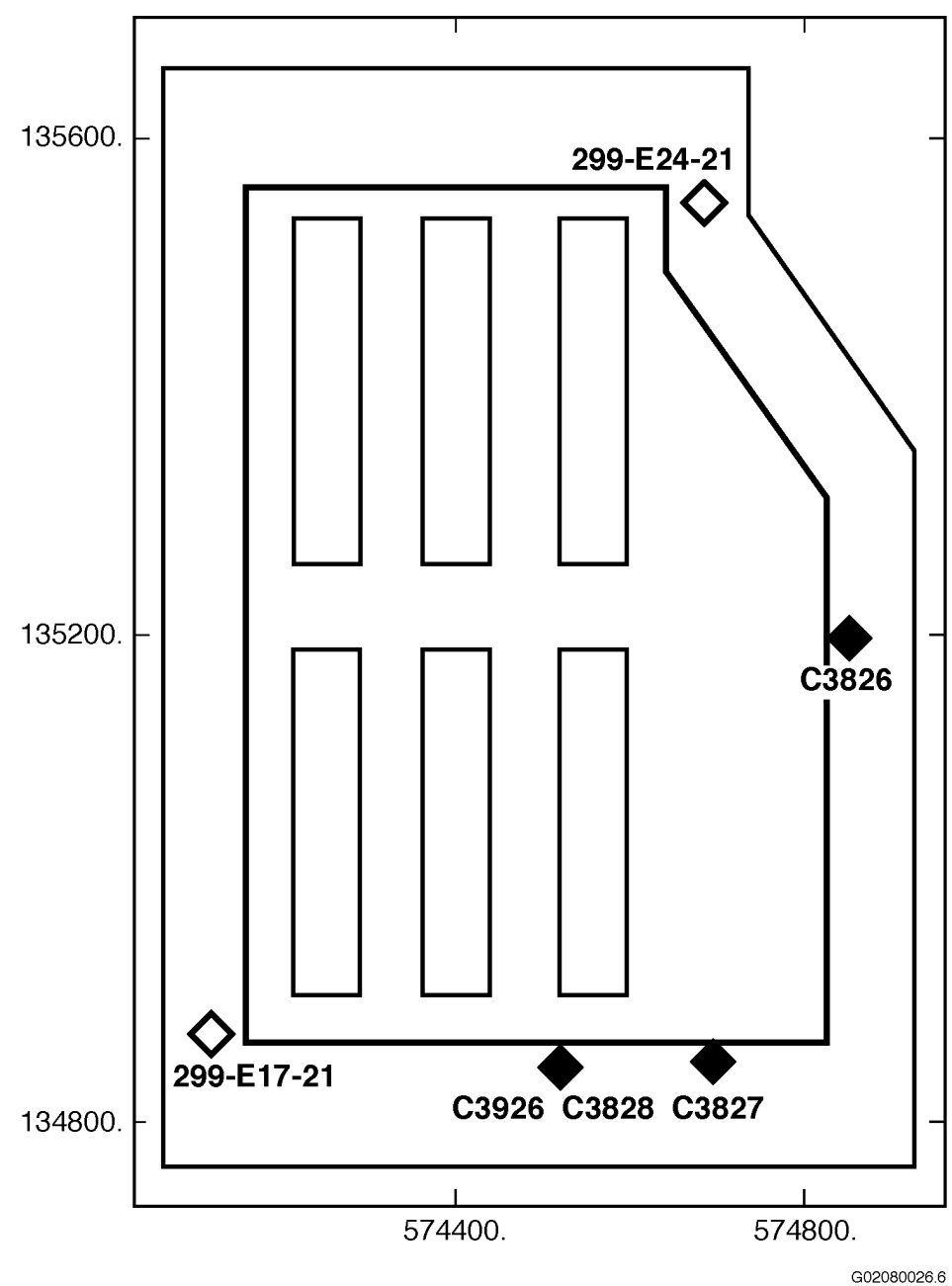

Figure 2. Location of Boreholes Drilled at the ILAW Site

The lexan liners containing the cores from the boreholes were split open in the laboratory and logged following the approved test plan (Reidel 2002). Each sample was photographed, and detailed geologic descriptions made in the laboratory included geologic structure, grain-size, grain shape, sorting, color, moisture, cementation, hardness, and reaction to $\mathrm{HCl}$ (see Appendices B, C, and D). Sample liners were resealed with tape after examination and will be archived in the Hanford Geotechnical Sample Library.

\subsection{Aquifer Testing}

The Sampling and Analysis Plan (Reidel 2002) outlined a testing program for the hydrologic properties of the well. This testing was designed to provide information on recovery rates, effective permeability and other hydrologic properties for the zone in which the aquifer was screened. Testing was done in August 2002 and consisted of slug withdrawal tests. Results of the analyses will be reported separately. 


\subsection{Geophysical Logging}

The boreholes were geophysically logged in August 2002. High-purity germanium logging was conducted to determine the presence of man-made gamma emitting radioisotopes, and to provide analysis of naturally-occurring potassium, thorium, and uranium for stratigraphic studies. Appendix E contains copies of the $\log$ suite and the logging analysis report. No man-made radioactive materials were detected

\subsection{Borehole Stratigraphy}

The boreholes penetrated sediments comprising the Hanford formation and possibly the Ringold Formation in C3828 and C3926. The main elements of the stratigraphy around the ILAW site are shown in Figures 3 through 7. Appendices B, C, and D present a description of the individual cores as they were opened. The well-site geologist's descriptions (Walker 2002; Appendix A) are in good agreement with the lithology and stratigraphy observed in the core. Small-scale features that generally are destroyed during drilling are well preserved in the core, thus allowing a better understanding of the site.

The stratigraphic nomenclature used in this report is consistent with the standardized nomenclature used for the Hanford Site (i.e., Delaney et al. 1991; Reidel et al. 1992; Lindsey et al. 1994; DOE 2002) and with that used in the description of the sediments encountered in the first two ILAW boreholes (299E17-21 and 299-E24-21; Reidel et al. 1998, 2001).

\subsection{Ringold Formation}

The Ringold Formation may have been encountered in boreholes C 3828 and C3926 (Figures 3 and 7) based on the well-site geologists logging of the cuttings. Identification of the Ringold Formation is difficult using drill cutting at the ILAW site because of the similarity of the lithologies of the Hanford formation and the Ringold Formation in that area. The amount of water produced by the formations and the presence of cementation are two criteria that can help distinguish the two.

\subsection{Hanford Formation}

The thickness and depths of the Hanford formation encountered in the boreholes is given in Table 4. The entire thickness of the Hanford formation at boreholes C3826 and C3827 is not known because these boreholes did not penetrate the underlying Ringold Formation. The Hanford formation consists of pebble to cobble conglomerate and fine- to coarse-grained sand with a few interbedded, thin silt and/or clay beds. It is divided at the ILAW site into a lower gravel and an overlying sand unit with sparse gravel layers. 
A

Southwest

299-E13-10

El. $735^{\prime}$

Drilled
Dopth

Dopth
(Feet) CZSG

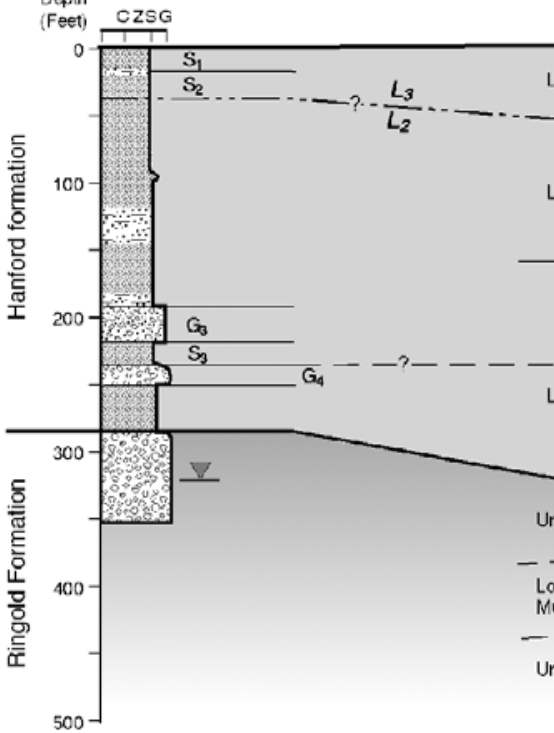

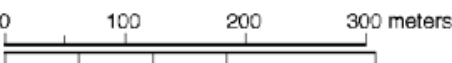

ILAW Site

299-E24-7

El. 716
$A^{\prime}$

Northeast

299-E17-21

El. 735

0256
299-E24-21

El. $715^{\prime}$
299-E24-4

El. 697
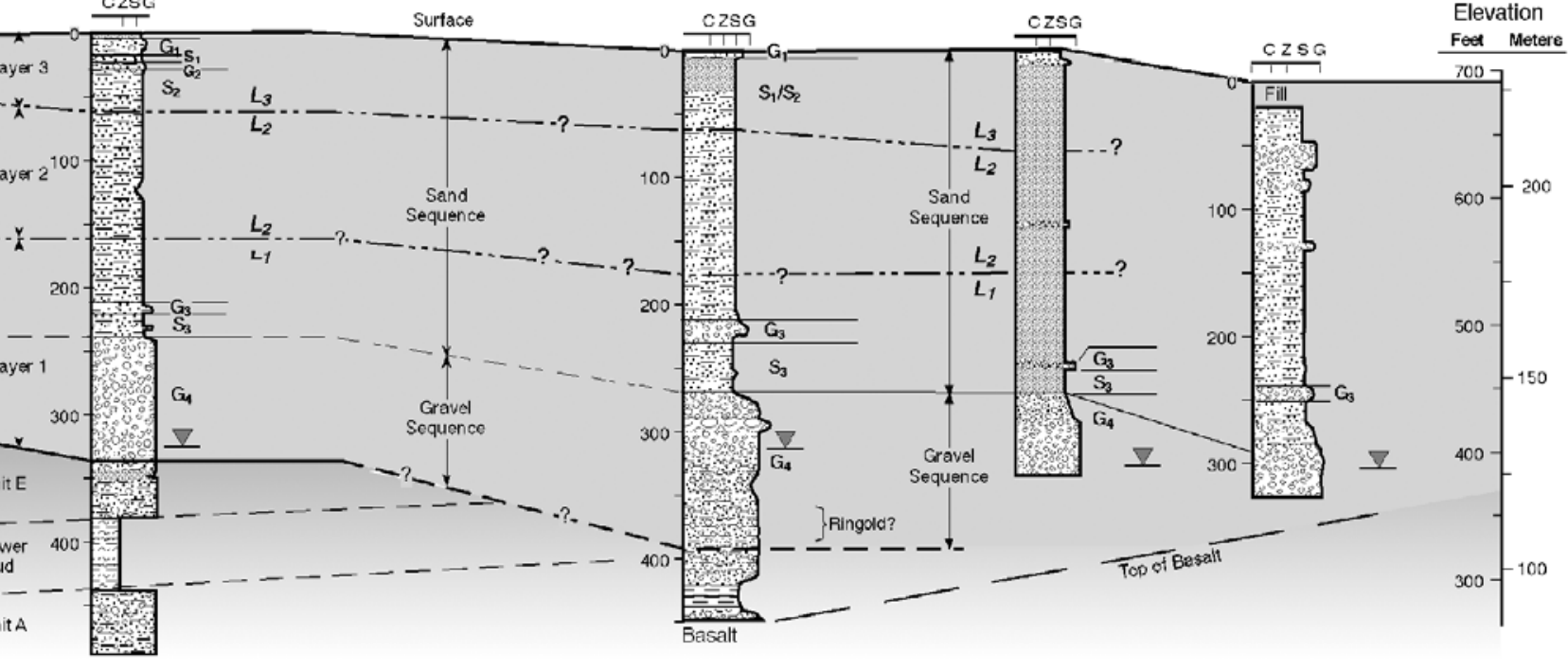

Modified to remove
casing joint effect

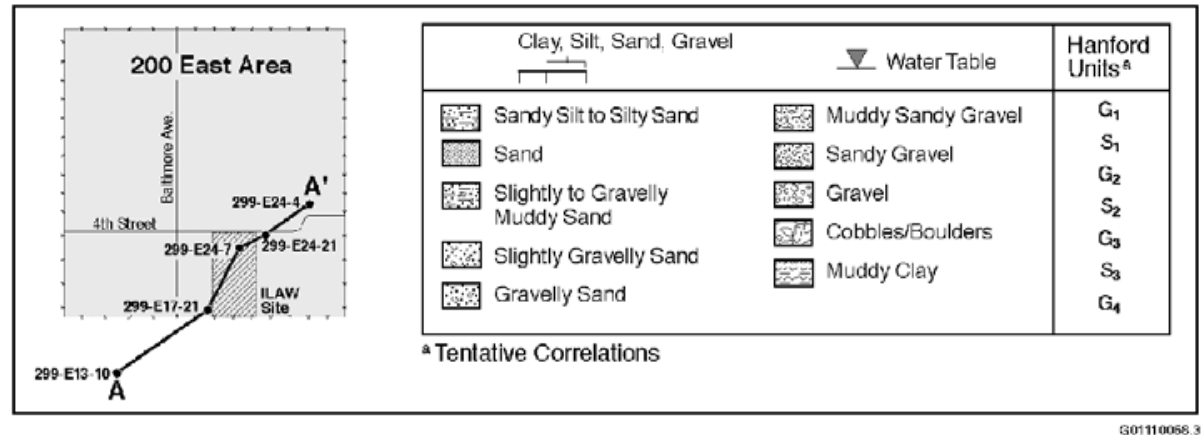

Figure 3. Stratigraphy Across the ILAW Site Based on Pre-FY 2002 Data 


\section{C3826 (299-E17-22)}
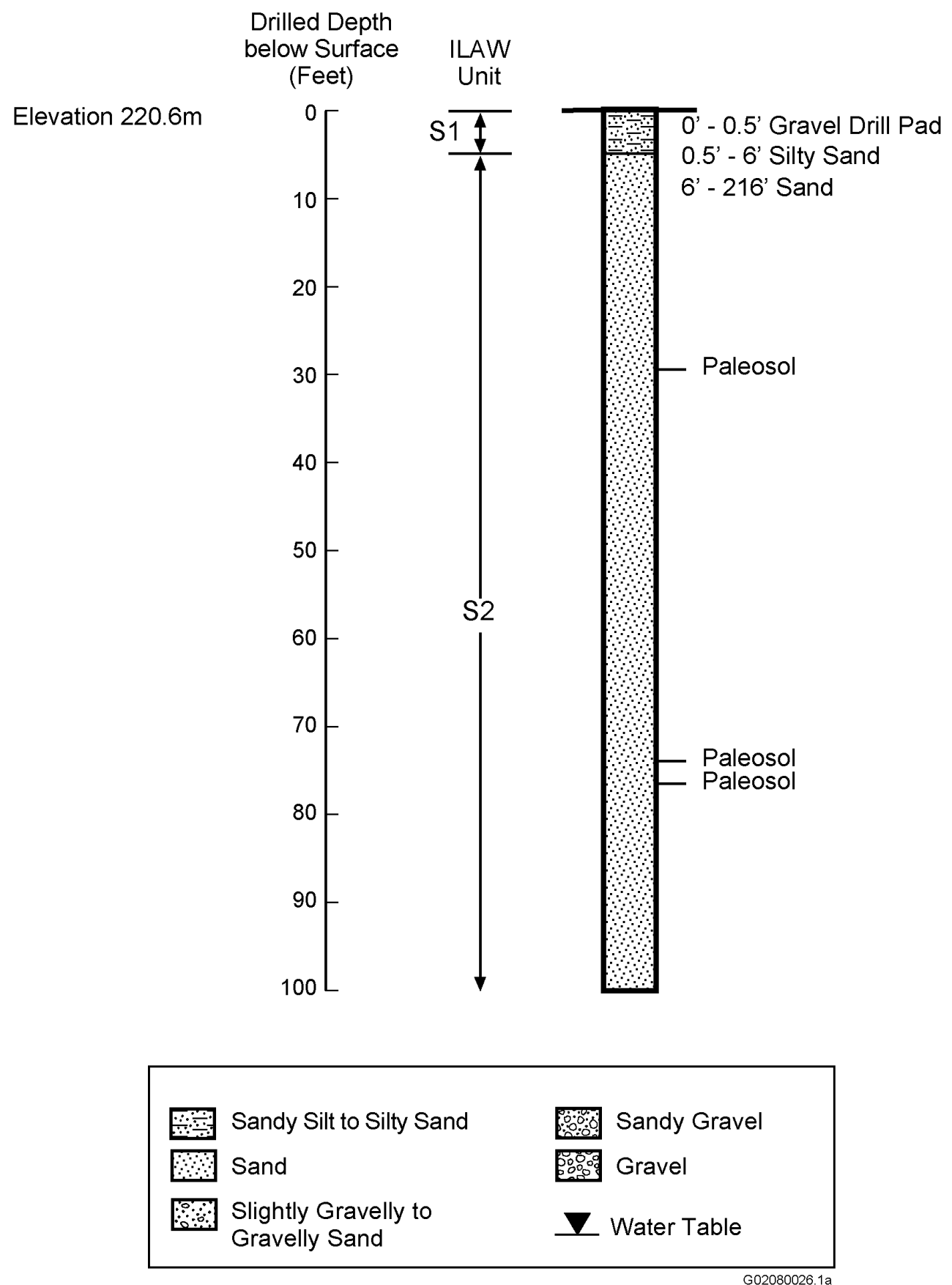

Figure 4. Summary of the Stratigraphy and Lithology of Borehole C3826. ILAW unit refers to sand layers (S) and gravel layers (G) previously observed at the ILAW site. Also see Figure 3. 


\section{C3826 (299-E17-22)}

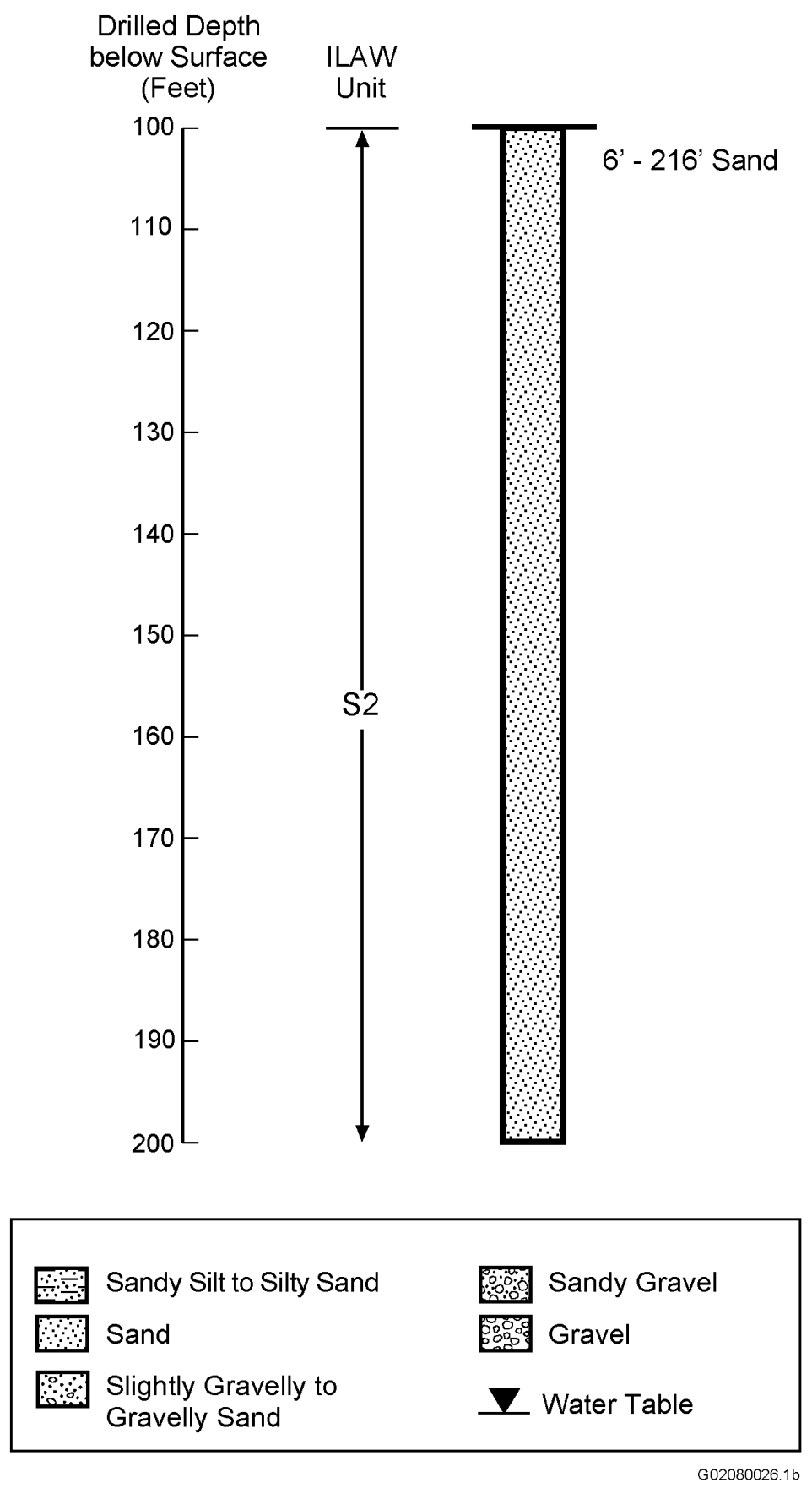

Figure 4. (contd) 


\section{C3826 (299-E17-22)}

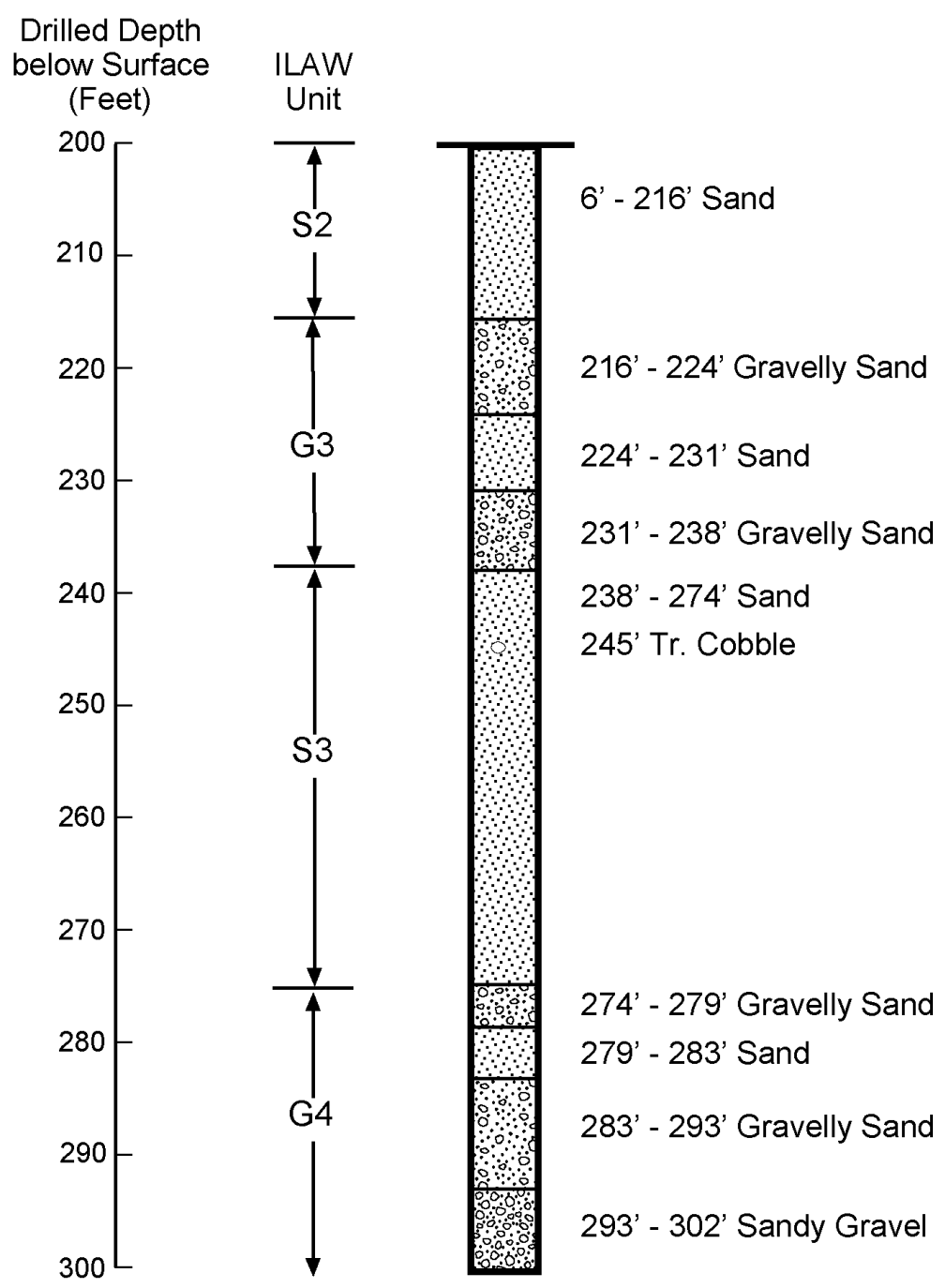

\section{Sandy Silt to Silty Sand Sandy Gravel \\ Sand Gravel \\ Slightly Gravelly to
Gravelly Sand}

G02080026.1c

Figure 4. (contd) 


\section{C3826 (299-E17-22)}

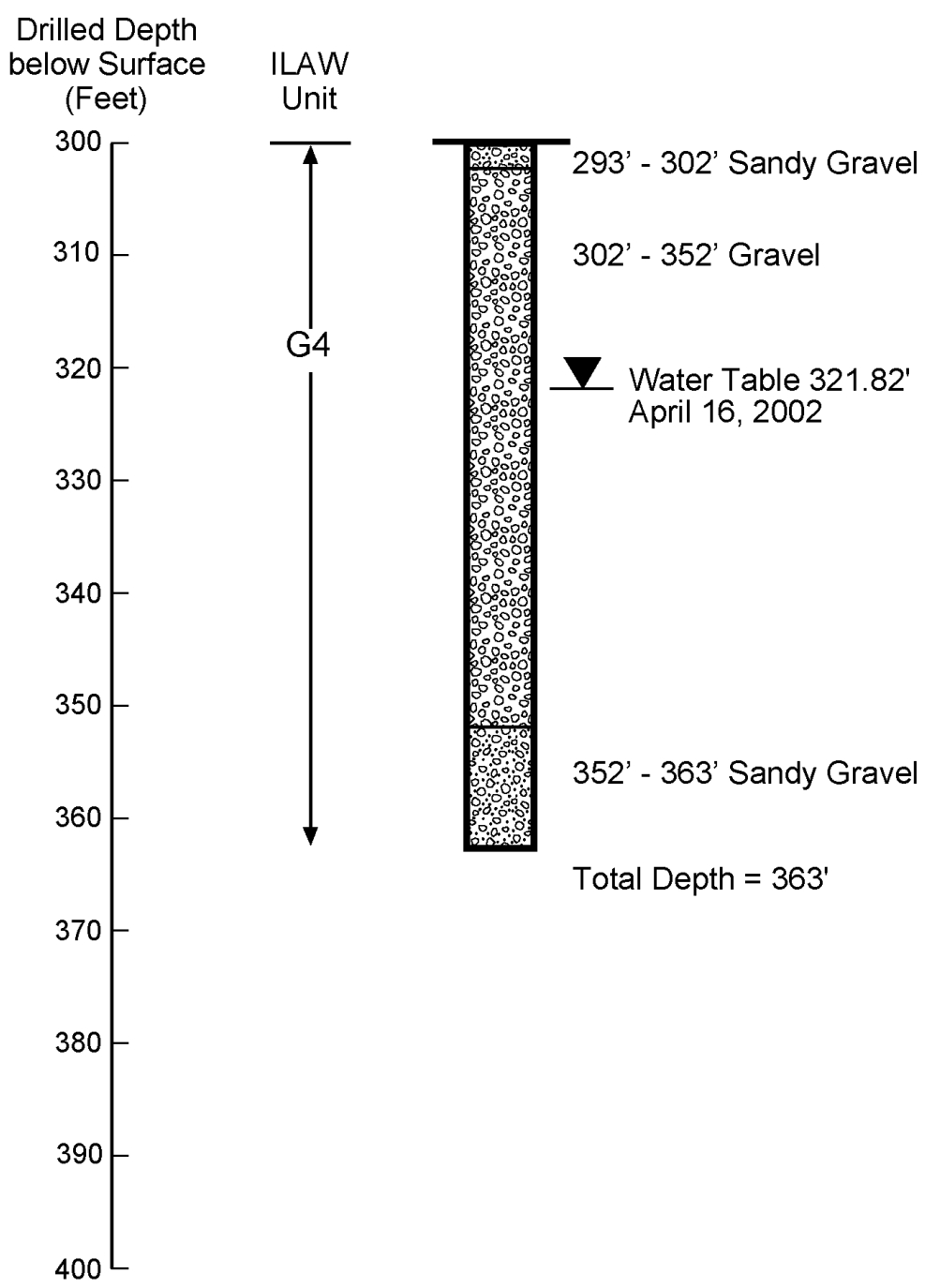

\section{Sandy Silt to Silty Sand Sandy Gravel \\ Sand \\ Fog Gravel \\ Slightly Gravelly to \\ Gravelly Sand \\ $\nabla$ Water Table}

G02080026.1d

Figure 4. (contd) 


\section{C3827 (299-E17-23)}
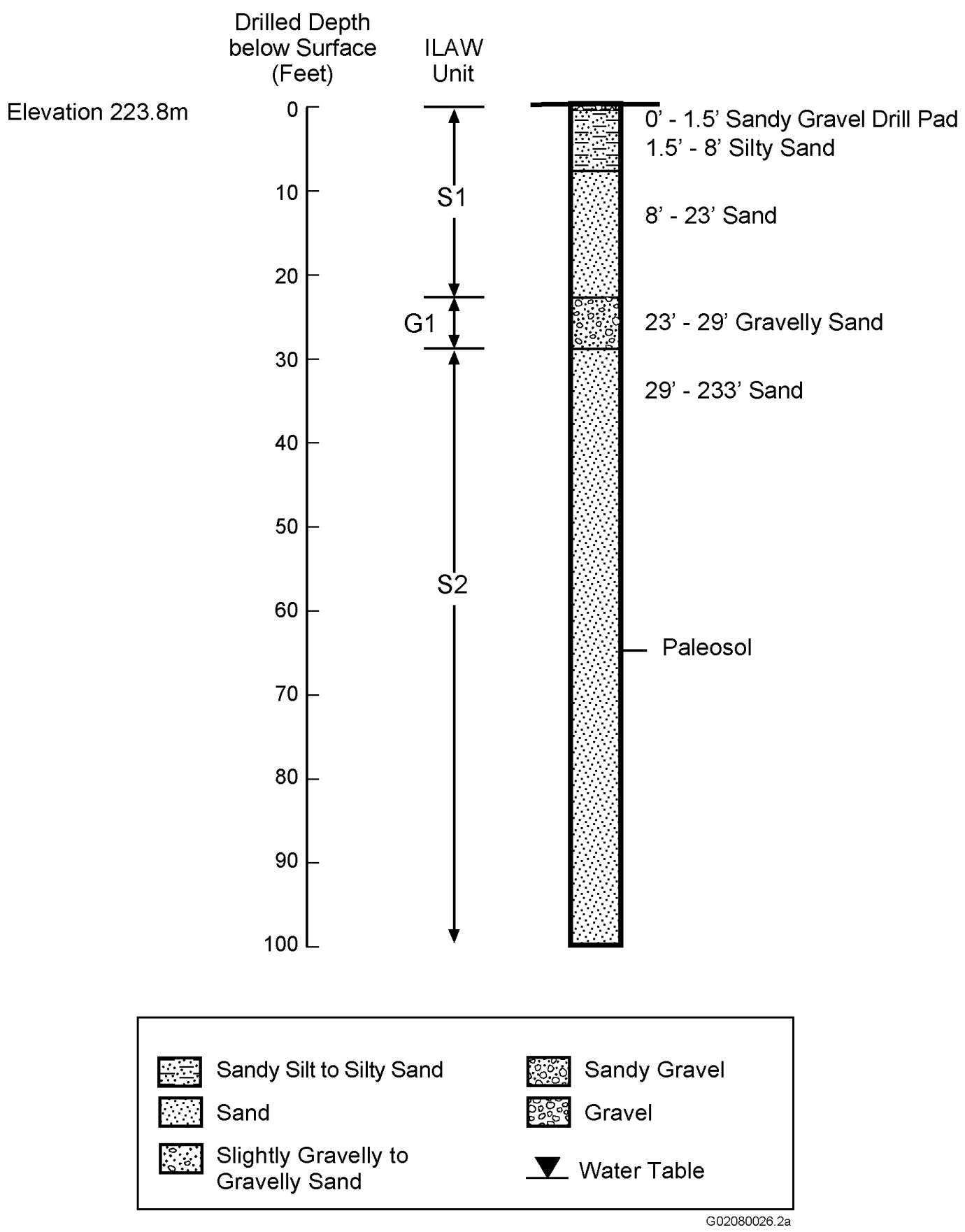

Figure 5. Summary of the Stratigraphy and Lithology of Borehole C3827.

ILAW unit refers to sand layers (S) and gravel layers (G) previously observed at the ILAW site. Also see Figure 3. 


\section{C3827 (299-E17-23)}

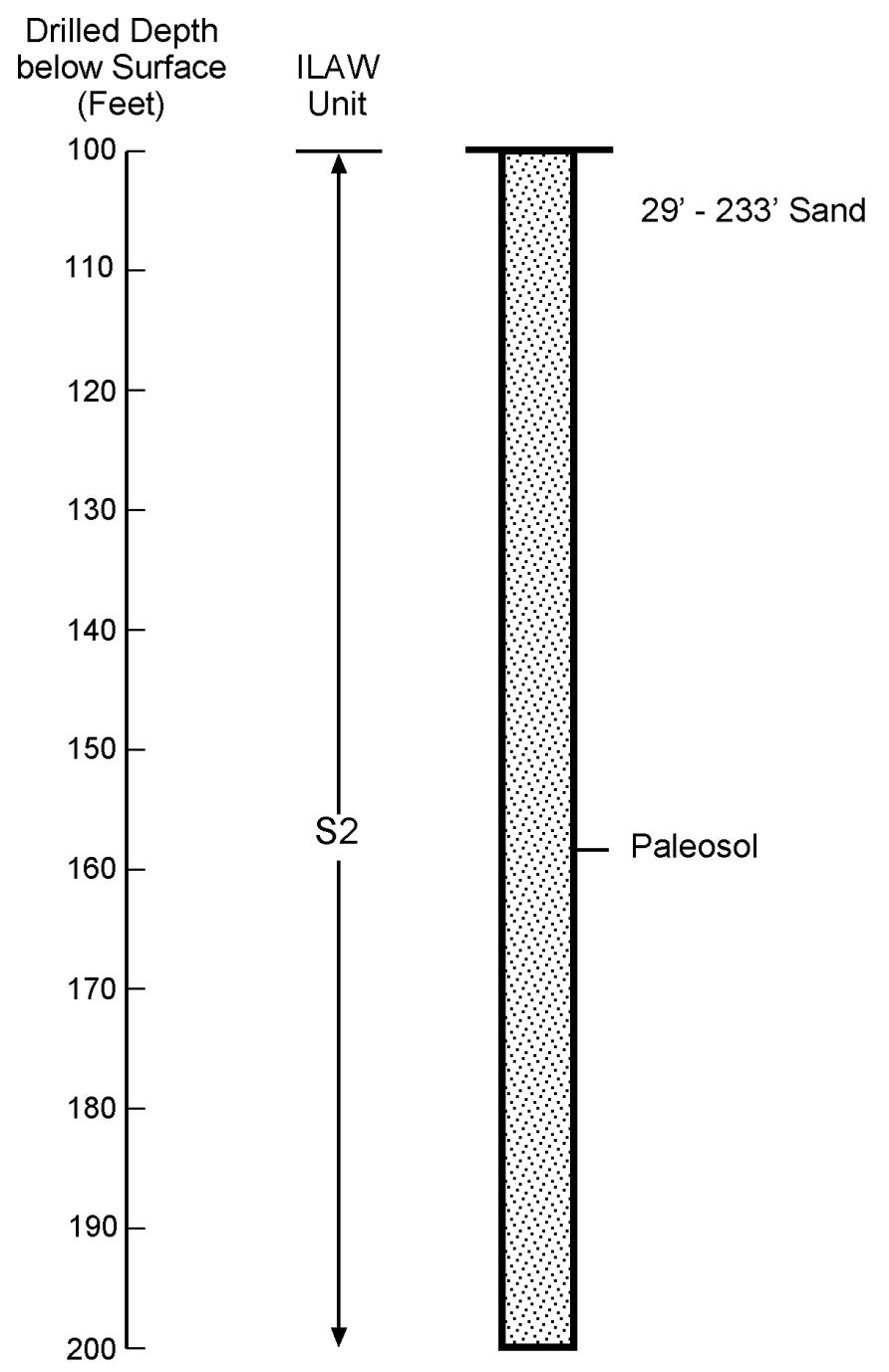

\begin{tabular}{|c|c|c|c|}
\hline 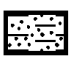 & Sandy Silt to Silty Sand & 0 & Sandy Grave \\
\hline & Sand & & Gravel \\
\hline & $\begin{array}{l}\text { Slightly Gravelly to } \\
\text { Gravelly Sand }\end{array}$ & & \\
\hline
\end{tabular}

G02080026.2b

Figure 5. (contd) 


\section{C3827 (299-E17-23)}

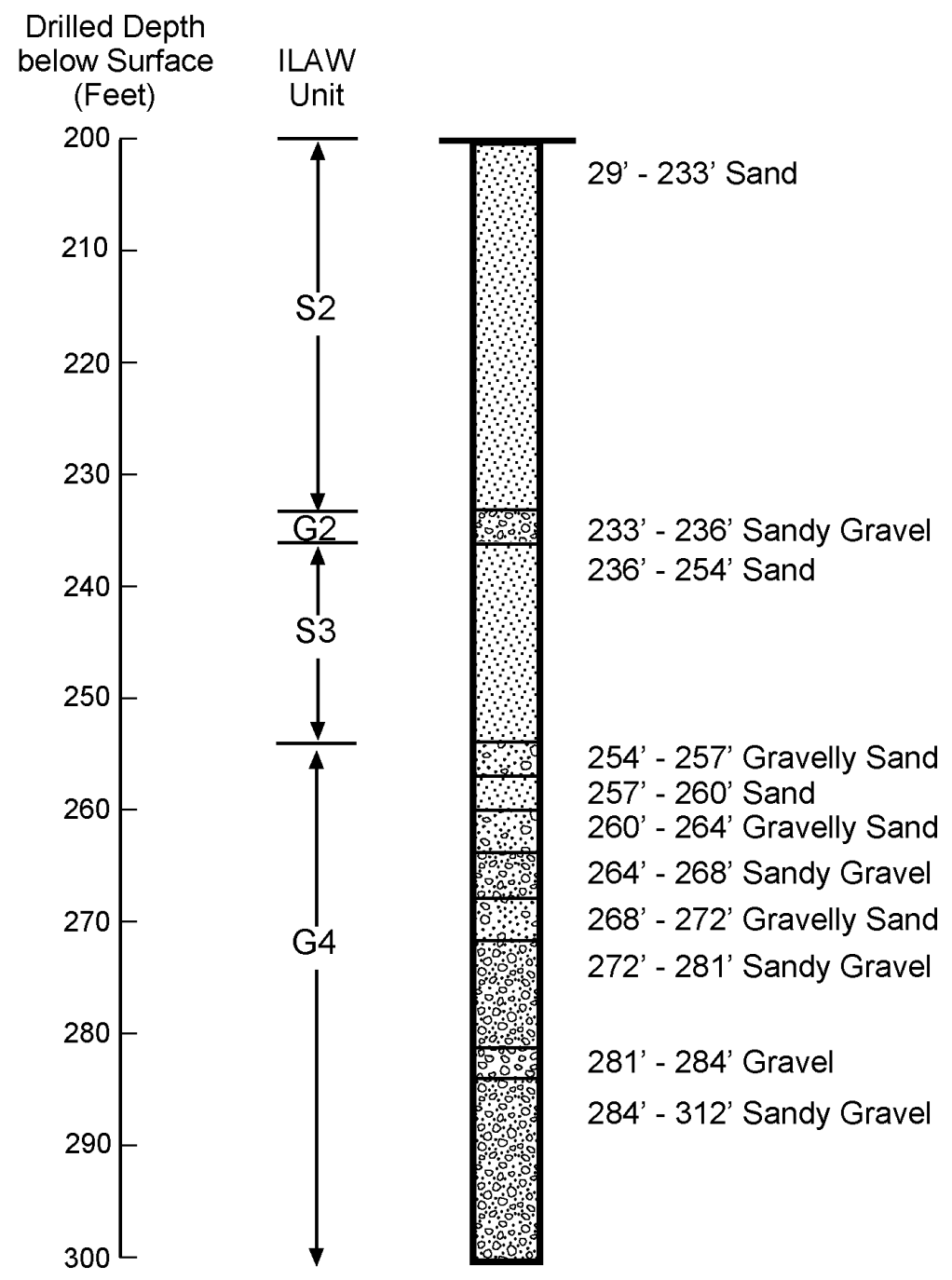

\section{Sandy Silt to Silty Sand \\ 3 Sand Gravel \\ Slightly Gravelly to
Gravelly Sand}

G02080026 2c

Figure 5. (contd) 


\section{C3827 (299-E17-23)}

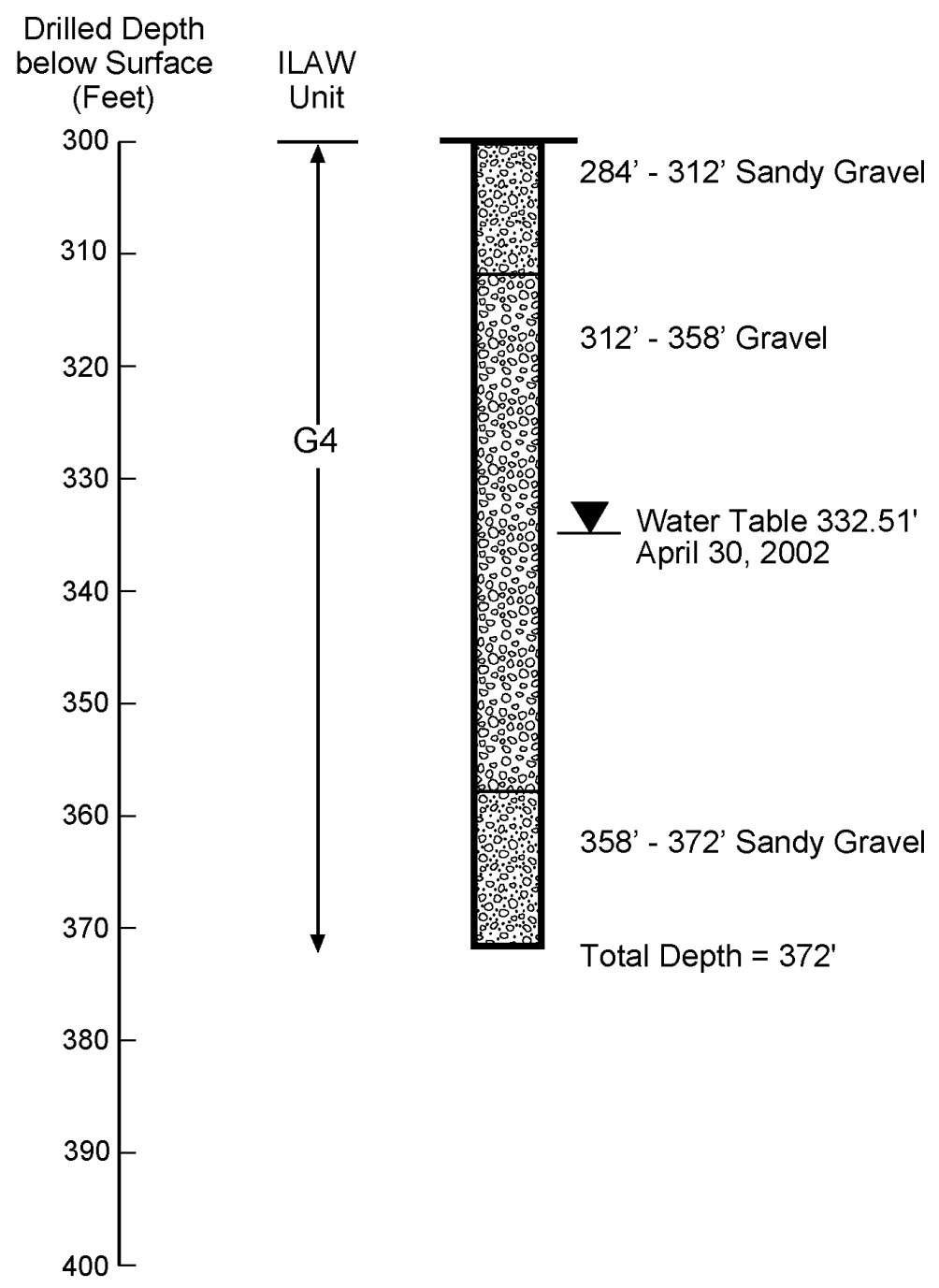

\begin{tabular}{|c|c|c|}
\hline$\because$ & Sandy Silt to Silty Sand & Sandy Gravel \\
\hline n & Sand & 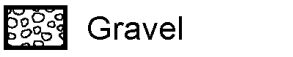 \\
\hline @is & $\begin{array}{l}\text { Slightly Gravelly to } \\
\text { Gravelly Sand }\end{array}$ & $\boldsymbol{\nabla}$ Water Table \\
\hline
\end{tabular}

G02080026.2d

Figure 5. (contd) 


\section{C3828}

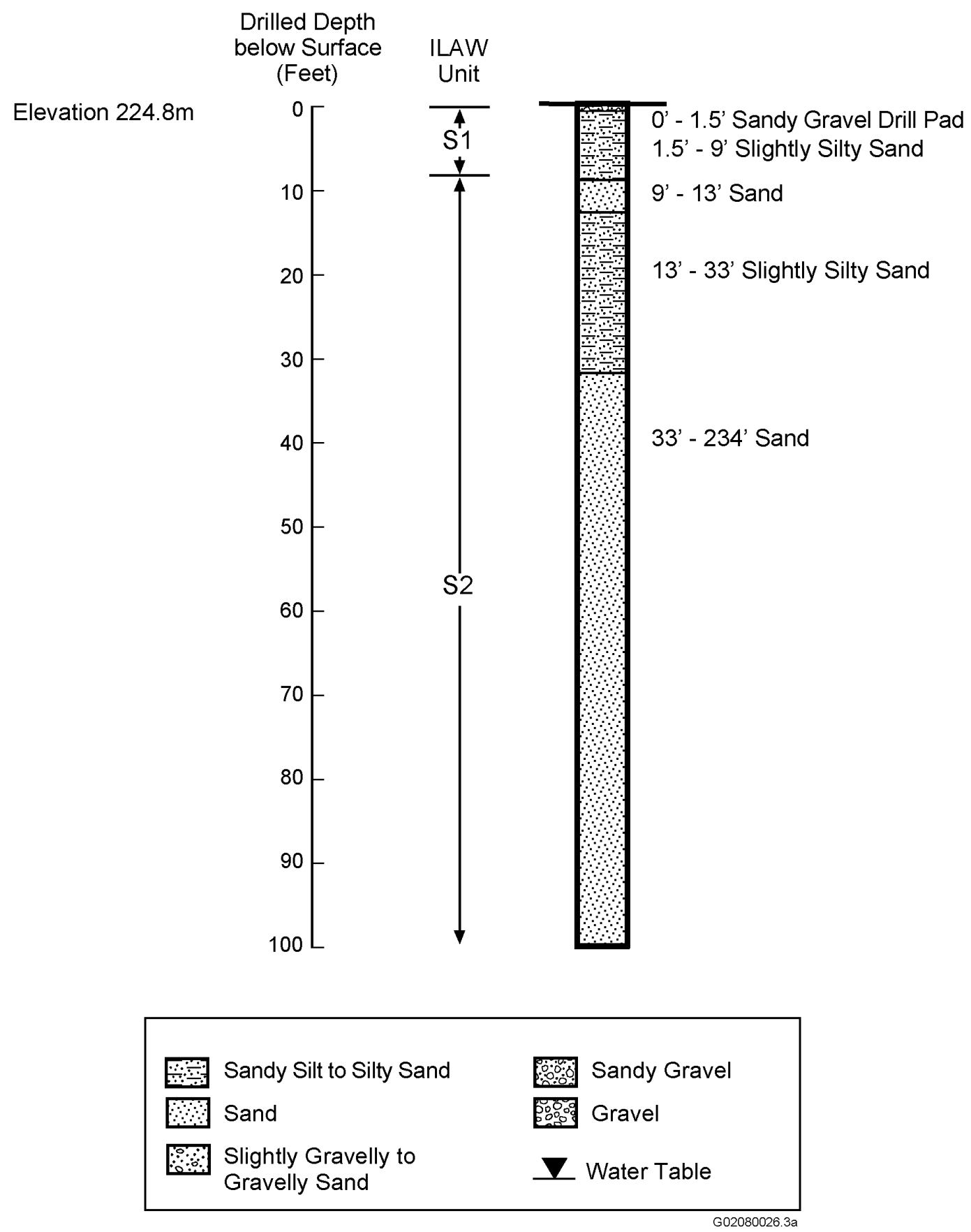

Figure 6. Summary of the Stratigraphy and Lithology of Borehole C3828.

ILAW units refers to sand layers (S) and gravel layers $(\mathrm{G})$ previously observed at the ILAW site. Also see Figure 3. 


\section{C3828}

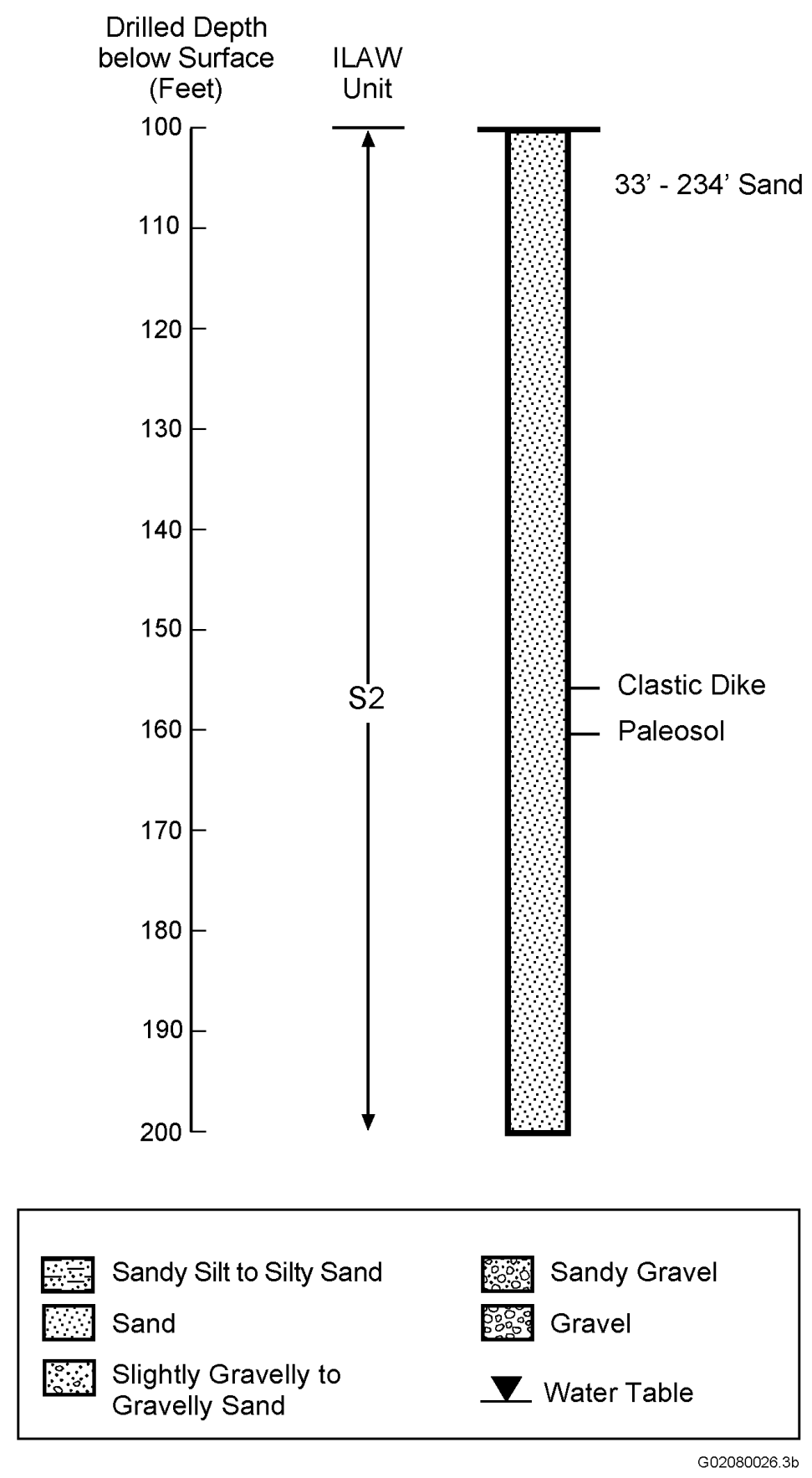

Figure 6. (contd) 


\section{C3828}

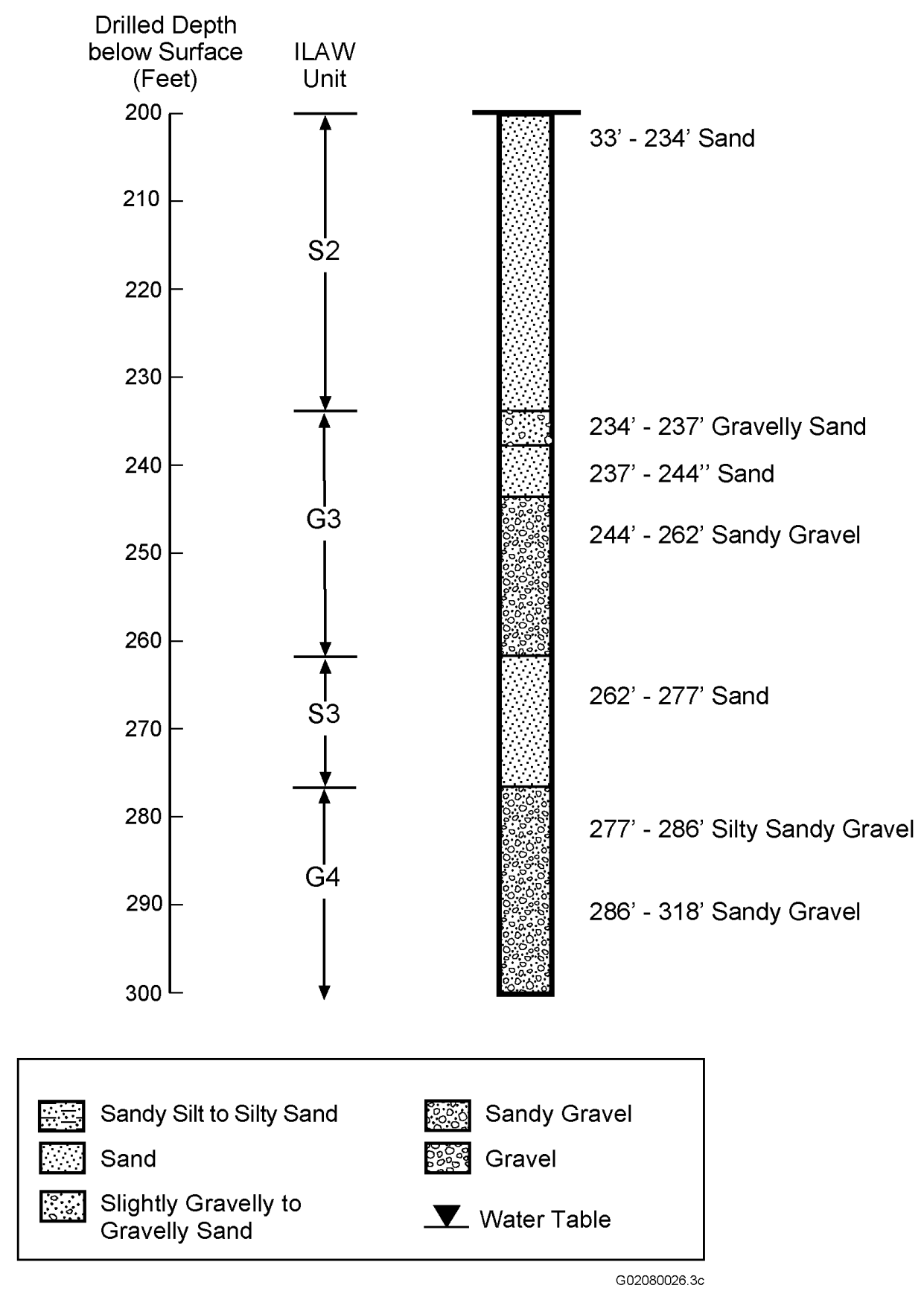

Figure 6. (contd) 


\section{C3828}

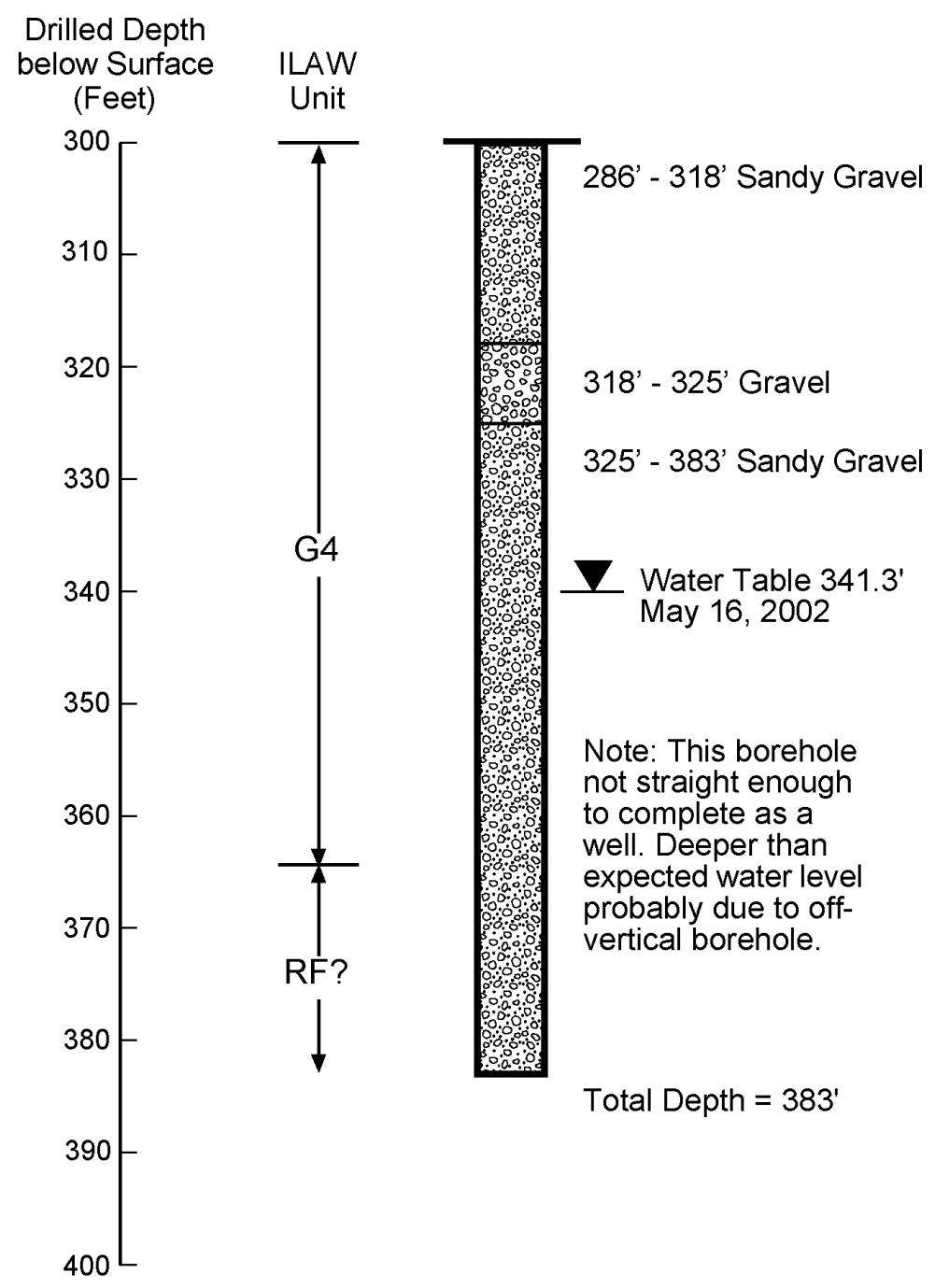

\begin{tabular}{|c|c|}
\hline Sandy Silt to Silty Sand & Sandy Gravel \\
\hline Sand & 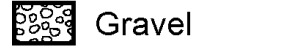 \\
\hline $\begin{array}{l}\text { Slightly Gravelly to } \\
\text { Gravelly Sand }\end{array}$ & $\nabla$ Water Table \\
\hline
\end{tabular}

G02080026.3d

Figure 6. (contd) 


\section{C3926 (299-E17-25)}

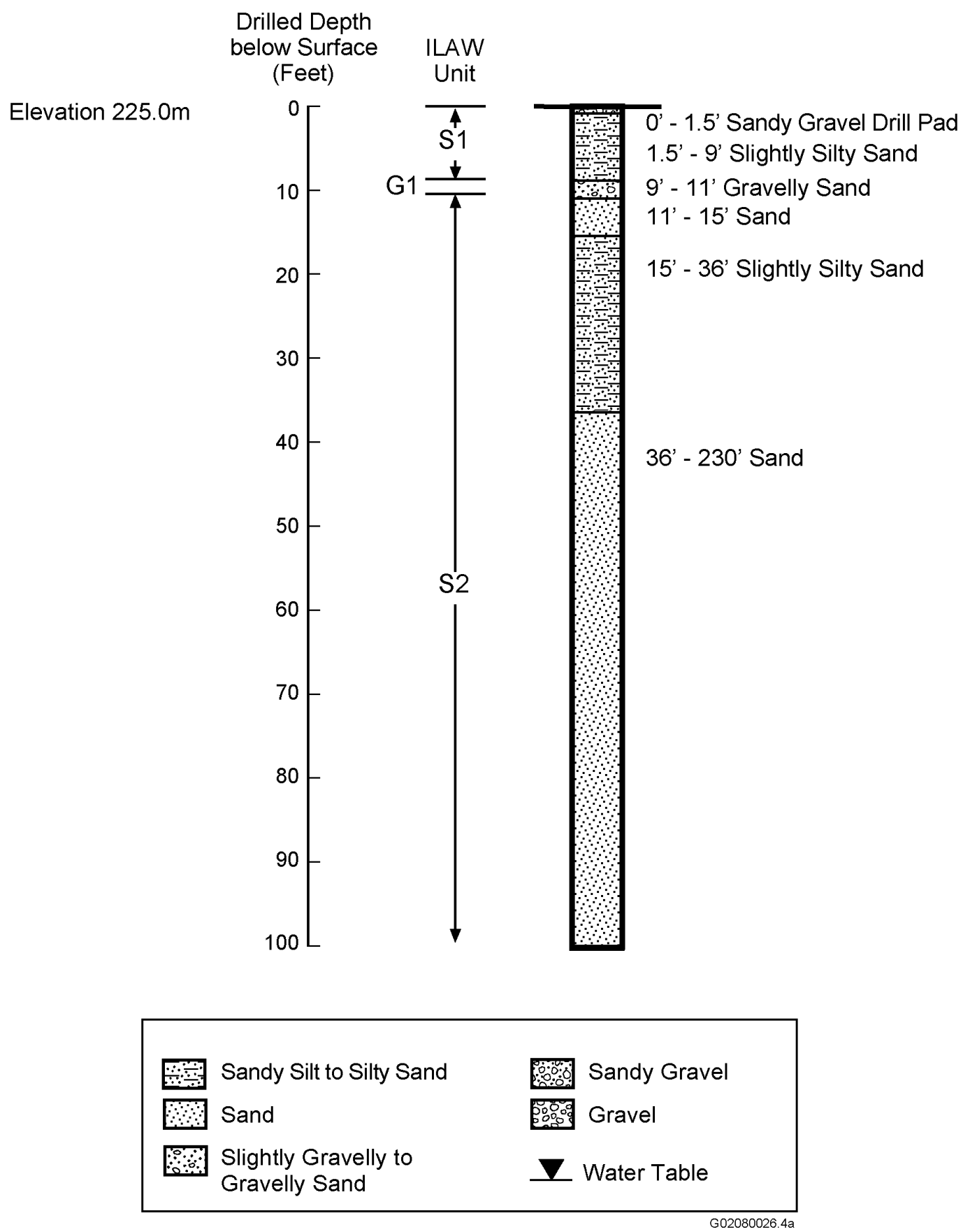

Figure 7. Summary of the Stratigraphy and Lithology of Borehole C3926.

ILAW units refers to sand layers (S) and gravel layers (G) previously observed at the ILAW site. Also see Figure 3. 
C3826 (299-E17-25)

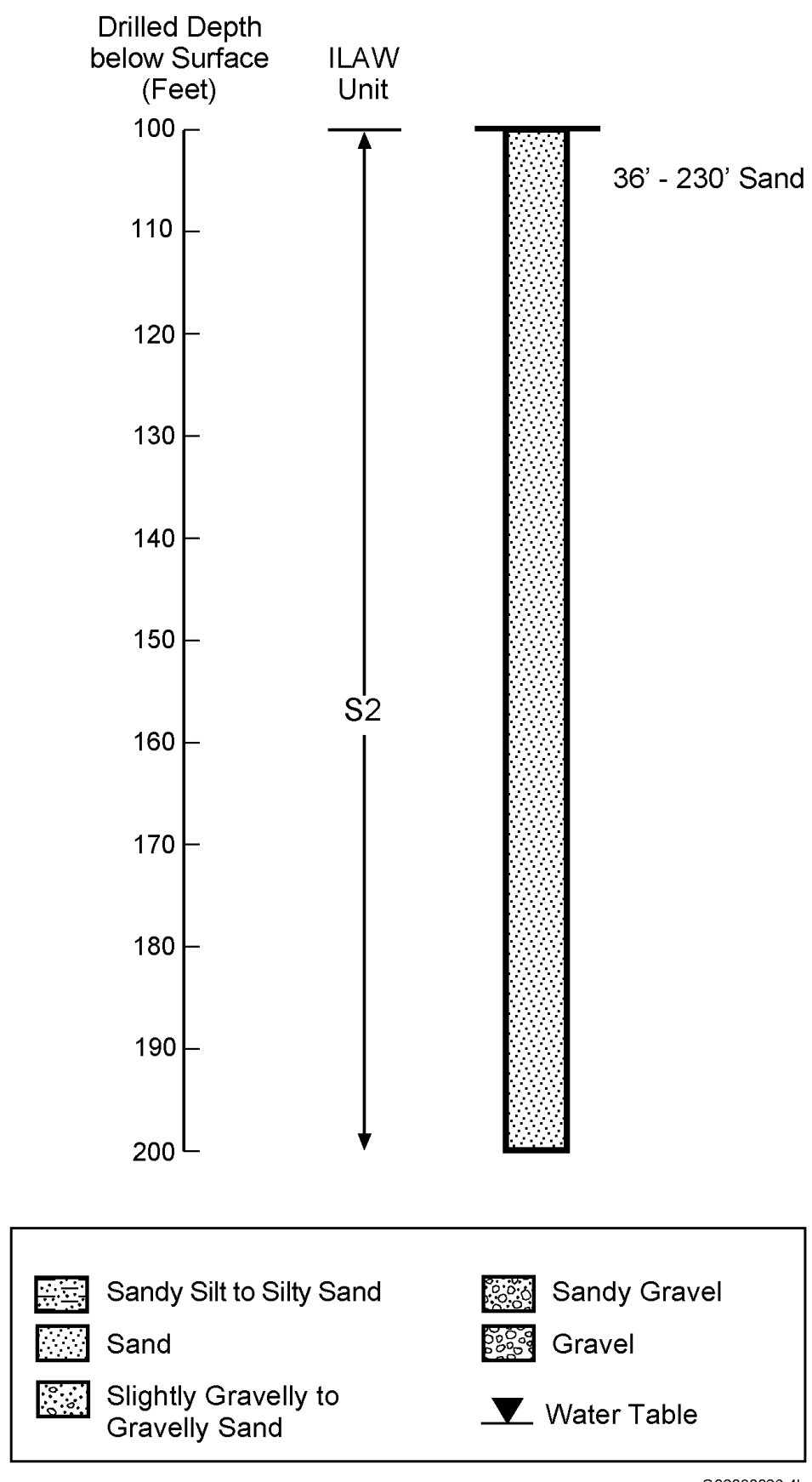

Figure 7. (contd) 


\section{C3826 (299-E17-25)}

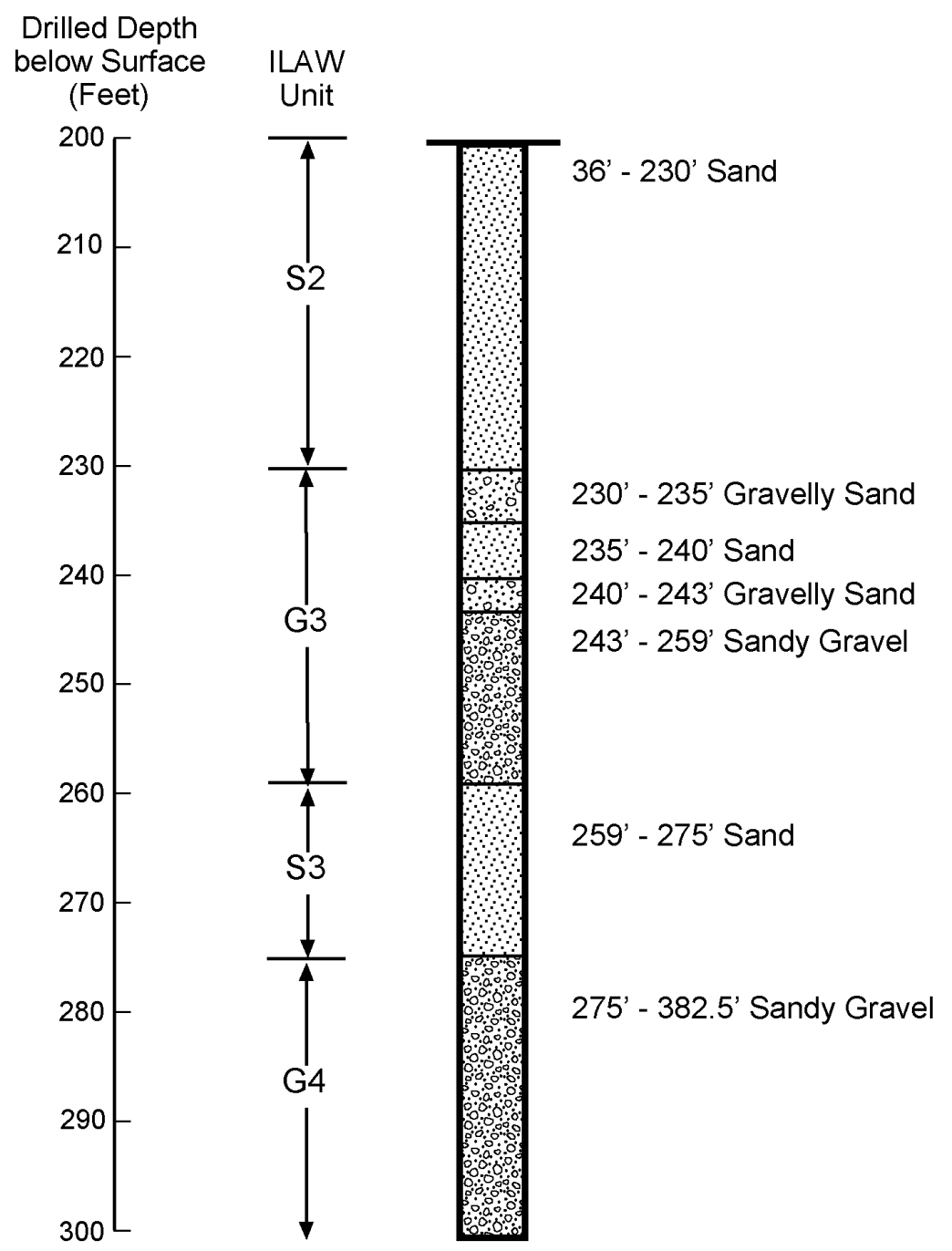

\section{Sandy Silt to Silty Sand Sandy Gravel \\ Sand $\quad$ Gravel \\ Slightly Gravelly to
Gravelly Sand}

G02080026.4C

Figure 7. (contd) 


\section{C3826 (299-E17-25)}

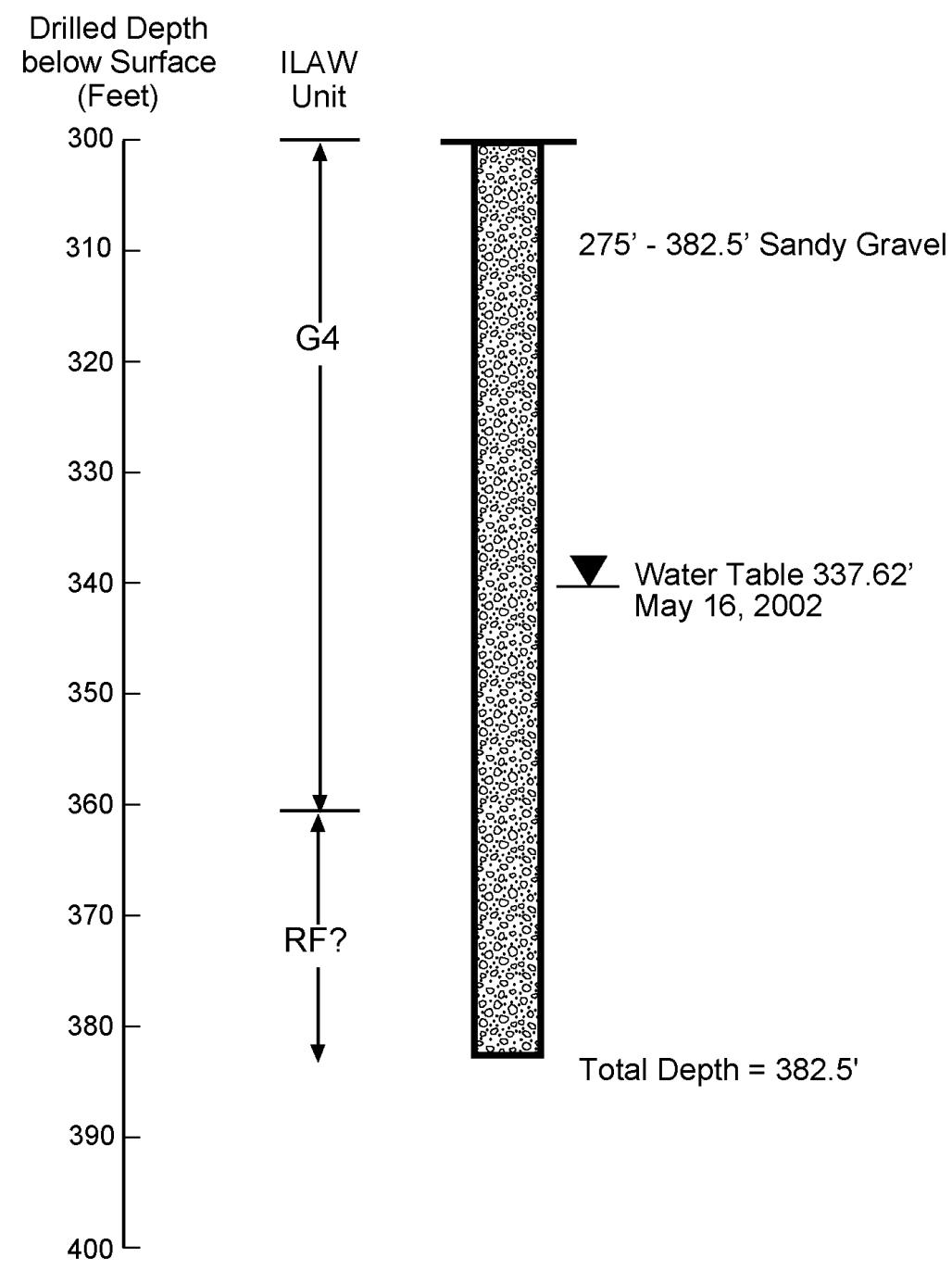

\begin{tabular}{|c|c|c|}
\hline 3 & Sandy Silt to Silty Sand & Sandy Gravel \\
\hline 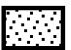 & Sand & [0ㅁ영 Gravel \\
\hline & $\begin{array}{l}\text { Slightly Gravelly to } \\
\text { Gravelly Sand }\end{array}$ & 7 \\
\hline
\end{tabular}

G02080026 4

Figure 7. (contd) 
Table 4. Thickness and Depth of the Hanford Formation Encountered in Boreholes

\begin{tabular}{||c|c|c|c|c||}
\hline \hline Borehole & $\begin{array}{c}\text { Top of Hanford } \\
\text { Formation (ft bgs) }\end{array}$ & $\begin{array}{c}\text { Base of Hanford } \\
\text { Formation (ft bgs) }\end{array}$ & $\begin{array}{c}\text { Thickness of Hanford } \\
\text { Formation (ft) }\end{array}$ & $\begin{array}{c}\text { Thickness of Ringold } \\
\text { Formation (ft) }\end{array}$ \\
\hline \hline C3826 & 0 & $>363(\mathrm{TD})$ & $>363$ & Not Known. \\
\hline C3827 & 0 & $>372(\mathrm{TD})$ & $>372$ & Not Known. \\
\hline C3828 & 0 & $\sim 365$ & $\sim 365$ & $>18$ \\
\hline C3926 & 0 & $\sim 360$ & $\sim 360$ & $>22.5$ \\
\hline
\end{tabular}

\subsubsection{Lower Gravel Sequence}

A basal conglomerate (Figure 8) is present in all four boreholes (G4 in Table 5; Reidel and Horton 2000). This is consistent with the first and second ILAW boreholes (299-E17-21 and 299-E24-21, respectively). The upper part of the conglomerate consists of sandy gravel with very minor silt. The gravel content increases with depth, reaching 80 to $100 \%$ near the bottom of the boreholes. In boreholes C3826 and C3827, the lowermost gravel encountered was an open-framework, medium to coarse pebble (with some cobble) gravel. The open-framework texture was recognized by the field geologist and reflected during drilling, when air used to expel the drill cuttings from the borehole quickly dissipated into the formation.

This lower gravel sequence is equivalent to unit $\mathrm{H} 3$ of Lindsey et al. (1994), mapping unit Qfg 1 , Missoula Outburst flood gravel deposits, of Reidel and Fecht (1994a, b), and the gravel-dominated facies association (GD) of the Hanford formation of DOE (2002).

\subsubsection{Sand Sequence}

Most of the Hanford formation encountered in the boreholes consists dominantly of fine- to coarsegrained sand with traces of silt and fine gravel (S2 and S3 in Table 5) (Figure 9). Within this sequence is a zone (G3) of gravelly sand and sandy gravel between depths of approximately 230 and $260 \mathrm{ft}$ bgs in boreholes C3828 and C3926; this zone is thinner in boreholes C3826 and C3827. In boreholes C3827 and C3926, the sand sequence in these boreholes is topped by gravelly sand (G1) up to $2 \mathrm{ft}$ thick.

This sand sequence is equivalent to unit H2 of Lindsey et al. (1994) and the following mapping units of Reidel and Fecht (1994a, b): Qfs 1 , Qfs 2 , and Qfs $s_{3}$, Missoula Outburst Flood Deposits consisting of sand, silt, and clay. This sequence is also equivalent to the sand-dominated facies association (SD), and the uppermost part of the sequence is equivalent to the interbedded sand- to silt-dominated facies association (ISSD), of the Hanford formation of DOE (2002).

The sands range in composition from about $30 \%$ basaltic and $70 \%$ felsic to $70 \%$ basaltic and $30 \%$ felsic. Generally, the more basaltic-rich sands are deeper than the felsic-rich sands. The sands are generally subrounded to subangular and moderately to well sorted. The degree of compaction varies within the sand-dominated sequence with some samples being loose, uncompacted sediment and others 


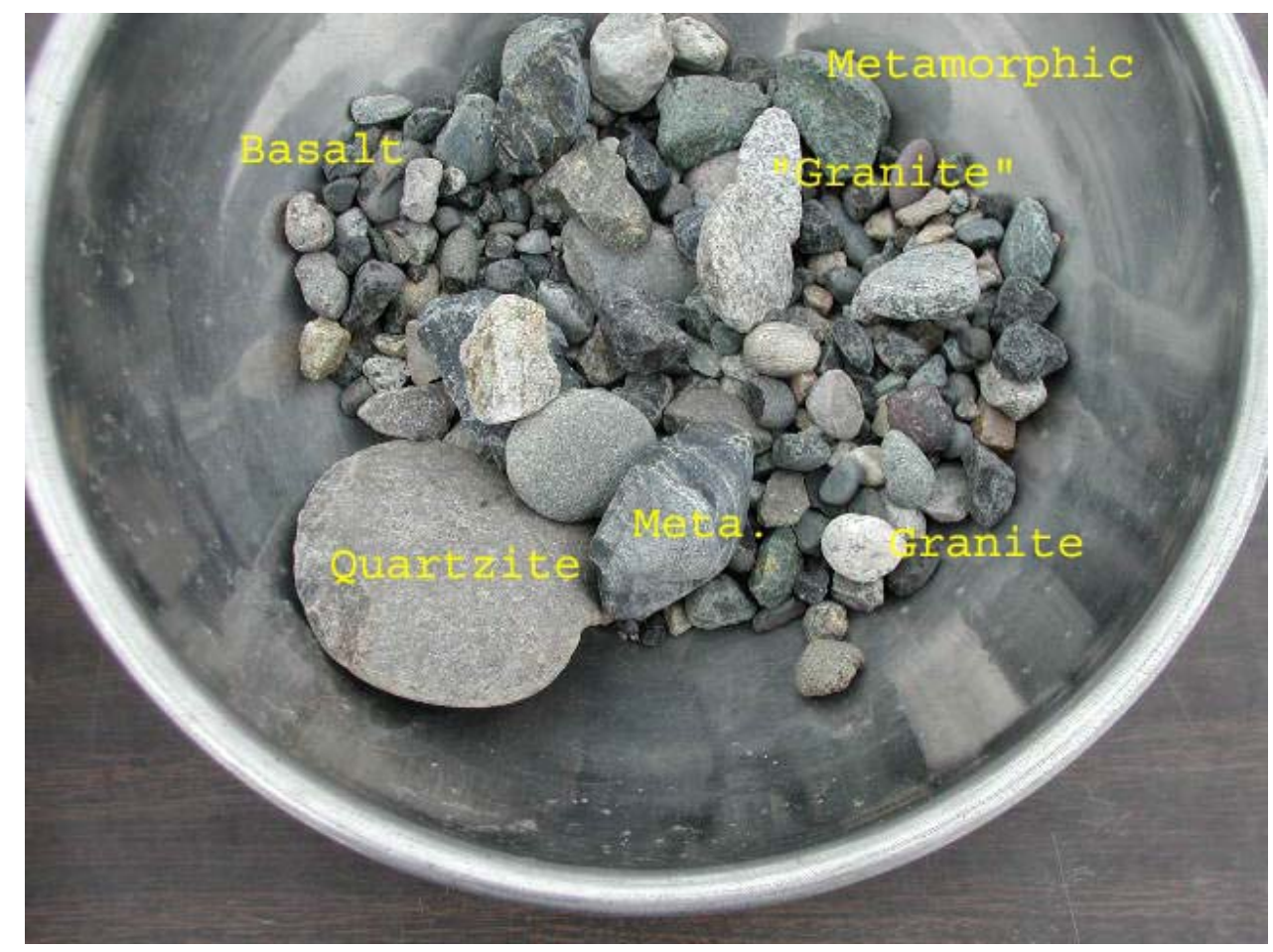

Figure 8. Basal Gravel from Borehole C3826 at the ILAW Site

Table 5. Summary of the Geology and Lithology of Boreholes C3826, C3827, C3828, and C3926

\begin{tabular}{|c|c|c|c|c|c|}
\hline \multicolumn{2}{|c|}{ Hanford Units } & \multirow{2}{*}{$\begin{array}{l}\text { Borehole } \\
\text { C3826 }\end{array}$} & \multirow[b]{2}{*}{ Borehole C3827 } & \multirow{2}{*}{$\begin{array}{l}\text { Borehole } \\
\text { C3828 }\end{array}$} & \multirow{2}{*}{$\begin{array}{l}\text { Borehole } \\
\text { C3926 }\end{array}$} \\
\hline DOE 2002 & ILAW Units & & & & \\
\hline ISSD & S1 & $0^{\prime}$ to $6^{\prime}$ & $0^{\prime}$ to $23^{\prime}$ & $0^{\prime}$ to $9^{\prime}$ & $0^{\prime}$ to $9^{\prime}$ \\
\hline GD & G1 & Not present & $23^{\prime}$ to $29^{\prime}$ & Not present & $9^{\prime}$ to $11^{\prime}$ \\
\hline SD & S2 & $6^{\prime}$ to $216^{\prime}$ & $29^{\prime}$ to $233^{\prime}$ & 9' to $234^{\prime}$ & $11^{\prime}$ to $230^{\prime}$ \\
\hline GD & G3 & $216^{\prime}$ to $238^{\prime}$ & $23^{\prime}$ to $236^{\prime}$ & $234^{\prime}$ to $262^{\prime}$ & $230^{\prime}$ to $259^{\prime}$ \\
\hline SD & $\mathrm{S} 3$ & $238^{\prime}$ to $274^{\prime}$ & $236^{\prime}$ to $254^{\prime}$ & $262^{\prime}$ to $277^{\prime}$ & $259^{\prime}$ to $275^{\prime}$ \\
\hline GD & G4 & $\begin{array}{l}274^{\prime} \text { to } 363^{\prime} \\
\text { (TD) }\end{array}$ & $254^{\prime}$ to $372^{\prime}$ (TD) & $\begin{array}{l}277^{\prime} \text { to } 383^{\prime} \\
\text { (TD) }\end{array}$ & $\begin{array}{l}275^{\prime} \text { to } 382.5^{\prime} \\
\text { (TD) }\end{array}$ \\
\hline $\begin{array}{l}\text { Not } \\
\text { Applicable }\end{array}$ & $\begin{array}{l}\text { Paleosol horizons } \\
\text { recognized }\end{array}$ & $\begin{array}{l}30 \text { '6" to } \\
30 ' 10^{\prime \prime} \\
73 \text { 'to } 73 \text { '4", } \\
768^{\prime \prime} \text { " to } \\
77^{\prime} 3^{\prime \prime}\end{array}$ & $\begin{array}{l}62^{\prime} 6^{\prime \prime} \text { to } 62^{\prime} 8^{\prime \prime} \text { and } \\
158^{\prime} 1.6^{\prime} \text { to } 158^{\prime} 5.2^{\prime \prime}\end{array}$ & $\begin{array}{l}161^{\prime} 5.7 " \text { " to } \\
161^{\prime} 9.7 "\end{array}$ & \\
\hline
\end{tabular}




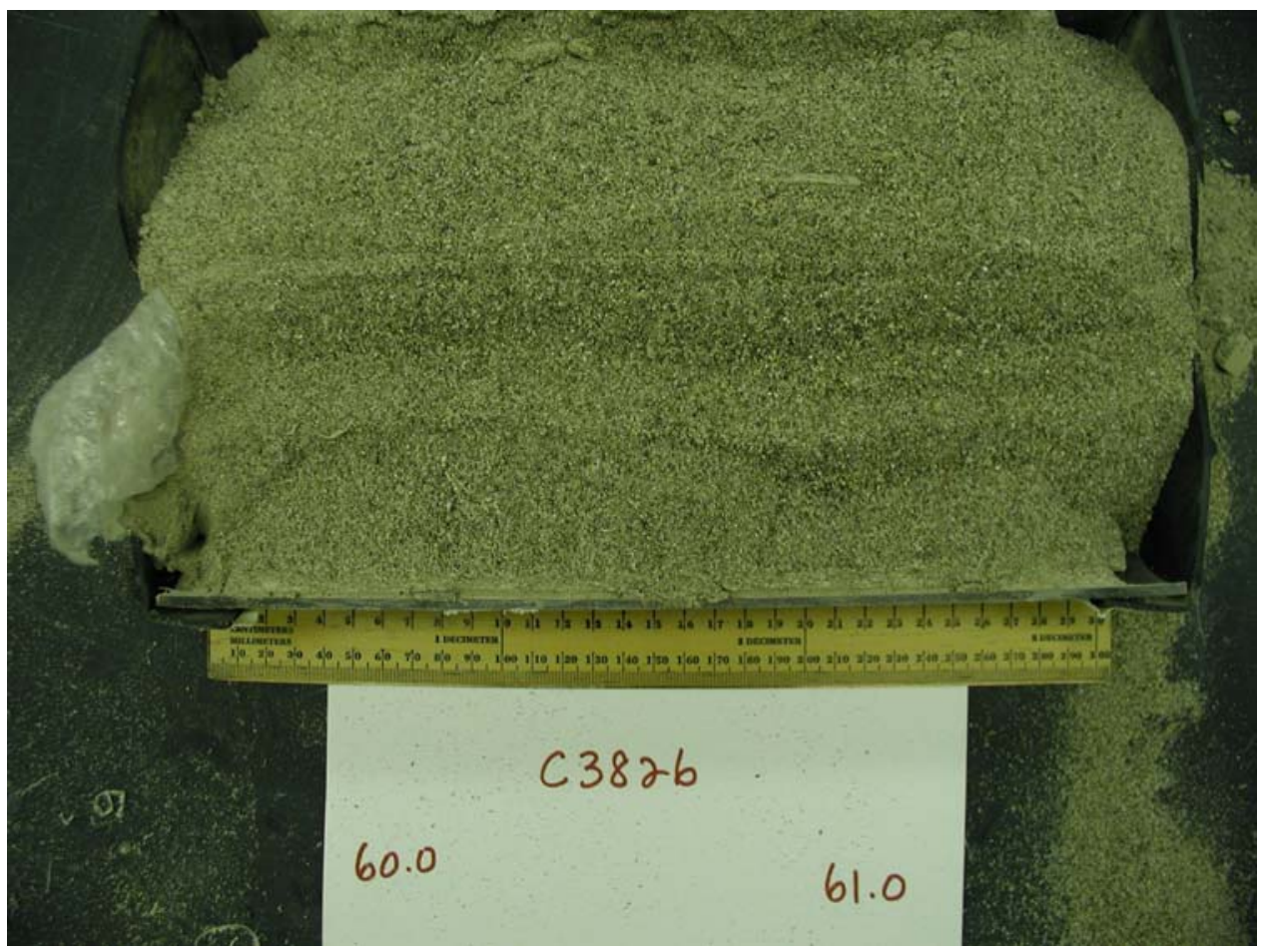

Figure 9. Sand-Dominated Unit from Borehole C3826, 60.0-61.0 Feet, at the ILAW Site

being compacted, competent sediment. The part of the sand-dominated sequence below the sandy gravel (S3) is generally more compact than the sands above the sandy gravel zone. Cementation is rare throughout the sand-dominated sequence, except at paleosols.

The dominant sedimentary feature of the sand-dominated sequence is bedding. Generally, bedding is fairly subtle and is defined by slight color changes (due to slight changes in composition) or changes in grain size. The S3 sands are generally coarser. Bedding defined by grain size changes reflects upwardfining sequences generally 2 to 4 in. $(5$ to $10 \mathrm{~cm})$ thick.

\subsubsection{Paleosols}

Paleosols, or ancient soil zones, are generally calcite-cemented (caliche), bioturbated and apparently leached soil horizons where encountered. At least three paleosol horizons are identified in the drill core from these boreholes (Table 5). The first is encountered at about 30'6" bgs (Figure 10) in boreholes C3826 and C3926. A second, deeper paleosol was encountered in C3827 at a depth of about 62' 6" bgs. Apparent paleosols, one of which may correlate to the deeper paleosol in C3827, were encountered at 73' bgs and 76' '" bgs in borehole C3826. A third paleosol was encountered at a depth of about 160' bgs in boreholes C3827 and 155' in C3828 (Table 5). In general, these paleosols are between 2 and 4 in. (5 to $10 \mathrm{~cm}$ ) thick and may correlate with paleosols identified in the first and second ILAW boreholes (299-E17-21 and 299-E24-21). 


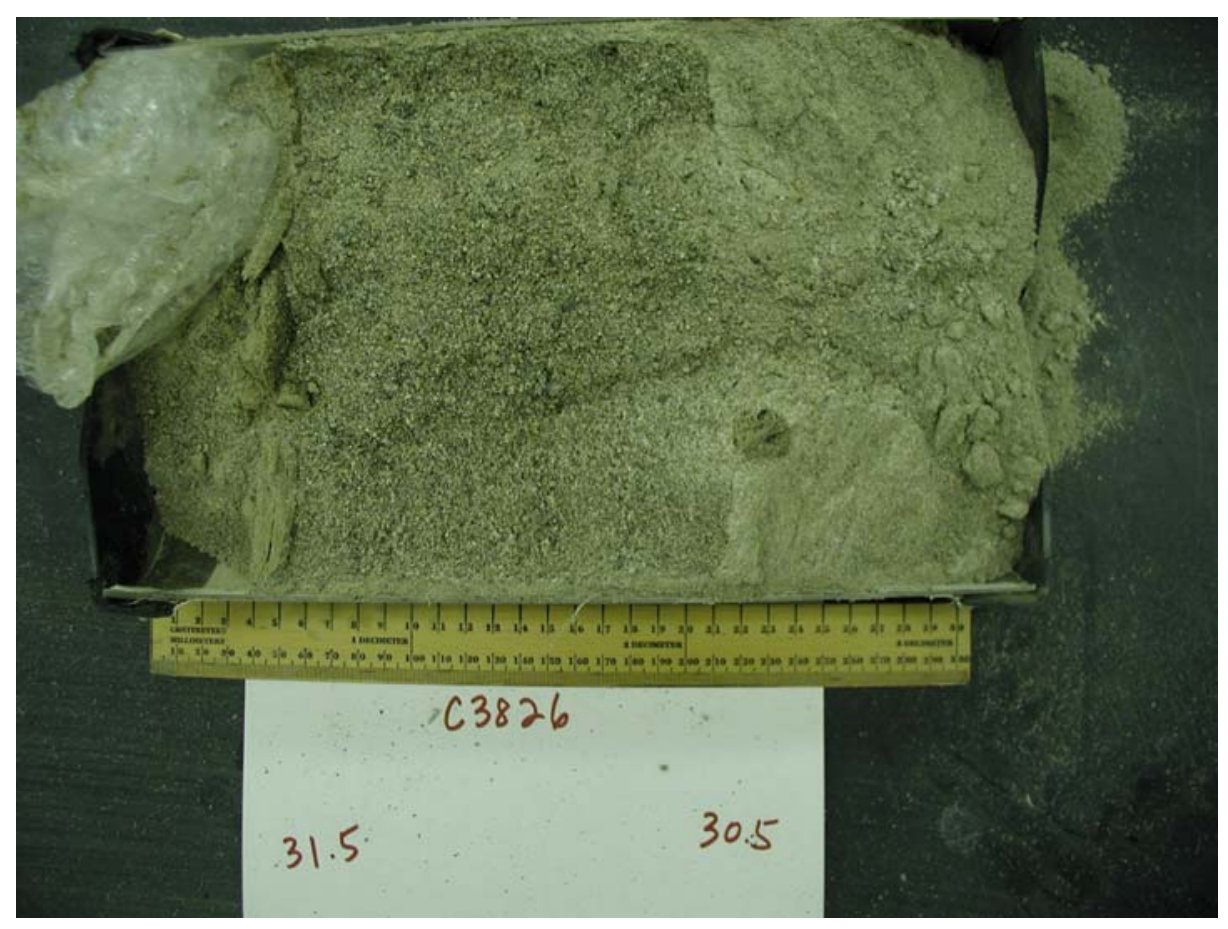

Figure 10. Paleosol from Borehole C3826, Depth 30.5-31.5 Feet. Paleosol is the light colored zone beginning at 30.5 feet.

\subsubsection{Clastic Dikes}

The core interval $155^{\prime} 6$ " to $157^{\prime}$ '6" from borehole C3828 contains a clastic dike (Figure 11). A crosssection cut through the core sample reveals a $3 \mathrm{~cm}$-wide dike of very fine to fine sand crosscutting medium-grained sand. The dike is not observed in core samples above 155' and below 158', and its orientation and continuity is unknown.

\subsection{Passive Gamma Spectral Results}

Boreholes 299-E17-22, 299-E17-23, and 299-E17-25 were logged during August 2002 using a spectral gamma ray tool to verify the absence of man-made radionuclides. Previous experience from geophysical logging at 299-E17-21 and 299-E24-21 showed that the vadose zone at the ILAW site does not exhibit significant stratigraphic changes that can be detected during geophysical logging. The results of these surveys are presented in Appendix F. There are four logs: total gamma, potassium-40, uranium-238 and thorium-232. No man-made gamma-emitting contamination was detected. 


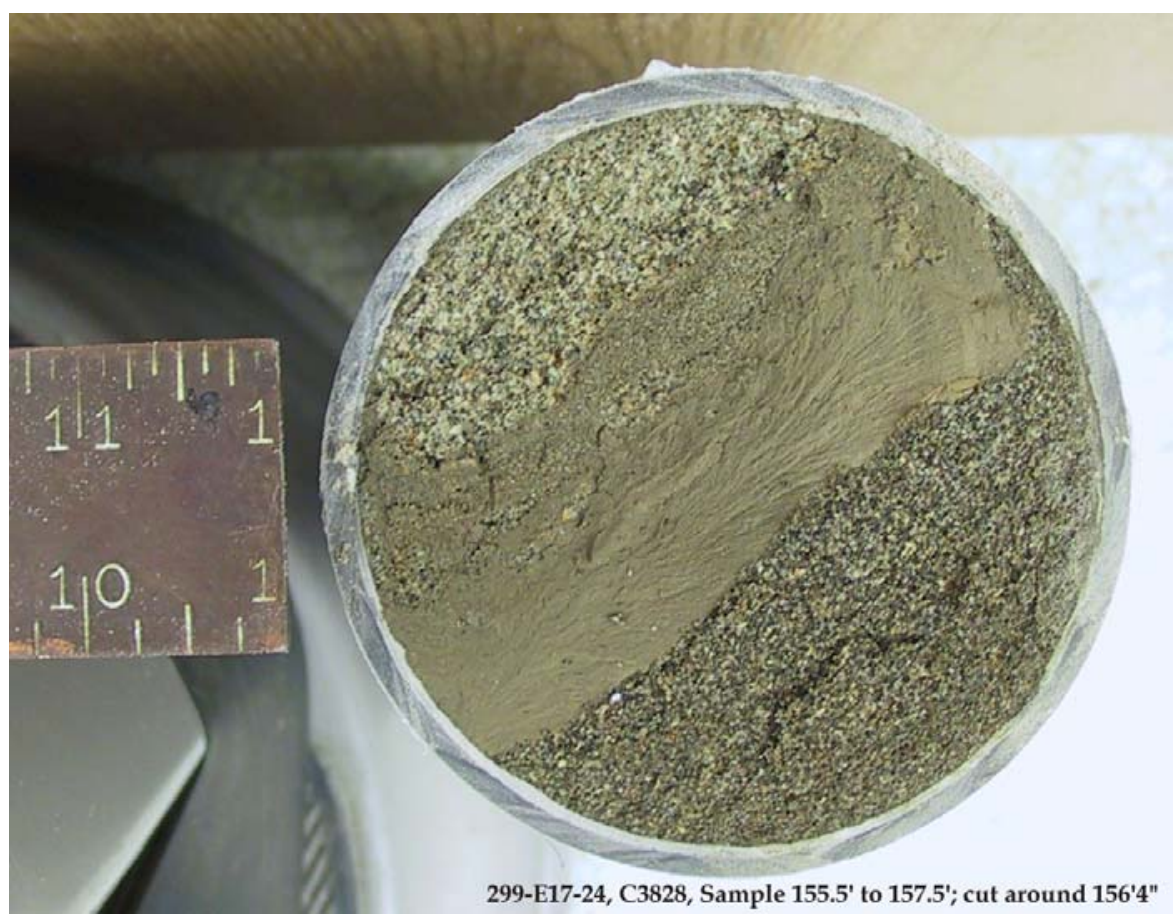

Figure 11. Clastic Dike Penetrated in Borehole C3828

\subsection{Groundwater Chemistry}

A summary of the chemistry of groundwater samples from wells 299-E17-22, 299-E17-23, and 299-E17-25 is given in Table 6. With the exception of sulfate, all values are similar to known Site-wide background levels from DOE (1992). Measured sulfate concentrations are 84.9 and $64.1 \mathrm{mg} / \mathrm{L}$ in wells C3827 and C3926, respectively, notably higher than background. Sulfate levels in background areas range between $30.6 \mathrm{mg} / \mathrm{L}$ and $41.3 \mathrm{mg} / \mathrm{L}$ (DOE 1992). The difference between sulfate levels measured in wells C3827 and C3926 and the background levels appears to be significant.

\subsection{Conclusions}

Results from the FY 2002 ILAW boreholes are consistent with results from the first and second ILAW boreholes (299-E17-21, 299-E24-21, respectively). These results indicates that the ILAW site is situated above an erosional channel, that is cut into the Ringold Formation and filled with unconsolidated, open-framework gravel of the Hanford formation. Stratigraphy above the channel appears to consist of sediments representing at least three individual Lake Missoula cataclysmic flooding events. 
Table 6. Groundwater Chemistry

\begin{tabular}{|c|c|c|c|c|c|c|}
\hline & 299-E17-22 & 299-E17-23 & $299-\mathrm{E} 17-25^{(\mathrm{e})}$ & $\mathrm{PNL}^{(\mathrm{a})}$ & $\mathrm{USGS}^{(\mathrm{b})}$ & $\mathrm{WHC}^{(\mathrm{c})}$ \\
\hline Chloride, $\mathrm{mg} / \mathrm{L}$ & 9.7 & 11.4 & 10.8 & $10.3 \pm 6.5$ & $12.2 \pm 7.8$ & $8.8 \pm 7.7$ \\
\hline Fluoride, $\mathrm{mg} / \mathrm{L}$ & 0.43 & 0.57 & 0.49 & $0.37 \pm 0.1$ & $0.55 \pm 0.33$ & $0.44 \pm 0.13$ \\
\hline Nitrate, mg/L & 4.1 & 4.5 & 6.9 & NA & $3.2 \pm 3.4$ & $5.2 \pm 3.6$ \\
\hline Sulfate, $\mathrm{mg} / \mathrm{L}$ & 37.5 & 84.9 & 64.1 & $34.4 \pm 16.9$ & $41.3 \pm 27.9$ & $30.6 \pm 22.6$ \\
\hline Tritium, pCi/L & $12,600 \pm 840^{(\mathrm{d})}$ & $4,000 \pm 430$ & $66,900 \pm 3100$ & NA & NA & NA \\
\hline \multicolumn{7}{|c|}{$\begin{array}{l}\text { (a) From PNL-6886 (Evans et al. 1989) and DOE (1992). } \\
\text { (b) Compiled by the U.S. Geological Survey from Hanford Site area sources in the National Water Information System } \\
\text { database; from DOE (1992). } \\
\text { (c) Based on } 7 \text { wells located in the background area upgradient of Hanford facilities or in the southern part of the site; from } \\
\text { DOE (1992). } \\
\text { (d) Total uncertainty ( } 2 \sigma) \text {. } \\
\text { (e) When planning for sampling, borehole C3828 (299-E17-24) was originally planned as the groundwater monitoring well and } \\
\text { labels were prepared. When it was determined to abandon C3828 and offset drill C3926 (299-E17-25), the sampling labels } \\
\text { were not changed but the correction was noted in the drilling activity logs. }\end{array}$} \\
\hline
\end{tabular}

\subsection{References}

Delaney, C. D., K. A. Lindsey, and S. P. Reidel. 1991. Geology and Hydrology of the Hanford Site: A Standardized Text for Use in Westinghouse Hanford Company Documents and Reports. WHC-SD-ERTI-003, Rev. 0, Westinghouse Hanford Company, Richland, Washington.

DOE. 1992. Hanford Site Groundwater Background. DOE/RL-93-23, U.S. Department of Energy, Richland, Washington.

DOE. 2002. Standardized Stratigraphic Nomenclature for Post-Ringold-Formation Sediments Within the Central Pasco Basin. DOE/RL-2002-39, U.S. Department of Energy, Richland, Washington.

Evans, J. C., R. W. Bryce, and D. R. Sherwood. 1989. Hanford Site Groundwater Monitoring for January through June 1988. PNL-6886, Pacific Northwest Laboratory, Richland, Washington.

Horton, D. G., S. P. Reidel, Yi-Ju Chein, and R. M. Mitchell. 2000. Remote-Handled Low Activity Waste Disposal Facility Per-Operational Monitoring Plan. RPP-6877, CH2M HILL Hanford Group, Richland, Washington.

Lindsey, K. A., S. P. Reidel, K. R. Fecht, J. L. Slate, A. G. Law, and A. M. Tallman. 1994.

Geohydrologic Setting of the Hanford Site, South-Central Washington. In, D. A. Swanson and R. A. Haugerud: Geologic Field Trips in the Pacific Northwest, 1994 Annual Meeting, Geological Society of America, v. 1, p 1C-1-16. 
Mann, F. M., R. J. Puigh, II, S. H. Finfrock, E. J. Freemen, Jr., R. Khaleel, D. H. Bacon, M. P. Bergeron, B. P. McGrail, and S. K. Wurstner. 2001. Hanford Immobilized Low-Activity Waste Performance Assessment: 2001 Version. DOE/ORP-2000-24, Rev. b., U.S. Department of Energy, Office of River Protection, Richland, Washington.

Reidel, S. P., K. A. Lindsey, and K. R. Fecht. 1992. Field Trip Guide to the Hanford Site. WHC-MR0391, Westinghouse Hanford Company, Richland, Washington.

Reidel, S. P., A. M. Tallman, V. G. Johnson, C. J. Chou, and S. M. Narbutovskih. 1995.

Characterization Plan for the Proposed TWRS Treatment Complex. WHC-SD-WM-PNL-109, Westinghouse Hanford Company, Richland, Washington.

Reidel, S. P., D. G. Horton, and M. M. Valenta. 2001. Geologic and Wireline Borehole Summary from the Second ILAW Borehole (299-E24-21). PNNL-13652, Pacific Northwest National Laboratory, Richland, Washington.

Reidel, S. P., K. D. Reynolds, and D. G. Horton. 1998. Immobilized Low-Activity Waste Site Borehole 299-E17-21. PNNL-11957, Pacific Northwest National Laboratory, Richland, Washington.

Reidel, S. P. and K. R. Fecht. 1994a. Geologic Map of the Richland 1:100,000 Quadrangle, Washington. Washington Division of Geology and Earth Resources Open File Report 94-8, 21 p., 1 plate.

Reidel, S. P. and K. R. Fecht. 1994b. Geologic Map of the Priest Rapids 1:100,000 Quadrangle, Washington. Washington Division of Geology and Earth Resources Open File Report 94-13, 22p. 1 plate

Reidel, S. P. 2002. Characterization Plan for Fiscal year 2002 Immobilized Low-Activity Waste Site Characterization Boreholes. PNNL-13283-1, Pacific Northwest National Laboratory, Richland, Washington.

Walker, L. D. 2002. Borehole Summary Report: 2002 Low-Activity Waste Site Well Initialization. BHI01647, Bechtel Hanford, Inc., Richland, Washington. 


\section{Appendix A}

\section{Well Summary Report for 2002 ILAW Well Installations}




\section{Appendix A}

A. 1 
$\mathrm{BHI}-01647$

Rev. 0

\section{Well Summary Report: 2002 Immobilized Low-Activity Waste Well Installation}


TRADEMARK DISCLAIMER

Reference herein to any specific commercial product, process, or service by trade name, trademark, manufacturer, or otherwise, does not necessarily constitute or imply its endorsement,

recommendation, or favoring by the United States Government or any agency thereof or its contractors or subcontractors.

This report has been reproduced from the best available copy. Available in paper copy and microfiche.

Available for a processing fee to U.S. Department of Energy and its contractors from:

U.S. Department of Energy

Office of Scientific and Technical Information

P.O. Box 62

Oak Ridge, TN 37831-0062

(865) $576-8401$

fax: (865) 576-5728

email: reports@adonis.osti.gov

online ordering: http://www.doe.gov/bridge

Available for sale to the public, in paper, from:

U.S. Department of Commerce

National Technical Information Service

5285 Port Royal Road

Springfield, VA 22161

(800) 553-6847

fax: (703) 605.6900

email: orders@ntis.fedworld.gov

online ordering: http://www.ntis.gov/ordering.htm

Printed in the United States of America

DISCLM-5.CHP (11/99) 
BHI-01647

Rev. 0

QU: NA

TSP: NRA

ERA: NRA

APPROVAL PAGE

Title: Well Summary Report: 2002 Immobilized Low-Activity Waste Well Installation

Approval: $\quad$ L. R. Curry, Acting Project Manager/Project Engineer Groundwater/Vadose Zone Integration Project

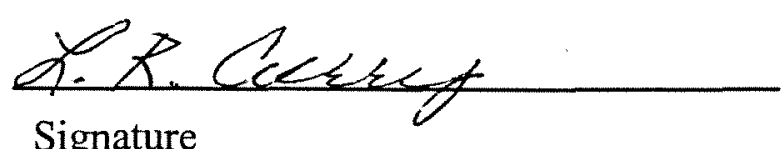

Signature

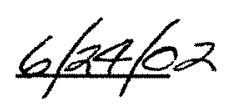

Date

L. M. Dittmer, Project Environmental Lead, . Groundwater/Vadose Zone Integration Project

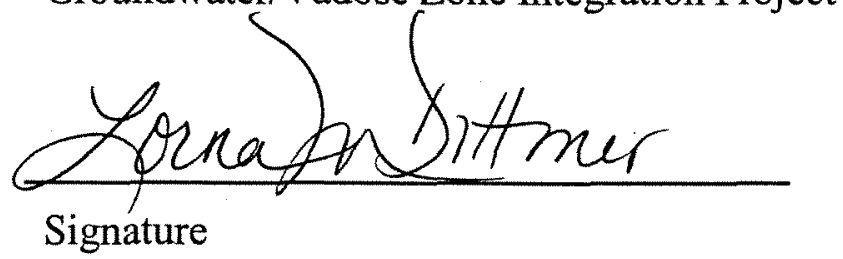

R. L. Jackson, Groundwater Operations Task Lead, Groundwater/Vadose Zone Integration Project
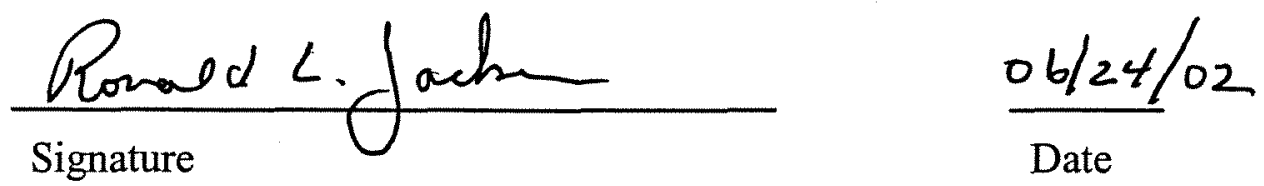

The approval signatures on this page indicate that this document has been authorized for information release to the public through appropriate channels. No other forms or signatures are required to document this information release.

BHI-DIS XUR 6/34/0\% 
BHI-01647

Rev. 0

\section{Well Summary Report: 2002 Immobilized Low-Activity Waste Well Installation}

Authors

L. D. Walker

C. S. Wright

CH2M HILL Hanford, Inc.

Date Published

June 2002 


\section{TABLE OF CONTENTS}

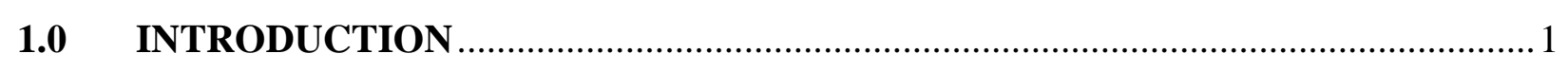

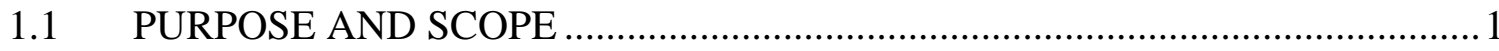

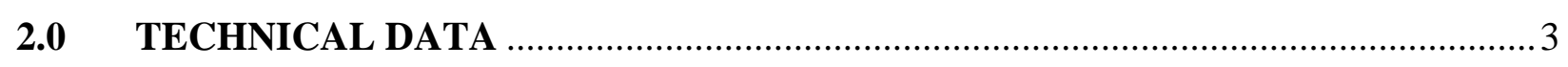

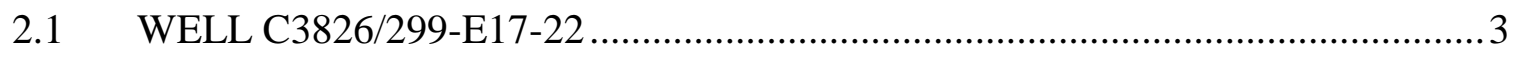

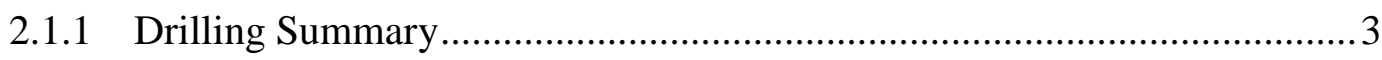

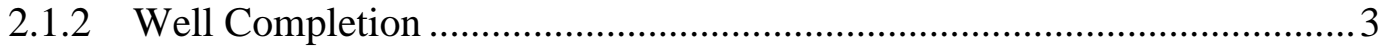

2.1.3 Final Well Development and Pumping Test ........................................ 5

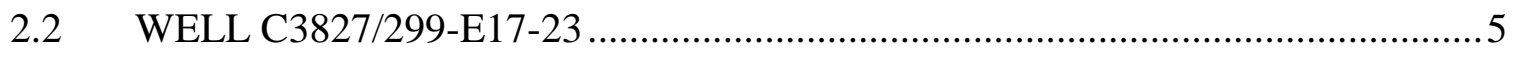

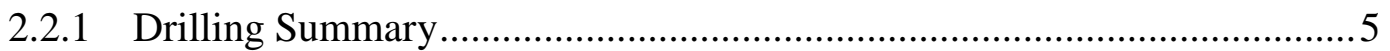

2.2.2 Well Completion .................................................................................. 5

2.2.3 Final Well Development and Pumping Test ...................................... 7

2.3 WELL C3828/299-E17-24 ................................................................... 7

2.3.1 Drilling Summary ........................................................................... 7

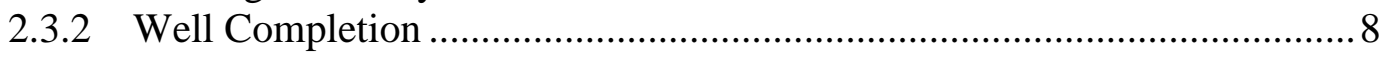

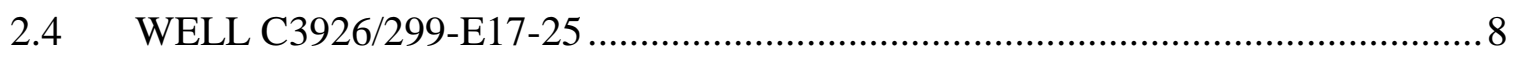

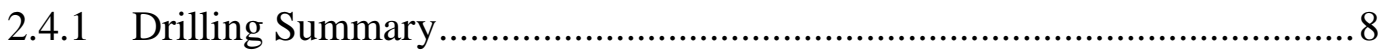

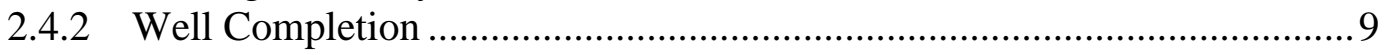

2.5 WASTE MANAGEMENT …...............................................................

2.5.1 Vadose Zone Cuttings ................................................................. 10

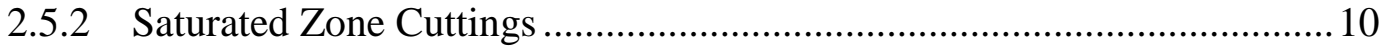

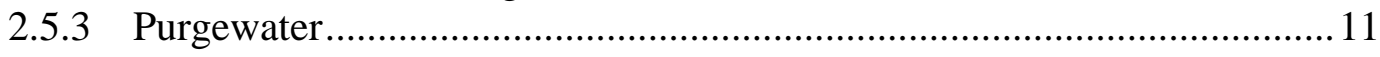

2.6 WELL ACCEPTANCE.......................................................................... 11

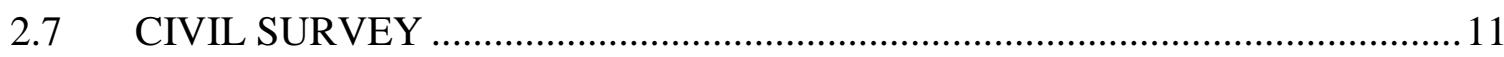

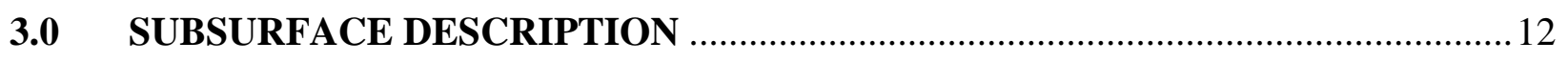

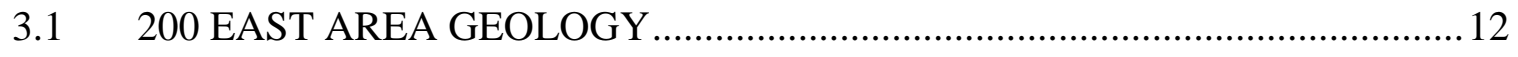

3.1.1 Well C3826/299-E17-22 Borehole Geology ........................................ 12

3.1.2 Well C3827/299-E17-23 Borehole Geology......................................... 12

3.1.3 Well C3828/299-E17-24 Borehole Geology ........................................ 13 
4.0 REFERENCES ....................................................................................................14

\section{APPENDICES}

\begin{tabular}{|c|c|}
\hline A & WELL SUMMARY SHEETS \\
\hline $\mathrm{B}$ & BOREHOLE LOG SHEETS ................. \\
\hline $\mathrm{C}$ & WELL DEVELOPMENT AND TESTING DATA... \\
\hline $\mathrm{D}$ & SURVEY DATA REPORT SHEETS.. \\
\hline
\end{tabular}

\section{FIGURE}

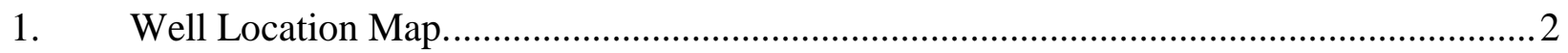

\section{TABLES}

\begin{tabular}{|c|c|}
\hline 1. & 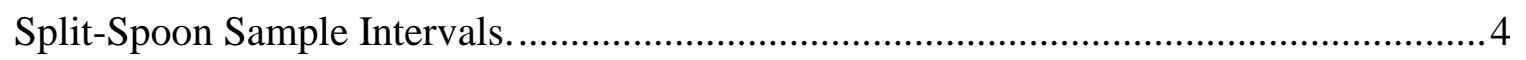 \\
\hline 2. & 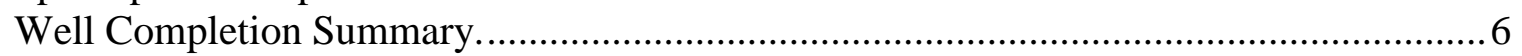 \\
\hline 3. & Well Development Data... \\
\hline 4. & Waste Designation Sample Results, Well C3826 (299-E17-22) .................................... \\
\hline 5. & 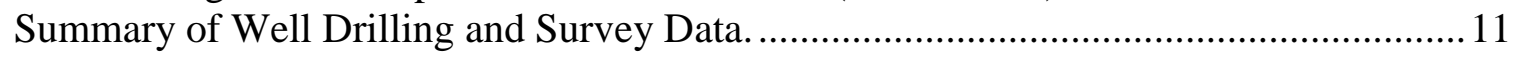 \\
\hline 6. & 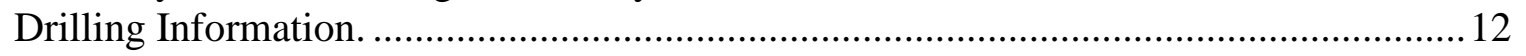 \\
\hline 7. & Pumping Information. .. \\
\hline
\end{tabular}




\section{ACRONYMS}

$\begin{array}{ll}\text { bgs } & \text { below ground surface } \\ \text { DQO } & \text { data quality objective } \\ \text { FY } & \text { fiscal year } \\ \text { ID } & \text { inside diameter } \\ \text { ILAW } & \text { outside diameter } \\ \text { OD } & \text { Pacific Northwest National Laboratory } \\ \text { PNNL } & \text { total depth } \\ \text { TD } & \text { upper confidence limit } \\ \text { UCL } & \text { Washington Administrative Code }\end{array}$




\section{METRIC CONVERSION CHART}

\begin{tabular}{|c|c|c|c|c|c|}
\hline \multicolumn{3}{|c|}{ Into Metric Units } & \multicolumn{3}{|c|}{ Out of Metric Units } \\
\hline If You Know & Multiply By & To Get & If You Know & Multiply By & To Get \\
\hline Length & & & Length & & \\
\hline inches & 25.4 & millimeters & millimeters & 0.039 & inches \\
\hline inches & 2.54 & centimeters & centimeters & 0.394 & inches \\
\hline feet & 0.305 & meters & meters & 3.281 & feet \\
\hline yards & 0.914 & meters & meters & 1.094 & yards \\
\hline miles & 1.609 & kilometers & kilometers & 0.621 & miles \\
\hline Area & & & Area & & \\
\hline sq. inches & 6.452 & sq. centimeters & sq. centimeters & 0.155 & sq. inches \\
\hline sq. feet & 0.093 & sq. meters & sq. meters & 10.76 & sq. feet \\
\hline sq. yards & 0.0836 & sq. meters & sq. meters & 1.196 & sq. yards \\
\hline sq. miles & 2.6 & sq. kilometers & sq. kilometers & 0.4 & sq. miles \\
\hline Acres & 0.405 & hectares & hectares & 2.47 & acres \\
\hline Mass (weight) & & & Mass (weight) & & \\
\hline Ounces & 28.35 & grams & grams & 0.035 & ounces \\
\hline Pounds & 0.454 & kilograms & kilograms & 2.205 & pounds \\
\hline Ton & 0.907 & metric ton & metric ton & 1.102 & ton \\
\hline Volume & & & Volume & & \\
\hline Teaspoons & 5 & milliliters & milliliters & 0.033 & fluid ounces \\
\hline Tablespoons & 15 & milliliters & liters & 2.1 & pints \\
\hline fluid ounces & 30 & milliliters & liters & 1.057 & quarts \\
\hline Cups & 0.24 & liters & liters & 0.264 & gallons \\
\hline Pints & 0.47 & liters & cubic meters & 35.315 & cubic feet \\
\hline Quarts & 0.95 & liters & cubic meters & 1.308 & cubic yards \\
\hline Gallons & 3.8 & liters & & & \\
\hline cubic feet & 0.028 & cubic meters & & & \\
\hline cubic yards & 0.765 & cubic meters & & & \\
\hline Temperature & & & Temperature & & \\
\hline Fahrenheit & $\begin{array}{l}\text { subtract } 32 \text {, } \\
\text { then multiply } \\
\text { by } 5 / 9\end{array}$ & Celsius & Celsius & $\begin{array}{l}\text { multiply by } \\
9 / 5 \text {, then add } \\
32\end{array}$ & Fahrenheit \\
\hline Radioactivity & & & Radioactivity & & \\
\hline Picocuries & 37 & millibecquerel & millibecquerel & 0.027 & picocuries \\
\hline
\end{tabular}




\subsection{INTRODUCTION}

This document describes the fiscal year (FY) 2002 field activities associated with drilling three characterization boreholes (299-E17-22, 299-E17-23, and 299-E17-24) at the Immobilized LowActivity Waste (ILAW) disposal site in the 200 East Area of the Hanford Site. A fourth borehole was drilled (299-E17-25) after technical problems forced borehole 299-E17-24 to be decommissioned. The data obtained from these boreholes will support current and future ILAW disposal site performance assessments. Well locations are shown in Figure 1.

\subsection{PURPOSE AND SCOPE}

The three wells were drilled to support characterization of the physical properties of the soil at the ILAW disposal site and eventually the disposal of waste from the Hanford Site underground storage tanks. After waste is retrieved from the Hanford Site underground storage tanks, waste will be separated into two streams: (1) a low-volume, high-activity waste stream; and (2) a highvolume, low-activity waste stream. Both streams will be immobilized using the vitrification process. The immobilized high-level waste will be stored at the Hanford Site prior to shipment to a deep geological repository. The ILAW will be disposed at the Hanford Site, southwest of the Plutonium-Uranium Extraction Facility in the 200 East Area. The first ILAW disposal site characterization borehole (299-E17-21) was drilled in April 1998. The second borehole (299-E24-21) was drilled in March and April 2001.

The objective of the vadose and saturated zone characterization is to provide data to develop a geohydrologic conceptual model of the ILAW disposal site for use in the Hanford Site ILAW performance assessment (Reidel 2000). The conceptual model will be used in the performance assessment to model the movement of moisture and contaminants through the vadose zone. The characteristics of the saturated zones, as well as the results of in situ testing, will be used in groundwater modeling. After drilling, the boreholes were completed as a Resource Conservation and Recovery Act of 1976-compliant groundwater monitoring wells.

Descriptions of drilling, geologic conditions and materials, well construction, and well development for both wells are presented in Section 2.0. Section 3.0 provides a brief description of subsurface conditions based on geologic and hydrogeologic data collected during the installation of the wells. References are listed in Section 4.0. Well summary sheets and geologic borehole $\operatorname{logs}$ are included in Appendices A and B, respectively. Well development data are presented in Appendix C. Survey data report sheets are included in Appendix D.

All drilling activities were documented in accordance with BHI-EE-02, Environmental Requirements, Procedure 14.0, "Drilling, Maintaining, Remediating, and Decommissioning Resource Protection Wells, GeoProbe and Geotechnical Soil Borings." A geologic log was prepared for each well in accordance with BHI-EE-01, Environmental Investigations Procedures, Procedure 7.0, "Geologic Logging." The drilling data in this report are presented in the English units in which they were measured. 


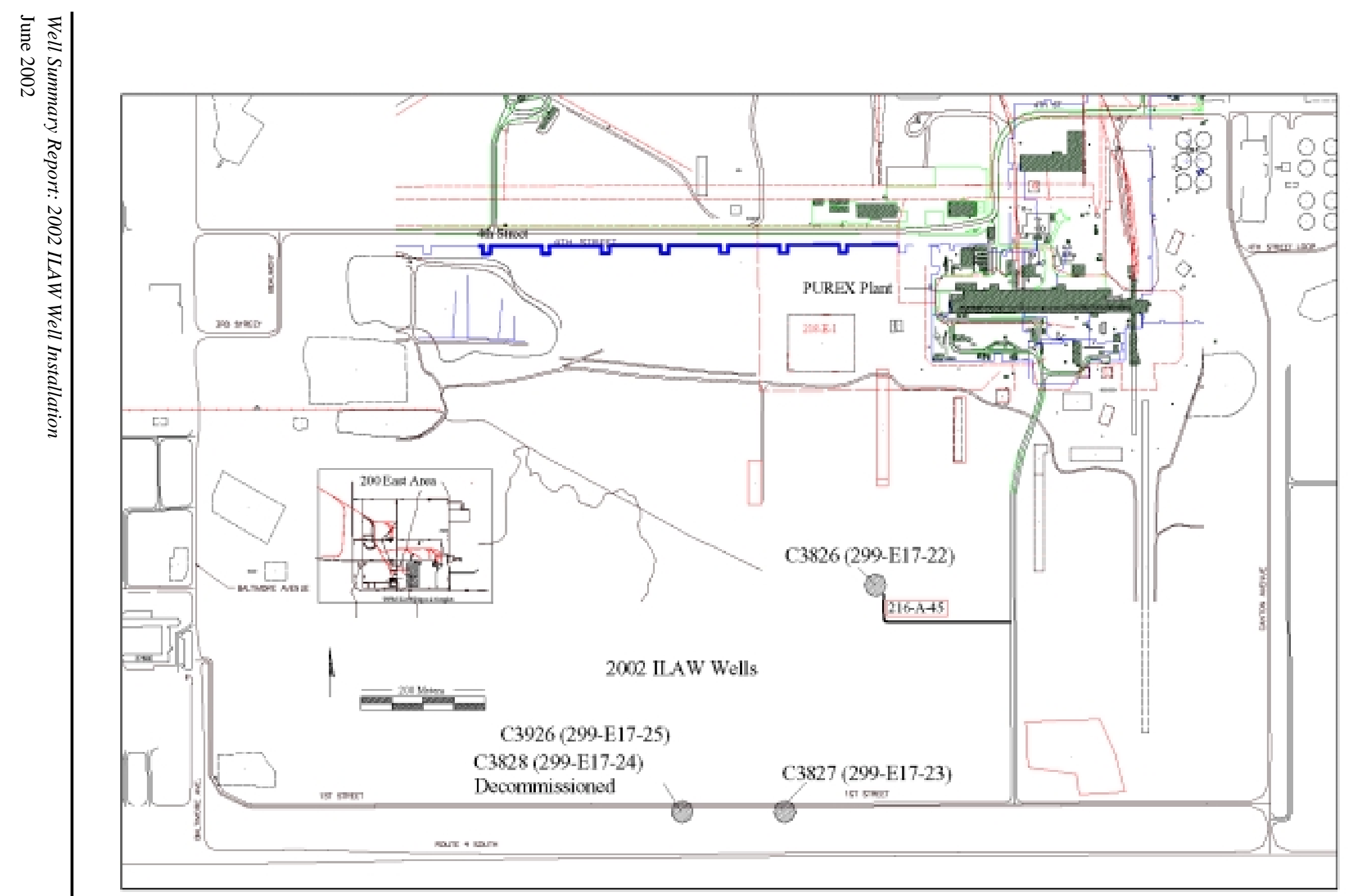

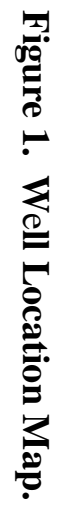




\subsection{TECHNICAL DATA}

\subsection{WELL C3826/299-E17-22}

This section contains a summary and description of drilling, well completion, and well development activities performed during the installation of well C3826/299-E17-22.

\subsubsection{Drilling Summary}

Drilling of well C3826/299-E17-22 was performed in accordance with the Characterization Plan for Fiscal Year 2002 Immobilized Low-Activity Waste Site Characterization Boreholes (Reidel 2002). Well summary information for this well is presented in Appendix A.

Drilling of well C3826/299-E17-22 using the dual-wall percussion method (Becker hammer drill $^{\circledR}$ ) began on March 29, 2002, advancing outer 9-in. outside diameter (OD) and inner 6-in. inside diameter (ID) temporary casing. Groundwater was encountered at approximately $322 \mathrm{ft}$ below ground surface (bgs) on April 9, 2002. Waste designation samples were collected at 70 and $170 \mathrm{ft}$ bgs, as described in Section 2.5. Archive samples (in volumes of 1 pint each) were collected at 5-ft intervals, and 23 split-spoon samples were collected from the intervals shown in Table 1. Split-spoon samplers consisted of two 2-ft (4 ft total) sample bodies coupled together in series with a 0.5 -ft drive shoe. The split spoons were $5 \mathrm{in}$. OD and contained four 1 - $\mathrm{ft}$ Lexan ${ }^{\circledR}$ liners (4 in. in diameter). Each sampler was driven on a 3.5-in.-diameter drill rod by the surface diesel hammer. The borehole was advanced to a total depth (TD) of $363 \mathrm{ft}$ bgs (temporary casing $362.5 \mathrm{ft}$ bgs) on April 11, 2002.

\subsubsection{Well Completion}

Well construction materials, filter-pack installation and initial well development, and the annular seal for well C3826 are discussed in the following subsections. A summary of well completion is provided in Table 2 and in the well summary sheets presented in Appendix A.

2.1.2.1 Screen, Riser Casing, and Filter Pack. A 35-ft-long 20-slot (0.020-in.) continuous v-wire wrap stainless-steel screen (with a 2-ft sump) and 10-20 mesh (0.0787- to 0.0331-in.) filter-pack sand were preselected for this well based on data from nearby wells and anticipated formation characteristics. The bottom of the sump was placed at $358.66 \mathrm{ft} \mathrm{bgs}$, and the bottom of the screen was placed at $356.66 \mathrm{ft}$ bgs. The top of the screen was located at $321.63 \mathrm{ft} \mathrm{bgs}$. The borehole was backfilled with 10-20 mesh filter-pack sand from TD to $15 \mathrm{ft}$ above the top of the screen (306.3 ft bgs).

\footnotetext{
${ }^{\circledR}$ Becker hammer is a registered trademark of Foremost Industries, Calgary, Canada.

${ }^{\circledR}$ Lexan is a registered trademark of General Electric Company, USA.
} 
Table 1. Split-Spoon Sample Intervals.

\begin{tabular}{|c|c|c|}
\hline Well C3826 & Well C3827 & Well C3828 \\
\hline $8-51$ (10 samples) & & \\
\hline & $53.5-57.5$ & $53.5-57.5$ \\
\hline $58-62$ & $58-62$ & $58-62$ \\
\hline $63.5-67.5$ & $62.5-66.5$ & $62.5-66.5$ \\
\hline $68-72$ & & \\
\hline $72.5-76$ & & \\
\hline $76.5-80.5$ & $76-80$ & \\
\hline $96-100$ & $98-102$ & \\
\hline $119-123$ & $119-123$ & $153.5-157.5$ \\
\hline $149-153$ & $149-153$ & $158-162$ \\
\hline & $153.5-157.5$ & $162.5-166.5$ \\
\hline & $158-162$ & \\
\hline $163.5-167.5$ & $162.5-166.5$ & \\
\hline $168-172$ & & \\
\hline $172.5-176.5$ & & \\
\hline $179-183$ & $179-183$ & \\
\hline $219-223$ & $219-223$ & \\
\hline
\end{tabular}

Note: Depths are in feet below ground surface.

2.1.2.2 Filter-Pack Installation and Initial Well Development. When installing the filterpack material the objectives are to introduce the silica sand into the annular space around the screen, settle the filter pack to eliminate void spaces, and begin removal of fines and recondition the borehole walls from the effects of drilling. A dual-flange surge block was used to develop and settle the filter-pack material opposite the screen. The surge block was typically operated for 20 minutes per 2- to 3-ft stroke interval. Care was taken to maintain overlap between the filter sand and temporary casing so that formation material would not cave in against the well screen. The level of the filter pack was measured periodically with a weighted steel tape to monitor progress and ensure the integrity of the completion. The bottom of the well was also checked for fill material to determine if any fine material was accumulating in the screen during surging. This material was removed, as needed.

2.1.2.3 Annular Seal. Approximately $9 \mathrm{ft}$ (297.0 to $306.3 \mathrm{ft}$ bgs) of annular seal was constructed above the filter pack using 0.25 -in. bentonite pellets, and a granular bentonite seal placed to $9.4 \mathrm{ft}$ bgs. A grout seal was placed from the bentonite seal to ground surface. The grout seal consisted of Portland cement mixed with no more than 5\% bentonite by weight, in accordance with Washington Administrative Code (WAC) 173-160. 


\subsubsection{Final Well Development and Pumping Test}

Final well development was performed on May 21, 2002, after the surface cement pad and protective casing were installed. A 3-HP electric submersible pump (Grundfos ${ }^{\circledR}$ type 16S30-24) was used to pump at two depth intervals until the turbidity was less than 5 nephelometric turbidity units (NTU) and other water parameters had stabilized (i.e., temperature, conductivity, $\mathrm{pH}$ ). First, the pump was operated with the intake $5 \mathrm{ft}$ above the bottom of the well screen. At this depth the pump could only produce $11 \mathrm{gal} / \mathrm{min}$. Drawdown of the water level during pumping was monitored by a pressure transducer and recorded in a datalogger. Water samples (C3828_1, C3828_2, and C3828_3) were collected at this depth for analyses by Pacific Northwest National Laboratory (PNNL). The pump intake was then raised to $22 \mathrm{ft}$ above the bottom of the screen, and pumping resumed until the turbidity was again below 5 NTU. Final groundwater parameters are presented in Table 3.

\subsection{WELL C3827/299-E17-23}

This section contains a summary and description of drilling, well completion, and well development activities performed during the installation of well C3927/199-E17-23.

\subsubsection{Drilling Summary}

Drilling of well C3827/299-E17-23 was performed in accordance with the characterization plan for FY 2002 (Reidel 2002). Well summary information for this well is presented in Appendix A.

Drilling of well C3827/299-E17-23, using the dual-wall percussion method (Becker hammer drill) began on April 17, 2002, advancing outer 9-in. OD and inner 6-in. ID temporary casing. Groundwater was encountered at approximately $332.5 \mathrm{ft}$ bgs on April 25, 2002. Archive samples were collected at 5-ft intervals, and 12 split-spoon samples were collected from the intervals shown in Table 1. The split-spoon samplers for this borehole retrieved $4 \mathrm{ft}$ of sediment in four 1-ft-length Lexan liners. The borehole was advanced to a TD of $372 \mathrm{ft}$ bgs (temporary casing $372 \mathrm{ft}$ bgs) on April 25, 2002.

\subsubsection{Well Completion}

Well construction materials, filter-pack installation and initial well development, and the annular seal for well C3827 are discussed in the following subsections. A summary of well completion is provided in Table 2 and in the well summary sheets presented in Appendix A.

\footnotetext{
${ }^{\circledR}$ Grundfos is a registered trademark of Grundfos Pumps Corporation, Clovis, California.
} 
Table 2. Well Completion Summary.

\begin{tabular}{|c|c|c|c|c|c|c|c|c|c|c|c|}
\hline \multirow[b]{2}{*}{ Well Name } & \multirow[b]{2}{*}{ Well ID } & \multirow{2}{*}{$\begin{array}{c}\text { Water } \\
\text { Level } \\
\text { (ft bgs) }\end{array}$} & \multicolumn{5}{|c|}{ Screen } & \multirow{2}{*}{$\begin{array}{c}\text { Sandpack } \\
\begin{array}{c}\text { Interval } \\
\text { (ft bgs) }\end{array}\end{array}$} & \multirow{2}{*}{$\begin{array}{c}\begin{array}{c}\text { Bentonite } \\
\text { Pellets }\end{array} \\
\begin{array}{c}\text { Interval } \\
\text { (ft bgs) }\end{array}\end{array}$} & \multirow{2}{*}{$\begin{array}{c}\begin{array}{c}\text { Granular } \\
\text { Bentonite Seal }\end{array} \\
\begin{array}{c}\text { Interval } \\
\text { (ft bgs) }\end{array}\end{array}$} & \multirow{2}{*}{$\begin{array}{c}\text { Grout } \\
\begin{array}{c}\text { Interval } \\
\text { (ft bgs) }\end{array}\end{array}$} \\
\hline & & & $\begin{array}{c}\text { Screen } \\
\text { Top } \\
\text { (ft bgs) }\end{array}$ & $\begin{array}{l}\text { Screen } \\
\text { Bottom } \\
\text { (ft bgs) }\end{array}$ & $\begin{array}{c}\text { Screen } \\
\text { Length (ft) }\end{array}$ & $\underset{(\mathbf{f t})}{\operatorname{Sump}}$ & $\begin{array}{c}\text { Screen } \\
\text { Material }\end{array}$ & & & & \\
\hline 299-E17-22 & C3826 & 321.82 & 321.63 & 356.66 & 35 & 2 & 304L SS & $306.3-362.7$ & $297.0-306.3$ & $9.4-297.0$ & $0-9.4$ \\
\hline 299-E17-23 & C 3827 & 332.5 & 332.98 & 368.10 & 35 & 2 & 304L SS & $323.0-370.5$ & $316.1-323.0$ & $316.1-9.9$ & $0-9.9$ \\
\hline 299-E17-24 & C3828 & 341.3 & NA & NA & NA & NA & NA & $330-383$ & NA & $330-9.5$ & $0-9.5$ \\
\hline 299-E17-25 & C3926 & 337.67 & 336.56 & 371.57 & 35 & 2 & 304L SS & $326.8-382.5$ & $316-326.8$ & $316-10.8$ & $0-10.8$ \\
\hline
\end{tabular}

$\mathrm{NA}=$ not applicable

$\mathrm{SS}=$ stainless steel

Table 3. Well Development Data.

\begin{tabular}{|c|c|c|c|c|c|c|c|c|c|c|c|}
\hline Well Name & Well ID & $\begin{array}{c}\text { Static } \\
\text { Water } \\
\text { Level } \\
\text { (ft bgs) }\end{array}$ & $\begin{array}{c}\text { Development } \\
\text { Date }\end{array}$ & $\begin{array}{r}\text { Duration } \\
\text { (minutes) }\end{array}$ & $\begin{array}{c}\text { Final } \\
\text { Turbidity } \\
\text { (NTU) }\end{array}$ & $\begin{array}{c}\text { Final } \\
\text { Conductivity } \\
(\mu \mathrm{S} / \mathrm{cm})\end{array}$ & $\begin{array}{c}\text { Final pH } \\
\text { (standard } \\
\text { units) }\end{array}$ & $\begin{array}{l}\text { Final } \\
\text { Temp. } \\
\left({ }^{\circ} \mathrm{C}\right)\end{array}$ & $\begin{array}{c}\text { Final Flow } \\
\text { Rate } \\
\text { (gal/min) }\end{array}$ & $\begin{array}{l}\text { Final } \\
\text { Drawdown } \\
\quad(\mathbf{f t})\end{array}$ & $\begin{array}{l}\text { Total } \\
\text { Gallons } \\
\text { Pumped }\end{array}$ \\
\hline 299-E17-22 & C3826 & 321.82 & $5 / 21 / 02$ & 99 & 2.66 & 454 & 7.96 & 19.6 & 13 & 0 & 1,150 \\
\hline 299-E17-23 & C3827 & 332.51 & $5 / 20 / 02$ & 75 & 4.34 & 513 & 7.79 & 21.4 & 11 & 0 & 870 \\
\hline 299-E17-24 & C3828 & 341.3 & NA & NA & NA & NA & NA & NA & NA & NA & NA \\
\hline 299-E17-25 & C3926 & 337.62 & $5 / 20 / 02$ & 88 & 4.32 & 428 & 7.77 & 20.1 & 12 & 0 & 1,020 \\
\hline
\end{tabular}

$\mathrm{NA}=$ not applicable 
2.2.2.1 Screen, Riser Casing, and Filter Pack. A 35-ft-long 20-slot (0.020-in.) continuous v-wire wrap stainless-steel screen (with a 2-ft sump) and 10-20 mesh (0.0787- to 0.0331-in.) filter-pack sand were preselected for this well based on data from nearby wells and anticipated formation characteristics. The bottom of the sump was placed at $370.11 \mathrm{ft} \mathrm{bgs}$, and the bottom of the screen placed at $368.10 \mathrm{ft}$ bgs. The top of the screen was located at $332.98 \mathrm{bgs}$. The borehole was backfilled with 10-20 mesh filter-pack sand from TD to $10 \mathrm{ft}$ above the top of the screen (323 ft bgs). Filter-pack installation at injection well C3827 followed the same procedure as previously described for extraction well C3826 (see Section 2.1.2.2).

2.2.2.2 Annular Seal. Approximately $7 \mathrm{ft}$ (316.1 to $323.0 \mathrm{ft} \mathrm{bgs}$ ) of annular seal was constructed above the filter pack using 0.25-in. bentonite pellets and a granular bentonite seal placed to $9.9 \mathrm{ft}$ bgs. A grout seal was placed from the bentonite seal to ground surface. The grout seal consisted of Portland cement mixed with no more than $5 \%$ bentonite by weight, in accordance with WAC 173-160.

\subsubsection{Final Well Development and Pumping Test}

Final well development was performed on May 20, 2002, after the surface cement pad and protective casing had been installed. A 3-HP electric submersible pump was used at two depths to develop the well. First, the pump intake was set $2 \mathrm{ft}$ above the bottom of the screen, and pumping continued until the turbidity was less than 5 NTU. A pressure transducer was used to monitor water-level drawdown during pumping, and information was recorded in a datalogger. Other parameters monitored during pumping were temperature, conductivity, and $\mathrm{pH}$. At this depth, water samples (C3827_1, C3827_2, and C3827_3) were collected for PNNL analyses. The pump intake was raised to $16 \mathrm{ft}$ above the bottom of the screen, and pumping resumed until the turbidity was less than 5 NTU. The pumping rate was $12 \mathrm{gal} / \mathrm{min}$. Final groundwater parameters are presented in Table 3. No significant water-level drawdown was noted at either depth.

\subsection{WELL C3828/299-E17-24}

This section contains a summary and description of drilling and well decommissioning activities performed during the attempted installation of well C3828/299-E17-24.

\subsubsection{Drilling Summary}

Drilling of well C3828/299-E17-24 was performed in accordance with the characterization plan for FY 2002 (Reidel 2002). Well summary information for this well is presented in Appendix A.

Drilling of well C3828/299-E17-24 using the dual-wall percussion method (Becker hammer drill) began on May 2, 2002, advancing outer 9-in. OD and inner 6-in. ID in temporary casing. Groundwater was encountered at approximately $340 \mathrm{ft}$ bgs on April 9, 2002. Six split-spoon samples were collected from the intervals shown in Table 1. The split-spoon samplers for this borehole retrieved $4 \mathrm{ft}$ of sediment in two 2-ft-length Lexan liners. The borehole was advanced to a TD of $383 \mathrm{ft} \mathrm{bgs} \mathrm{(temporary} \mathrm{casing} 383 \mathrm{ft}$ bgs) on May 6, 2002. 


\subsubsection{Well Completion}

Borehole C3828 was drilled to $383 \mathrm{ft}$ bgs and passed the straightness test prior to installation of the well screen. When the well construction was started, the drilling subcontractor was unable to get a measuring tape to the bottom of the well in the annular space between the 4-in. stainlesssteel permanent casing and the inner 6-in. temporary casing. This measurement is critical to ensure the proper placement of the silica sand pack around the well screen. The well was observed to veer to the east at approximately $85 \mathrm{ft}$ bgs. During drilling a rock was hit at $280 \mathrm{ft}$, which may also have deflected the drill bit. After a discussion with $\mathrm{CH} 2 \mathrm{M}$ Hill Hanford Group, Inc. and project management, it was agreed to decommission well C3828, move the drilling rig, and drill a new borehole.

A summary of well decommissioning is provided in Table 2 and in the well summary sheets presented in Appendix A. A well decommissioning profile for well C3828 (299-E17-24) was generated by the Groundwater/Vadose Zone Integration Project single point of contact prior to the actual well decommissioning.

2.3.2.1 Well Decommissioning. During backpulling of the temporary casing from well C 3828 (299-E17-24), silica sand was emplaced from $383 \mathrm{ft}$ bgs to approximately $330 \mathrm{ft}$ bgs, granular bentonite (crumbles) placed from $330 \mathrm{ft}$ bgs to $9.5 \mathrm{ft} \mathrm{bgs}$, and a concrete seal was placed from the bentonite seal to ground surface. A brass marker was placed in the surface of the concrete seal. Decommissioning was completed on May 10, 2002.

\subsection{WELL C3926/299-E17-25}

This section contains a summary and description of drilling, well completion, and well development activities performed during the installation of well C3926/299-E17-25.

\subsubsection{Drilling Summary}

Drilling of extraction well C3926/299-E17-25 was performed as a redrill of well C3828. The borehole location was set approximately $10 \mathrm{ft}$ due west of the $\mathrm{C} 3828$ site. The well was drilled in accordance with the characterization plan for FY 2002 (Reidel 2002). Well summary information for this well is presented in Appendix A.

Drilling of well C3926/299-E17-25 using the dual-wall percussion method (Becker hammer drill) began on May 10, 2002, advancing outer 9-in. OD and inner 6-in. ID in temporary casing. Groundwater was encountered at approximately $338 \mathrm{ft}$ bgs on May 13, 2002. Archive grab samples were collected at 10-ft intervals. No split-spoon samples were collected. The borehole was advanced to a TD of $382.5 \mathrm{ft}$ bgs on May 13, 2002. 


\subsubsection{Well Completion}

Well construction materials, filter-pack installation and initial well development, and annular seal for well C3826 are discussed in the following subsections. A summary of well completion is provided in Table 2 and in the well summary sheets presented in Appendix A.

2.4.2.1 Screen, Riser Casing, and Filter Pack. A 35-ft 20-slot (0.020-in.) continuous v-wire wrap stainless-steel screen (with a 2-ft sump) and 10-20 mesh (0.0787- to 0.0331-in.) filter-pack sand were preselected for this well based on data from nearby wells and anticipated formation characteristics. The bottom of the sump was placed at $373.58 \mathrm{ft}$ bgs and the bottom of the screen placed at $371.57 \mathrm{ft}$ bgs. The top of the screen was located at $336.56 \mathrm{ft}$ bgs. The borehole was backfilled with 10-20 mesh filter-pack sand from TD to $10 \mathrm{ft}$ above the top of the screen (326.8 ft bgs). Filter-pack installation at well C3827 followed the same procedure as previously described for well C3826 (see Section 2.1.2.2).

2.4.2.2 Annular Seal. Approximately $10 \mathrm{ft}$ ( 326.8 to $316 \mathrm{ft}$ bgs) of annular seal was constructed above the filter pack using 0.38 -in. bentonite pellets and a granular bentonite seal placed to $9.4 \mathrm{ft}$ bgs. A grout seal was placed from the bentonite seal to ground surface. The grout seal consisted of Portland cement mixed with no more than 5\% bentonite by weight, in accordance with WAC 173-160.

2.4.2.3 Final Well Development and Pumping Test. Final well development was performed on May 20, 2002, after the surface pad and protective casing had been set. A 3-HP electric submersible pump was first set near the bottom of the screen interval, with the pump intake at $6 \mathrm{ft}$ above the bottom of the screen. From that depth, the pump could only produce $11 \mathrm{gal} / \mathrm{min}$. A pressure transducer was used to monitor water-level drawdown during pumping, and information was stored in a Hermit ${ }^{\mathrm{TM}} 3000$ datalogger. Pumping continued until the turbidity was measured to be less than $5 \mathrm{NTU}$. Other water quality parameters measured during pumping were temperature, conductivity, and pH. Water samples (C3826_1, C3826_2 and C3826_3) were collected for PNNL analyses. The pump intake was then raised to $20 \mathrm{ft}$ above the bottom of the screen, and pumping resumed until the turbidity was less than 5 NTU. The pumping rate was about $12 \mathrm{gal} / \mathrm{min}$. Final groundwater-quality parameters are presented in Table 3 . No significant drawdown of the water table was noted at either pumping depth.

\subsection{WASTE MANAGEMENT}

Waste for all boreholes was managed in accordance with the Data Quality Objective Summary Report for ILAW Well Installation - Waste Disposition (BHI 2002) and the Site Specific Waste Management Instruction Well Decommissioning, Maintenance and Sampling (Stocker 2000).

\footnotetext{
${ }^{\mathrm{TM}}$ Hermit is a trademark of In-Situ Inc., Laramie, Wyoming.
} 


\subsubsection{Vadose Zone Cuttings}

As discussed in the data quality objective (DQO) summary report (BHI 2002), waste designation samples were collected from ILAW borehole C3826 (299-E17-22) at two locations (70 and $170 \mathrm{ft}$ bgs). Soil samples B149P3 (70 ft) and B149P5 (170 ft) were analyzed for selected radionuclides and nitrate per the DQO summary report (BHI 2002).

Initial radiological screening (for sample shipping purposes) showed nondetects for gamma emitters and $18 \mathrm{pCi} / \mathrm{g}$ for gross beta. While gross beta was not discussed as a contaminant of concern in the DQO summary report (BHI 2002), after a discussion with the Bechtel Hanford, Inc. waste management task lead, it was determined that it was appropriate to compare the screening data with the $90 \%$ upper confidence limit (UCL) background value for gross beta. The published background value is $22.96 \mathrm{pCi} / \mathrm{g}$ (DOE-RL 1996). As shown in Table 4, laboratory sample values were compared to the $90 \%$ UCL as requested by the DQO, for site background data. All reported values are less than background.

Table 4. Waste Designation Sample Results, Well C3826 (299-E17-22).

\begin{tabular}{|l|c|c|c|}
\hline \multicolumn{1}{|c|}{ Constituent } & $\begin{array}{c}\mathbf{9 0 \%} \text { UCL } \\
\text { Background }\end{array}$ & $\begin{array}{c}\text { Sample B149P3 } \\
(\mathbf{7 0 ~ f t})\end{array}$ & $\begin{array}{c}\text { Sample B149P5 } \\
(\mathbf{1 7 0} \mathrm{ft})\end{array}$ \\
\hline Cesium-137 & $0.0919 \mathrm{pCi} / \mathrm{g}$ & Nondetect & Nondetect \\
\hline Strontium-90 & $0.167 \mathrm{pCi} / \mathrm{g}$ & $-0.014 \mathrm{pCi} / \mathrm{g}$ & $-0.149 \mathrm{pCi} / \mathrm{g}$ \\
\hline Uranium-234 & $1.1 \mathrm{pCi} / \mathrm{g}$ & $0.336 \mathrm{pCi} / \mathrm{g}$ & $0.611 \mathrm{pCi} / \mathrm{g}$ \\
\hline Uranium-235 & $0.109 \mathrm{pCi} / \mathrm{g}$ & $0.057 \mathrm{pCi} / \mathrm{g}$ & $0.085 \mathrm{pCi} / \mathrm{g}$ \\
\hline Uranium-238 & $1.06 \mathrm{pCi} / \mathrm{g}$ & $0.46 \mathrm{pCi} / \mathrm{g}$ & $0.423 \mathrm{pCi} / \mathrm{g}$ \\
\hline Plutonium-238 & $0.0047 \mathrm{pCi} / \mathrm{g}$ & $0.003 \mathrm{pCi} / \mathrm{g}$ & $-0.008 \mathrm{pCi} / \mathrm{g}$ \\
\hline Plutonium-239/240 & $0.0192 \mathrm{pCi} / \mathrm{g}$ & $-0.003 \mathrm{pCi} / \mathrm{g}$ & $0.008 \mathrm{pCi} / \mathrm{g}$ \\
\hline Nitrate & $99.38 \mathrm{mg} / \mathrm{kg}$ & $2.79 \mathrm{mg} / \mathrm{kg}$ & $2.29 \mathrm{mg} / \mathrm{kg}$ \\
\hline
\end{tabular}

Waste from boreholes C3827 (299-E17-23), C3828 (299-E17-24), and C3926 (299-E27-25) did not require waste designation sampling. The drilling area and drill cuttings were monitored regularly for radioactive contaminants; no contaminants were detected above background levels. Drilling spoils from above the water table were accumulated in piles near the point of generation until surveyed by a radiological control technician. Spoils piles were approved for return to ground following clearance from the radiological control technician, the project task lead, and the waste management task lead.

\subsubsection{Saturated Zone Cuttings}

Drill cuttings removed below the water table in all four boreholes were contained in waste storage drums for final disposition. 


\subsubsection{Purgewater}

All groundwater pumped from these wells during development activities was contained and transferred to purgewater trucks for final disposal at the Purgewater Storage and Treatment Facility and/or ModuTanks, ${ }^{\mathrm{TM}}$ in accordance with the DQO summary report (BHI 2002).

\subsection{WELL ACCEPTANCE}

A well acceptance walkdown for the three completed wells was performed on May 21, 2002 (see Table 5 for a summary).

Table 5. Summary of Well Drilling and Survey Data.

\begin{tabular}{|l|c|c|c|c|c|c|c|}
\hline Well Name & Well ID & $\begin{array}{c}\text { Drilling } \\
\text { Start } \\
\text { Date }\end{array}$ & $\begin{array}{c}\text { Drilling } \\
\text { Finish Date }\end{array}$ & $\begin{array}{c}\text { Northing } \\
\text { (Brass Cap) } \\
(\mathbf{m})\end{array}$ & $\begin{array}{c}\text { Easting }_{\text {(Brass Cap) }} \\
(\mathbf{m})\end{array}$ & $\begin{array}{c}\text { Ground-Surface } \\
\text { Elevation }^{\mathbf{b}} \\
\text { (Brass Cap) } \\
(\mathbf{m})\end{array}$ & $\begin{array}{c}\text { Total Depth } \\
\text { (ft bgs) }\end{array}$ \\
\hline 299-E17-22 & C3826 & $3 / 27 / 02$ & $4 / 11 / 02$ & 135195.921 & 574841.067 & 220.589 & 363 \\
\hline 299-E17-23 & C3827 & $4 / 16 / 02$ & $4 / 26 / 02$ & 134842.766 & 574694.485 & 223.843 & 372 \\
\hline 299-E17-24 & C3828 & $5 / 1 / 02$ & $5 / 06 / 02$ & 134845.545 & 574518.125 & 224.801 & 383 \\
\hline 299-E17-25 & C3926 & $5 / 10 / 02$ & $5 / 13 / 02$ & 134845.913 & 574515.171 & 225.028 & 382.5 \\
\hline
\end{tabular}

NOTE: Feet are used because field measurements were reported and recorded in English units.

${ }^{a}$ Northing and easting coordinates are based on Washington State Plane Coordinates (North American Datum of 1983[91]).

${ }^{\mathrm{b}}$ North American Vertical Datum of 1988 values rounded to $0.001 \mathrm{~m}$.

\subsection{CIVIL SURVEY}

Well location and elevation surveys were performed on the wells in May 2002 by Rogers Surveying, Inc. The coordinates for the wells were determined using Trimble 4000ssi ${ }^{\text {TM }}$ dualfrequency global positioning system receivers, operating in real-time kinematic mode. The horizontal control for this survey is based on a global positioning system control network designed and surveyed by Rogers Surveying, Inc., in support of the Hanford Site Mapping Project.

Elevations were determined using a Leica Geosystems N3003 electronic bar code reading level and bar code rod. The vertical control for these wells perpetuated from horizontal control monument HSWB044. All coordinates are referenced to the Washington Coordinate System, North American Datum of 1983/1991. Elevations are referenced to the North American Vertical Datum of 1988. All results are reported in metric units with a vertical accuracy of $+/-0.001 \mathrm{~m}$

\footnotetext{
${ }^{\mathrm{TM}}$ ModuTank is a trademark of ModuTank Inc., Long Island City, New York.

${ }^{\mathrm{TM}}$ Trimble 4000ssi is a trademark of Trimble Navigation Limited
} 
and horizontal accuracy of $+/-0.001 \mathrm{~m}$. Surveying was performed in accordance with the requirements of BHI-EE-01, Procedure 1.6, "Survey Requirements and Techniques."

\subsection{SUBSURFACE DESCRIPTION}

\subsection{EAST AREA GEOLOGY}

The stratigraphy of the ILAW disposal site consists of the Hanford formation and the Ringold Formation overlying the Columbia River Basalt Group (Reidel 2000). Surficial sediments are mainly eolian deposits consisting of reworked Hanford Site sands and silts.

\subsubsection{Well C3826/299-E17-22 Borehole Geology}

The first $6 \mathrm{ft}$ consisted of fine sand and silt, and the sand-dominated sequence of the Hanford formation continued until $216 \mathrm{ft}$ bgs. The sand was moist to about $6 \mathrm{ft}$, and then dry below that depth until near the top of groundwater. Trace amounts of caliche fragments were noted on the borehole log. The sediment was predominantly gravelly sand from 216 to $238 \mathrm{ft}$, sand from 238 to $274 \mathrm{ft}$, gravelly sand from 274 to $293 \mathrm{ft}$, basal-gravel (Hanford formation) from 293 to $352 \mathrm{ft}$, and sandy gravel (Ringold Formation) from 352 to $363 \mathrm{ft}$ (TD).

Geologic borehole logs are included in Appendix B and stratigraphic information summarized in Table 6.

Table 6. Drilling Information.

\begin{tabular}{|c|c|c|c|c|c|c|}
\hline Well Name & Well ID & $\begin{array}{c}\text { Ground Surface } \\
\text { Elevation }^{\mathrm{a}} \\
\text { (Estimated) } \\
(\mathrm{m})\end{array}$ & $\begin{array}{c}\text { Top of Hanford } \\
\text { Gravel Sequence } \\
\text { (ft bgs) }\end{array}$ & $\begin{array}{l}\text { Hanford/Ringold } \\
\text { Contact (ft bgs) }\end{array}$ & $\begin{array}{l}\text { Groundwater } \\
\text { Depth } \\
\text { (ft bgs) }\end{array}$ & $\begin{array}{l}\text { Total Depth } \\
\text { (ft bgs) }\end{array}$ \\
\hline 299-E17-22 & C3826 & 220.494 & 293 & 352 & 321.8 & 363 \\
\hline 299-E17-23 & C3827 & 223.370 & 272 & Indistinct & 332.5 & 372 \\
\hline 299-E17-24 & C3828 & 224.625 & 277 & Indistinct & $341.3^{b}$ & 383 \\
\hline 299-E17-25 & C3926 & 224.625 & 275 & Indistinct & 337.6 & 382.5 \\
\hline
\end{tabular}

${ }^{\text {a }}$ North American Vertical Datum of 1988.

${ }^{\mathrm{b}}$ Water level could be inaccurate due to off-vertical drill casing.

\subsubsection{Well C3827/299-E17-23 Borehole Geology}

At this location the surface deposit of silty sand extended to about $8 \mathrm{ft}$ bgs, followed by basaltrich sand from 8 to $23 \mathrm{ft}$. Gravelly sand with fine pebbles continued from 23 to $29 \mathrm{ft}$, and then Hanford sand from 29 to $233 \mathrm{ft}$. This sand was slightly moist until about $130 \mathrm{ft}$ and then dry 
below that depth. A gradational change to sandy gravel occurred from 233 to $236 \mathrm{ft}$, and then sand again to $254 \mathrm{ft}$. From 254 to $272 \mathrm{ft}$, the sediment alternated from gravelly sand to sandy gravel with fine- to medium-sized gravel pebbles. At $272 \mathrm{ft}$, the basal-gravel-dominated Hanford formation was encountered. There was not a clear contact noted between Hanford and Ringold gravel formations, but there was a possible contact at about $358 \mathrm{ft}$ as sandy gravel continued until the total drill depth of $372 \mathrm{ft}$ bgs.

Geologic borehole logs are included in Appendix B, and stratigraphic information is summarized in Table 6.

\subsubsection{Well C3828/299-E17-24 Borehole Geology}

Sediment from the surface to $33 \mathrm{ft}$ bgs consisted of sand, with trace amounts of silt and fine gravel. Sand continued from 33 to $234 \mathrm{ft}$. The sand contained occasional fragments of silt and clay, which were moist and reacted strongly with $10 \%$ hydrochloric acid. A possible paleosol was noted in a split-spoon sample at $157 \mathrm{ft}$. The sand was slightly moist until about $220 \mathrm{ft}$, and dry below that depth. Gravelly sand with fine pebbles was encountered from 234 to $237 \mathrm{ft}$, and then sand to $244 \mathrm{ft}$. Sandy gravel, again mostly fine to very fine pebbles, extended from 244 to $262 \mathrm{ft}$, then sand to $277 \mathrm{ft}$. An abrupt contact with sandy gravel at $277 \mathrm{ft}$ was the basal Hanford gravel sequence. The gravel was occasionally cobble to boulder in size, with several intervals with silt coatings on gravel. There was no clear contact between Hanford and Ringold Formations; no open-framework gravel was encountered at this borehole. A large basalt boulder was drilled through at 367 to $369 \mathrm{ft}$, and basalt-rich gravel extended to the total depth of $383 \mathrm{ft}$.

Geologic borehole logs are included in Appendix B, and stratigraphic information is summarized in Table 6.

\subsubsection{Well C3926/299-E17-25 Borehole Geology}

From the surface to $36 \mathrm{ft}$ bgs, the sediment graded from slightly silty sand to gravelly sand and sand from 36 to $230 \mathrm{ft}$. This borehole also showed traces of silt, clay, and caliche fragments, but not to the extent seen in well C3828. The sand was slightly moist until about $220 \mathrm{ft}$ and dry below that depth. Gravelly sand was seen from 230 to $235 \mathrm{ft}$, and then sand to $240 \mathrm{ft}$. Gravelly sand to sandy gravel was encountered from 240 to $259 \mathrm{ft}$, and then sand to $275 \mathrm{ft}$. The basal Hanford gravel sequence started at $275 \mathrm{ft}$, with gravel up to cobble and boulder size. There was no clear contact between Hanford and Ringold gravel, as sandy gravel continued to the total drill depth of $382.5 \mathrm{ft}$. At a depth interval of approximately 368 to $378 \mathrm{ft}$, the silt fraction in the gravel was a very dark brown (almost black) then back to a light brown, as seen earlier in this borehole and in other boreholes below the water table.

Geologic borehole logs are included in Appendix B, and stratigraphic information is summarized in Table 6. 


\subsection{HYDROGEOLOGY}

The uppermost aquifer in the vicinity of the ILAW disposal site is within the fluvial gravels of the Ringold Formation and flood deposits of the Hanford formation. The Elephant Mountain Member of the Columbia River Basalt Group forms the base of the unconfined aquifer. Drawdown information from well development pumping is shown in Table 7 . No other aquifer testing was performed.

Table 7. Pumping Information.

\begin{tabular}{|c|c|c|c|c|c|c|}
\hline $\begin{array}{c}\text { Well } \\
\text { Name }\end{array}$ & $\begin{array}{c}\text { Well } \\
\text { ID }\end{array}$ & $\begin{array}{c}\text { Groundwater } \\
\text { Level } \\
\text { (ft bgs) }\end{array}$ & $\begin{array}{c}\text { Final Flow } \\
\text { Rate } \\
\text { (gal/min) }\end{array}$ & $\begin{array}{c}\text { Drawdown } \\
(\mathbf{f t})\end{array}$ & $\begin{array}{c}\text { Pumping } \\
\text { Duration } \\
\text { (minutes) }\end{array}$ & $\begin{array}{c}\text { Recovery } \\
\text { (minutes) }\end{array}$ \\
\hline $299-\mathrm{E} 27-22$ & $\mathrm{C} 3826$ & 321.8 & 13 & 0 & 99 & 0 \\
\hline $299-\mathrm{E} 17-23$ & $\mathrm{C} 3827$ & 332.5 & 11 & 0 & 75 & 0 \\
\hline $299-\mathrm{E} 17-24$ & $\mathrm{C} 3828$ & $341.3^{\mathrm{a}}$ & $\mathrm{NA}$ & $\mathrm{NA}$ & NA & NA \\
\hline $299-\mathrm{E} 17-25$ & $\mathrm{C} 3926$ & 337.6 & 12 & 0 & 88 & 0 \\
\hline
\end{tabular}

${ }^{a}$ Water level could be inaccurate due to off-vertical drill casing.

${ }^{\mathrm{b}}$ Pump was of insufficient size to generate a drawdown at these depths.

$\mathrm{NA}=$ not applicable

\subsection{REFERENCES}

BHI-EE-01, Environmental Investigations Procedures, Bechtel Hanford, Inc., Richland, Washington.

BHI-EE-02, Environmental Requirements, Bechtel Hanford, Inc., Richland, Washington.

BHI, 2002, Data Quality Objective Summary Report for ILAW Well Installation - Waste Disposition, BHI-01603, Rev. 0, Bechtel Hanford, Inc., Richland, Washington.

DOE-RL, 1996, Hanford Site Background: Part 2, Soil Background for Radionuclides, DOE/RL-96-12, U.S. Department of Energy, Richland Operations Office, Richland, Washington.

Reidel, S. P., 2000, Second ILAW Site Borehole Characterization Plan, PNNL-13283, Pacific Northwest National Laboratory, Richland, Washington.

Reidel, S. P., 2002, Characterization Plan for Fiscal Year 2002 Immobilized Low-Activity Waste Site Characterization Boreholes, PNNL-13283-1, Pacific Northwest National Laboratory, Richland, Washington. 
Resource Conservation and Recovery Act of 1976, 42 U.S.C. 6901, et seq.

Stocker, D. E., 2000, Site Specific Waste Management Instruction Well Decommissioning, Maintenance and Sampling, WMI-WELL001, Rev. 5, Bechtel Hanford, Inc., Richland, Washington.

WAC 173-160, "Minimum Standards for Construction and Maintenance of Wells," Washington Administrative Code, as amended. 
BHI-01647

Rev. 0

Well Summary Report: 2002 ILAW Well Installation

June 2002 
APPENDIX A

\section{WELL SUMMARY SHEETS}


BHI-01647

Rev. 0

Well Summary Report: 2002 ILAW Well Installation

June 2002

A-ii 


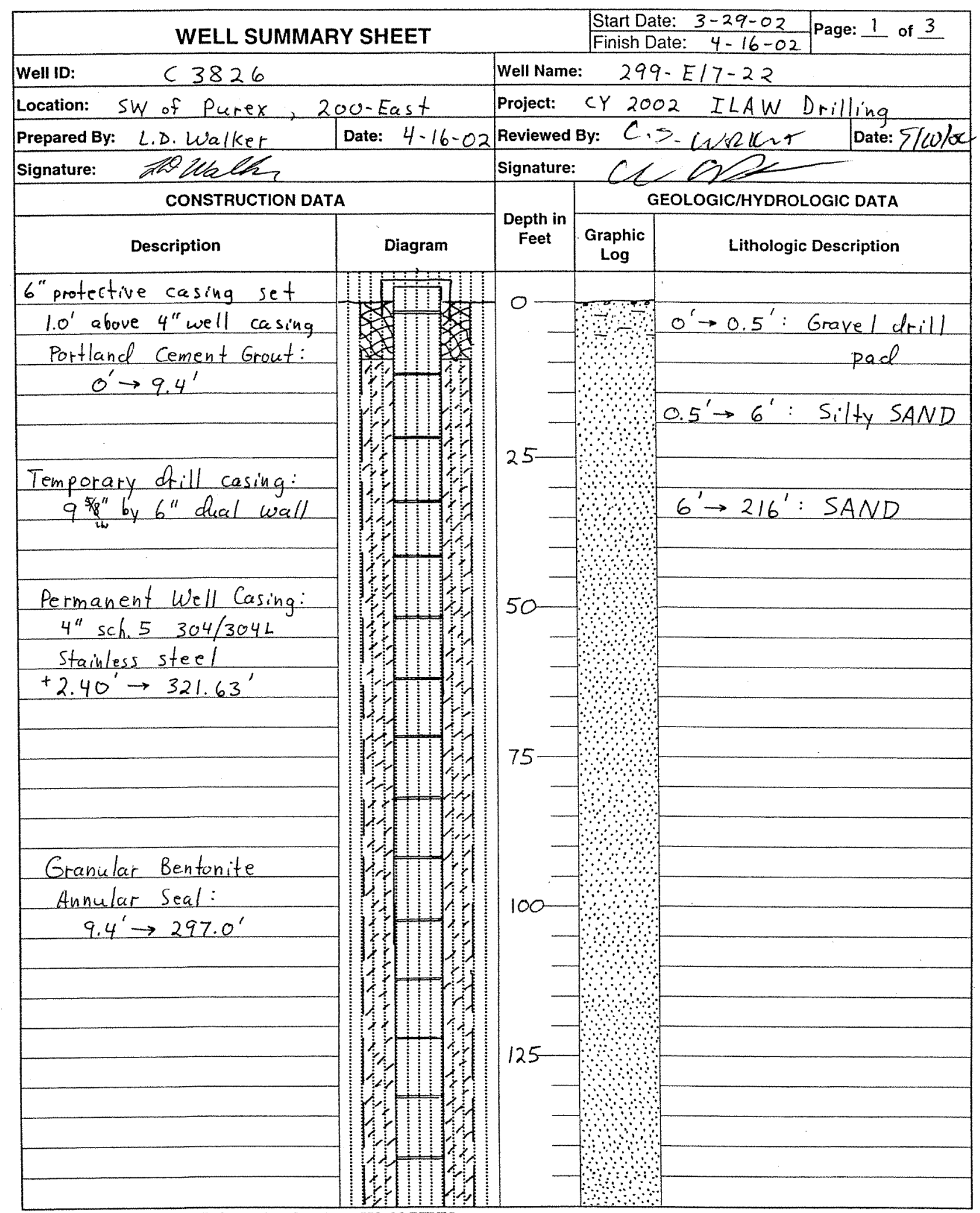

Original to: Document \& Information Services, H0-09/HWIS

Distribution by DIS: Environmental Technologies Well Coordinator, HO-02

BHI-EE-189 (02-20-2002) 


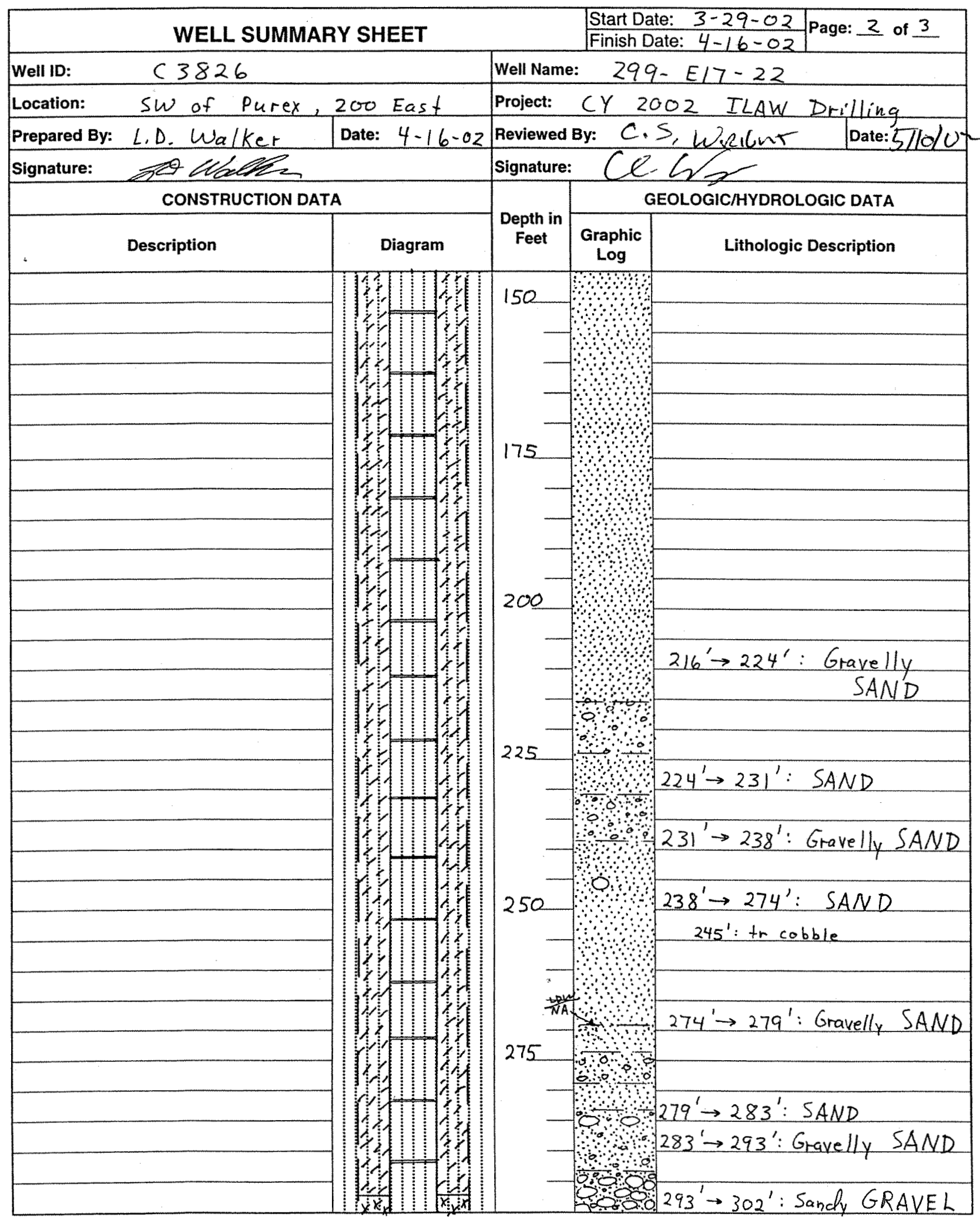

Original to: Document \& Information Services, H0-09/HWIS

Distribution by DIS: Environmental Technologies Well Coordinator, H0-02

BHI-EE-189 (02-20-2002) 


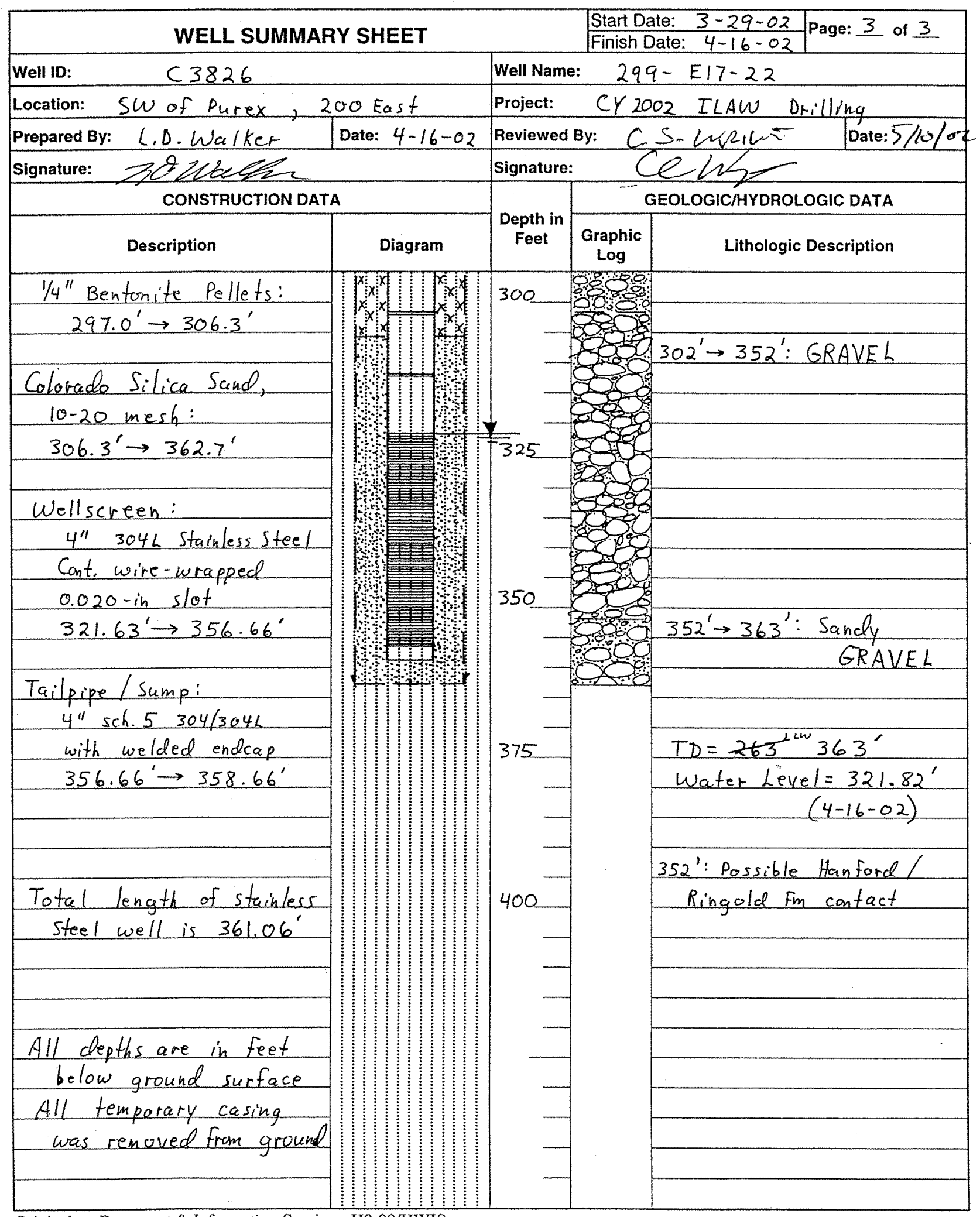

Original to: Document \& Information Services, H0-09/HWIS

Distribution by DIS: Environmental Technologies Well Coordinator, H0-02

BHI-EE-189 (02-20-2002) 


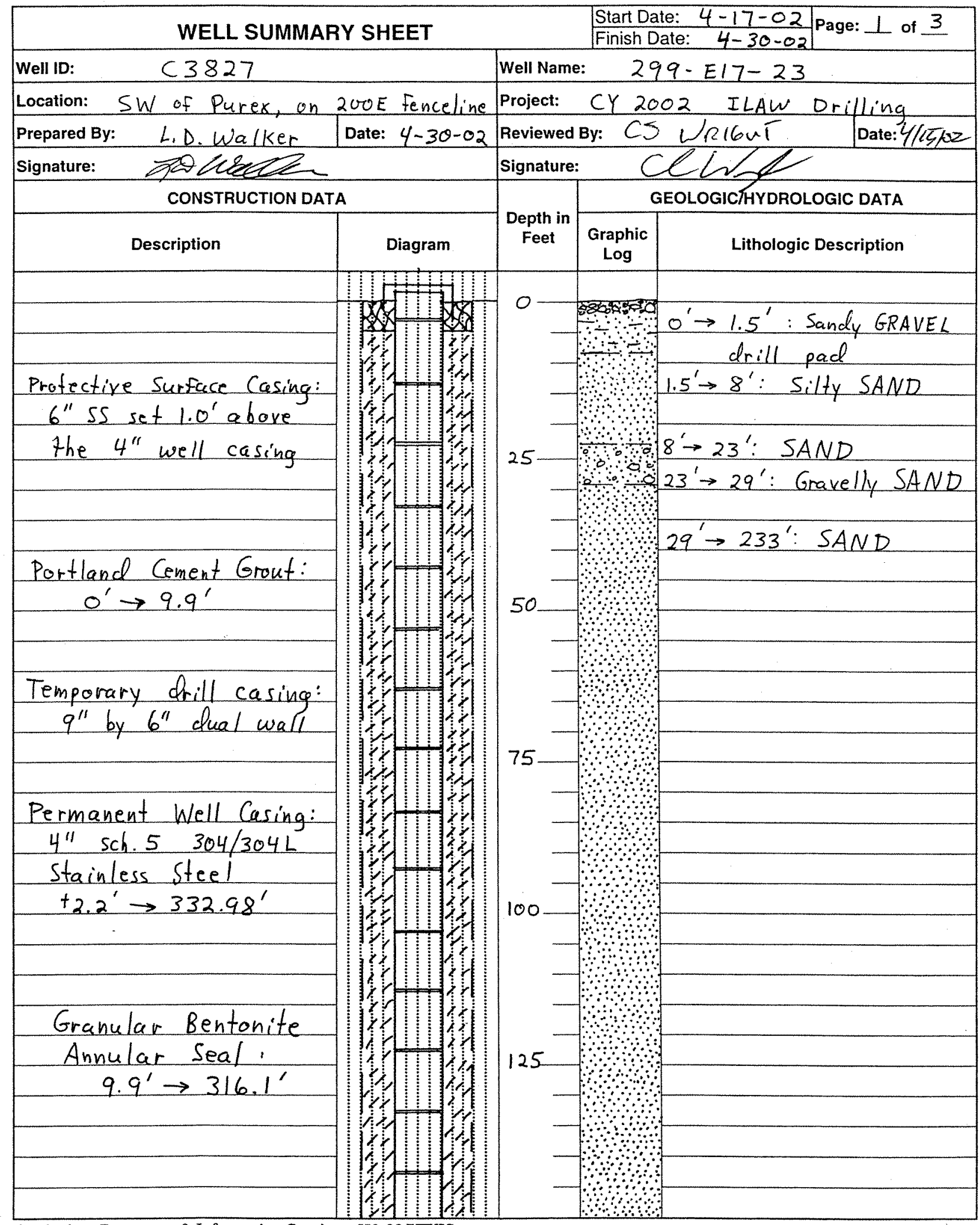

Original to: Document \& Information Services, H0-09/HWIS

Distribution by DIS: Environmental Technologies Well Coordinator, H0-02

BHI-EE-189 (02-20-2002) 


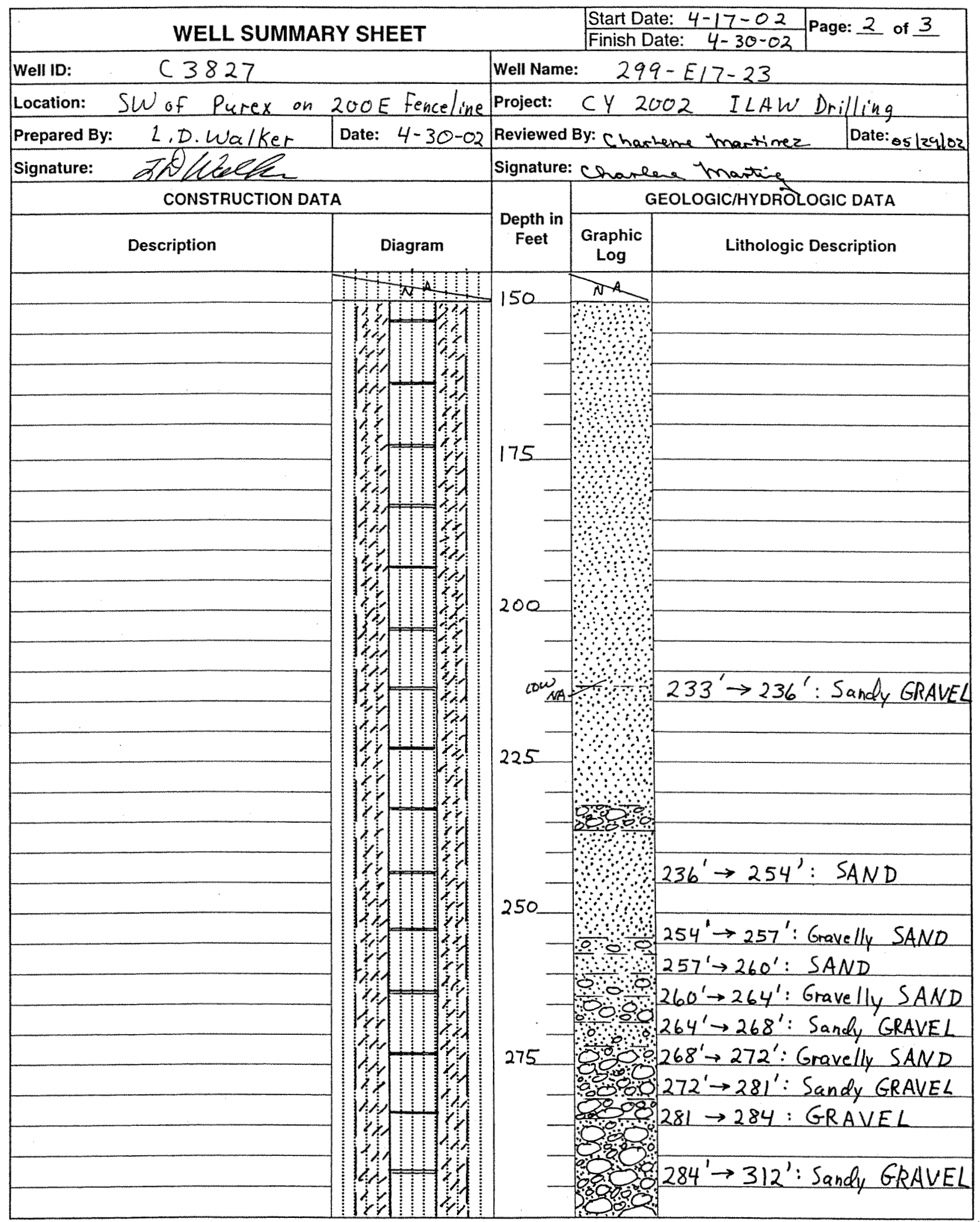

Original to: Document \& Information Services, H0-09/HWIS

Distribution by DIS: Environmental Technologies Well Coordinator, H0-02

BHI-EE-189 (02-20-2002) 


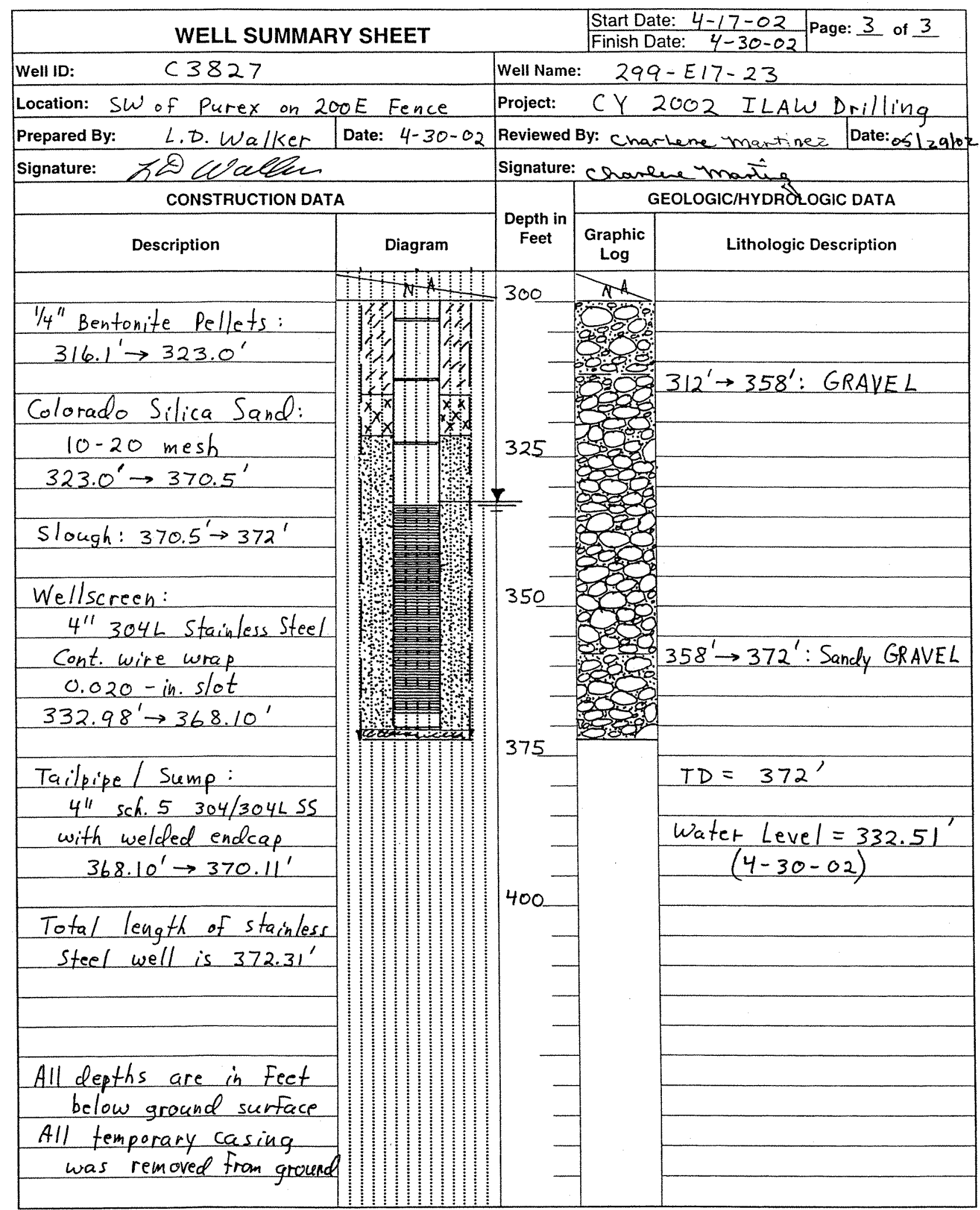

Original to: Document \& Information Services, H0-09/HWIS

Distribution by DIS: Environmental Technologies Well Coordinator, H0-02

BHI-EE-189 (02-20-2002) 


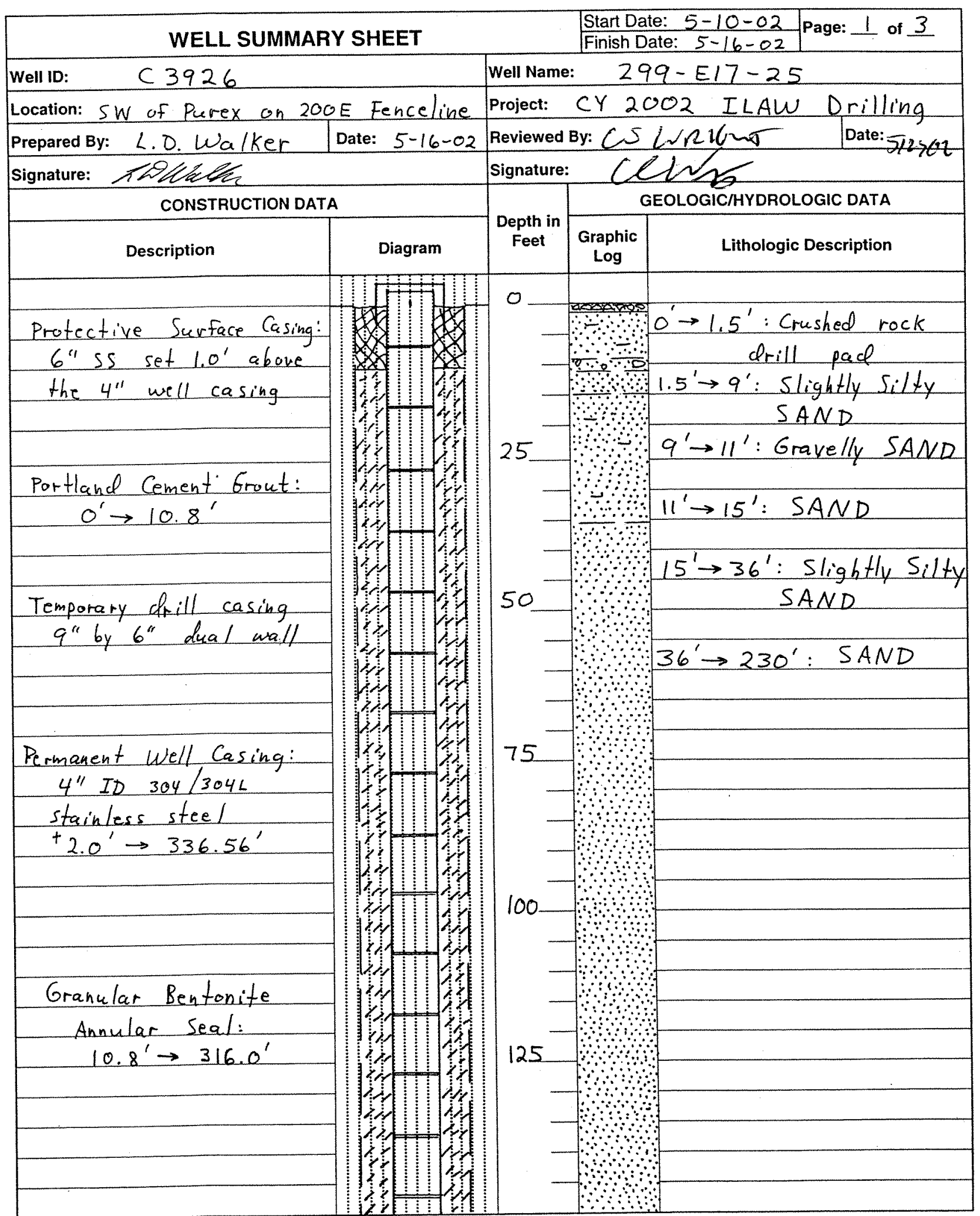

Original to: Document \& Information Services, H0-09/HWIS

Distribution by DIS: Environmental Technologies Well Coordinator, $\mathrm{HO}-02$

BHI-EE-189 (02-20-2002) 


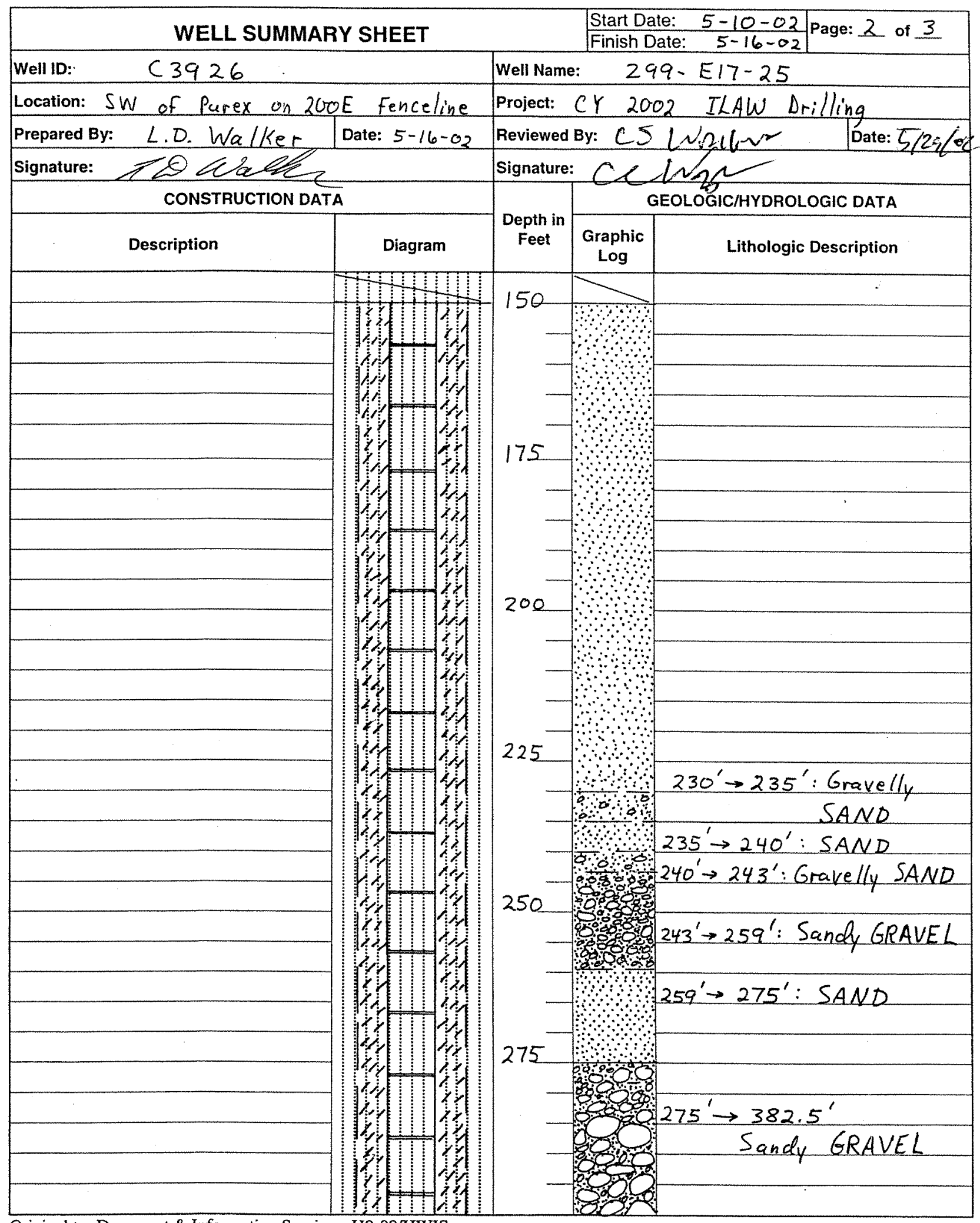

Original to: Document \& Information Services, H0-09/HWIS

Distribution by DIS: Environmental Technologies Well Coordinator, H0-02

BHI-EE-189 (02-20-2002) 


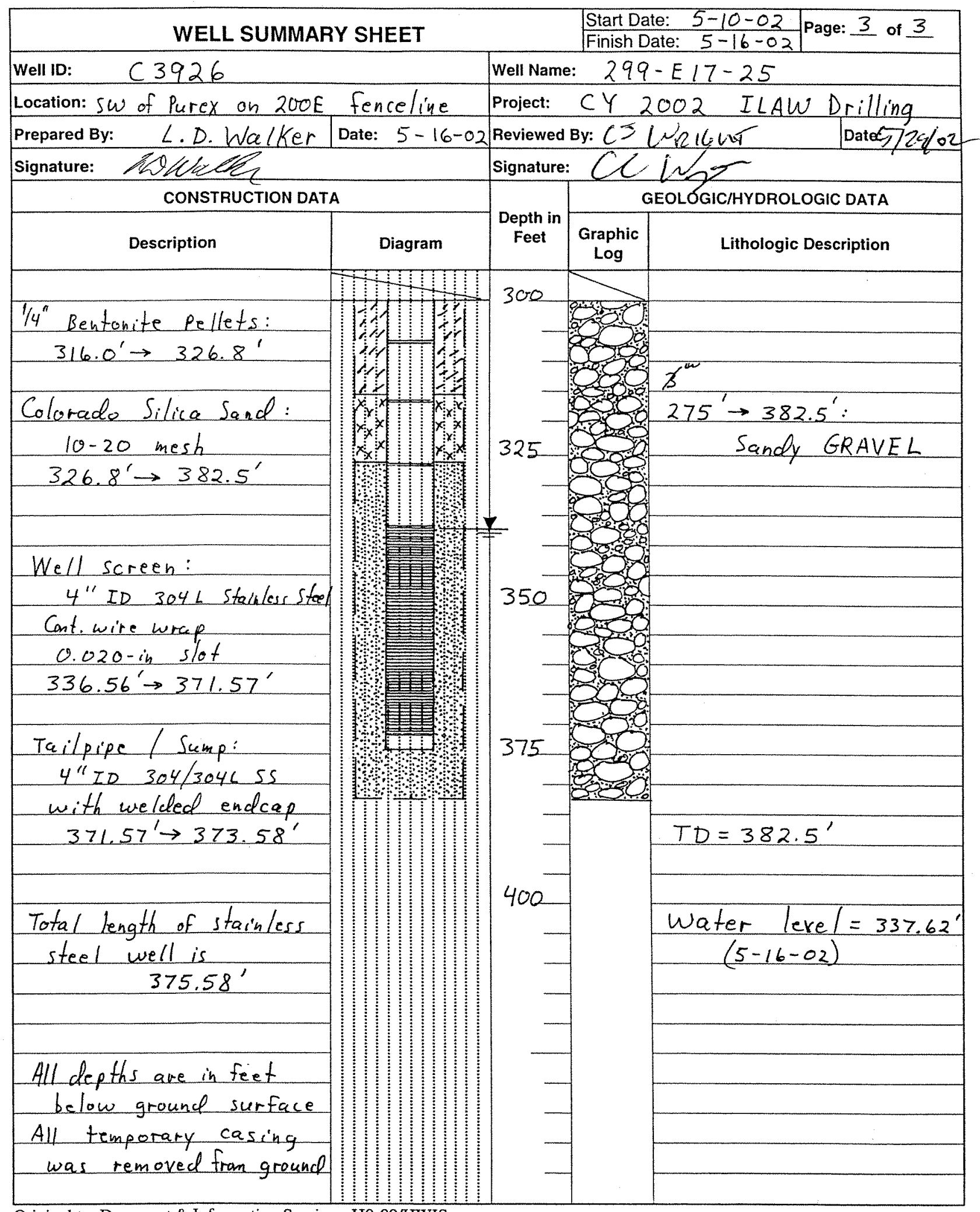

Original to: Document \& Information Services, H0-09/HWIS

Distribution by DIS: Environmental Technologies Well Coordinator, H0-02

BHI-EE-189 (02-20-2002) 


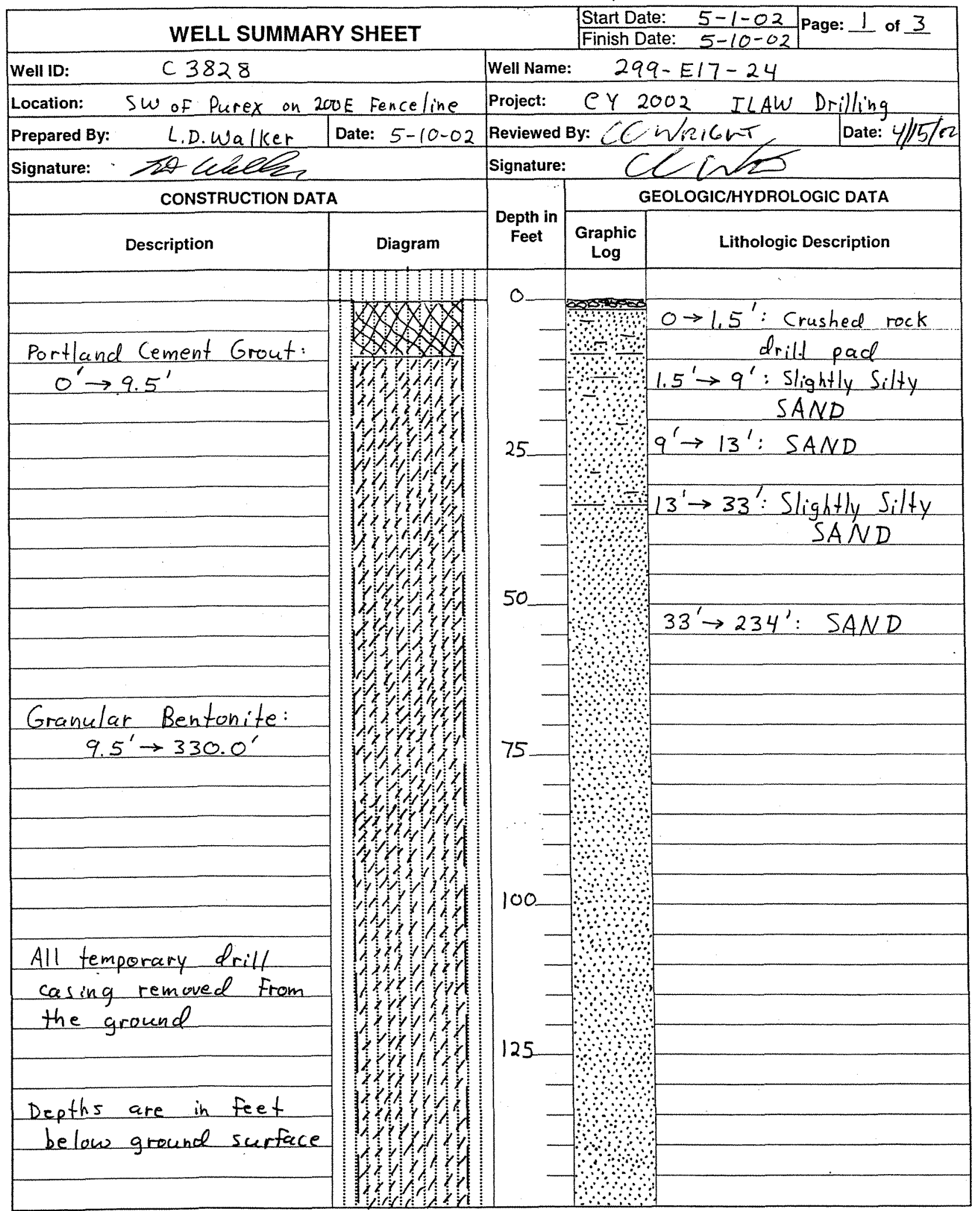

Original to: Document \& Information Services, H0-09/HWIS

Distribution by DIS: Environmental Technologies Well Coordinator, H0-02

BHI-EE-189 (02-20-2002) 


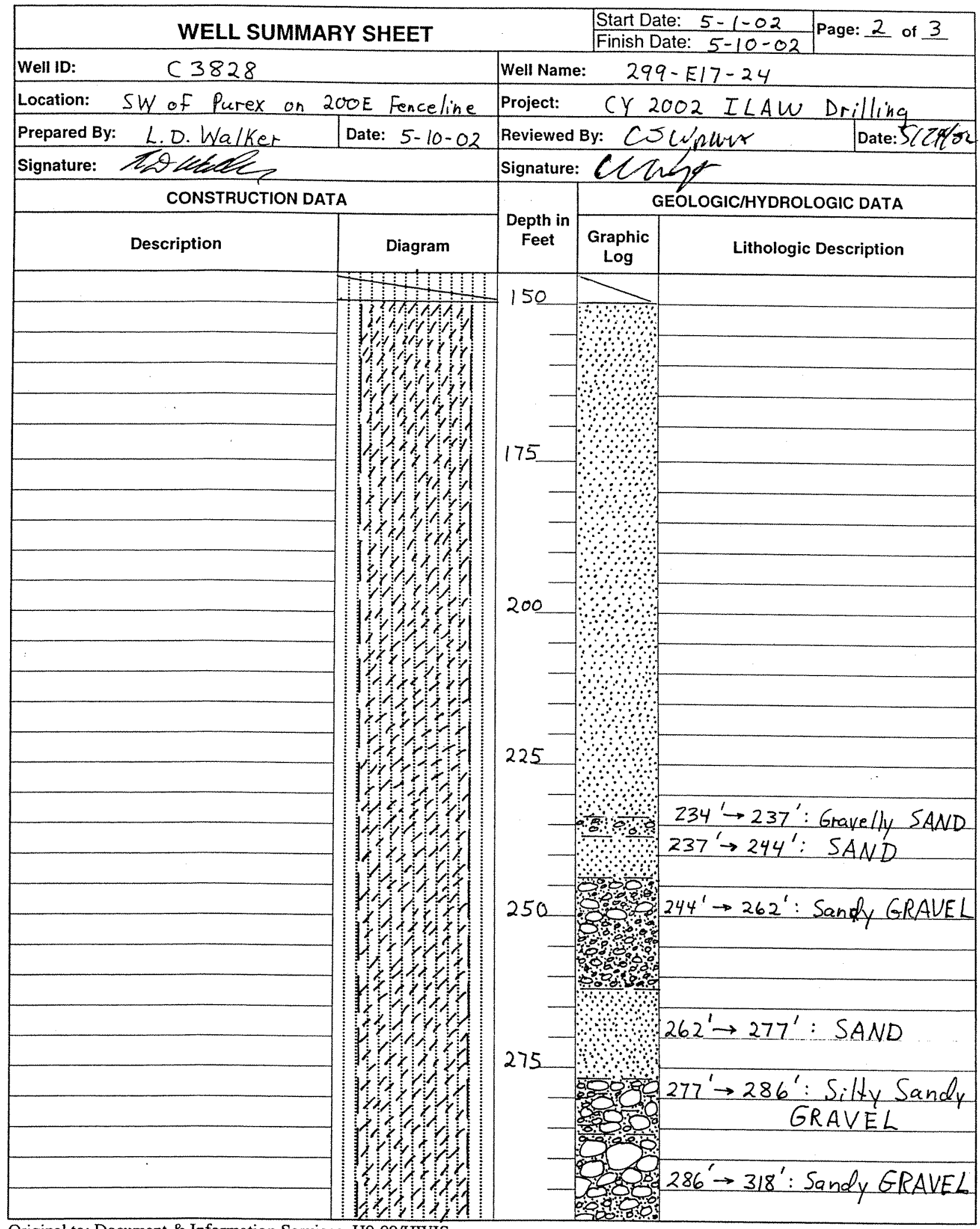

Original to: Document \& Information Services, H0-09/HWIS

Distribution by DIS: Environmental Technologies Well Coordinator, H0-02

BHI-EE-189 (02-20-2002) 


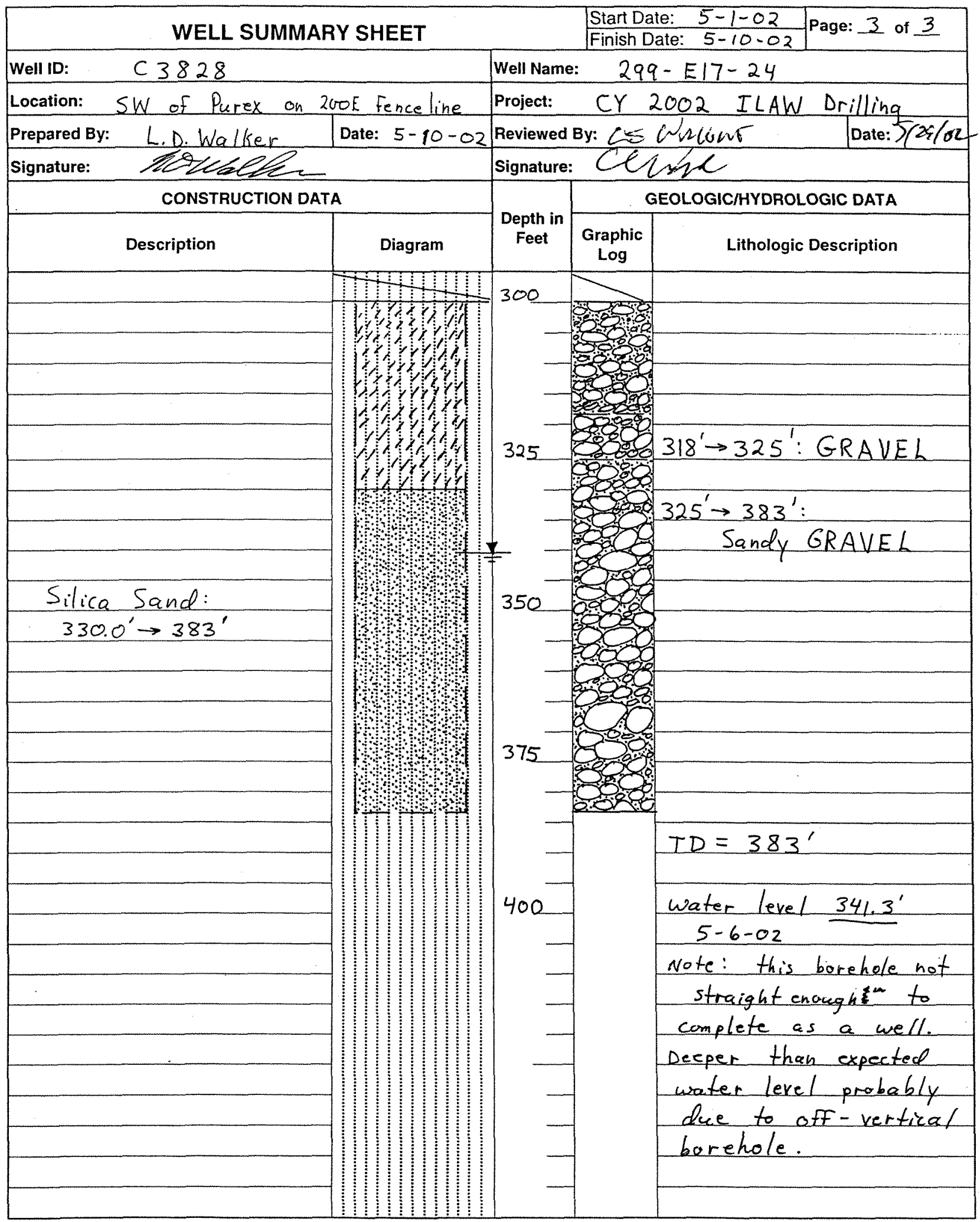

Original to: Document \& Information Services, H0-09/HWIS

Distribution by DIS: Environmental Technologies Well Coordinator, H0-02

BHI-EE-189 (02-20-2002) 
APPENDIX B

\section{BOREHOLE LOG SHEETS}


BHI-01647

Rev. 0 


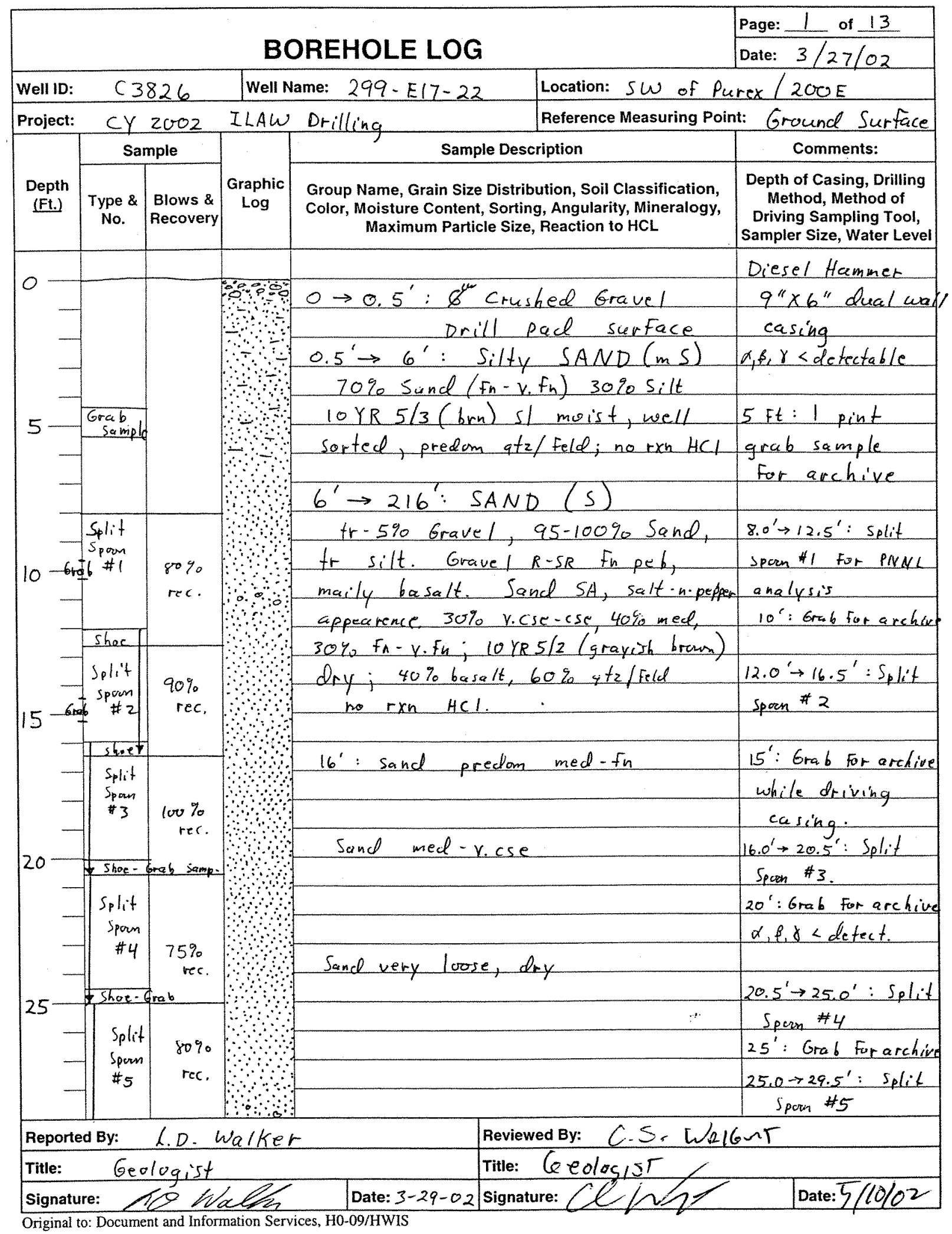

BHI-EE-183 (02-20-2002) 


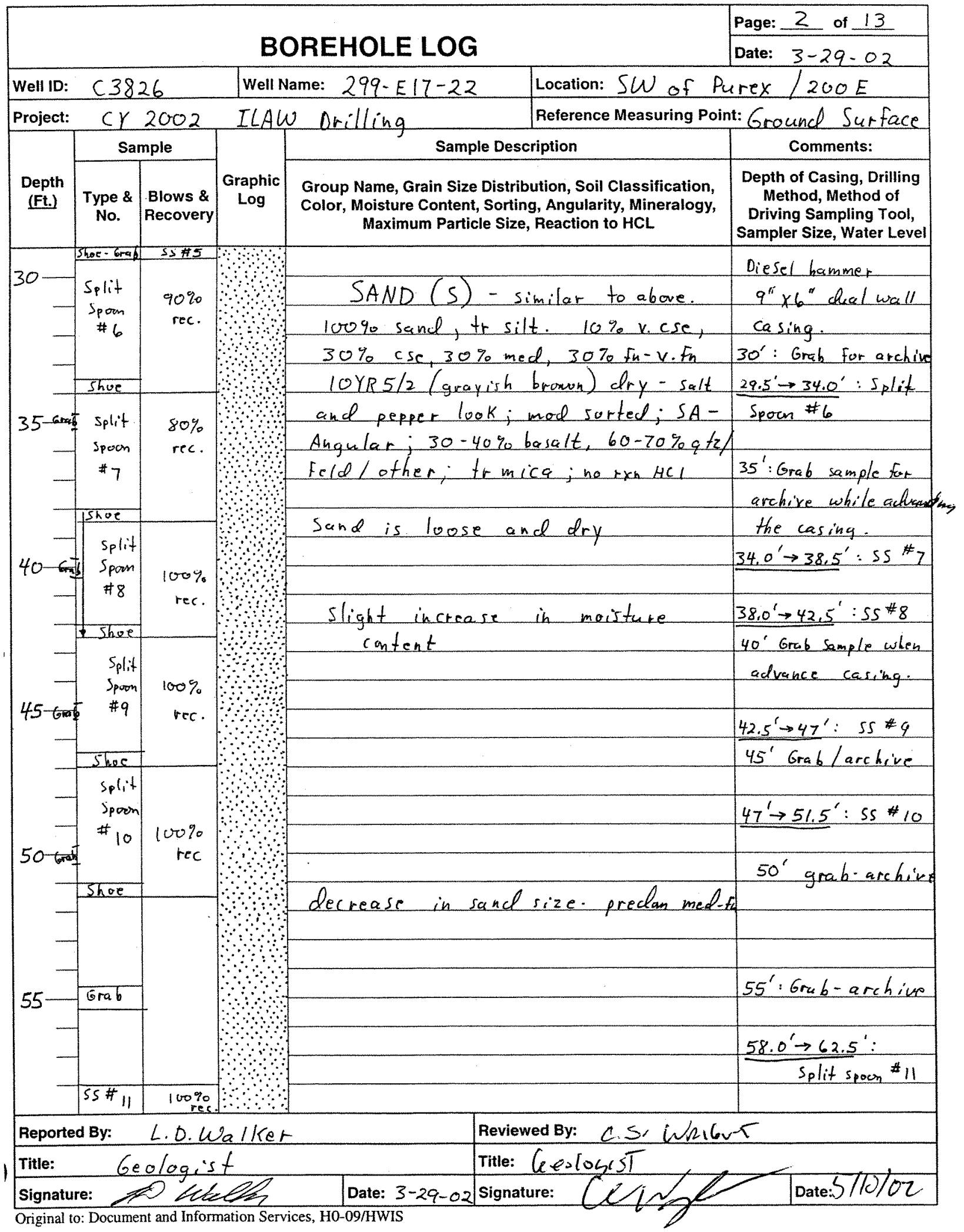

BHI-EE-183 (02-20-2002) 


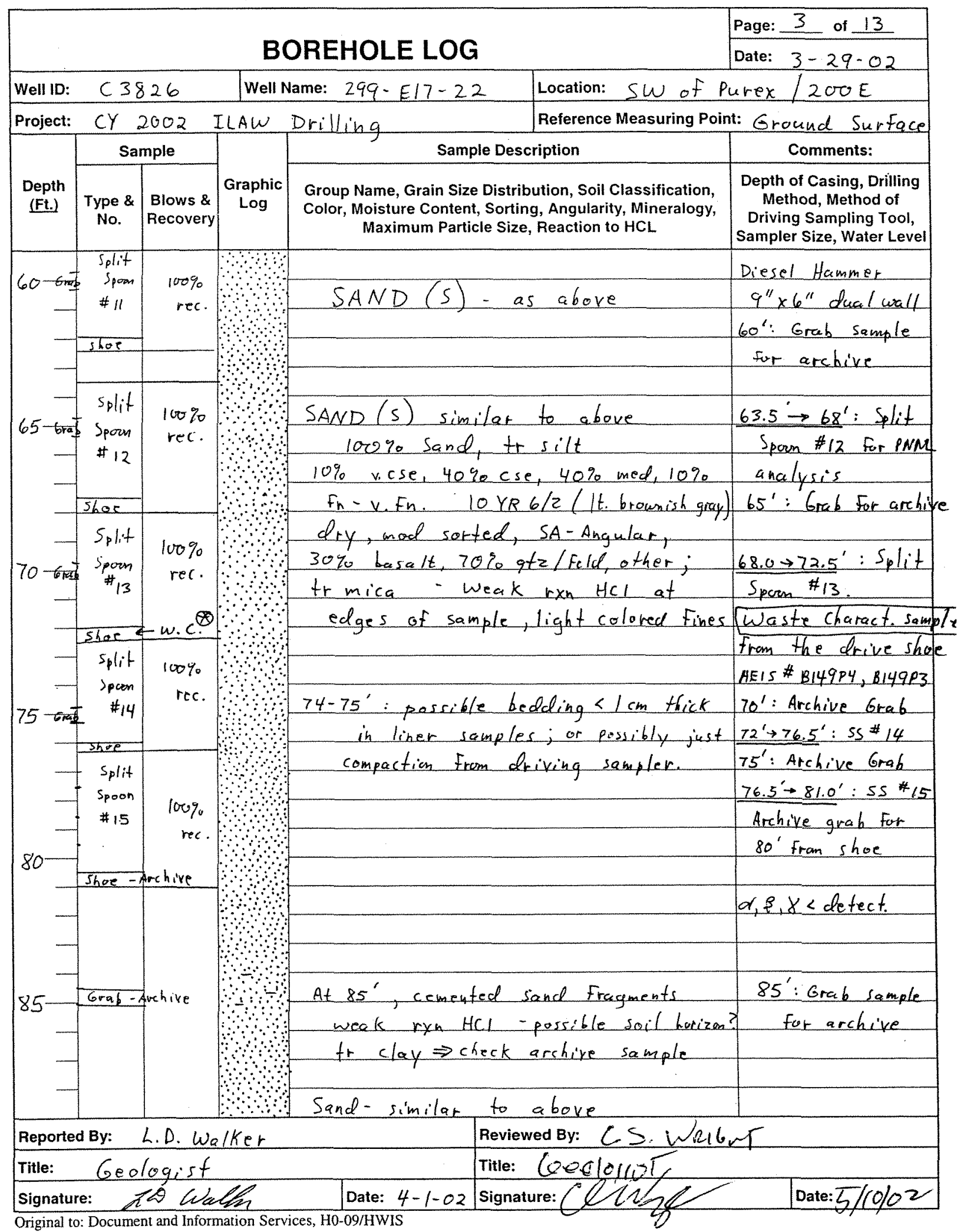

BHI-EE-183 (02-20-2002) 


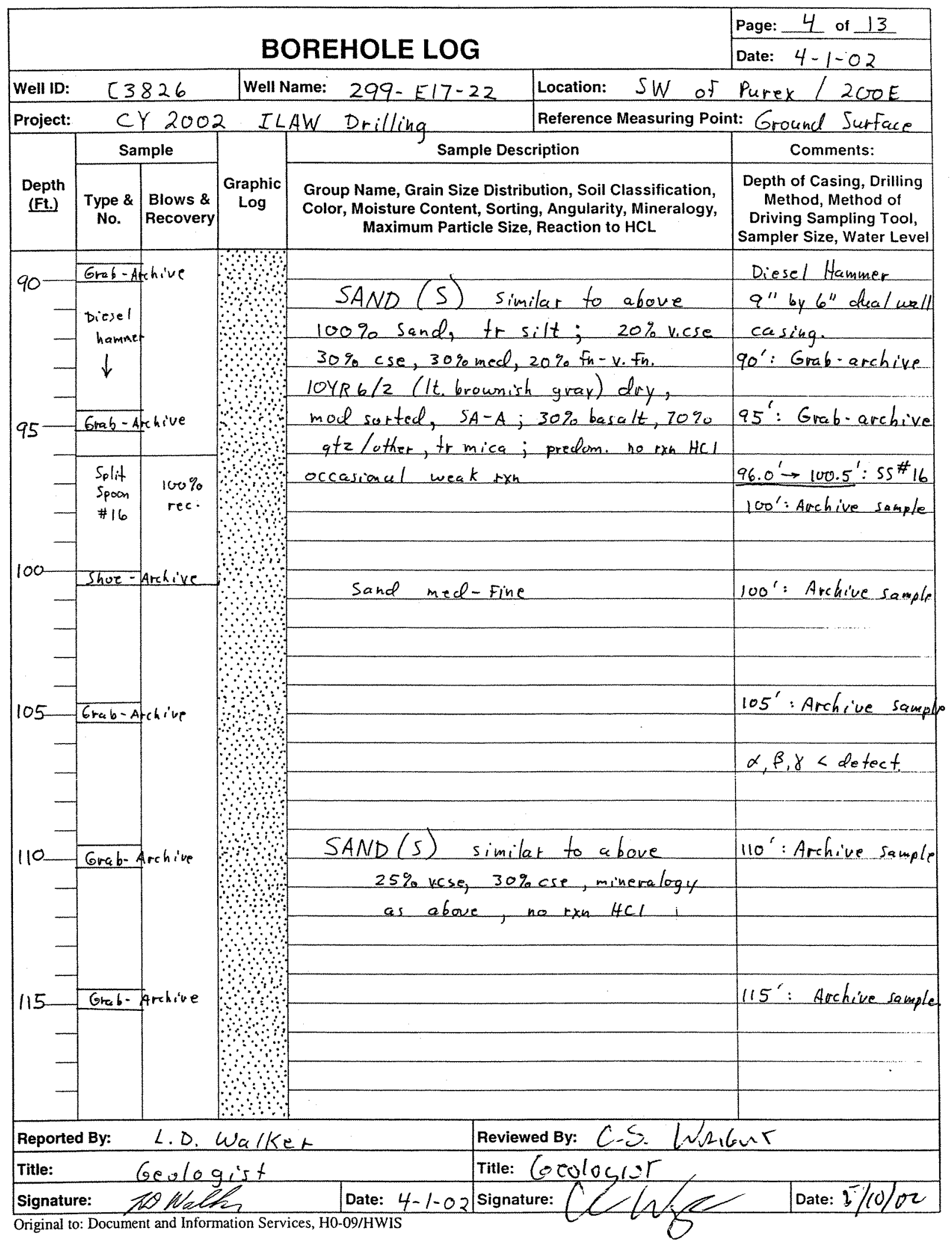

BHI-EE-183 (02-20-2002) 


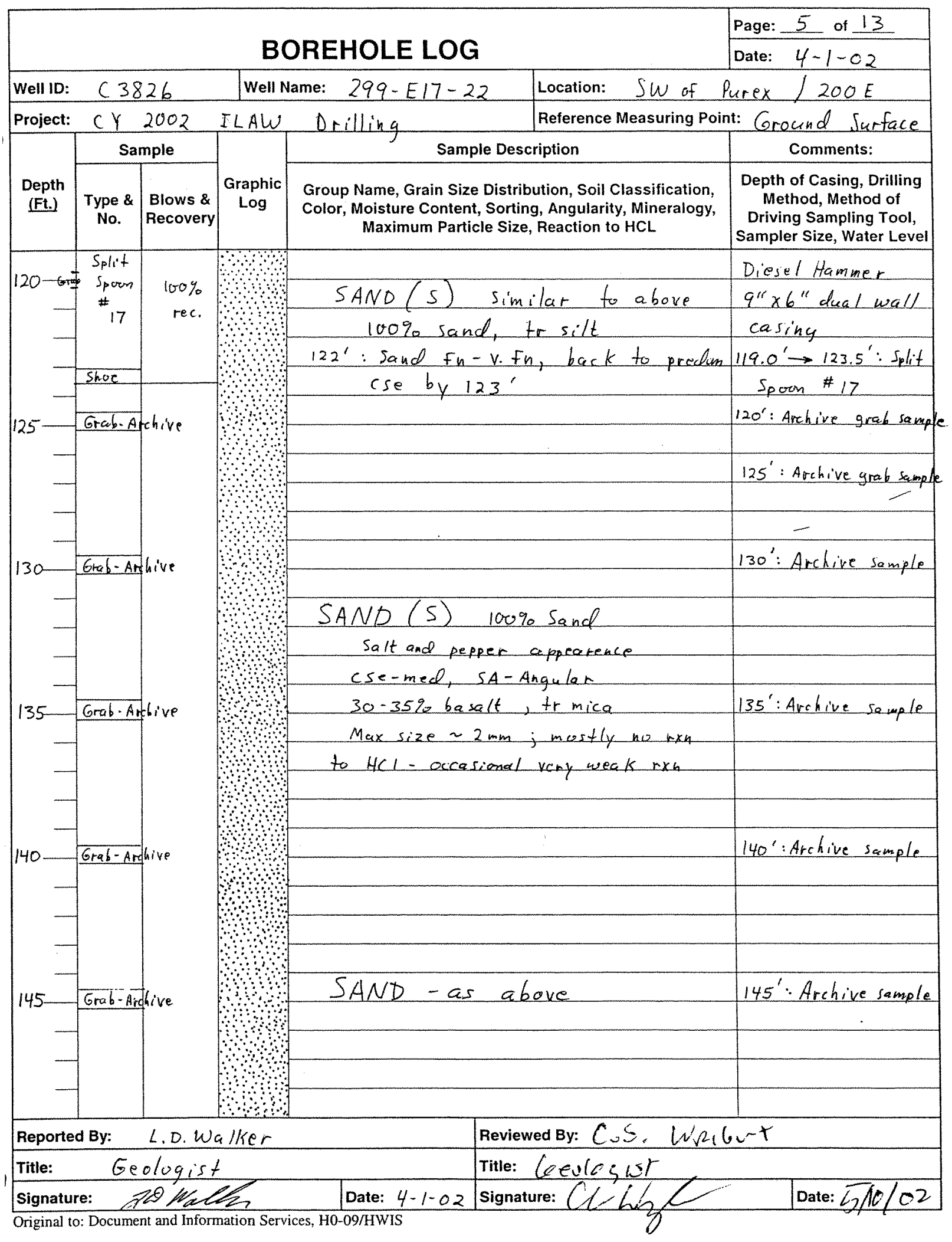

BHI-EE-183 (02-20-2002) 


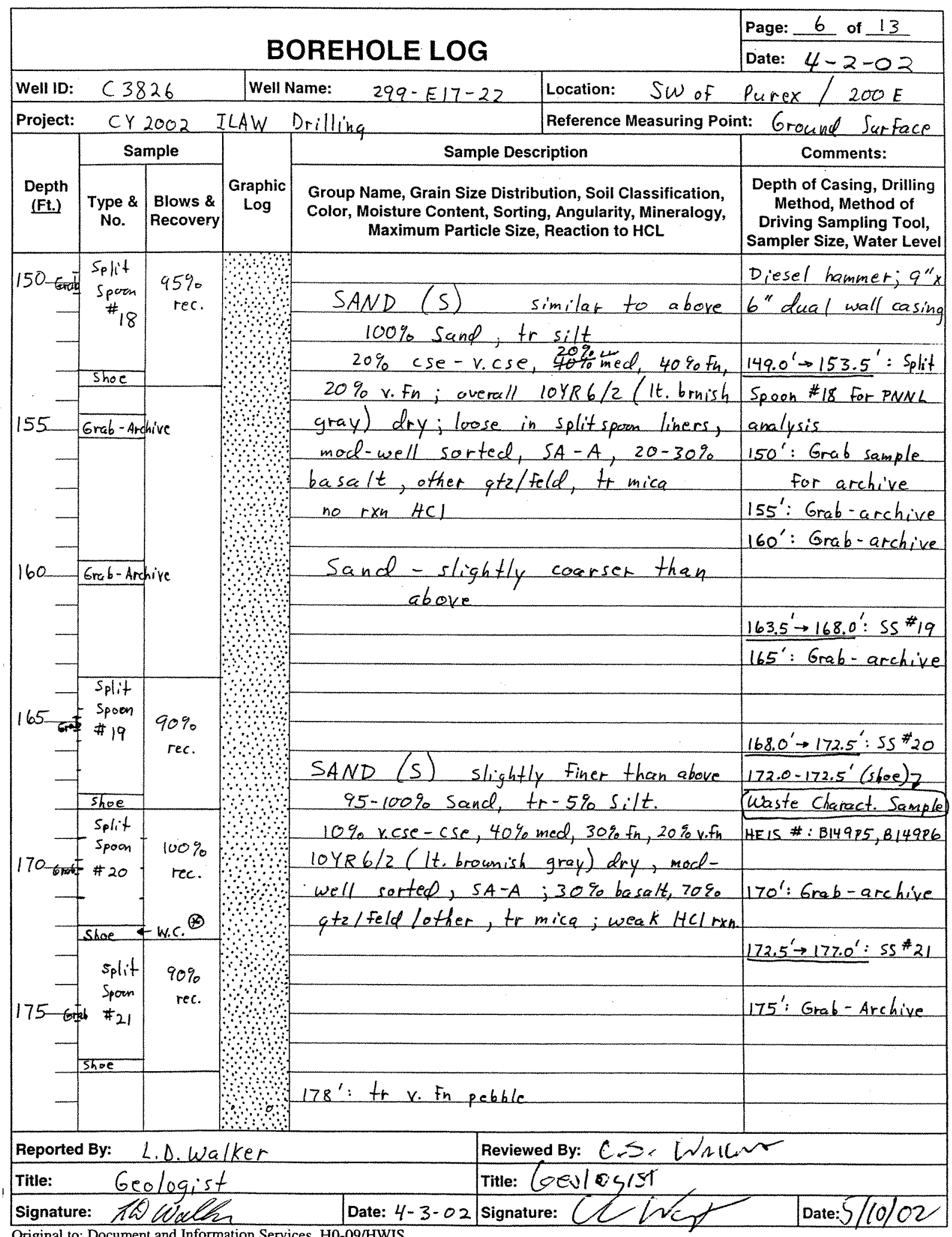

Original to: Document and Information Services, H0-09/HWIS

BHI-EE-183 (02-20-2002) 


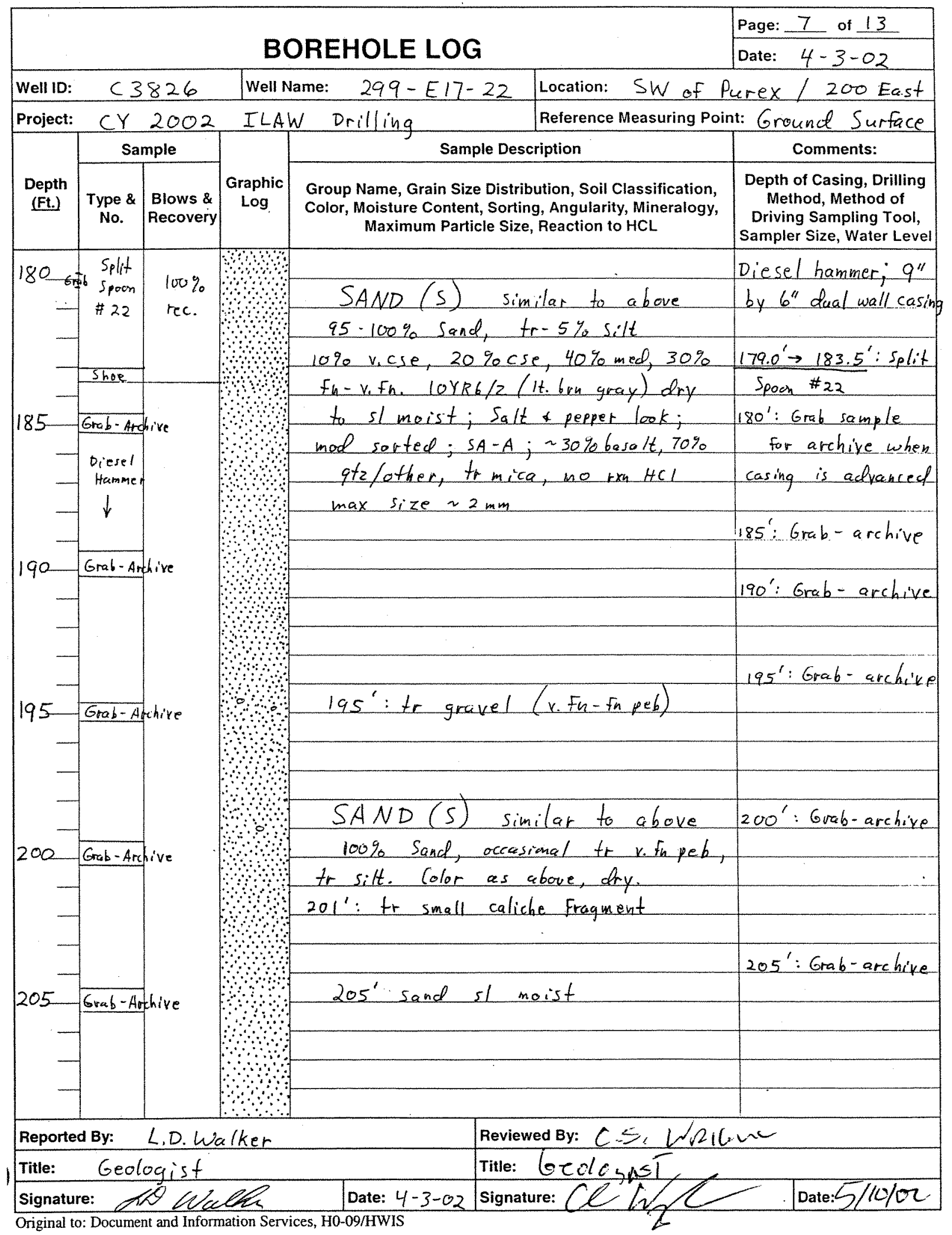

BHI-EE-183 (02-20-2002) 


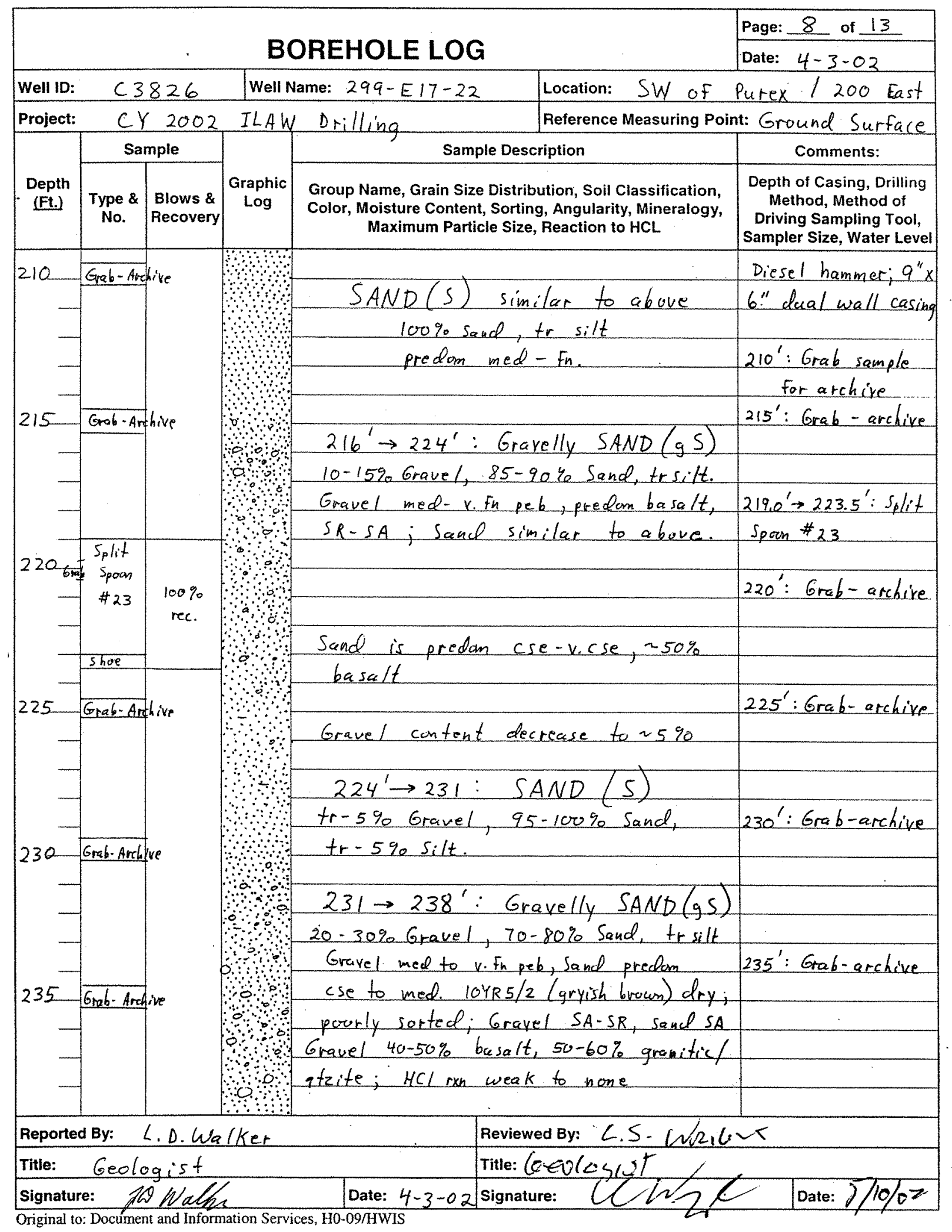

BHI-EE-183 (02-20-2002) 


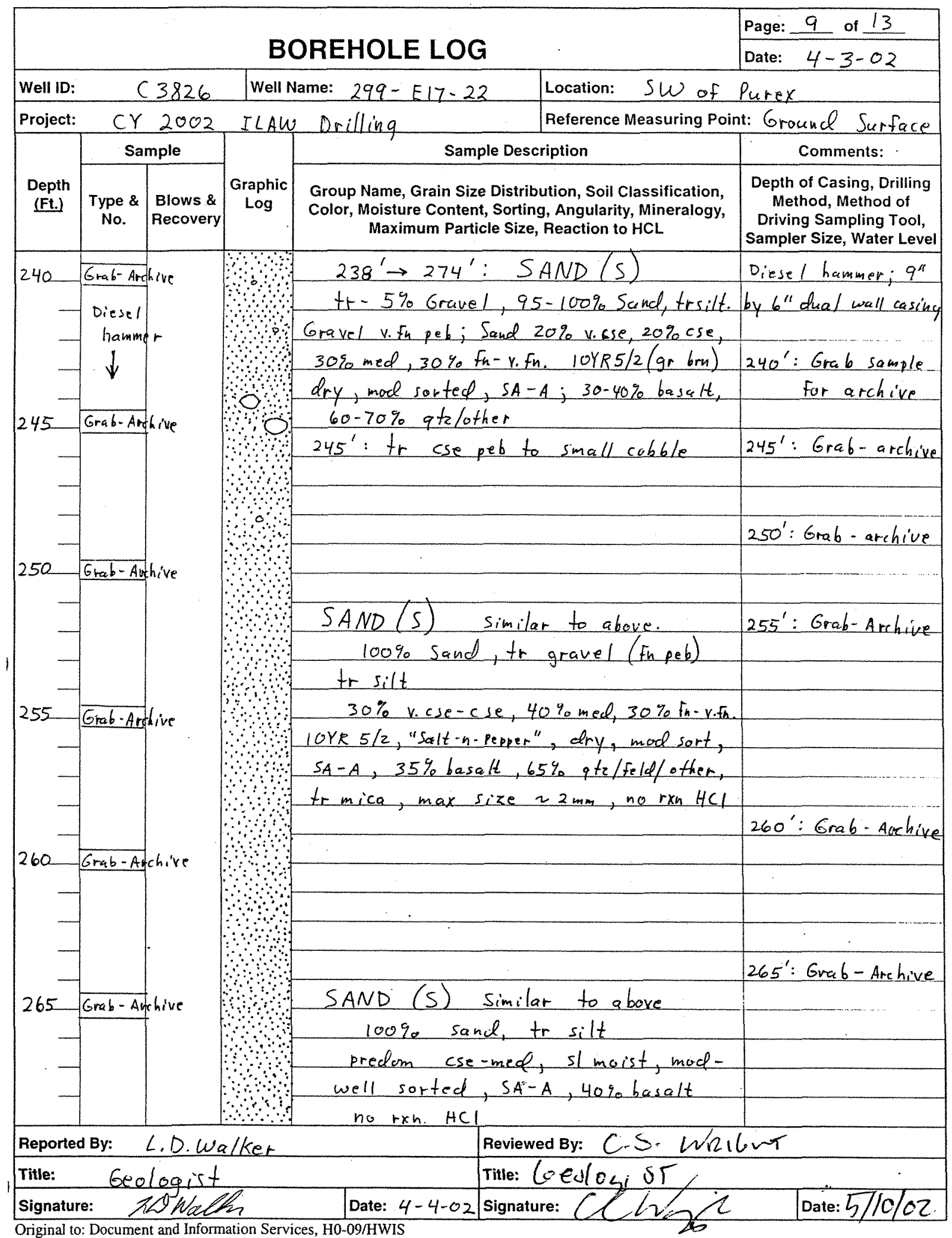

BHI-EE-183 (02-20-2002) 


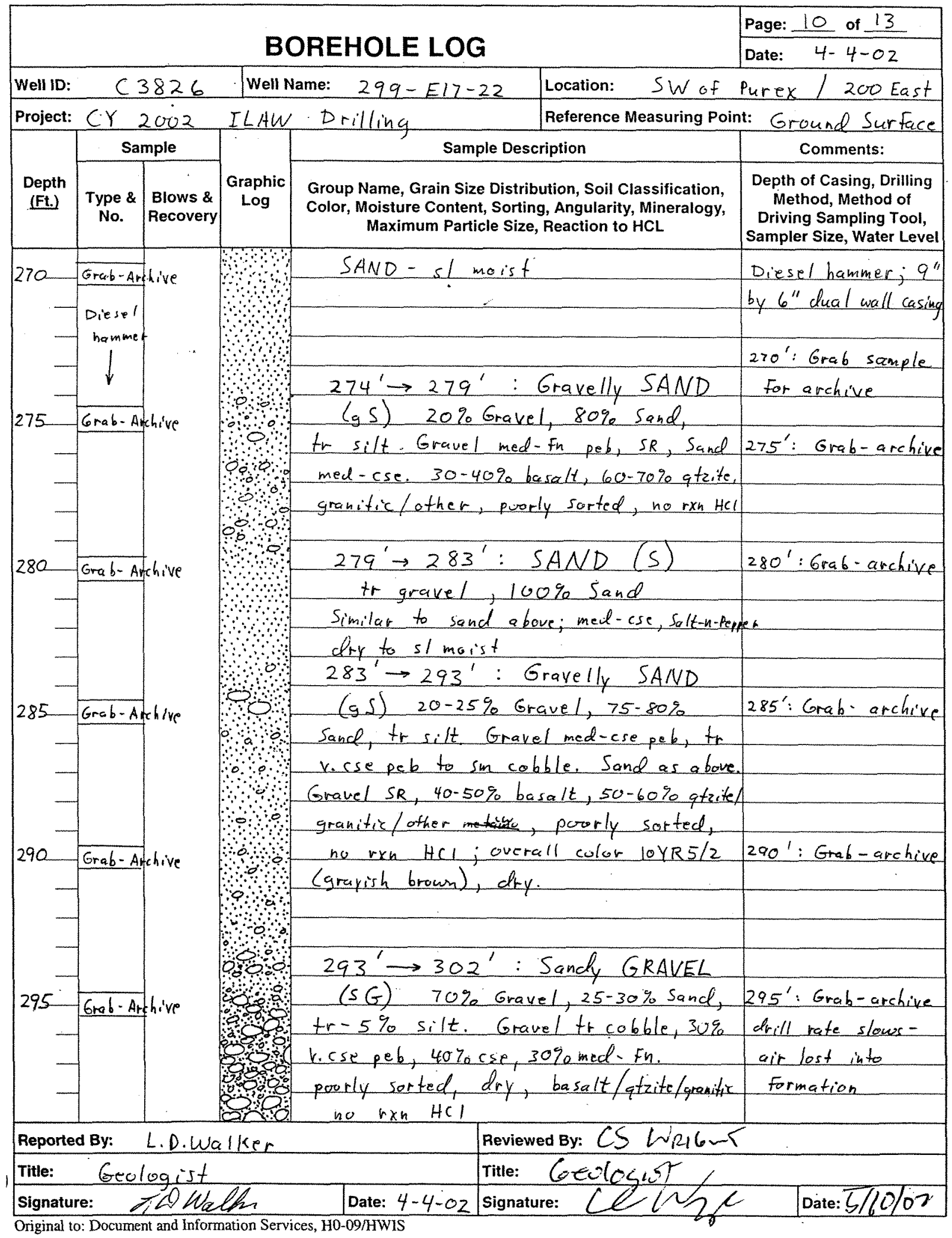

BHI-EE-183 (02-20-2002) 


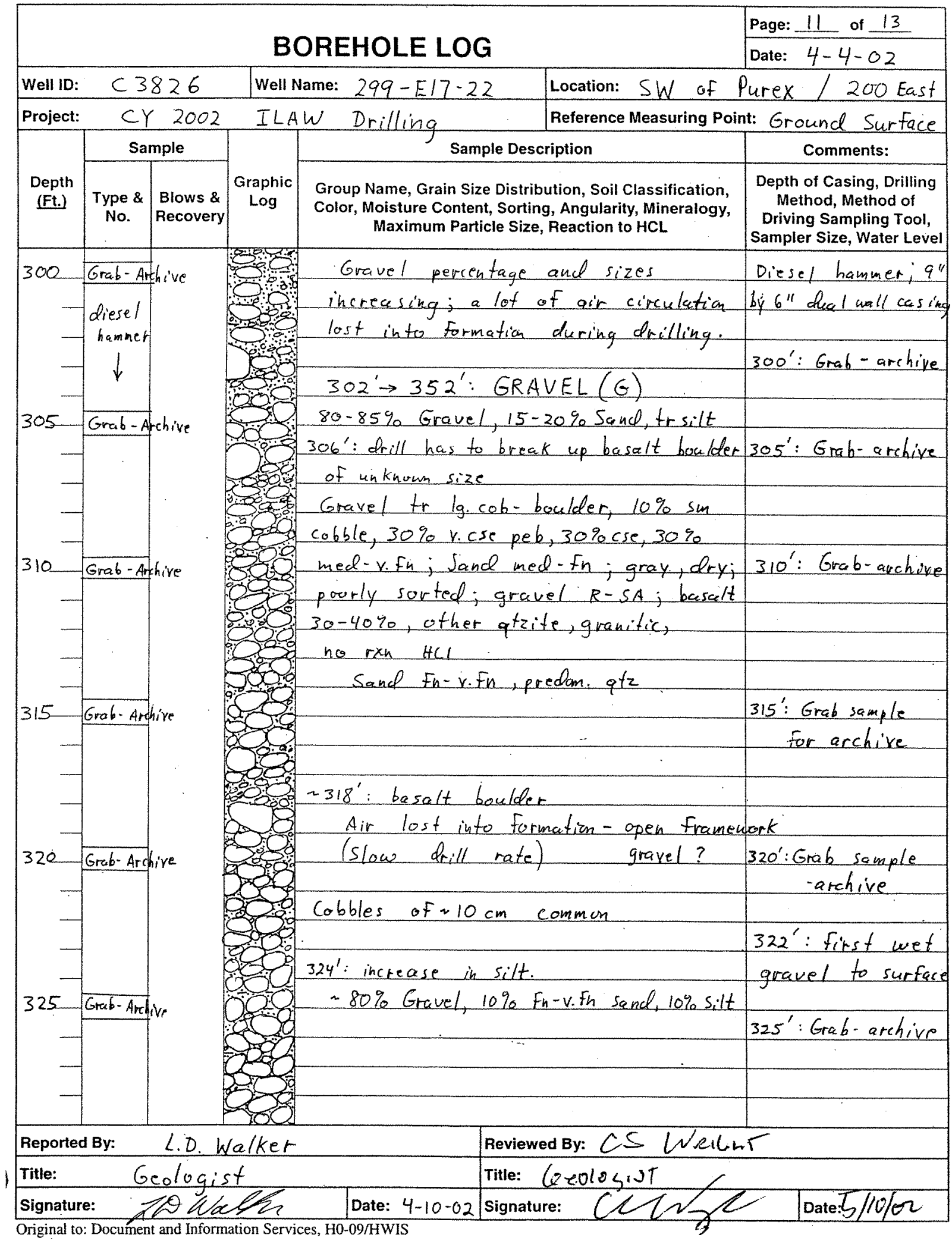

BHI-EE-183 (02-20-2002) 


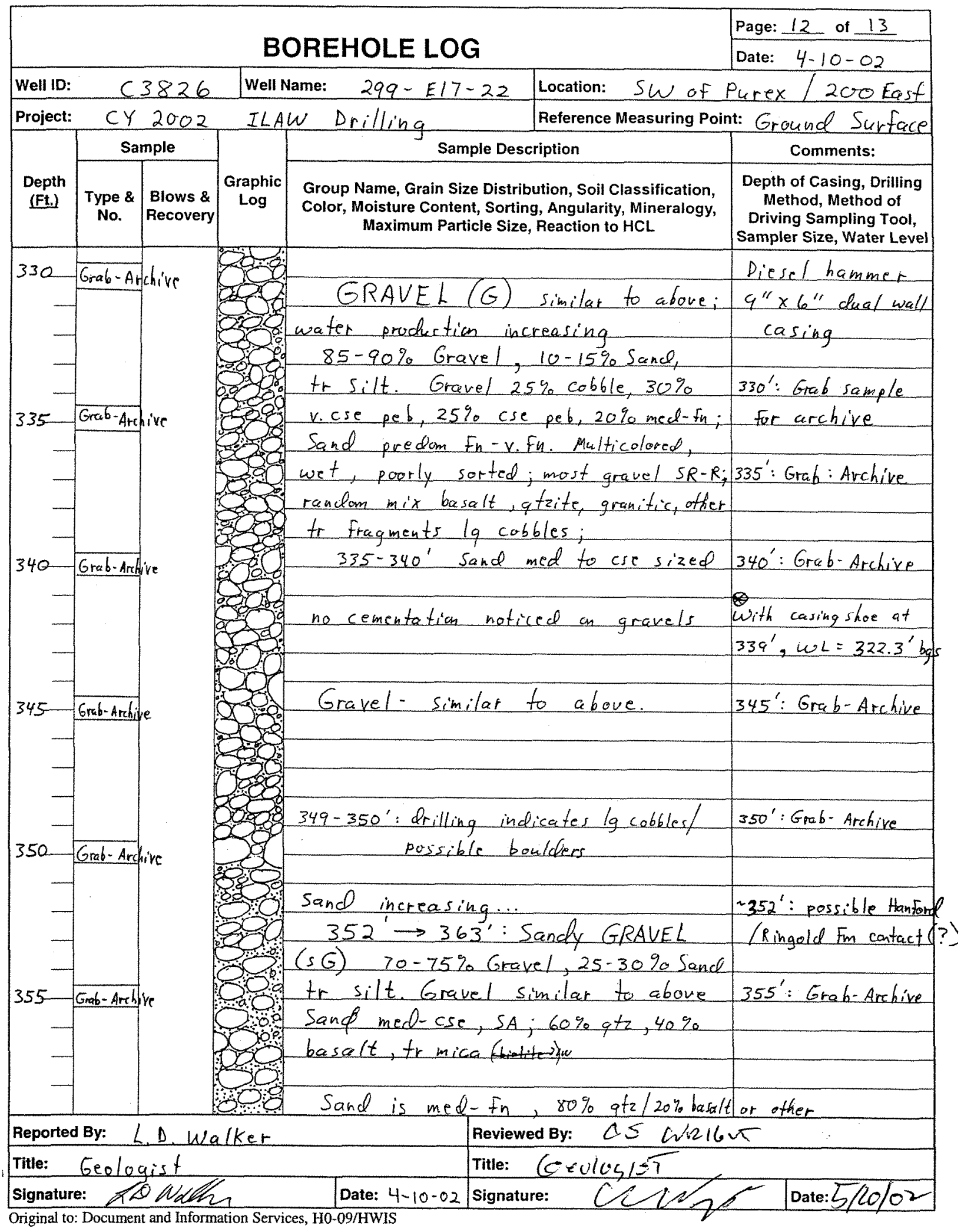

BHI-EE-183 (02-20-2002) 


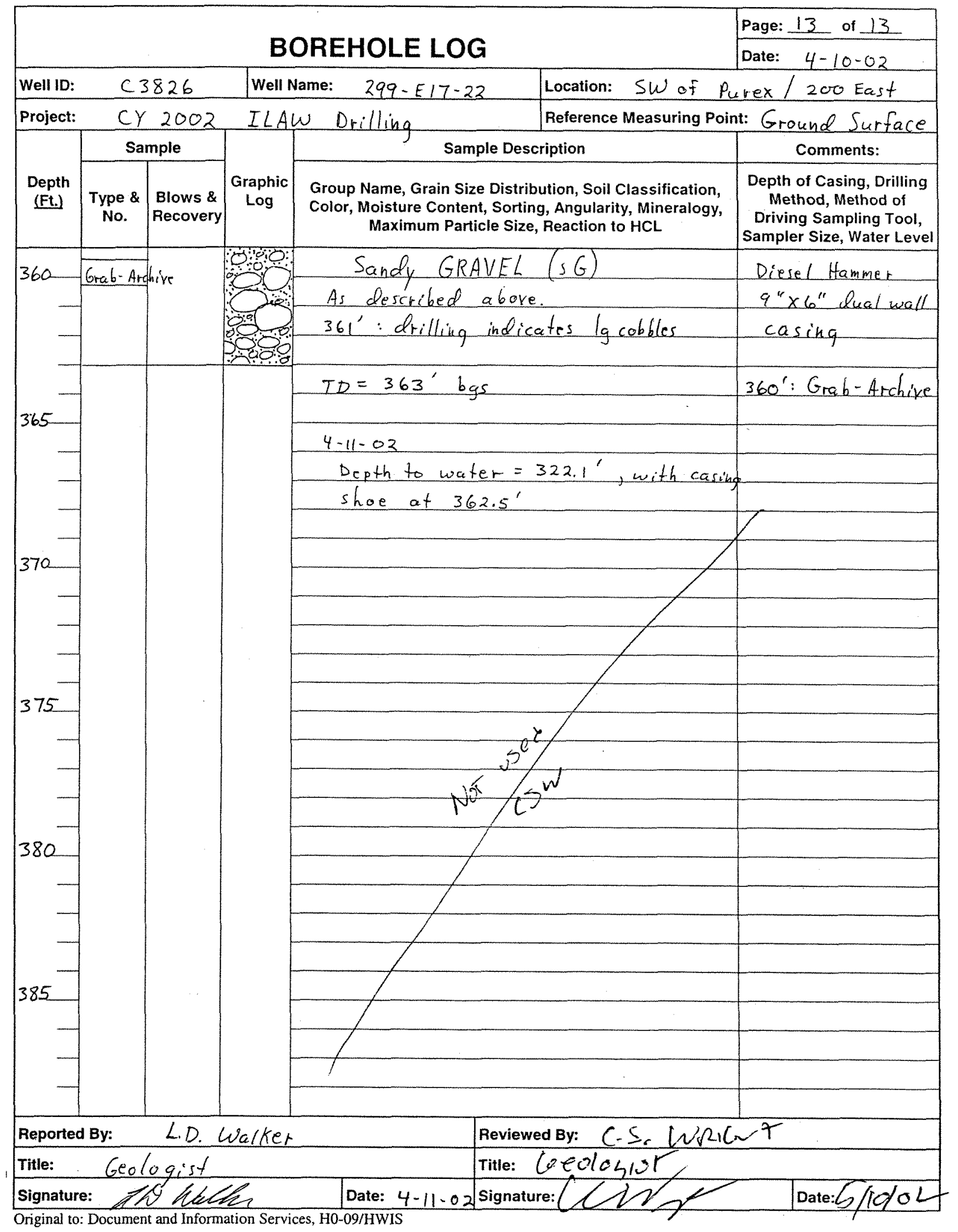

BHI-EE-183 (02-20-2002) 


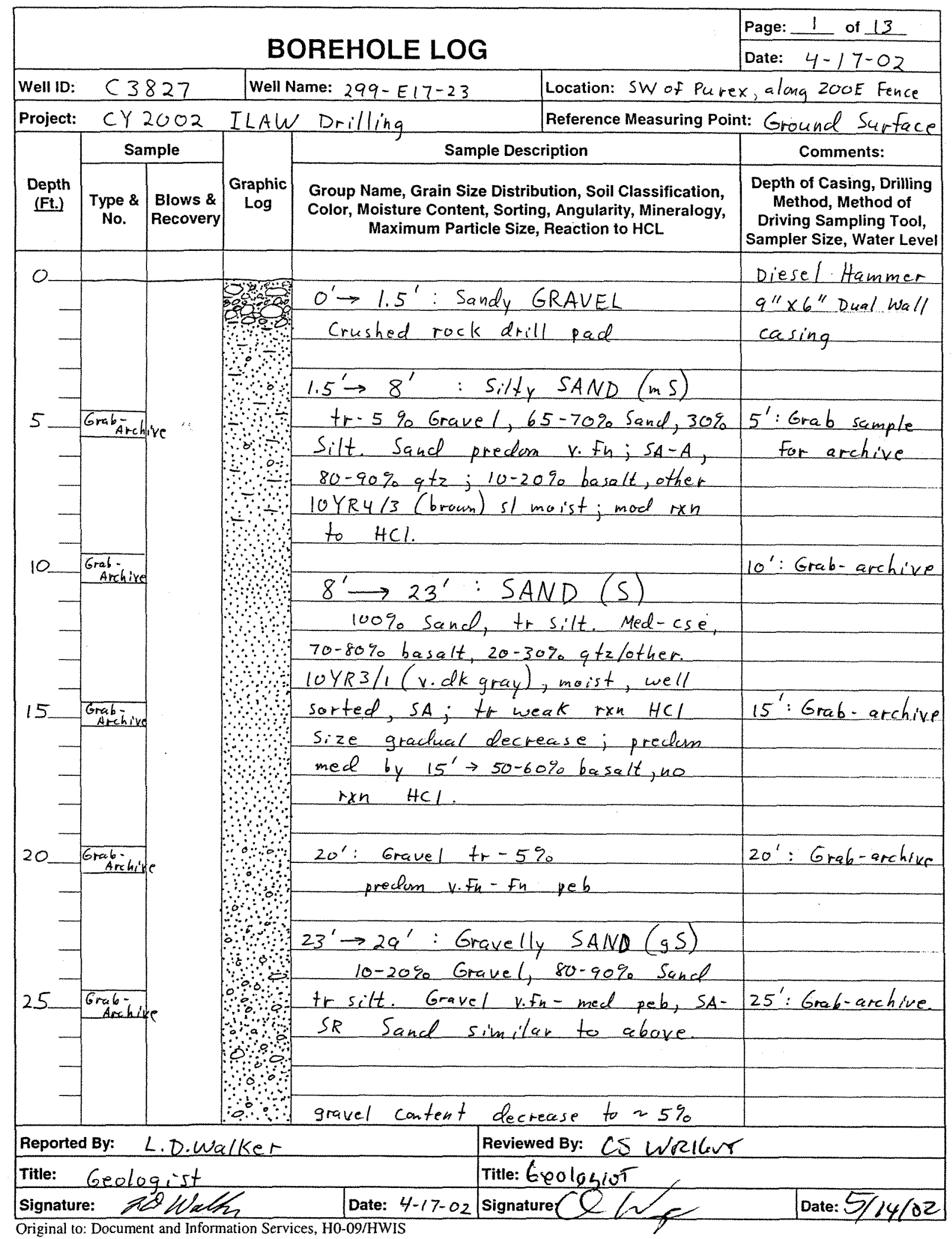

BHI-EE-183 (02-20-2002) 


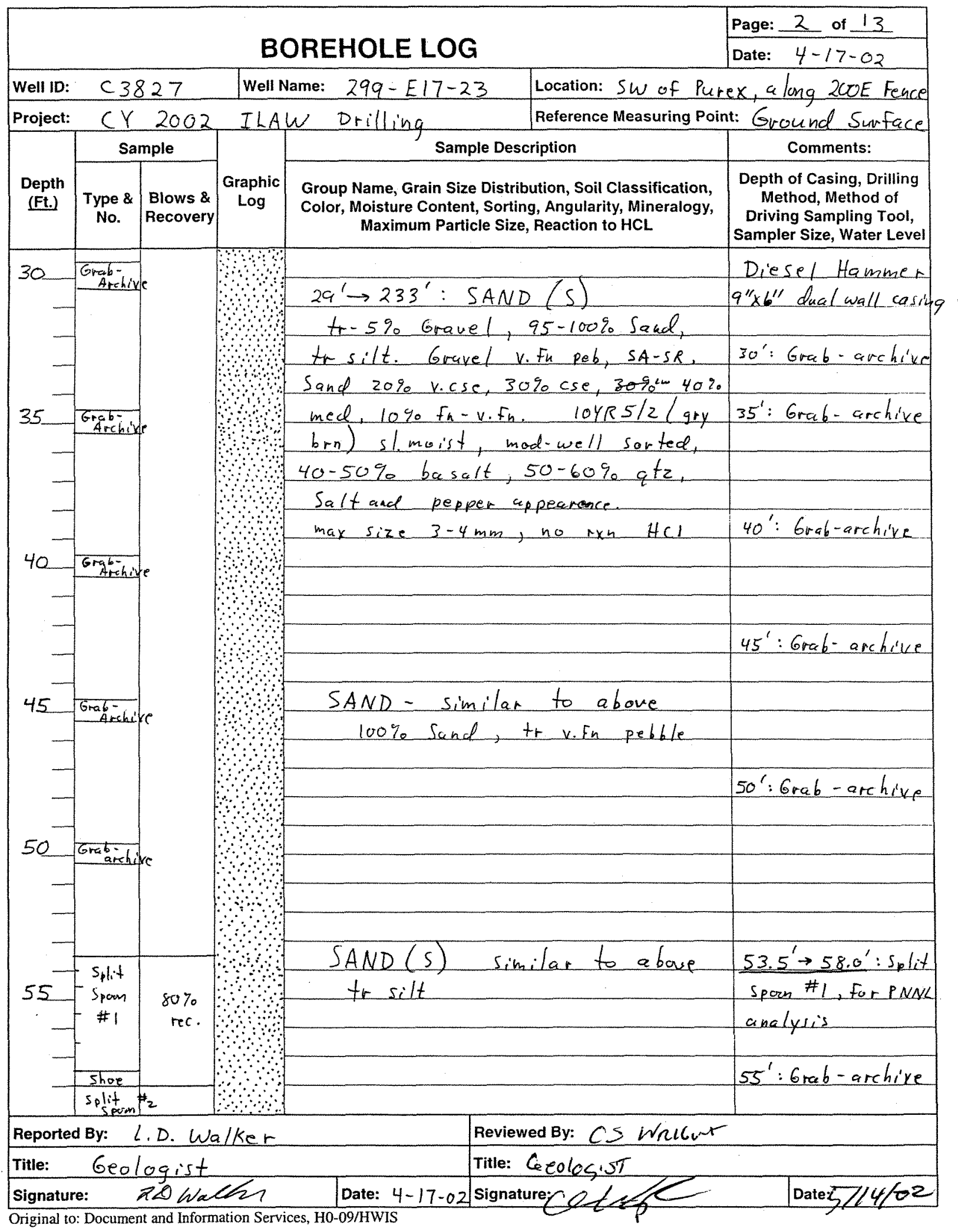

BHI-EE-183 (02-20-2002) 


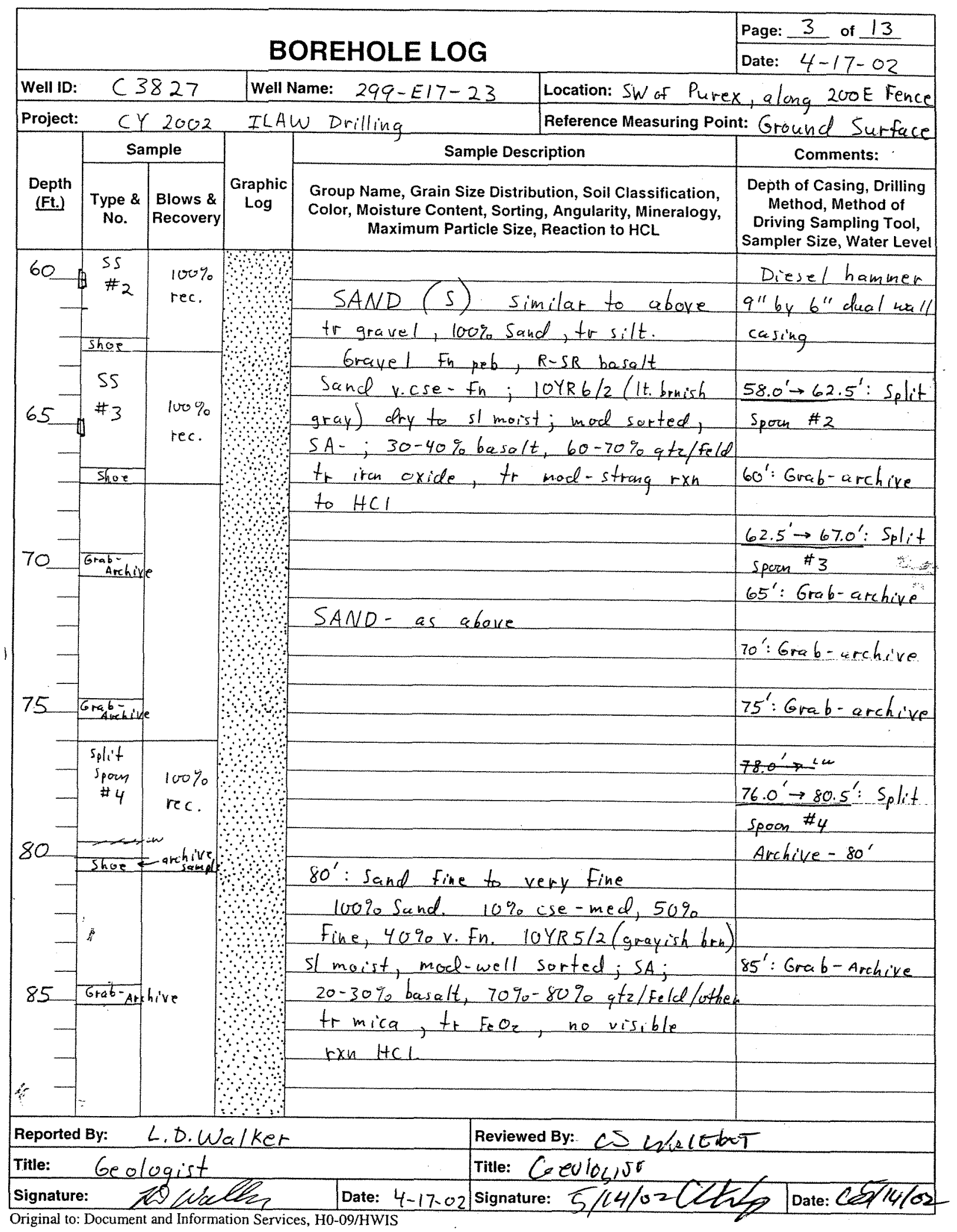

BHI-EE-183 (02-20-2002) 


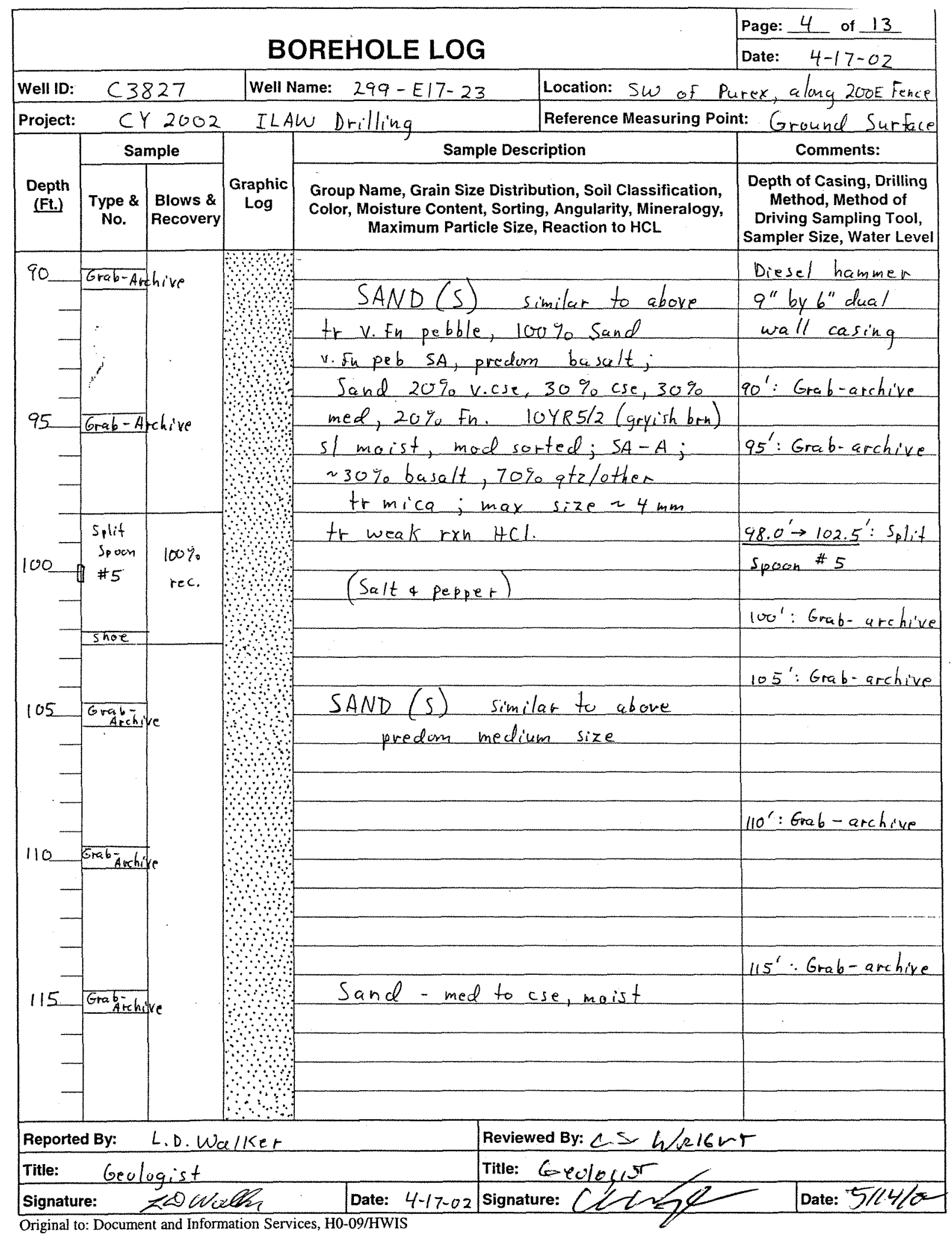

BH1-EE-183 (02-20-2002) 


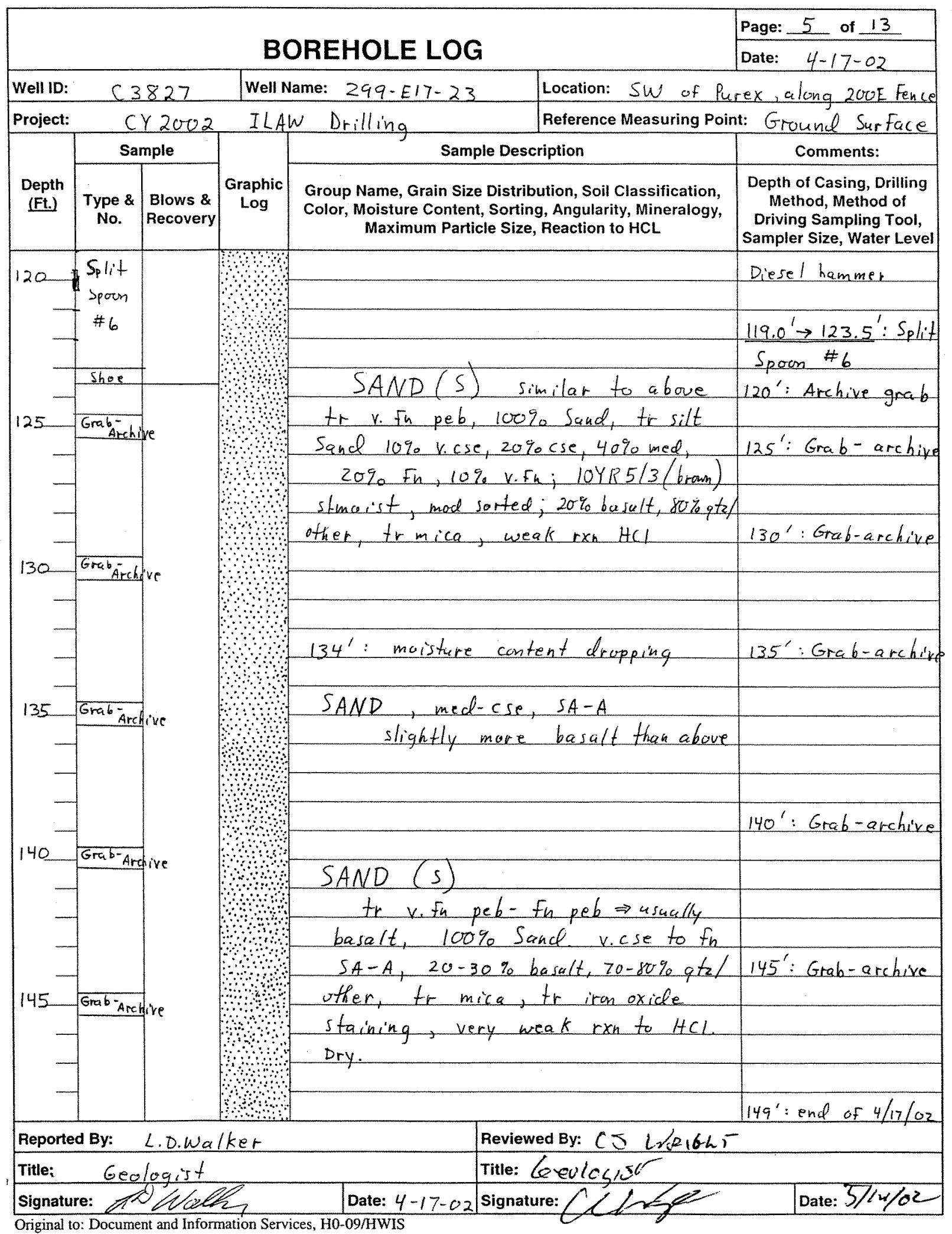

BHI-EE-183 (02-20-2002) 


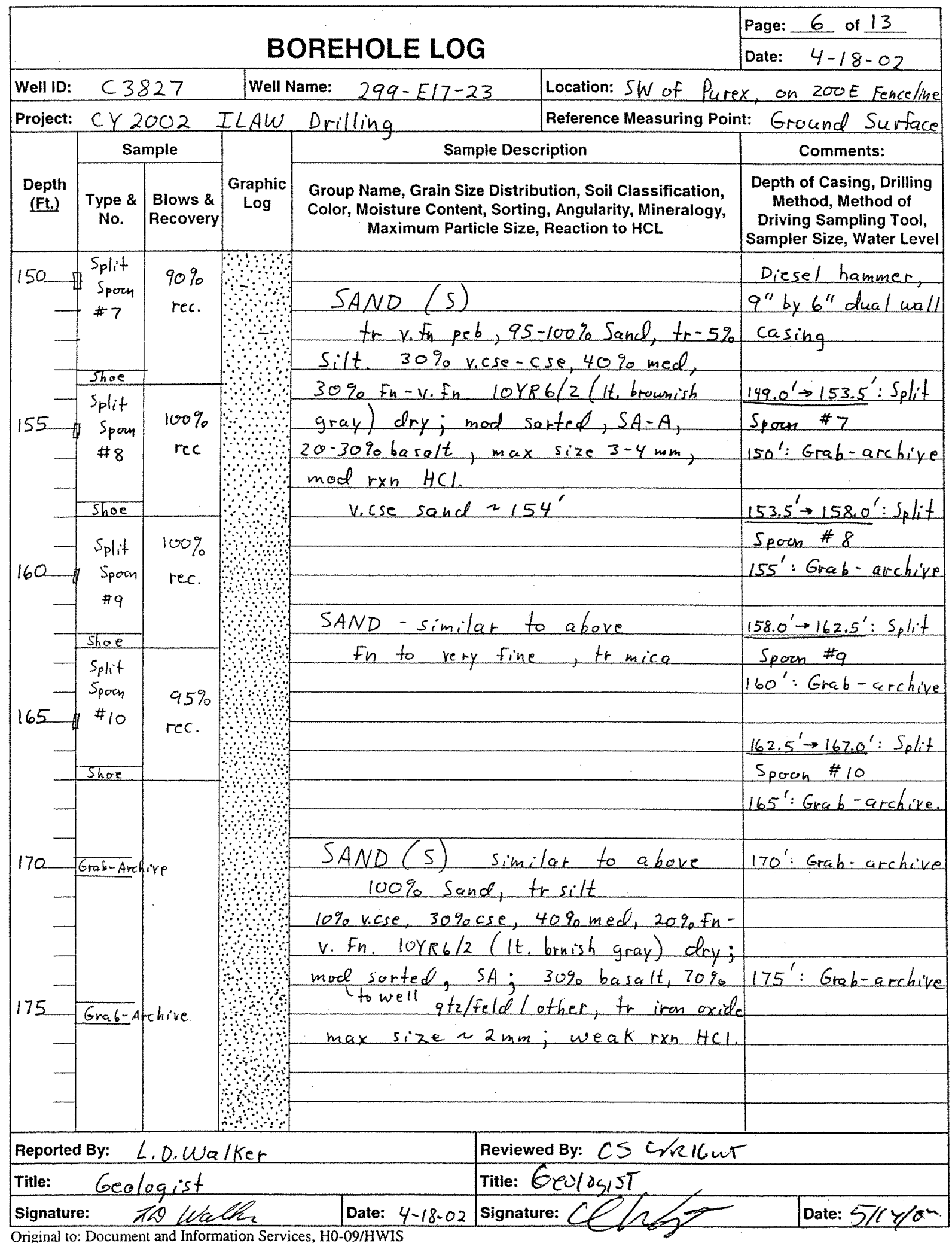

BHI-EE-183 (02-20-2002) 


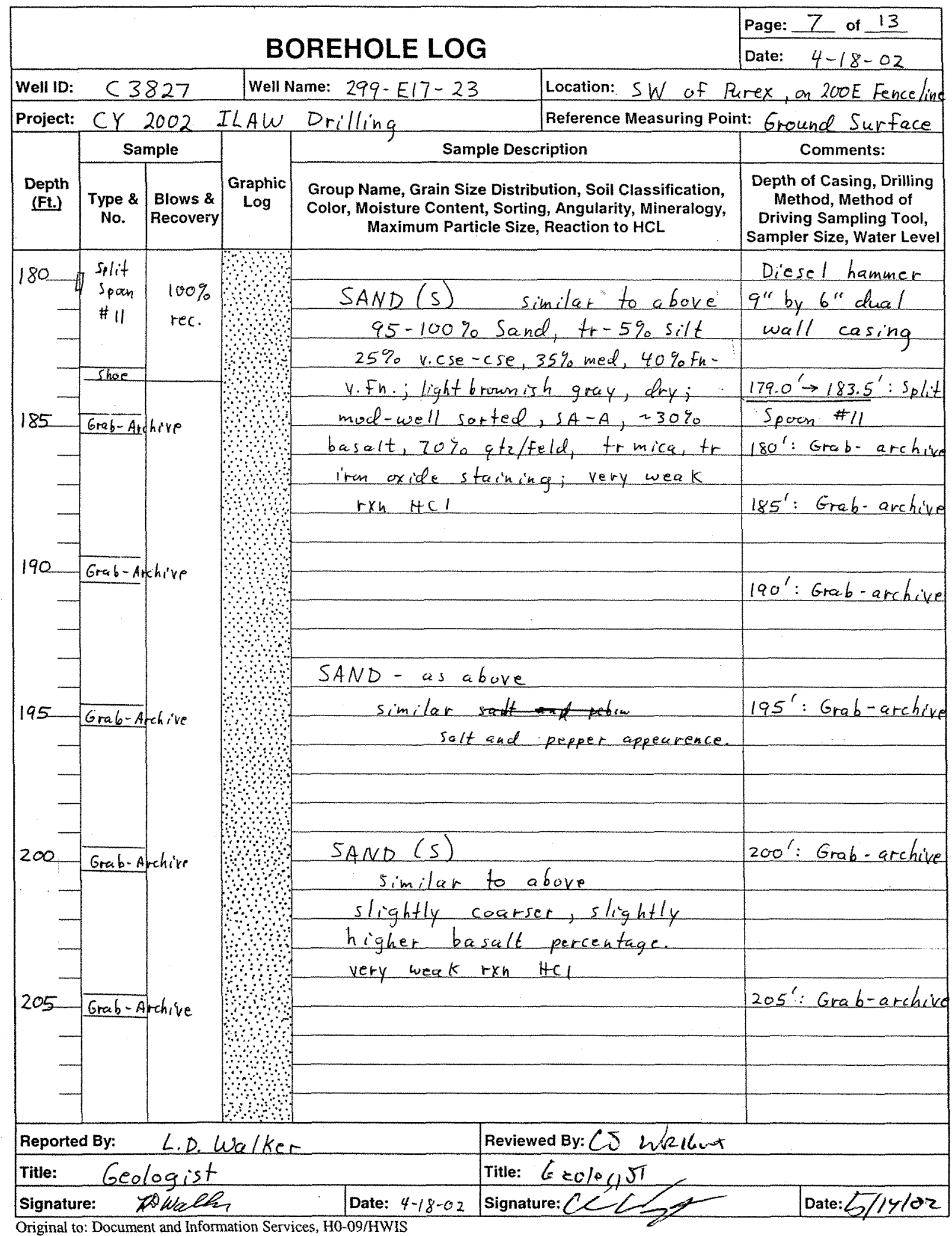

BHI-EE-183 (02-20-2002) 


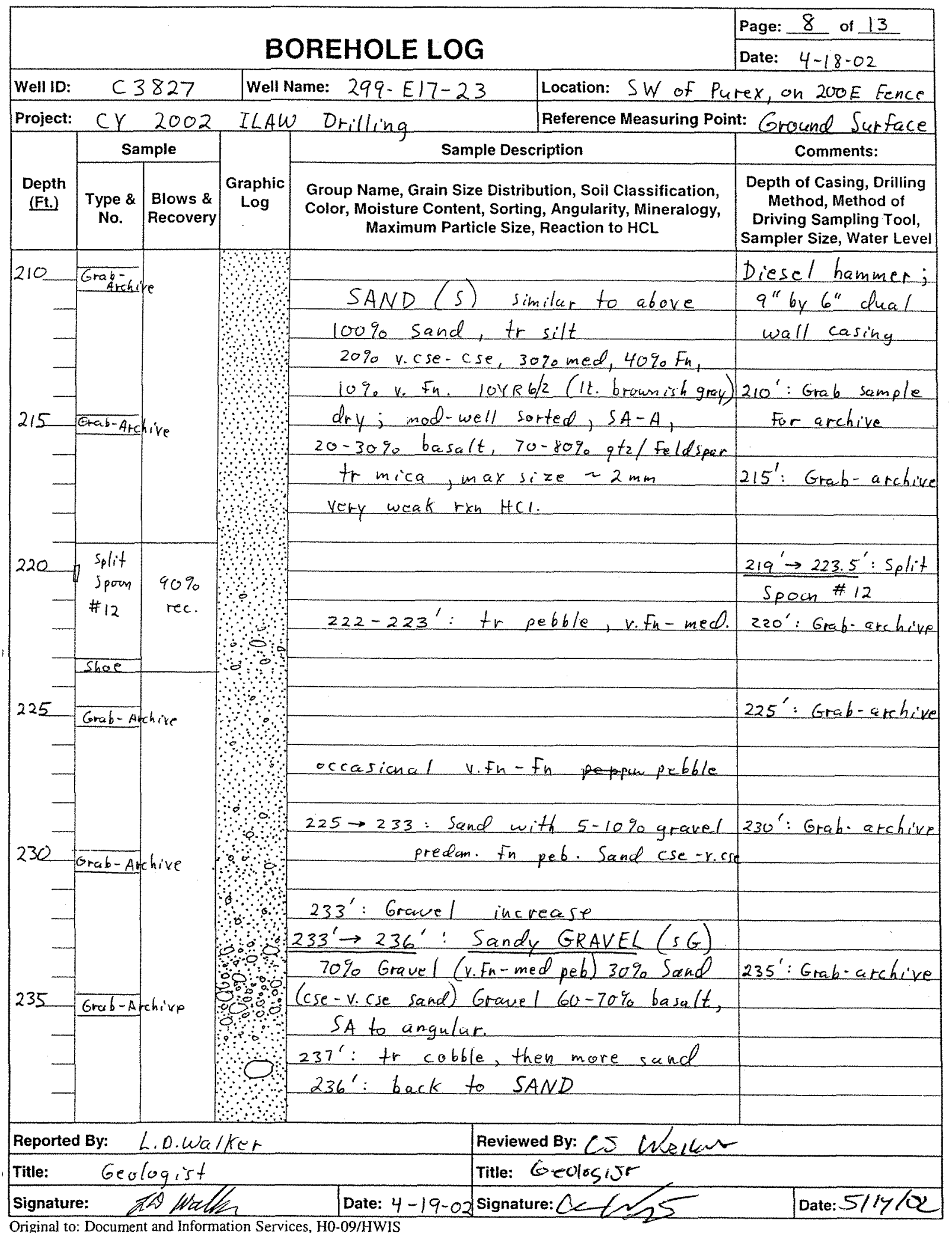

BHI-EE-183 (02-20-2002) 


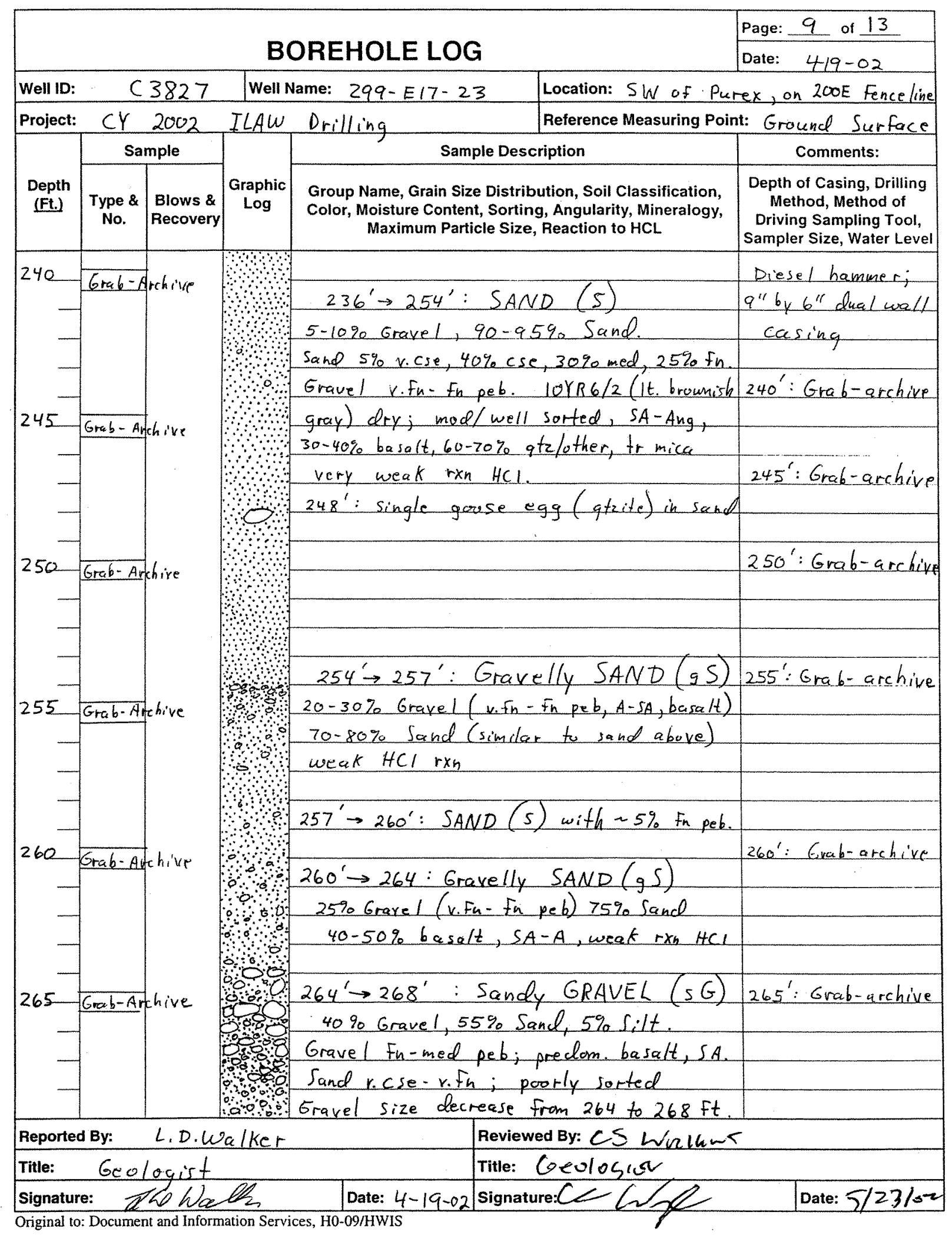

BHI-EE-183 (02-20-2002) 


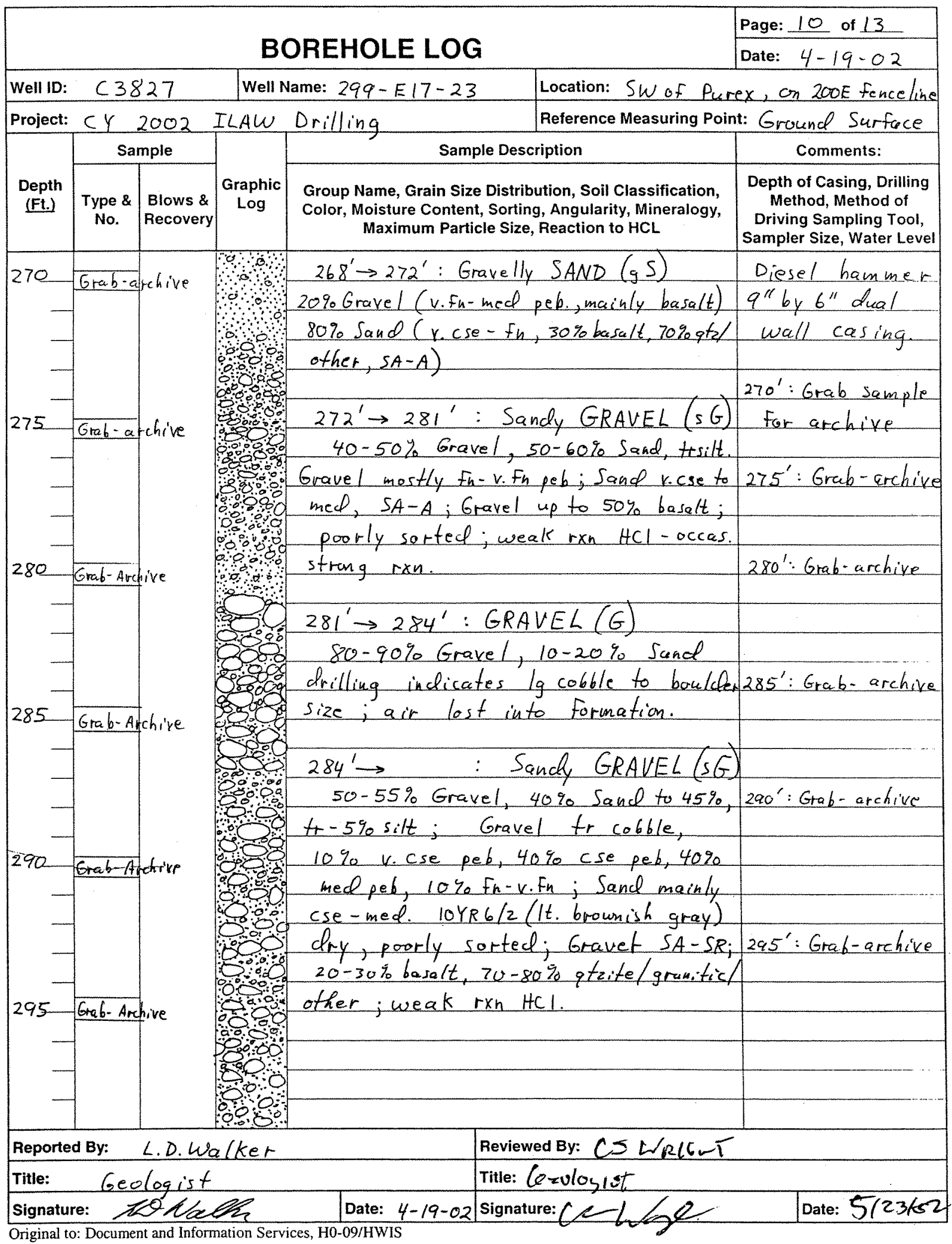

BHI-EE-183 (02-20-2002) 


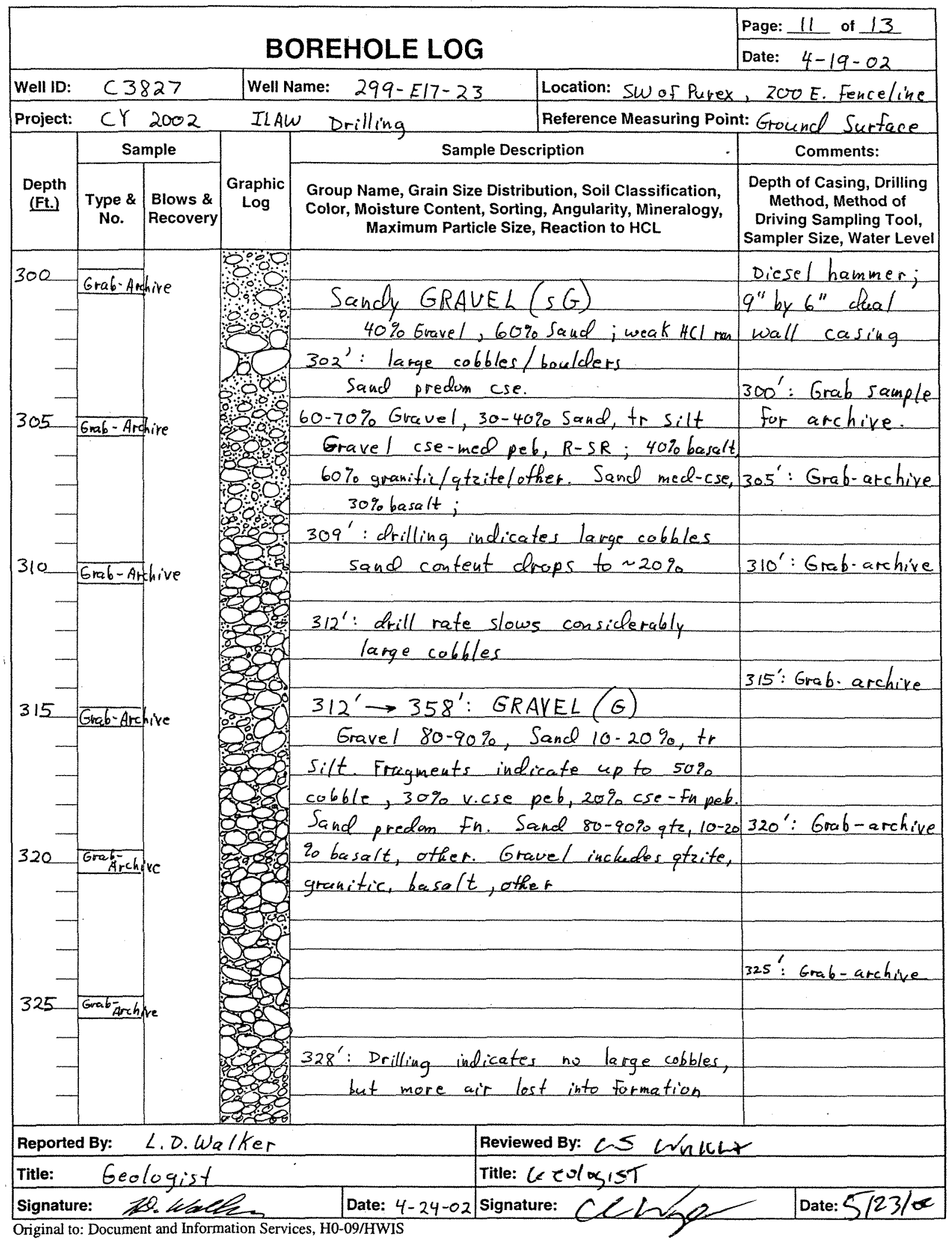

BHI-EE-183 (02-20-2002) 


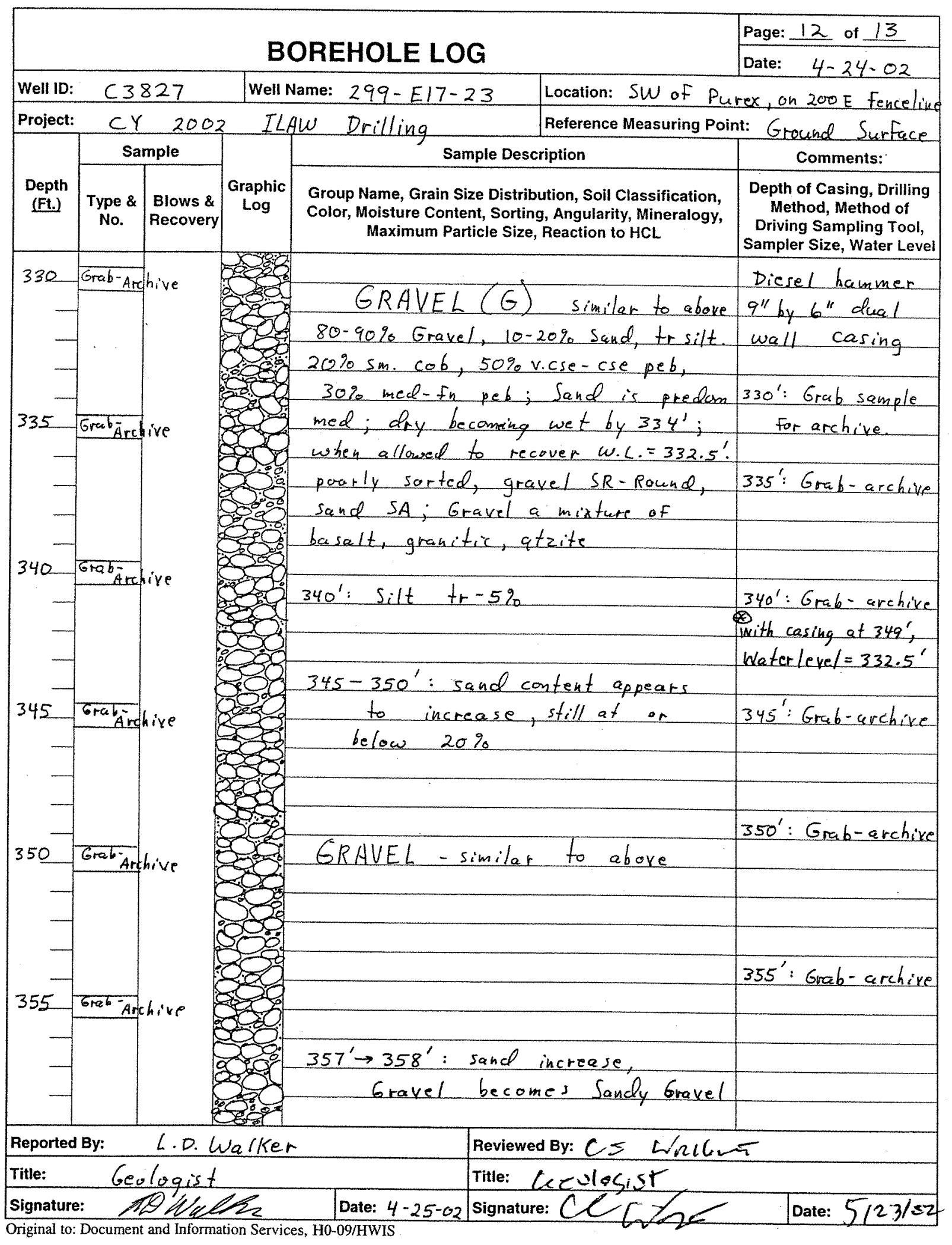

BHI-EE-183 (02-20-2002) 


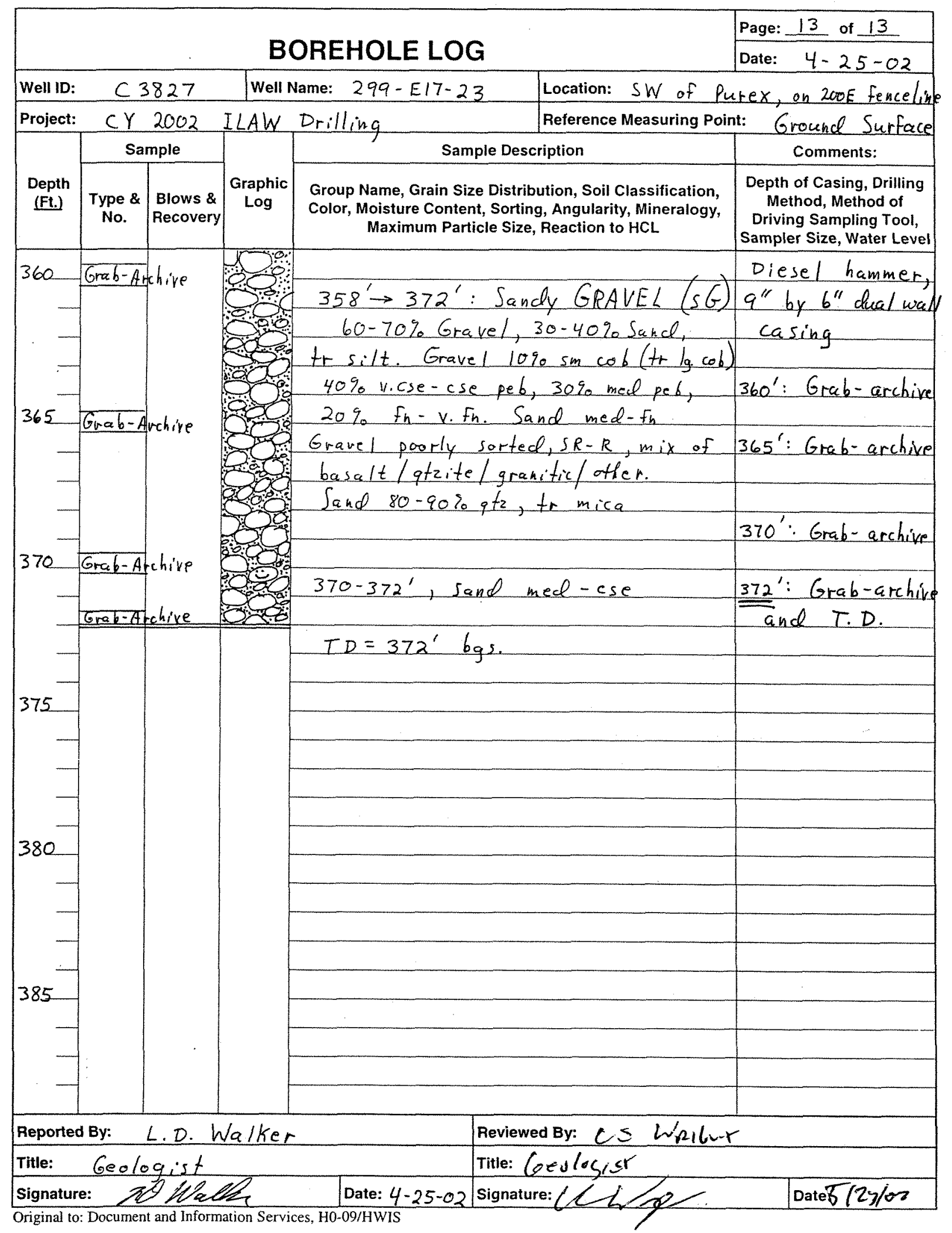

BHI-EE-183 (02-20-2002) 


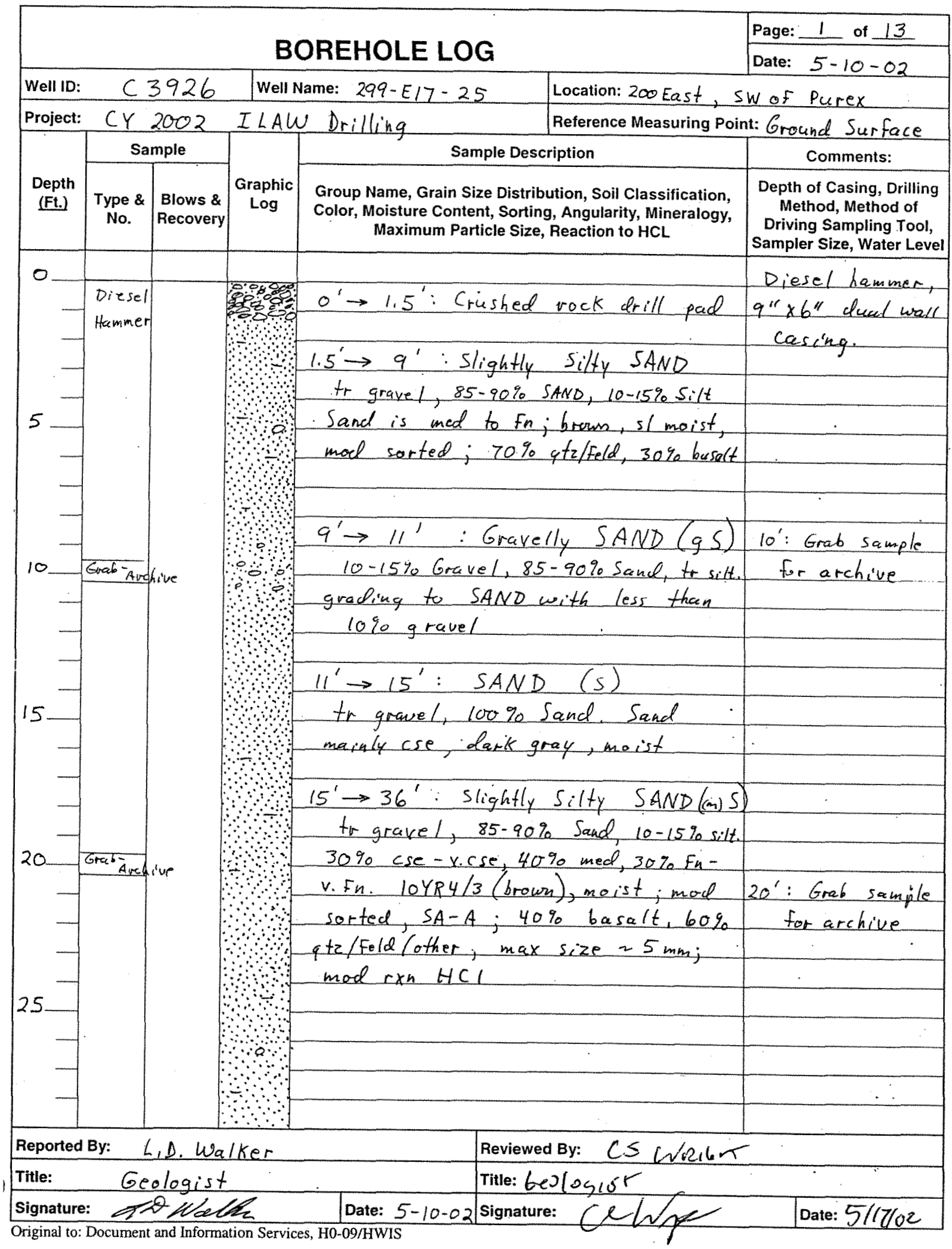

BHI-EE-183 (02-20-2002) 


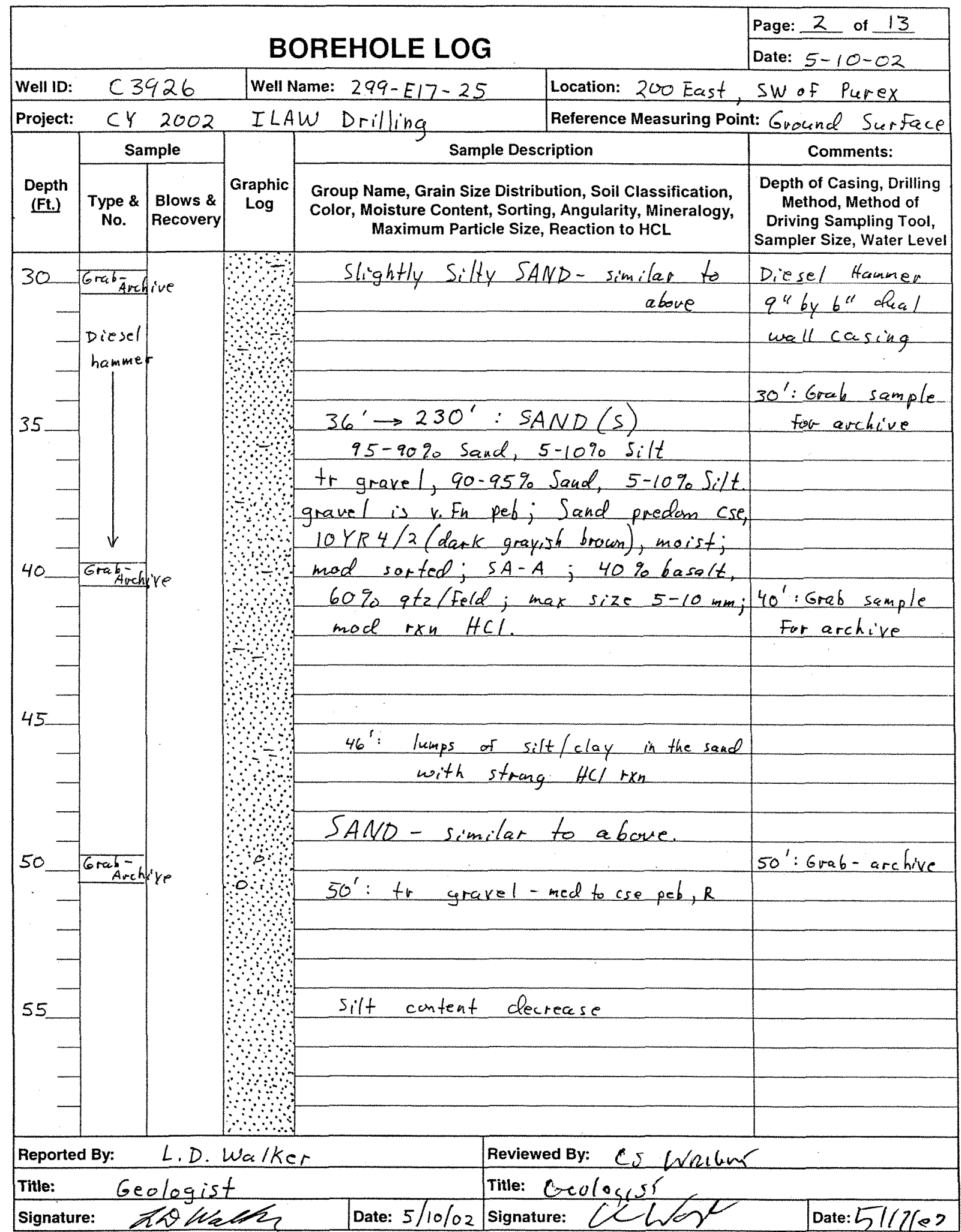

Original to: Document and Information Services, H0-09/HWIS

BHI-EE-183 (02-20-2002) 


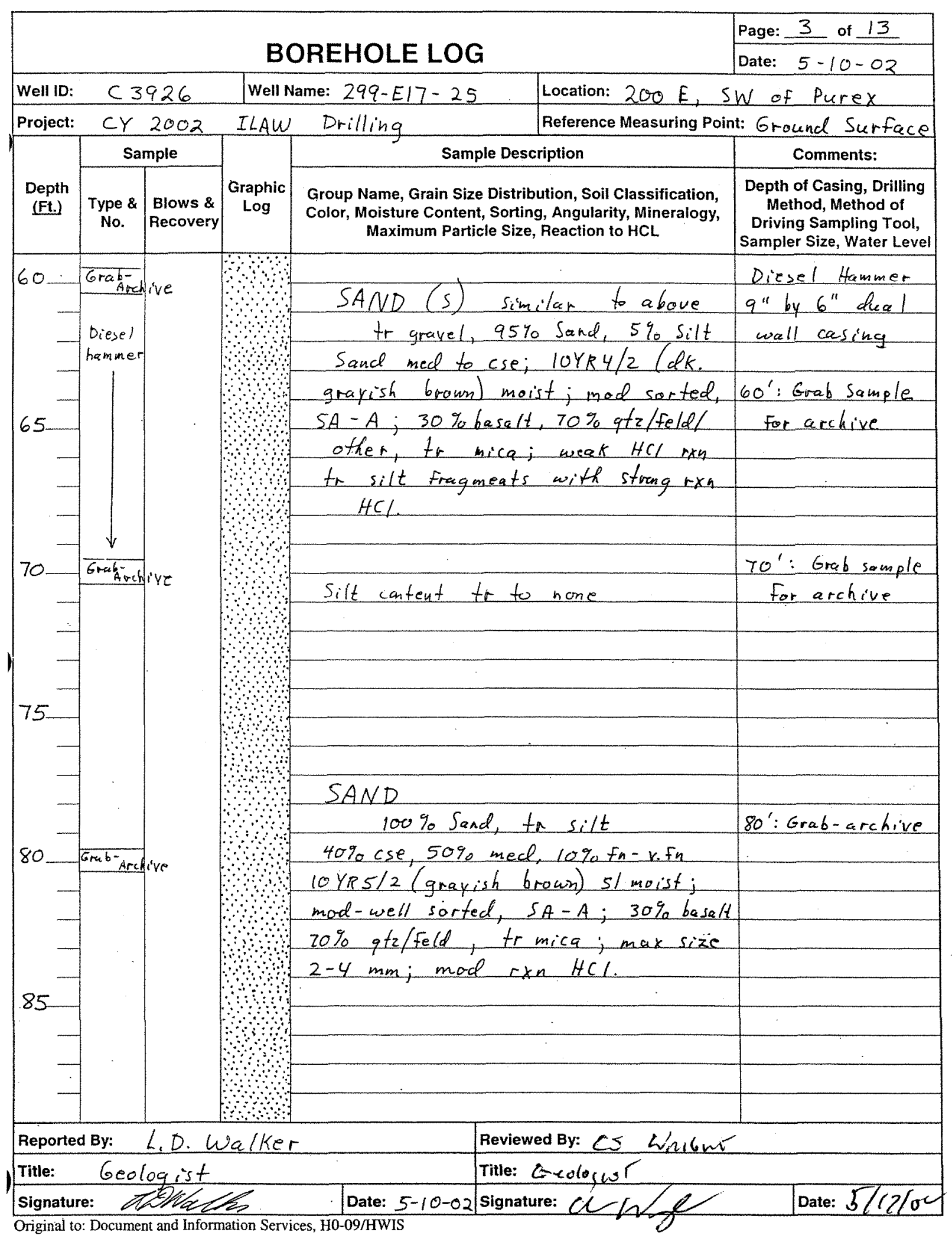

BHI-EE-183 (02-20-2002) 


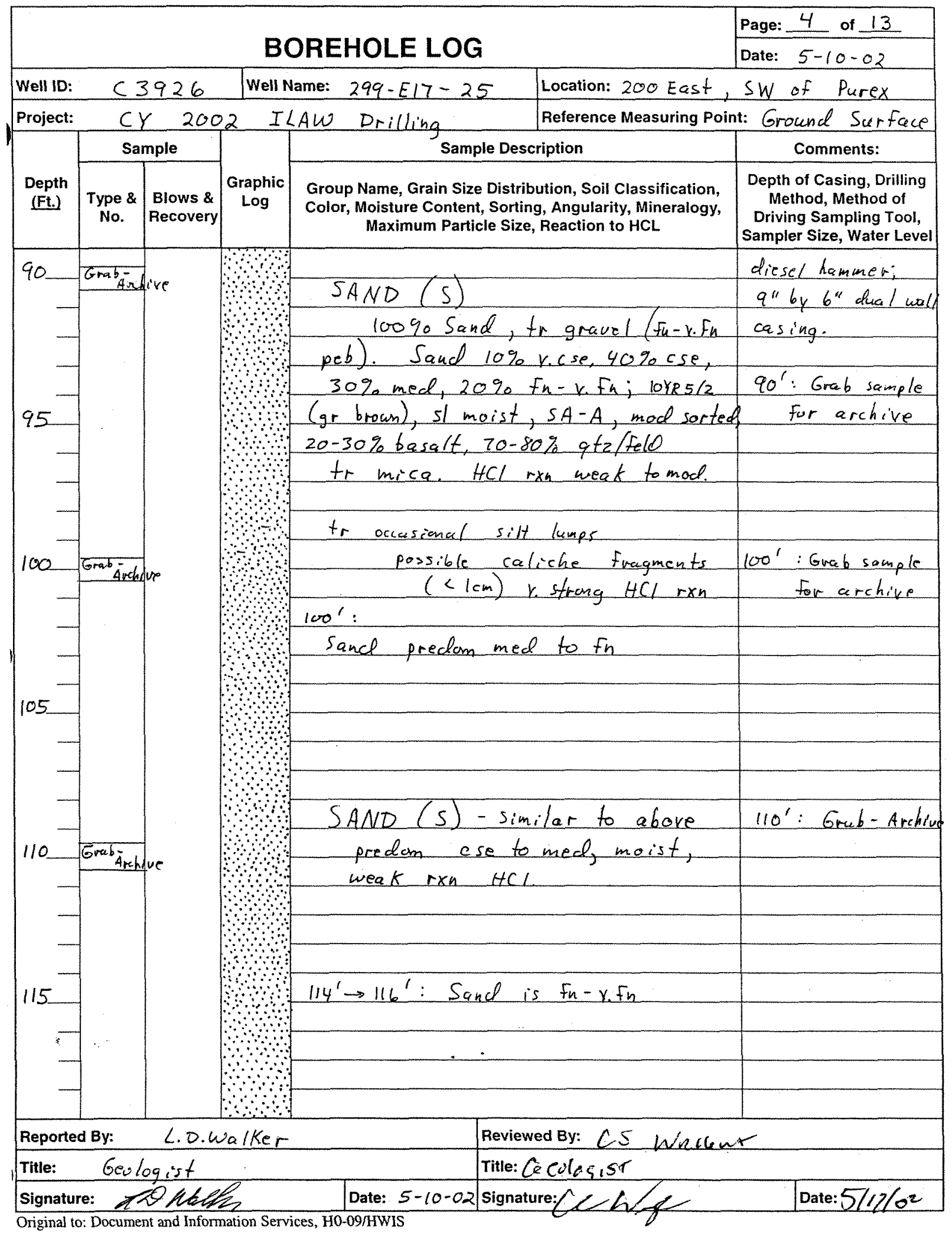

BHI-EE-183 (02-20-2002) 


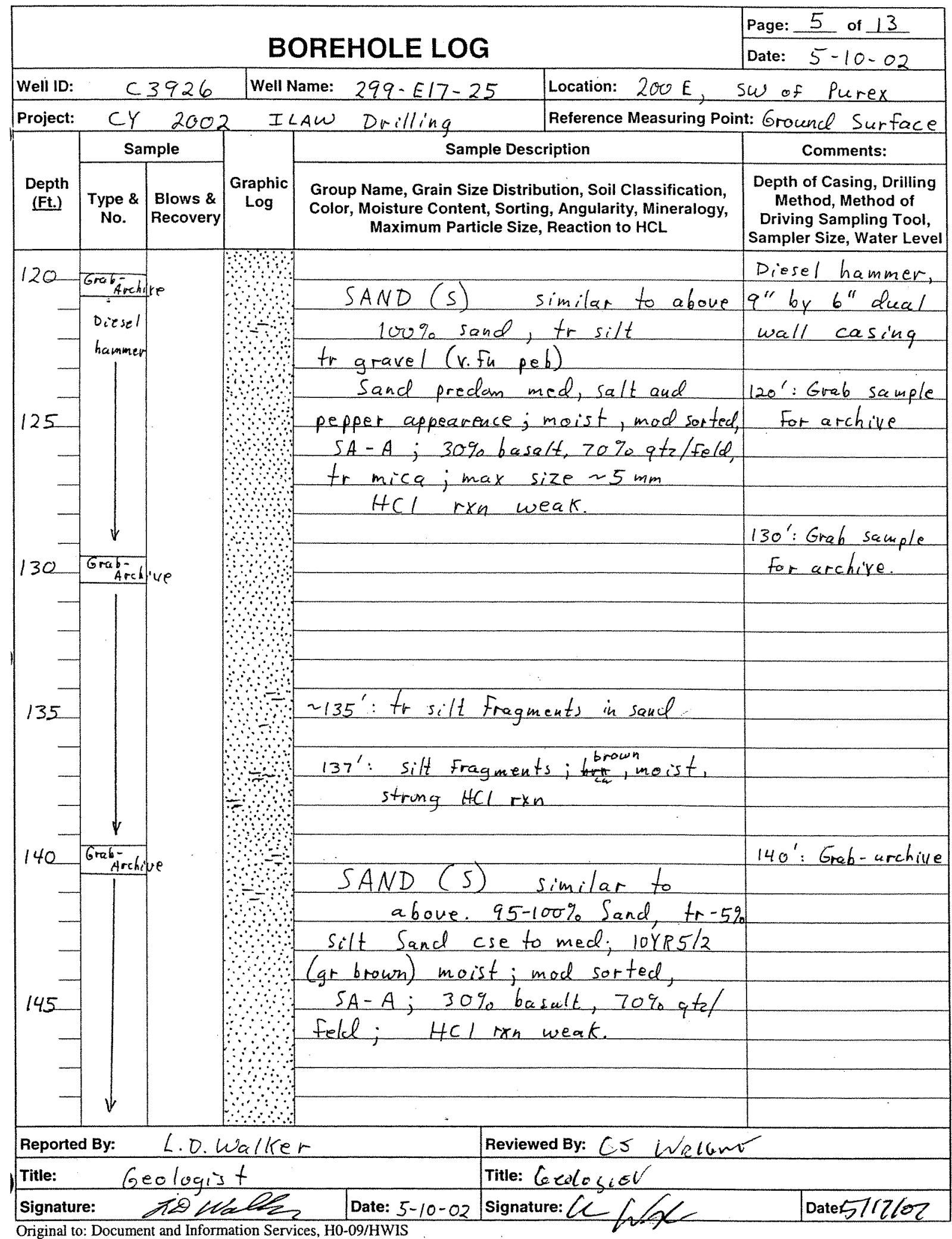

BH-EE-183 (02-20-2002) 


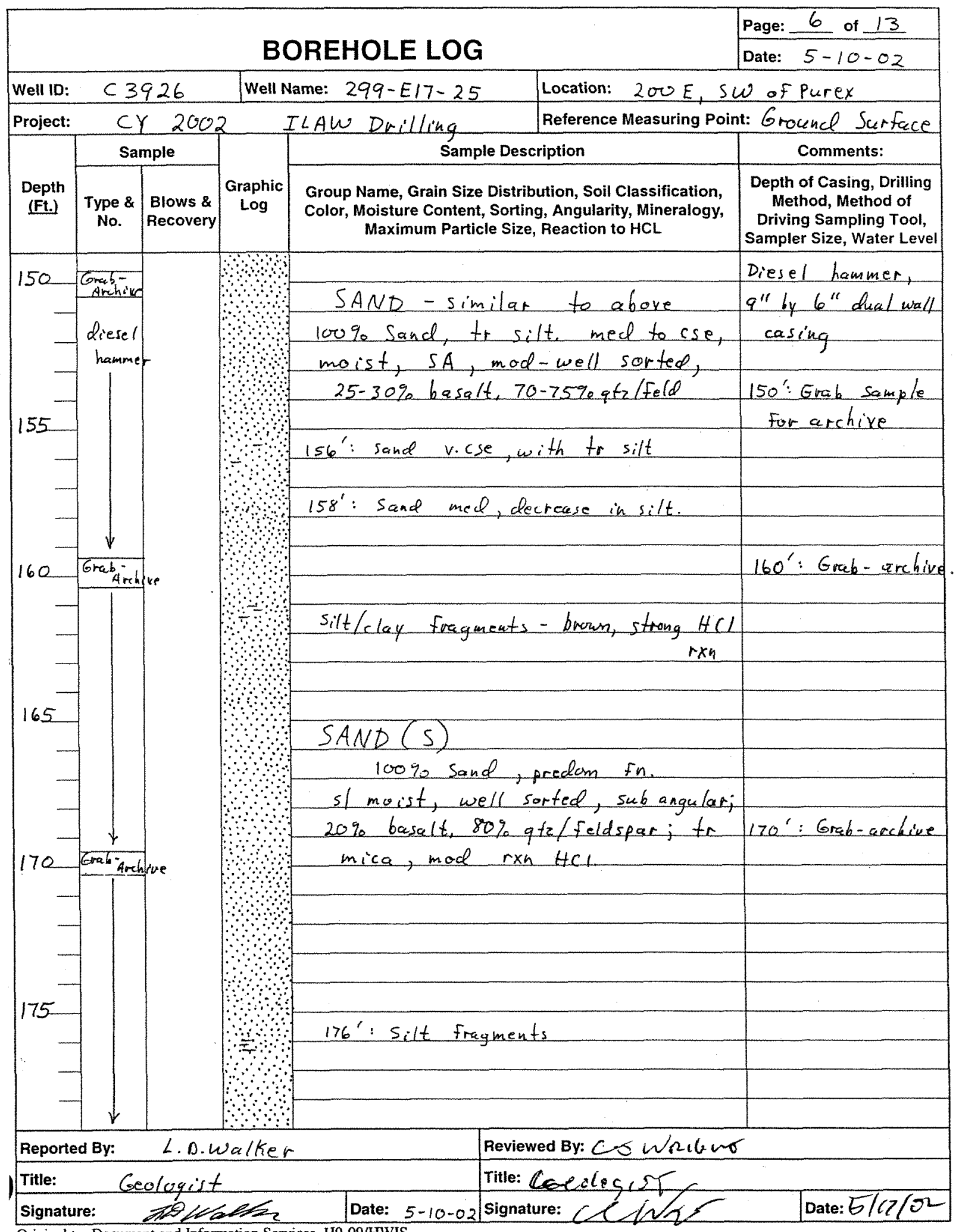

Original to: Document and Information Services, H0-09/HWIS

BHI-EE-183 (02-20-2002) 


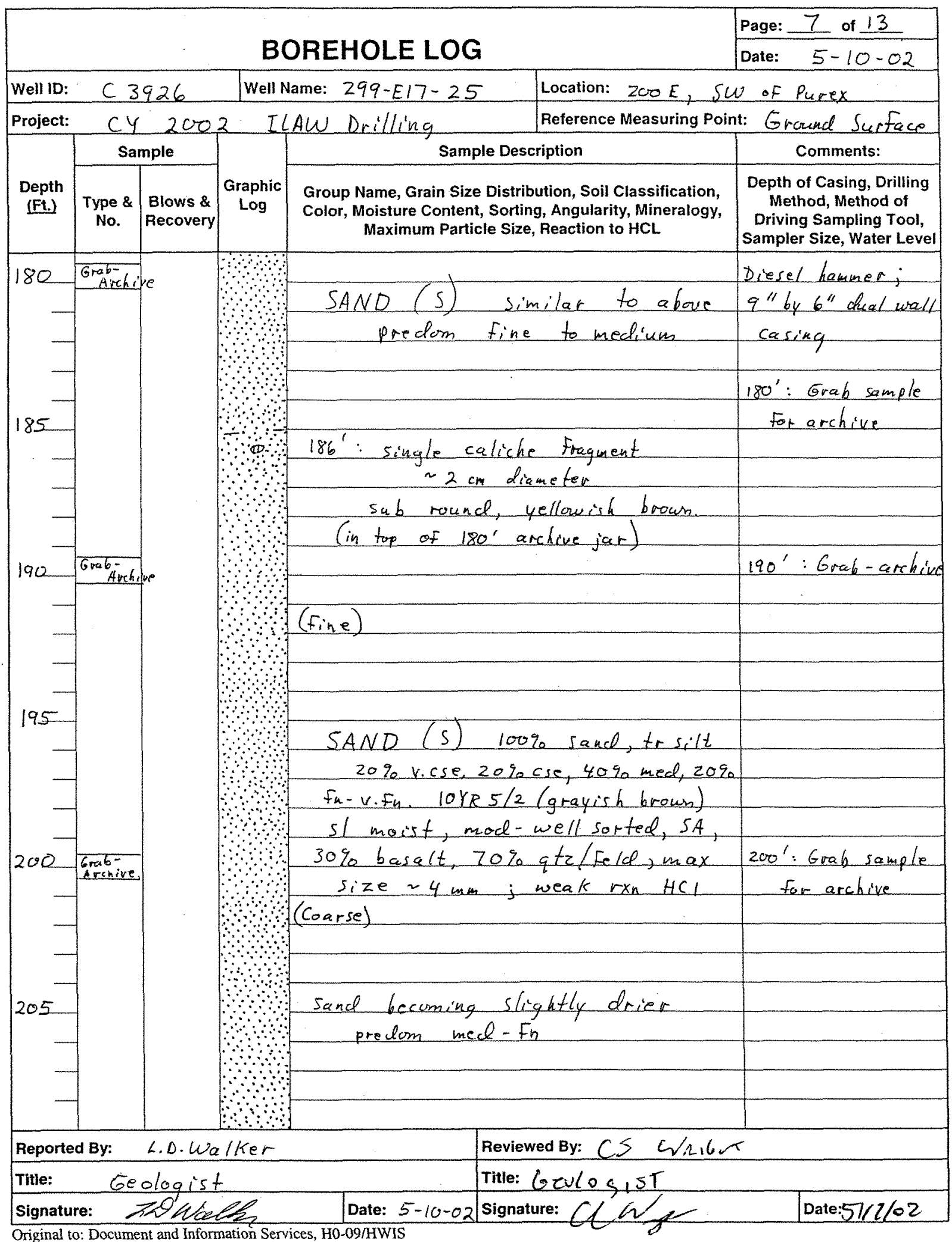

BHI-EE-183 (02-20-2002) 


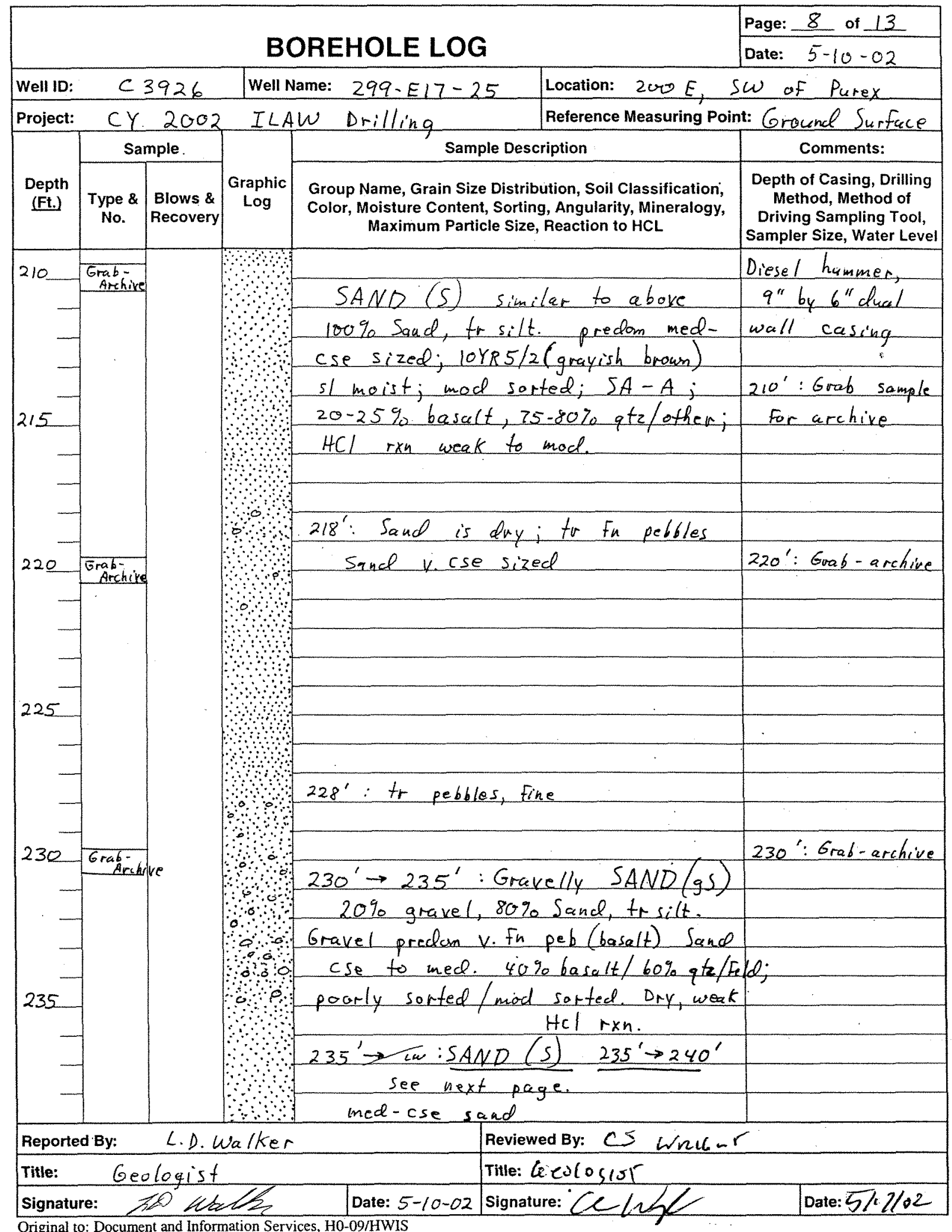

BHI-EE-183 (02-20-2002) 


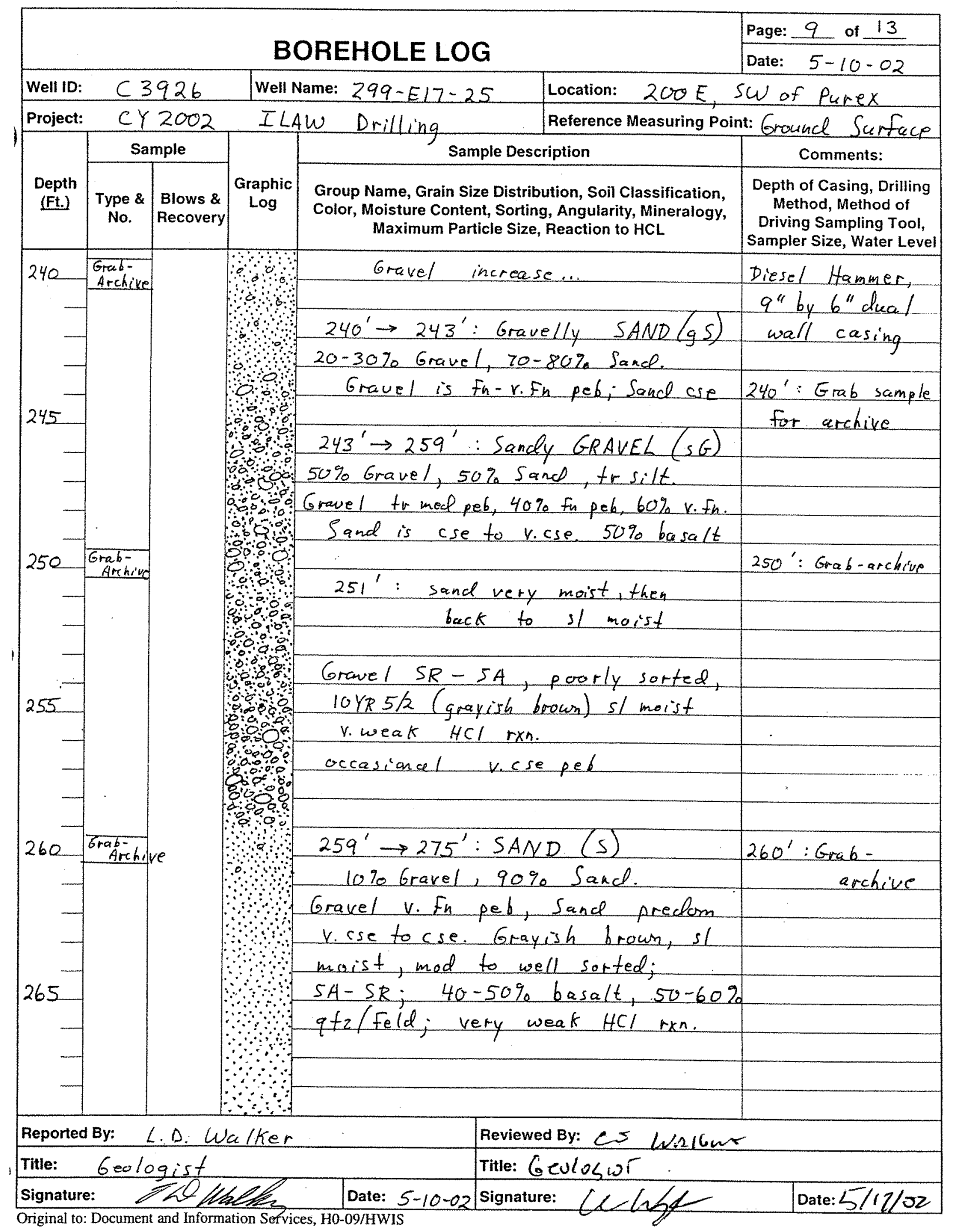

BHI-EE-183 (02-20-2002) 


\begin{tabular}{|c|c|c|c|c|c|c|}
\hline \multirow{2}{*}{\multicolumn{6}{|c|}{ BOREHOLE LOG }} & Page: 10 of 13 \\
\hline & & & & & & Date: $5-10-02$ \\
\hline \multirow{2}{*}{$\begin{array}{l}\text { Well ID: } \\
\text { Project: }\end{array}$} & \multicolumn{2}{|c|}{$C 3926$} & \multicolumn{2}{|c|}{ Well Name: $299-E 17-25$} & \multicolumn{2}{|c|}{ Location: 200 East SW of Purex } \\
\hline & \multicolumn{2}{|c|}{ CY } & 2002 & ILAW Drilling & \multicolumn{2}{|c|}{ Reference Measuring Point: Ground Surface } \\
\hline \multirow[b]{2}{*}{$\begin{array}{l}\text { Depth } \\
\text { (Ft.) }\end{array}$} & \multicolumn{2}{|c|}{ Sample } & \multirow[b]{2}{*}{$\begin{array}{c}\text { Graphic } \\
\text { Log }\end{array}$} & \multirow{2}{*}{\multicolumn{2}{|c|}{ 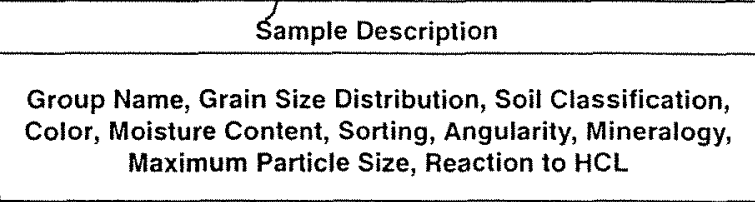 }} & \multirow{2}{*}{\begin{tabular}{|c|} 
Comments: \\
Depth of Casing, Drilling \\
Method, Method of \\
Driving Sampling Tool, \\
Sampler Size, Water Level
\end{tabular}} \\
\hline & $\begin{array}{c}\text { Type \& } \\
\text { No. }\end{array}$ & $\begin{array}{c}\text { Blows \& } \\
\text { Recovery }\end{array}$ & & & & \\
\hline \multirow{5}{*}{270} & \multirow{2}{*}{ Grabs } & & \multirow{5}{*}{ (1) } & \multicolumn{2}{|c|}{ SAND - dry } & \multirow{2}{*}{ Diesel hammer, } \\
\hline & & & & \multicolumn{2}{|c|}{ similat to above. } & \\
\hline & \multirow{3}{*}{ diesel } & & & \multicolumn{2}{|c|}{$100 \% \operatorname{san} d$} & casing. \\
\hline & & & & & & \\
\hline & & & & & & 270': Grab Sample \\
\hline 275 & & & & $275^{\prime} \rightarrow 382.5^{\prime}$ & : Sandy GRAVEL & For archive \\
\hline & & & & $(5 G) 60-$ & $-70 \%$ Gravel; $30-35 \%$ & \\
\hline & & & 0800 & Sand, tr-59 & Qo silt & \\
\hline & & & & Gravel sm.c & $\operatorname{cob}$ to Fn pob, sance & \\
\hline & & & & predom Fine, & to $v$. Fine. & \\
\hline 280 & Grabichio & & & Gravel SR- & SA; $30 \%$ basalt, & $280^{\prime}:$ Grab-archive \\
\hline & & & 80 & $70 \%$ atzite $/ g$ & granitic/other & \\
\hline & & & & Dry; no rx & $x_{n} \mathrm{HCl}$ & \\
\hline & & & & & & \\
\hline 285 & & & & $285^{\circ}$ : baselt $c$ & cobbles (fragments) & \\
\hline & & & & dry, silt con & intent $=5 \%$ & \\
\hline & & & & & & \\
\hline & v & & & & & 290': Grab-archive \\
\hline 290 & $\frac{1}{G+a b-G a t}$ & & & & & \\
\hline & & & & & & \\
\hline & & & & Sandy GRA & AVEb - as above & \\
\hline & & & & $75 \%$ gra & avel, 2090 Sand, $5 \%$ & \\
\hline & & & & Silt & & \\
\hline 295 & & & & & & \\
\hline & & & & & & \\
\hline & & & & & & \\
\hline & $\psi$ & & 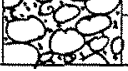 & & & \\
\hline Reporte & d By: & L.D. Wo & alker & & Reviewed By: CS Winlu & \\
\hline Title: & .600 & $\log _{15} f$ & & & Title: ceolorcst & \\
\hline Signatur & & L Mat & & Date: $5-10-02 \mathrm{~s}$ & signature: $\mathbb{C}-6$ & Date: $5 / 1 / 102$ \\
\hline
\end{tabular}

BHI-EE-183 (02-20-2002) 


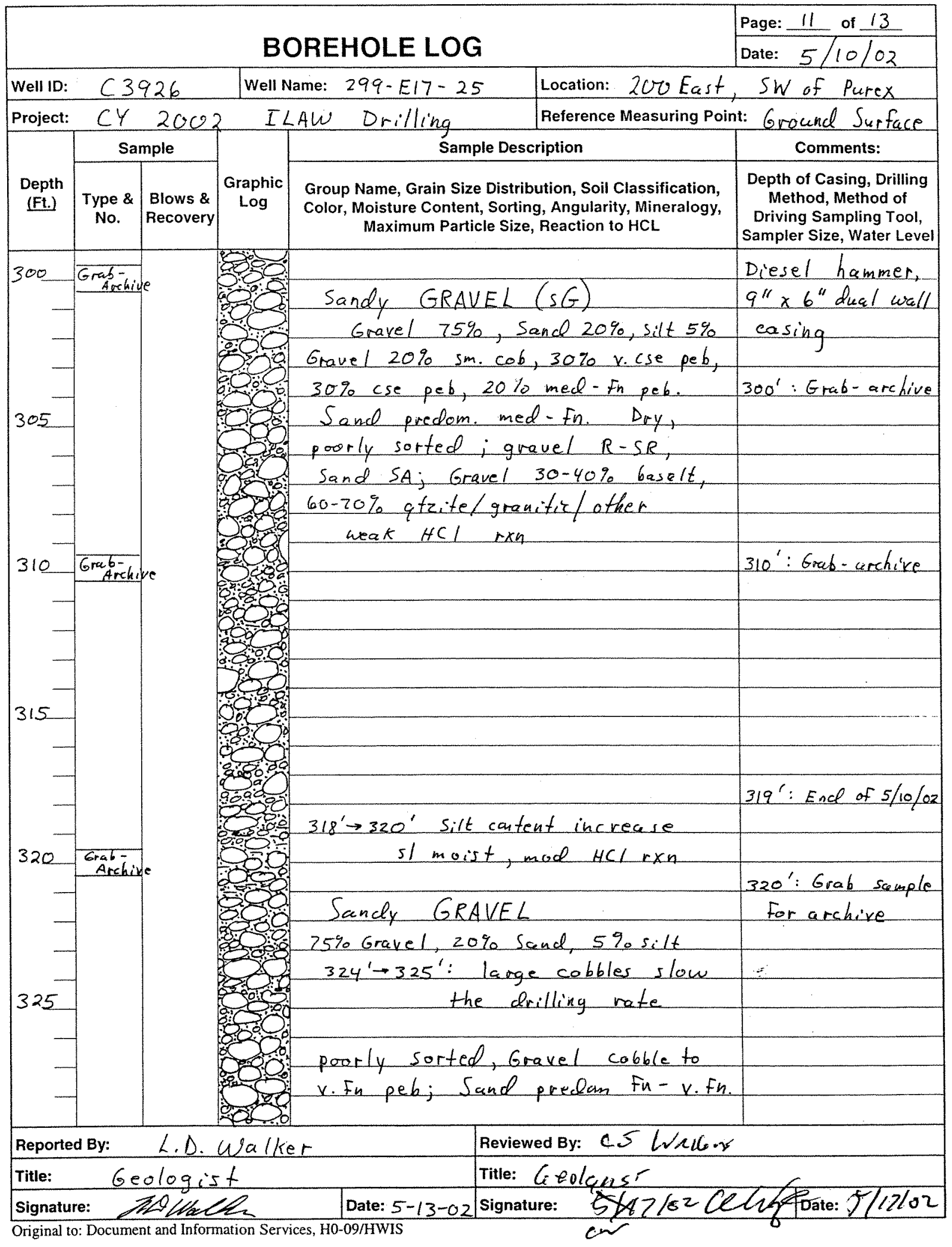

BHI-EE-183 (02-20-2002) 


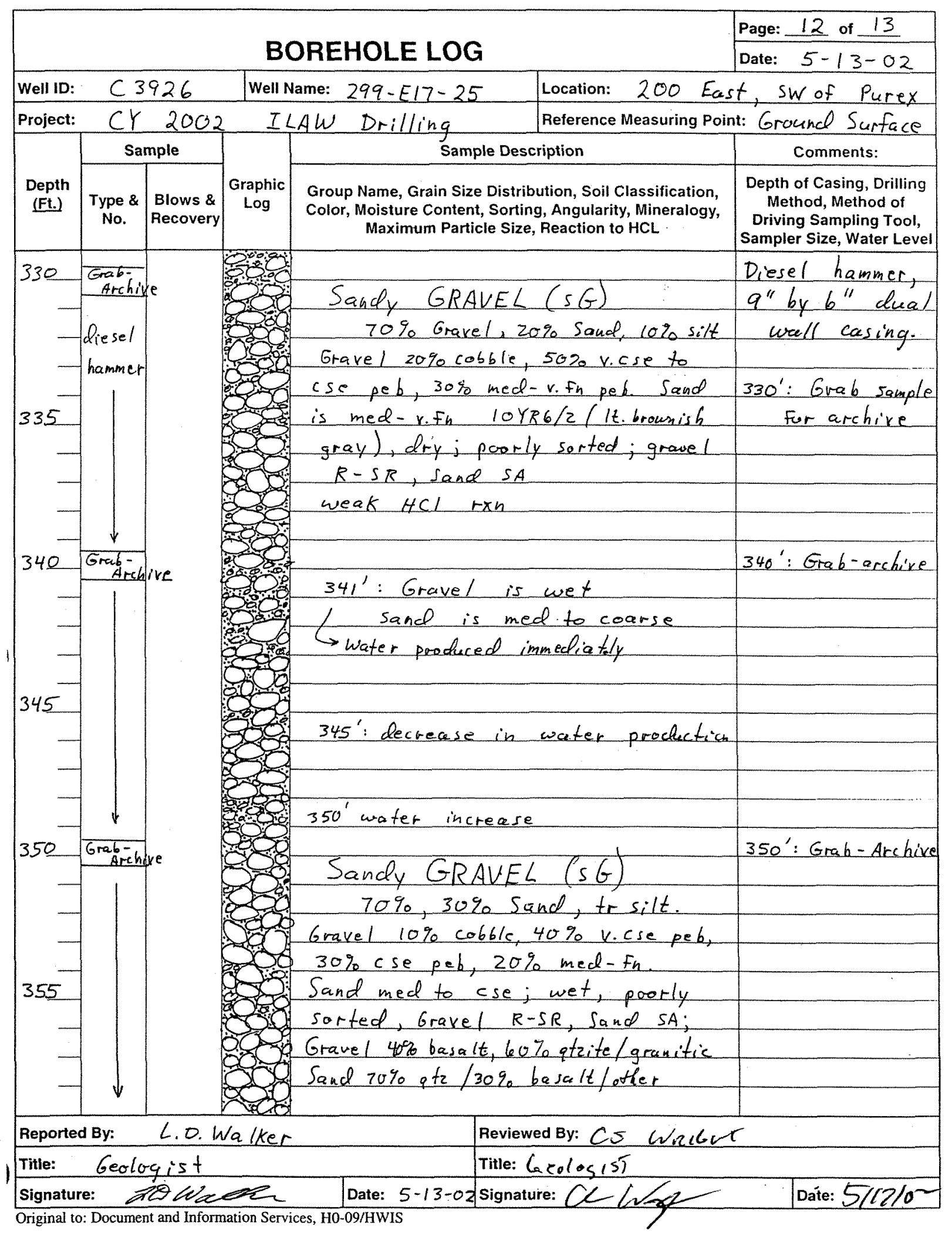

BHI-EE-183 (02-20-2002) 


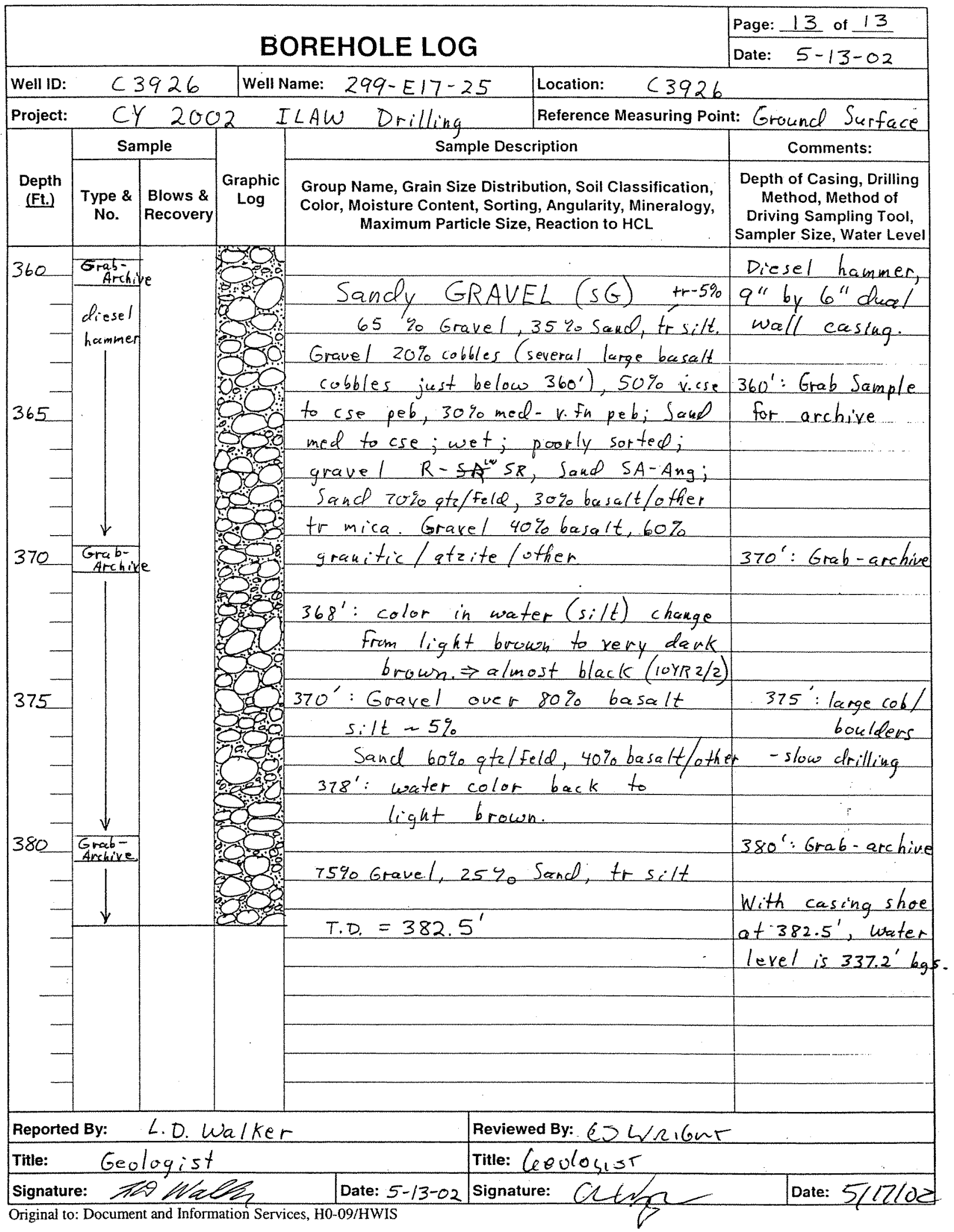

BHI-EE-183 (02-20-2002) 


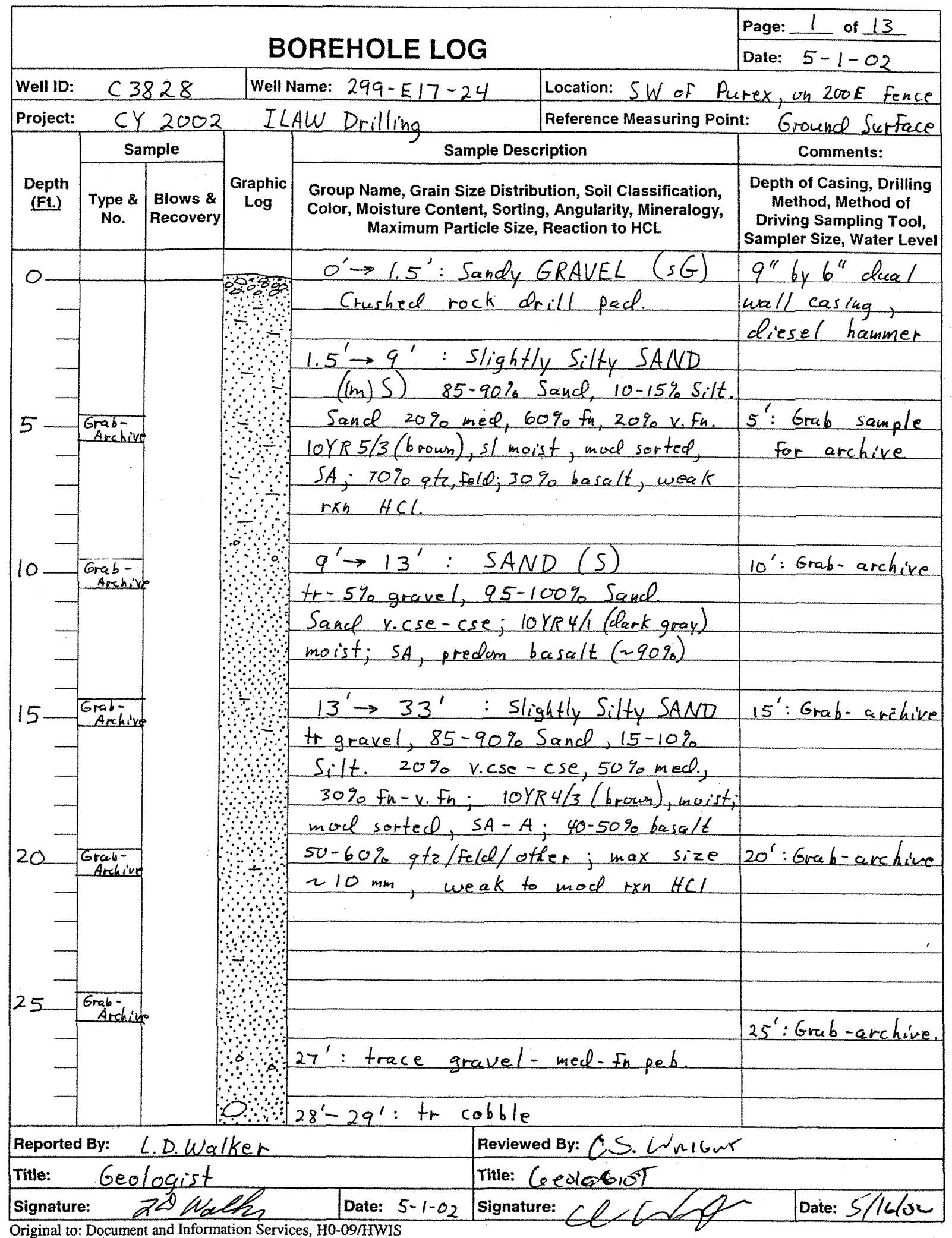

BHI-EE-183 (02-20-2002) 


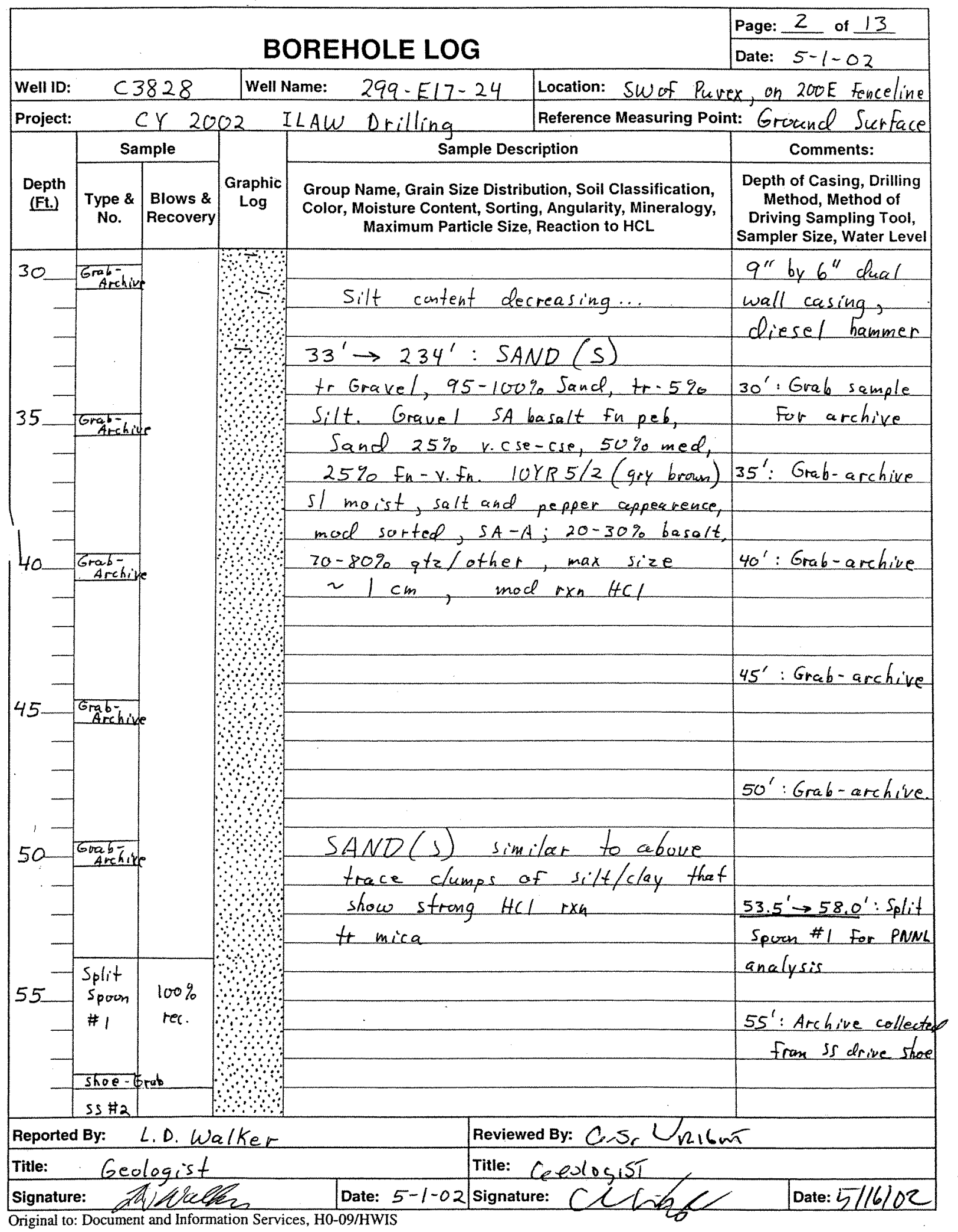

BHI-EE-183 (02-20-2002) 


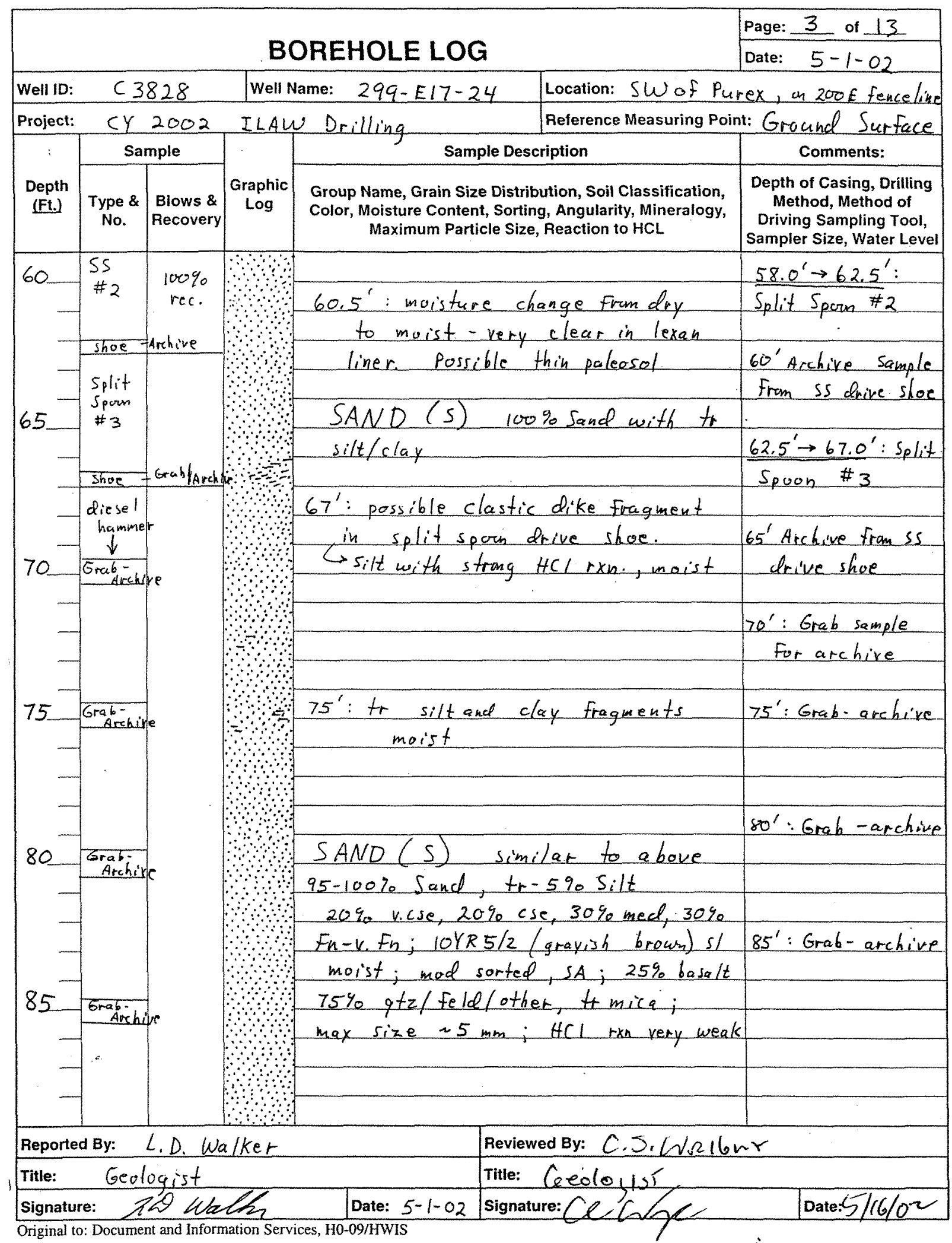

BHI-EE-183 (02-20-2002) 


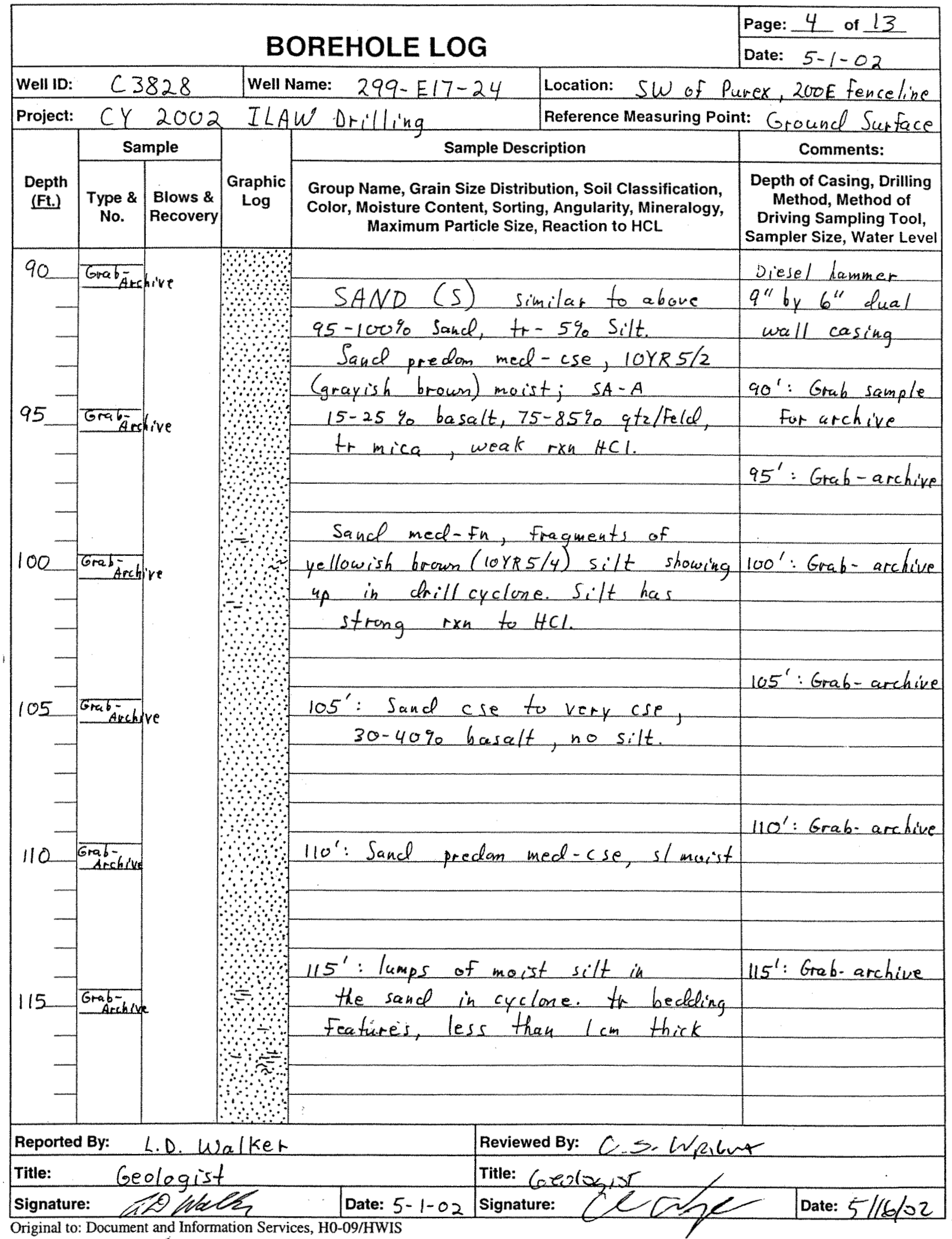

BHI-EE-183 (02-20-2002) 


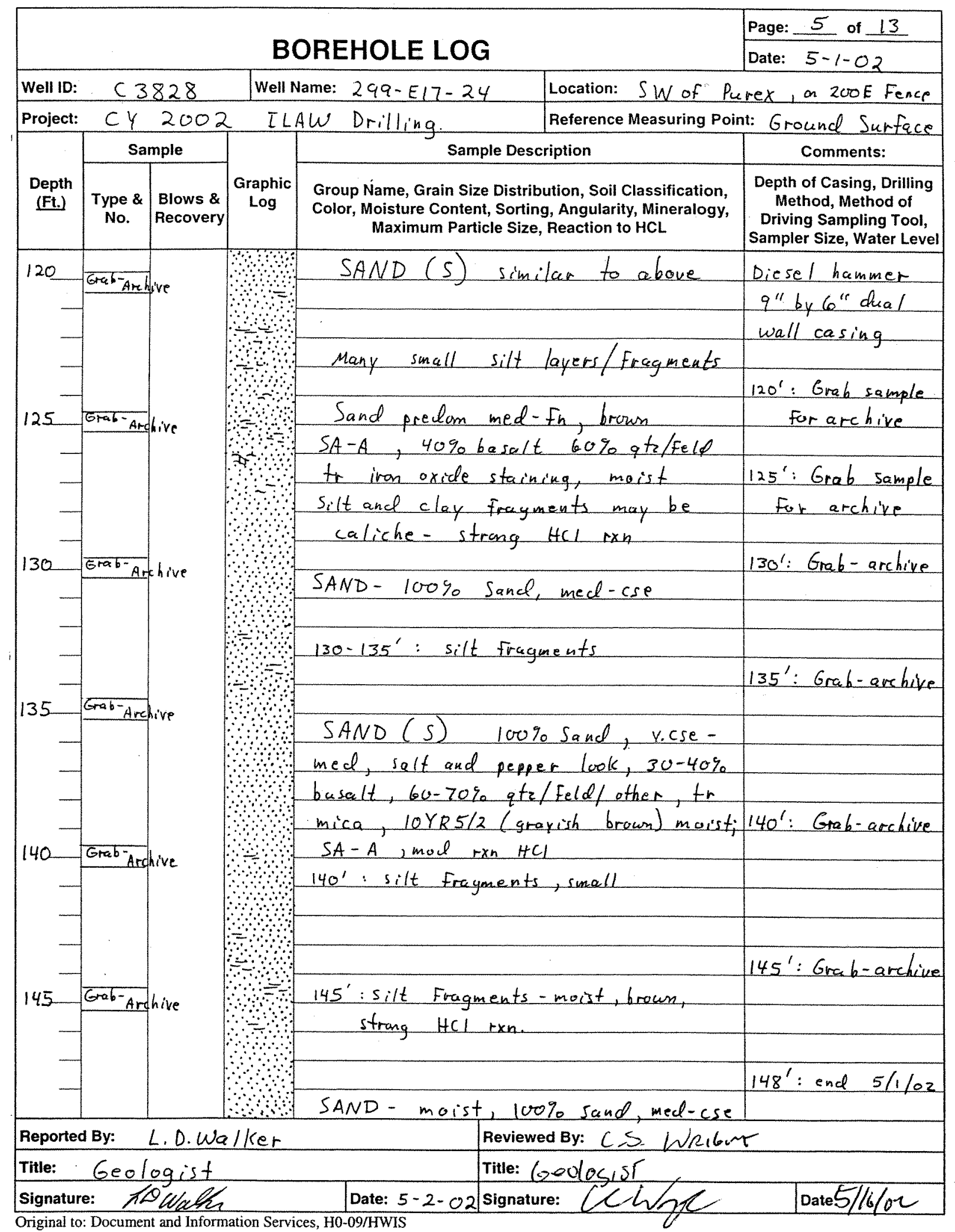

BHI-EE-183 (02-20-2002) 


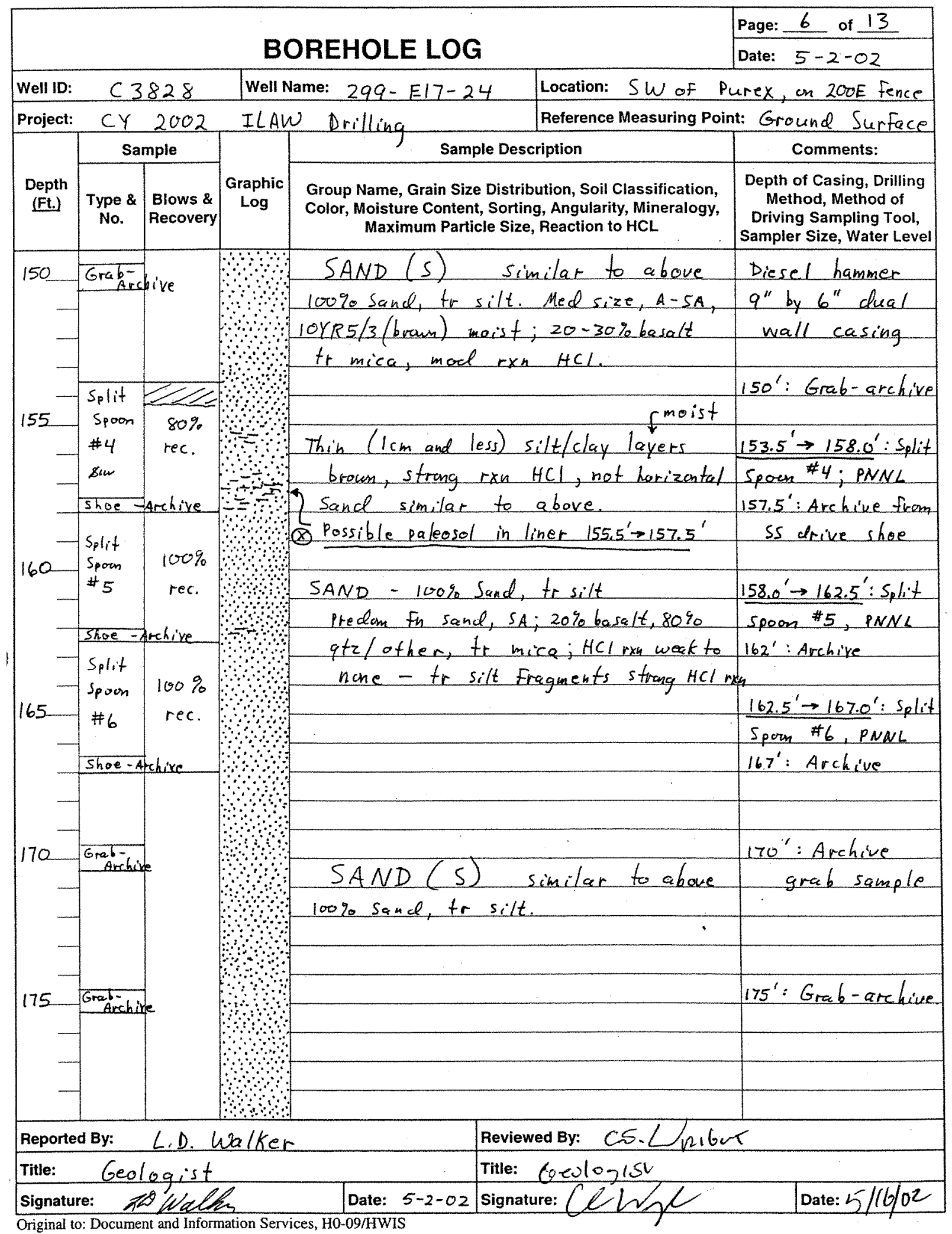

BHI-EE-183 (02-20-2002) 


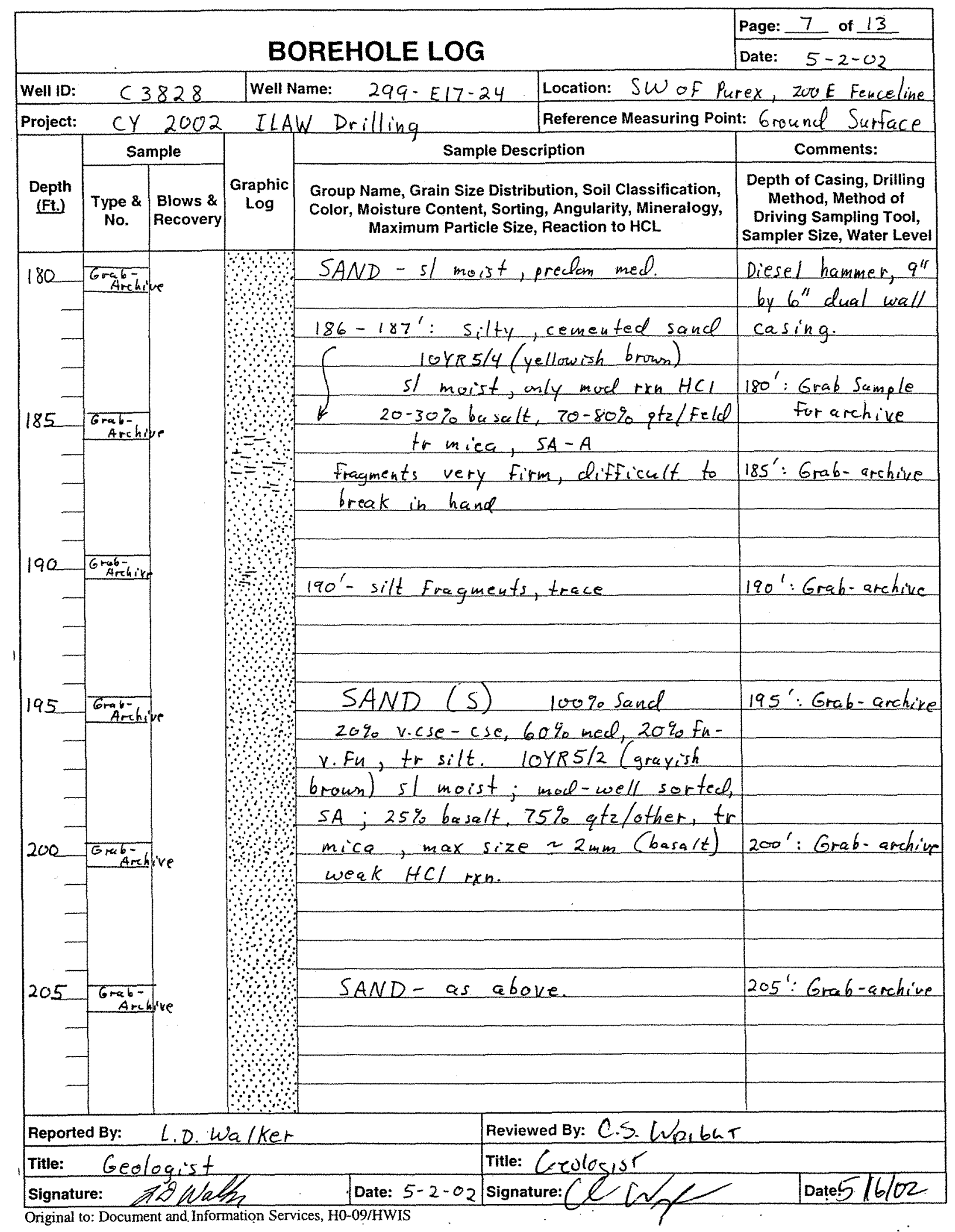

BHI-EE-183 (02-20-2002). 


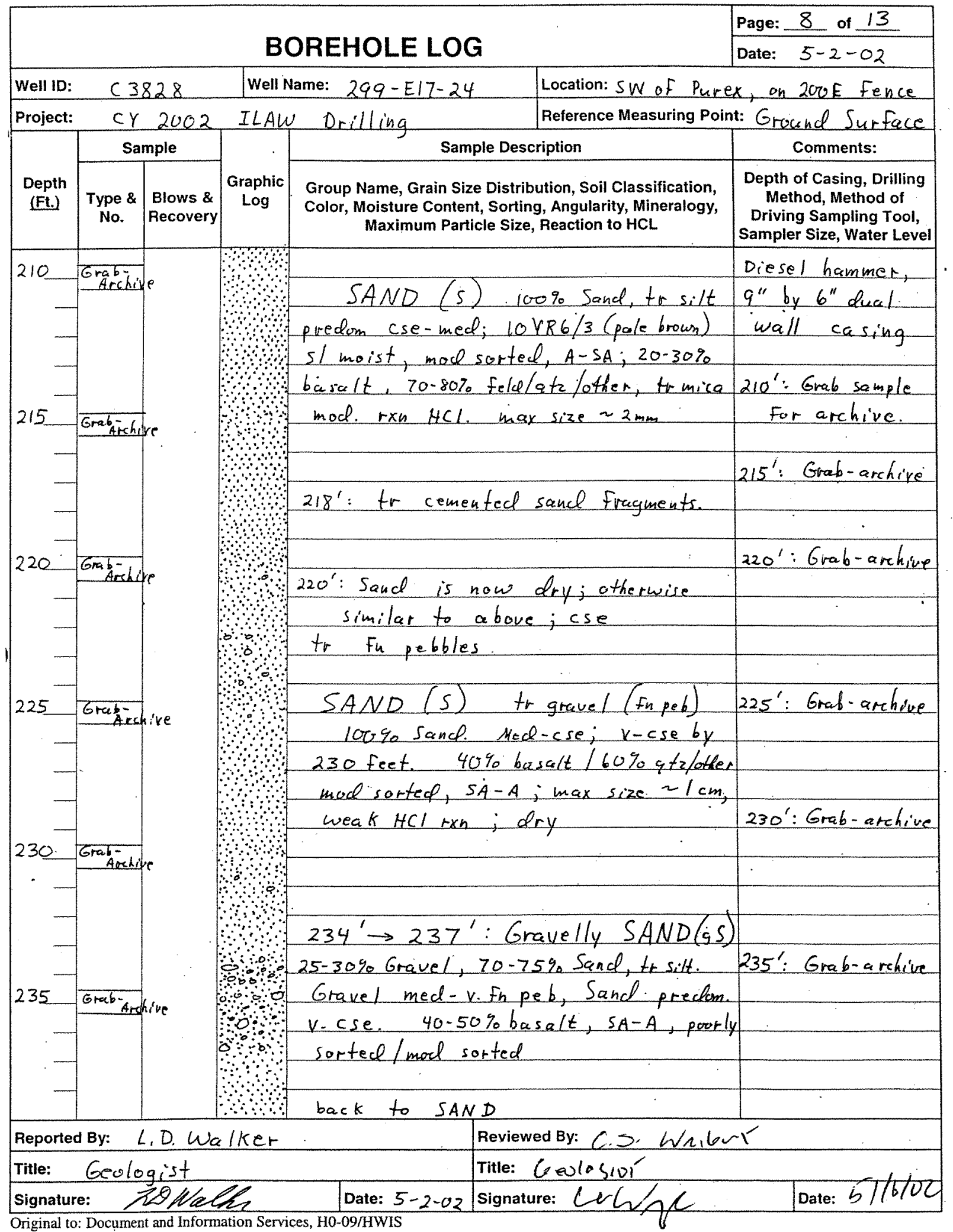

BHI-EE-183 (02-20-2002) 


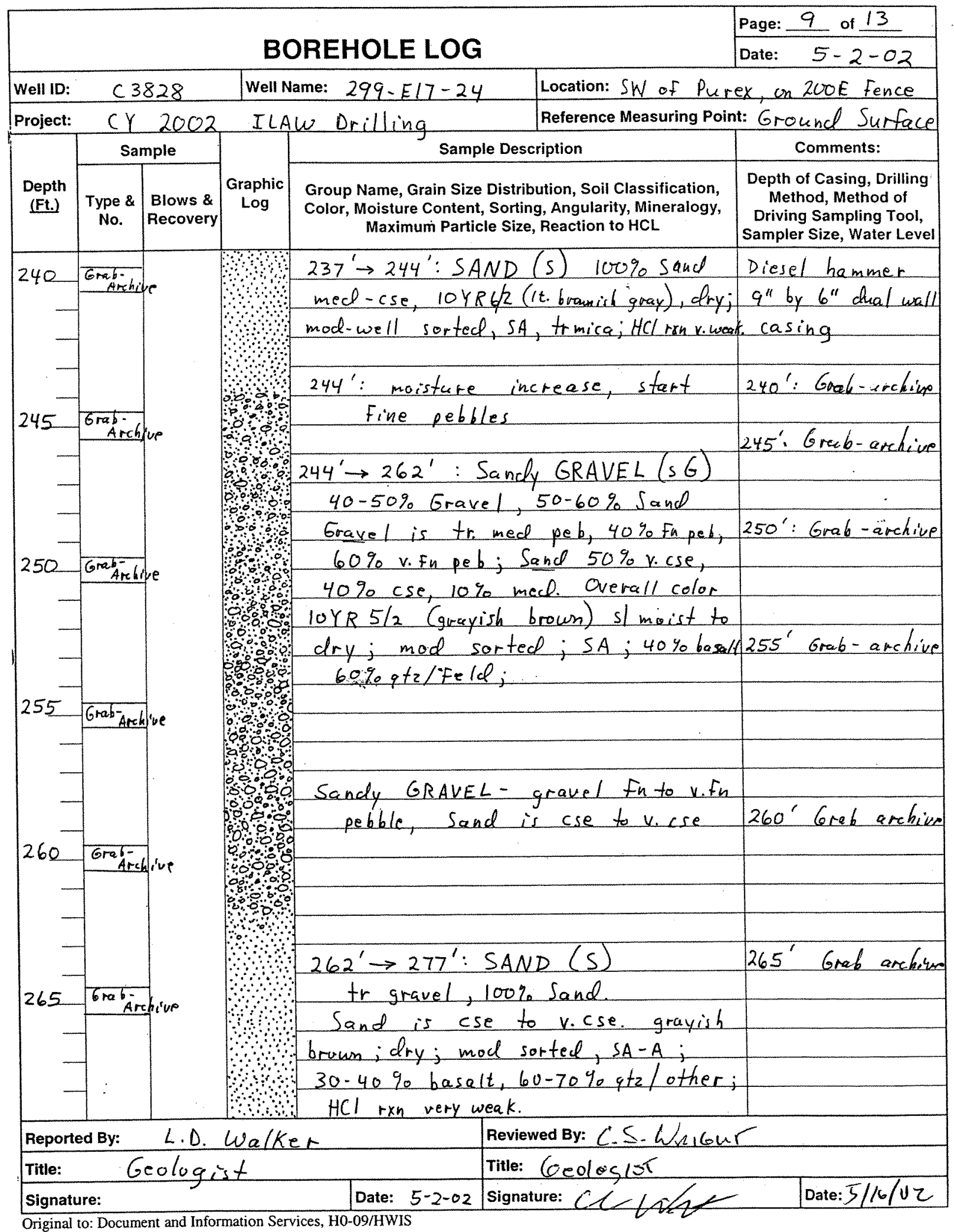

BHI-EE-183 (02-20:2002) 


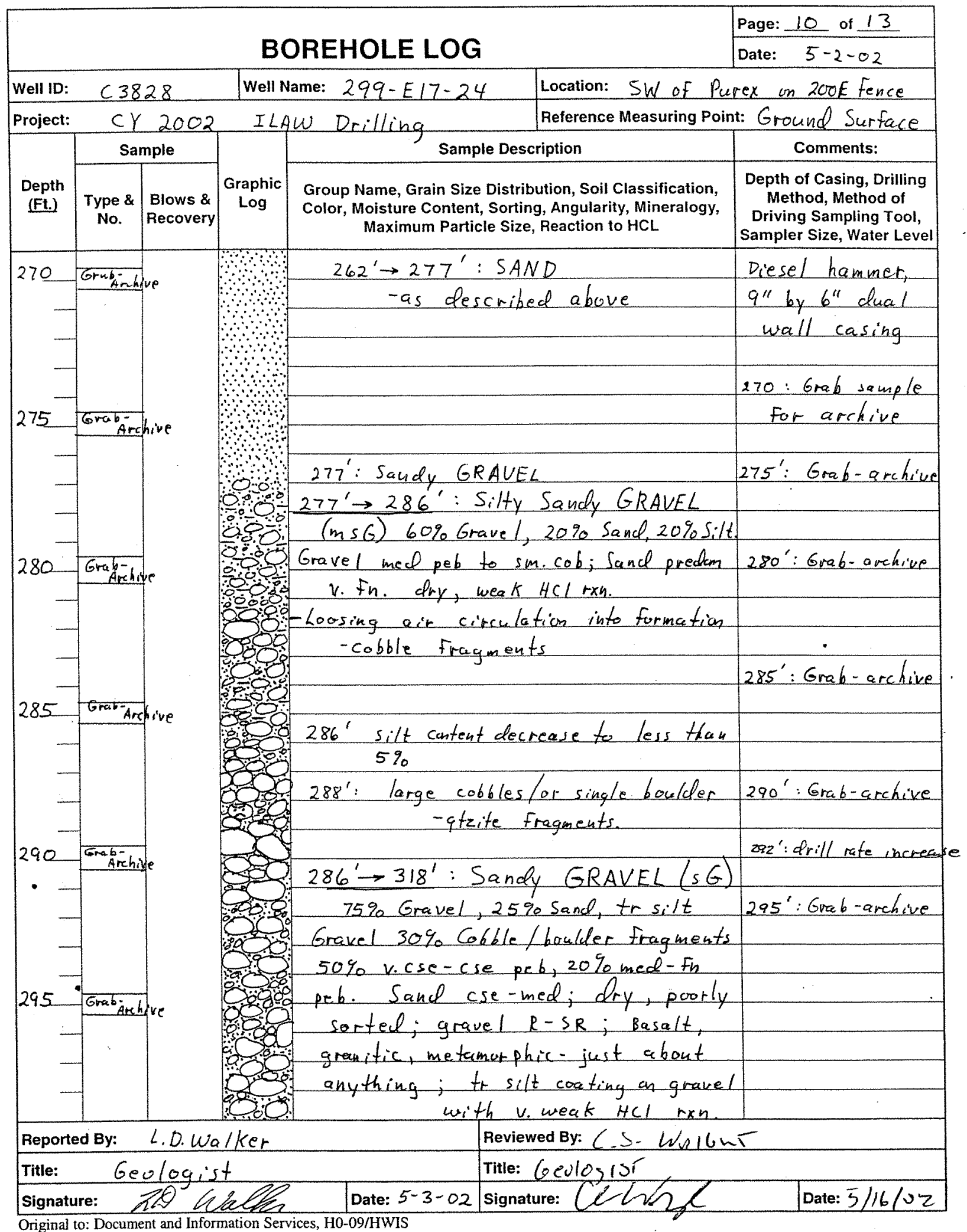

BHI-EE-183 (02-20-2002) 


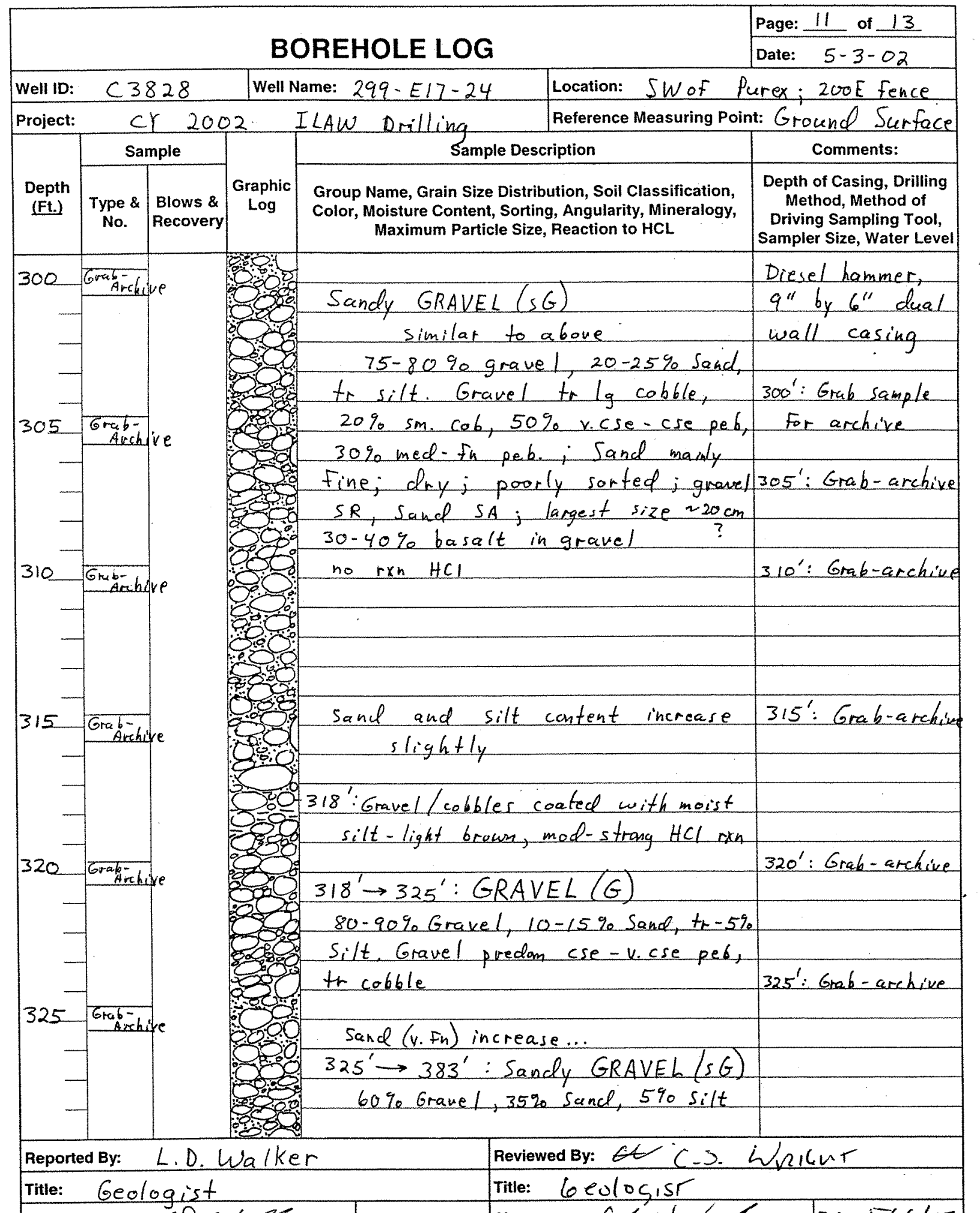

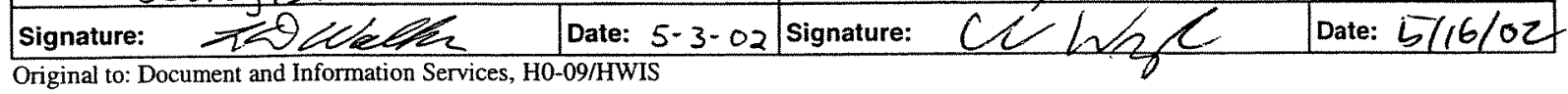

BHI-EE-183 (02-20-2002) 


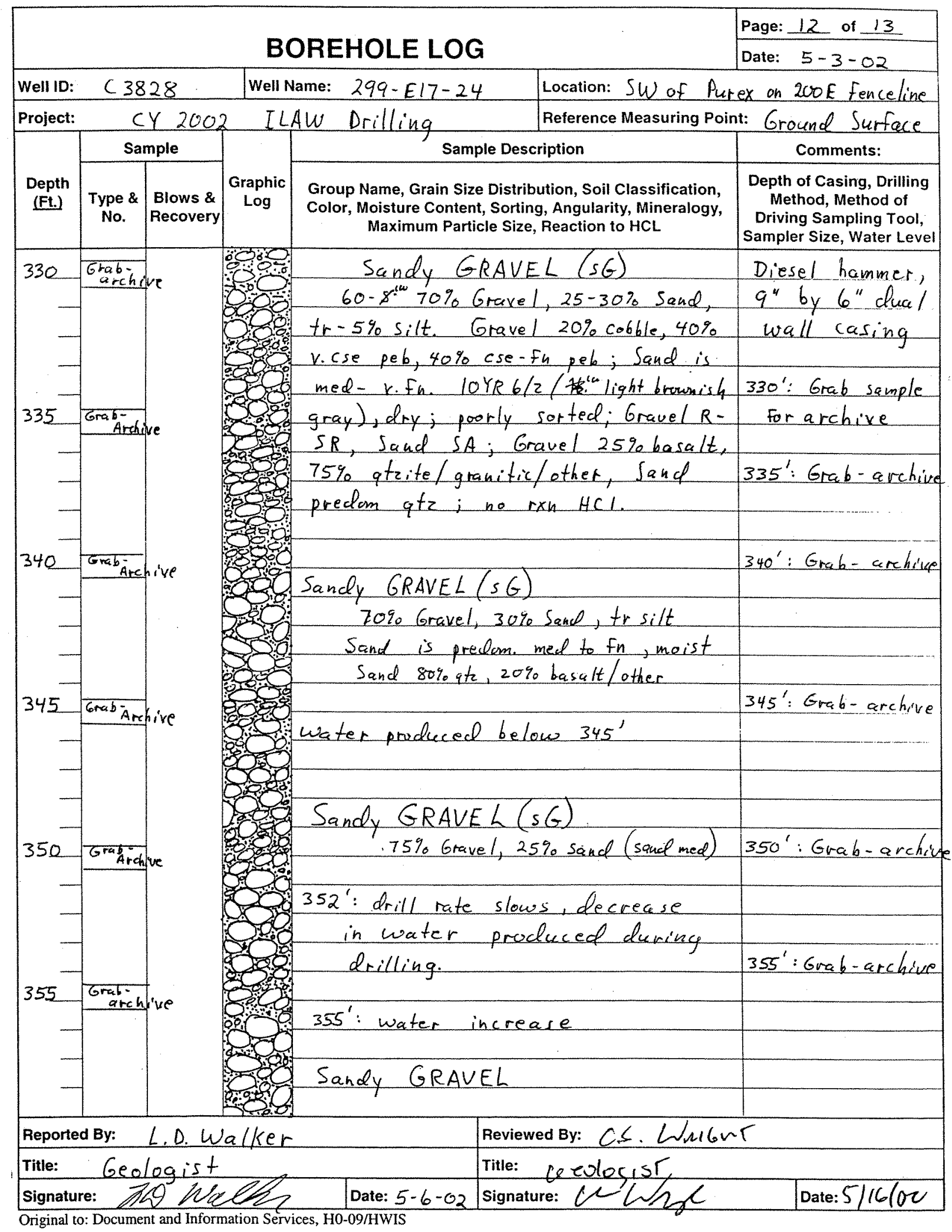

BHI-EE-183 (02-20-2002) 


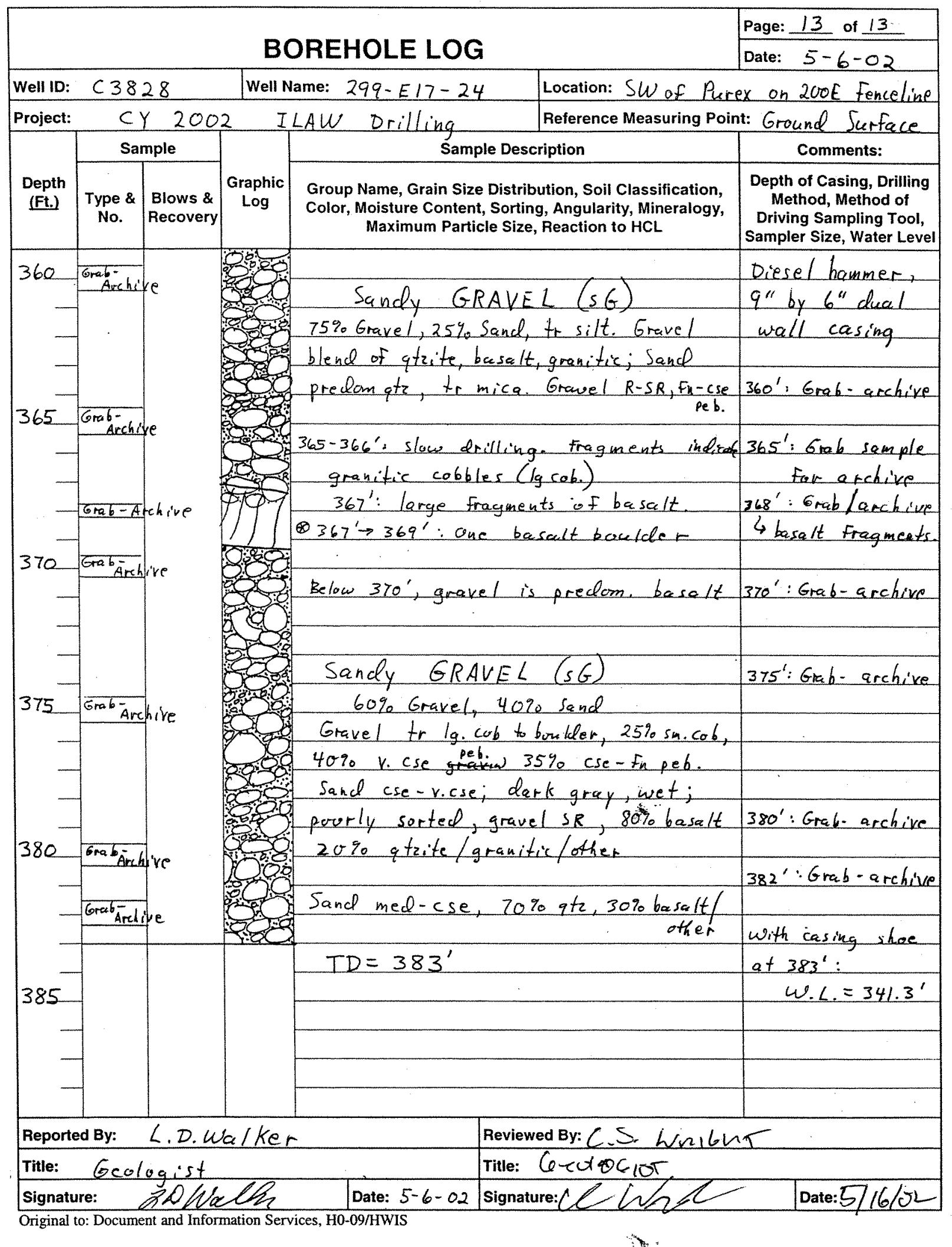

BHI-EE-183 (02-20-2002) 


\section{APPENDIX C}

\section{WELL DEVELOPMENT AND TESTING DATA}


BHI-01647

Rev. 0 


\section{WELL DEVELOPMENT AND TESTING DATA}

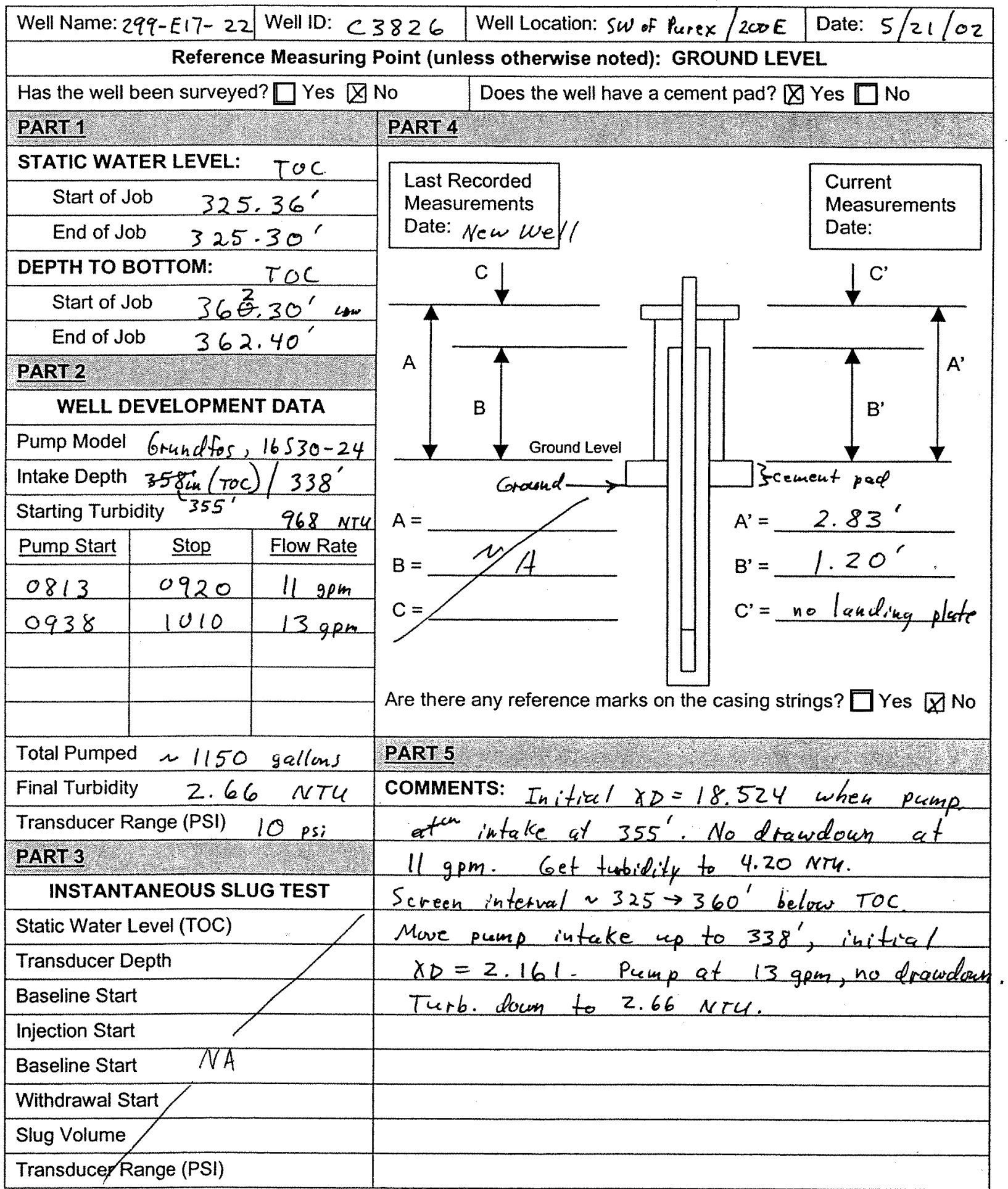

\begin{tabular}{|l|l|}
\hline Prepared by (print name): $\angle . D$. Walker & Signature: \\
\hline Reviewed by (print name): CS WRibur & Signature: \\
\hline
\end{tabular}

TO CHECK A BOX: Double click the box; select "Default Value - Checked" 
$(5 / 21 / 02)$

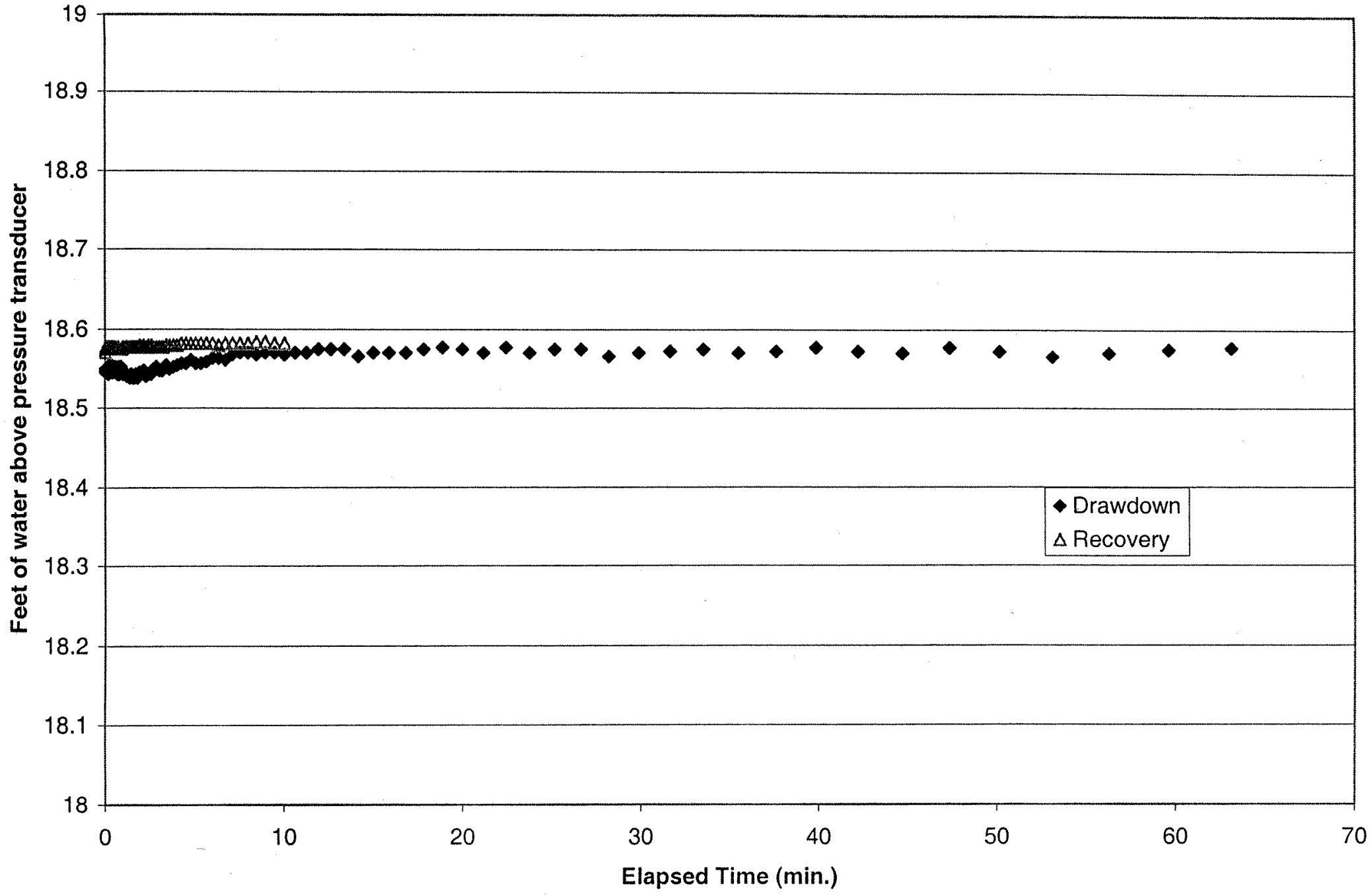




\section{WELL DEVELOPMENT AND TESTING DATA}

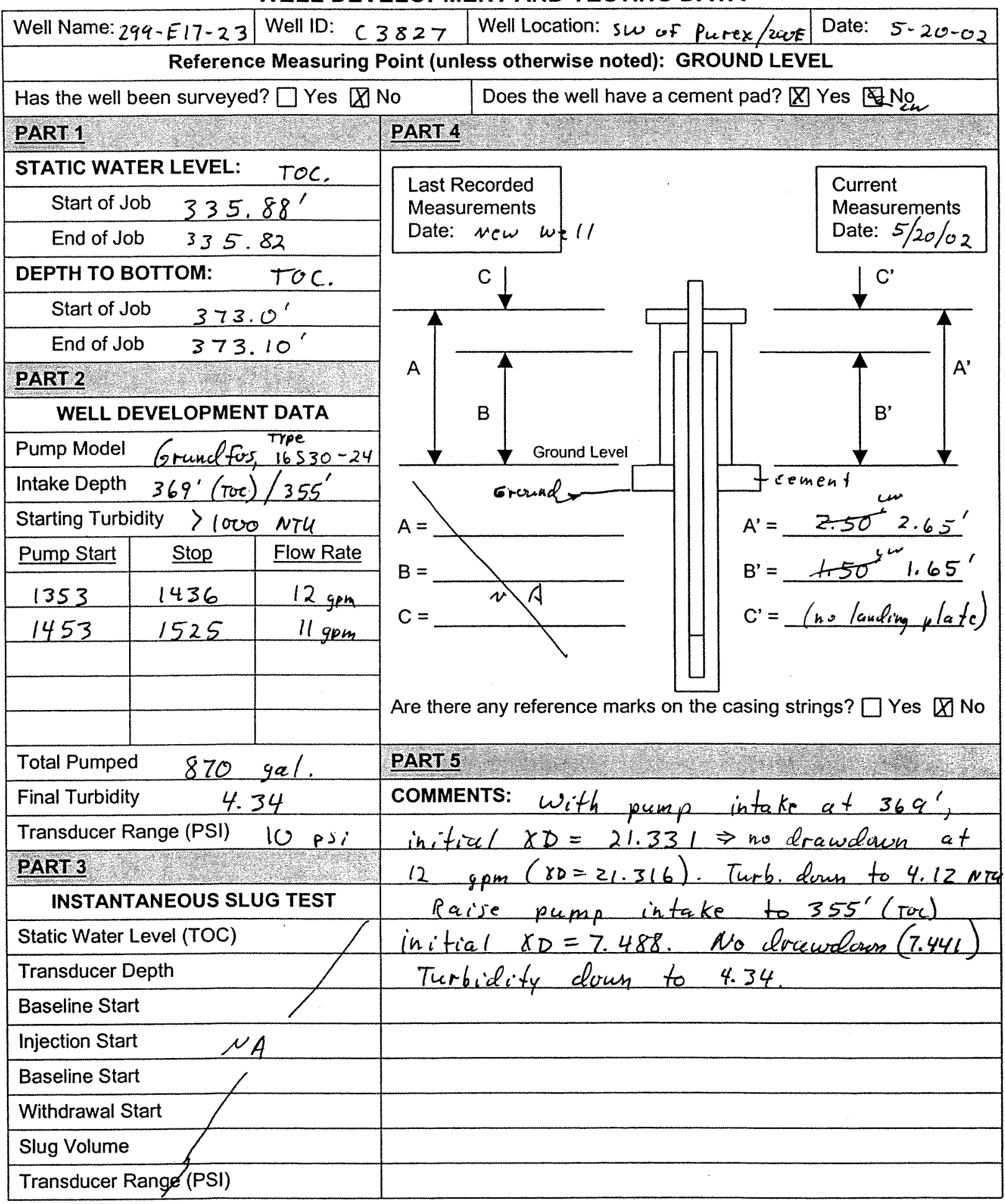

\begin{tabular}{|c|c|}
\hline Prepared by (print name): L. D. Wa (ker & Signature: $\pi D W$ Wa \\
\hline Reviewed by (print name): CS WrilonT & Signature: \\
\hline
\end{tabular}




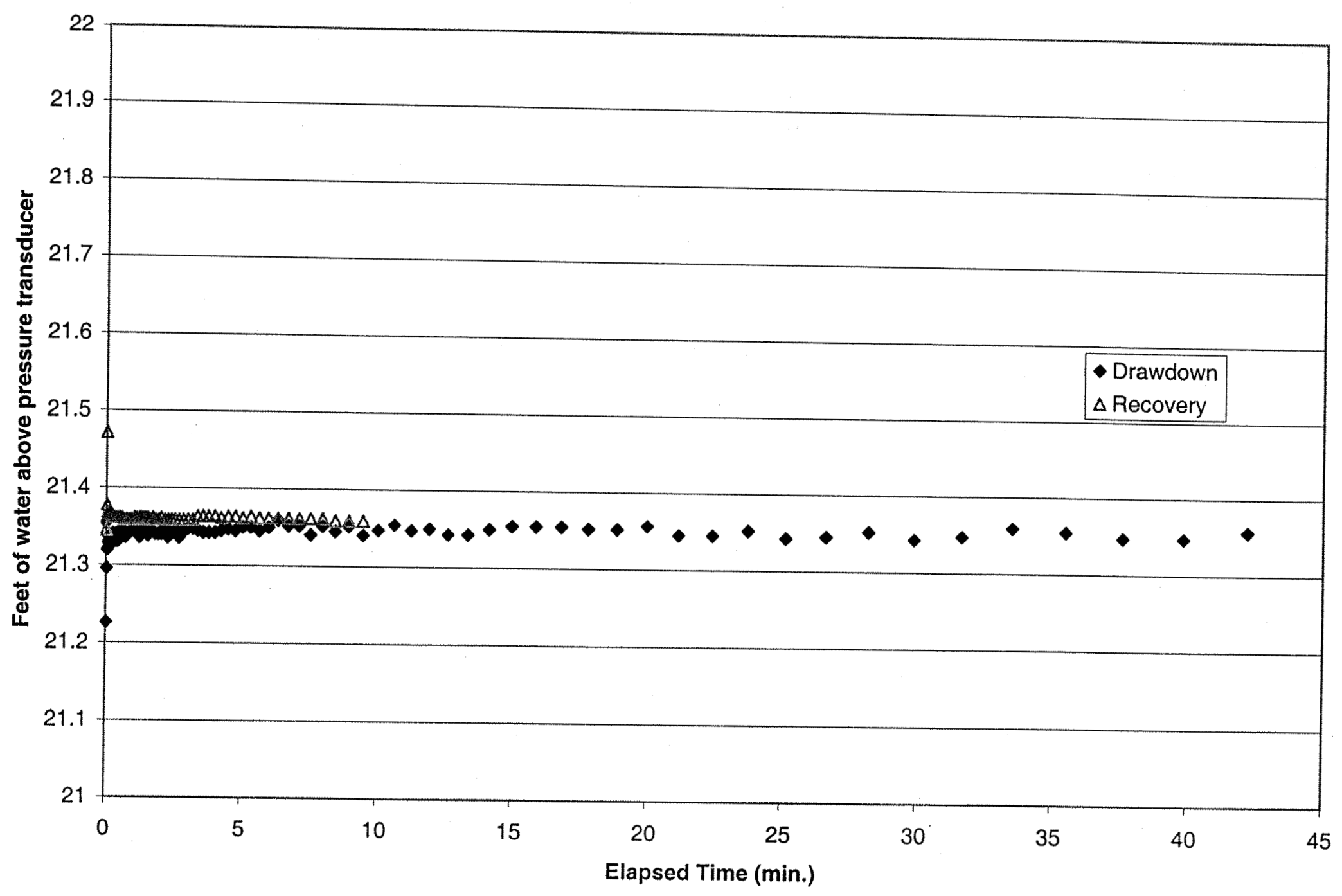




\section{WELL DEVELOPMENT AND TESTING DATA}

\begin{tabular}{|l|l|l|l|l|}
\hline Well Name: $299-E 17-25$ & Well ID: & C 3926 & Well Location: SW of Purex/200E & Date: $5-20-02$ \\
\hline
\end{tabular} Reference Measuring Point (unless otherwise noted): GROUND LEVEL

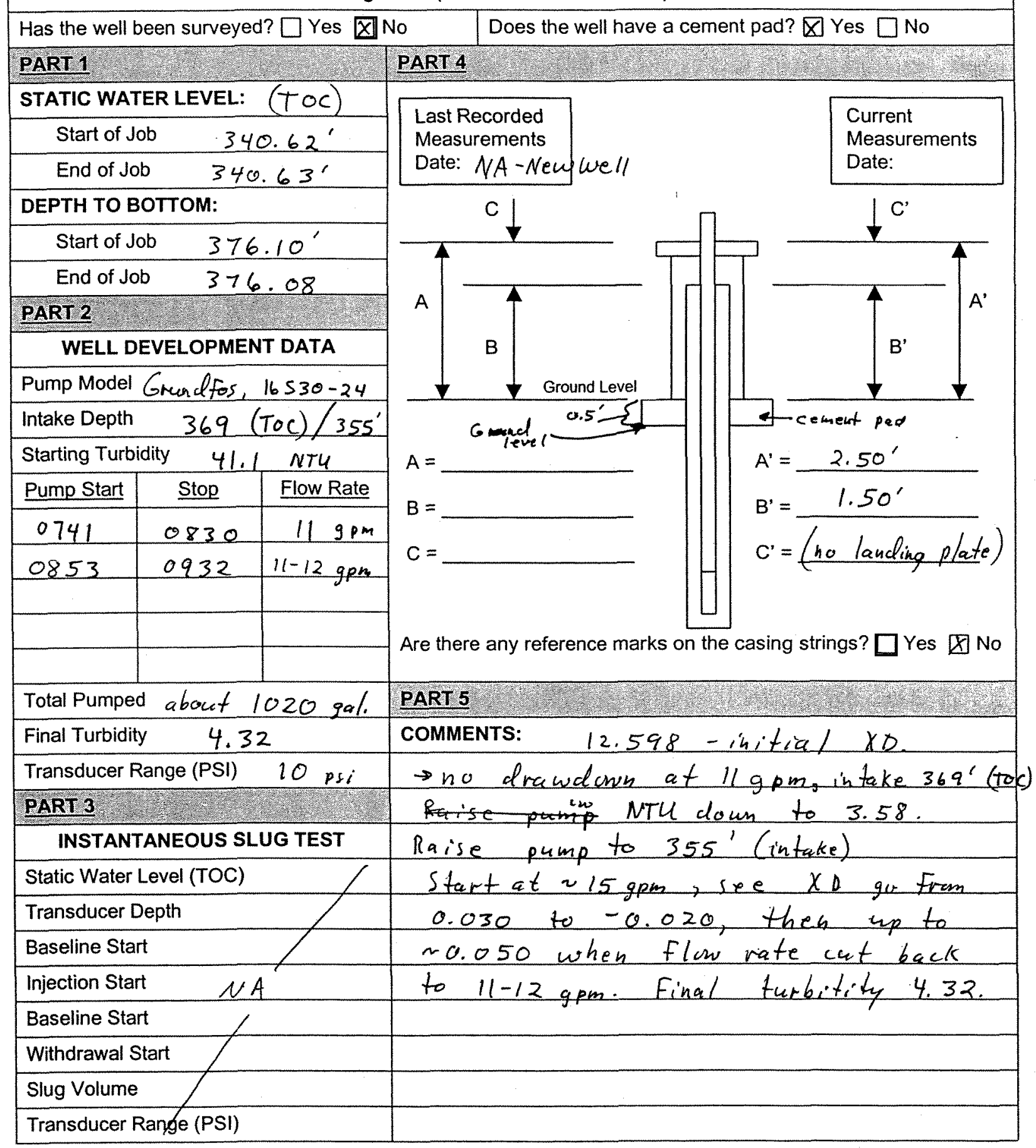

\begin{tabular}{|c|c|c|}
\hline Prepared by (print name): & L.D. Walkel & Signature: \\
\hline Reviewed by (print name): & cs Wnilur & Signature: $C C \&$ \\
\hline
\end{tabular}

TO CHECK A BOX: Double click the box; select "Default Value - Checked" 


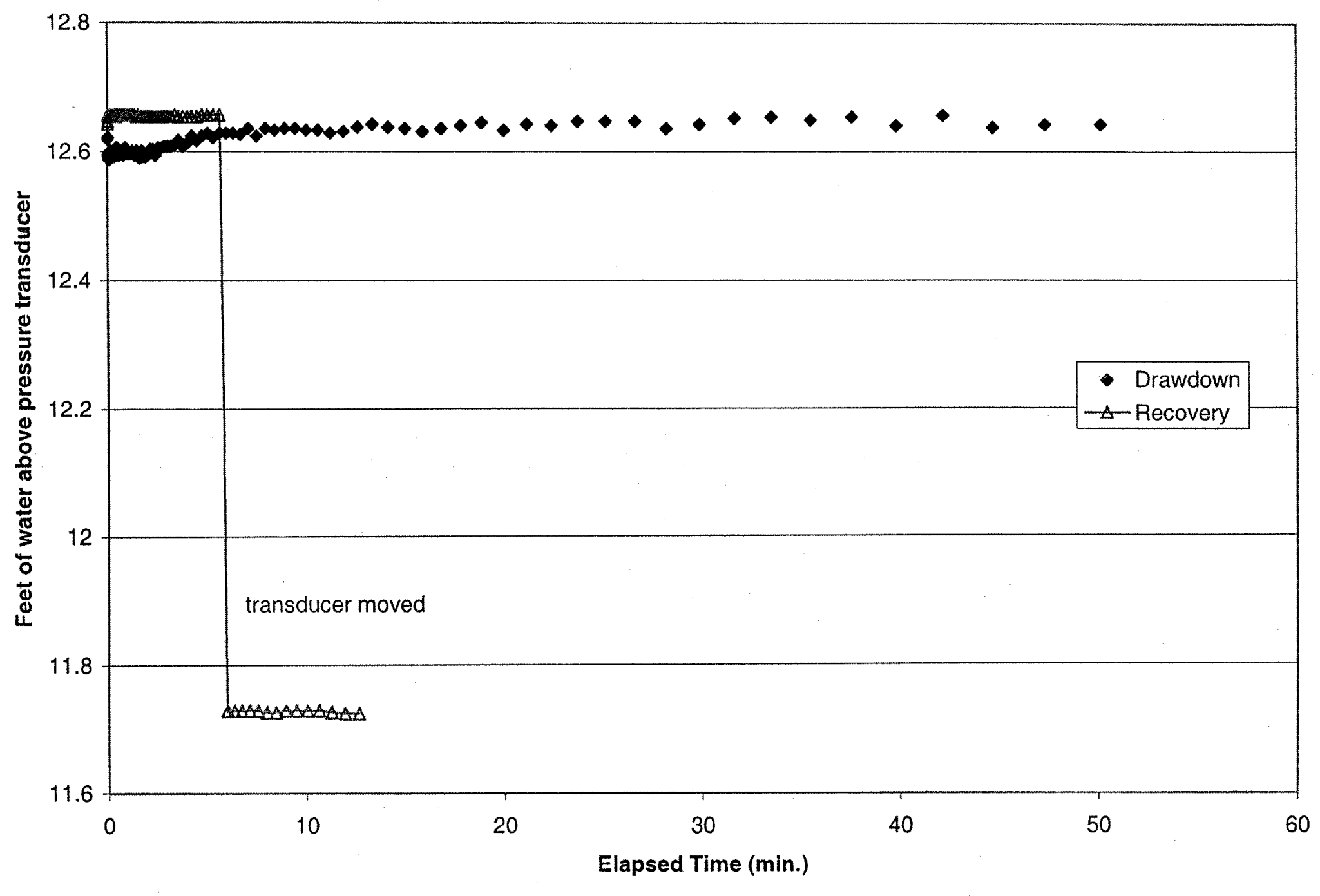




\section{APPENDIX D}

\section{SURVEY DATA REPORT SHEETS}


BHI-01647

Rev. 0 


\begin{tabular}{|c|c|c|c|c|c|c|}
\hline \multicolumn{7}{|c|}{ WELL SURVEY DATA REPORT } \\
\hline \multicolumn{4}{|c|}{ ERC Project: 22192} & \multicolumn{3}{|c|}{$\begin{array}{l}\text { Prepared By: Gary B. Wagner, P.L.S. } \\
\text { Company: Rogers Surveying, Inc. }\end{array}$} \\
\hline \multicolumn{4}{|c|}{ Date Requested: April 11, 2002} & \multicolumn{3}{|c|}{ Requestor: Robert Bone } \\
\hline \multicolumn{4}{|c|}{ Date of Survey: May 1,2002 } & \multicolumn{3}{|c|}{ Surveyor: Rogers Surveying, Inc. } \\
\hline \multicolumn{4}{|c|}{ ERC Point of Contact: Mr. Robert Bone } & \multicolumn{3}{|c|}{$\begin{array}{l}\text { Survey Co. Point of Contact: } \\
\text { Gary B. Wagner, P.L.S. }\end{array}$} \\
\hline \multirow{4}{*}{\multicolumn{4}{|c|}{$\begin{array}{l}\text { Description of Work: } \\
\text { Twenty-five Wells in the 100K, 100D \& } \\
\text { 200West (PFP) Areas of Hanford }\end{array}$}} & \multicolumn{3}{|c|}{ Horizontal Datum: NAD83(91) } \\
\hline & & & & \multicolumn{3}{|c|}{ Vertical Datum: NAVD88 } \\
\hline & & & & \multicolumn{3}{|c|}{ Units: Metric } \\
\hline & & & & \multicolumn{3}{|c|}{ Hanford Area Designation: $200 \mathrm{E}$} \\
\hline \multicolumn{7}{|c|}{ Coordinate System: Washington State Plane Coordinates (South Zone) } \\
\hline \multicolumn{7}{|c|}{$\begin{array}{l}\text { Horizontal Control Monuments: } \\
\text { "PUG" \& RSI GPS \#36 }\end{array}$} \\
\hline \multicolumn{7}{|c|}{$\begin{array}{l}\text { Vertical Control Monuments: } \\
\text { EXISTING WELL BRASS CAP AT WELL B8500 (299-E17-21) PREVIOUS WELL } \\
\text { SURVEY DATA REPORT }\end{array}$} \\
\hline Well Name & Well ID & Easting & \multicolumn{3}{|c|}{\begin{tabular}{|l|l|} 
Northing & Elevation \\
\end{tabular}} & \\
\hline \multirow[t]{3}{*}{ 299-E17-22 } & $\mathrm{C} 3826$ & 574841.090 & \multicolumn{2}{|c|}{135195.537} & & Center of Casing \\
\hline & & & \multirow{2}{*}{\multicolumn{2}{|c|}{135195.921}} & 221.458 & "X" on Rim \\
\hline & & 574841.067 & & & 220.589 & Brass Cap \\
\hline \multicolumn{7}{|l|}{ Notes: } \\
\hline \multicolumn{4}{|c|}{$\begin{array}{l}\text { Surveyor Statement: } \\
\text { I, Gary B. Wagner, a professional land surveyor } \\
\text { registered in the state of Washington (Registration } \\
\text { No. 30440), hereby certify that this report is based } \\
\text { on a field survey performed in May, } 2002 \text { under } \\
\text { my direct supervision, and that the data contained } \\
\text { here is true and correct. }\end{array}$} & \multicolumn{3}{|c|}{ Certification Seal } \\
\hline
\end{tabular}

BHI-EE-202 (09/98) 


\begin{tabular}{|c|c|c|c|c|c|c|}
\hline \multicolumn{7}{|c|}{ WELL SURVEY DATA REPORT } \\
\hline \multicolumn{4}{|c|}{ ERC Project: 22192} & \multicolumn{3}{|c|}{$\begin{array}{l}\text { Prepared By: Gary B. Wagner, P.L.S. } \\
\text { Company: Rogers Surveying, Inc. }\end{array}$} \\
\hline \multicolumn{4}{|c|}{ Date Requested: April 11, 2002} & \multicolumn{3}{|c|}{ Requestor: Robert Bone } \\
\hline \multicolumn{4}{|c|}{ Date of Survey: May 1,2002} & \multicolumn{3}{|c|}{ Surveyor: Rogers Surveying, Inc." } \\
\hline \multicolumn{4}{|c|}{ ERC Point of Contact: Mr. Robert Bone } & \multicolumn{3}{|c|}{$\begin{array}{l}\text { Survey Co. Point of Contact: } \\
\text { Gary B. Wagner, P.L.S. }\end{array}$} \\
\hline \multirow{4}{*}{\multicolumn{4}{|c|}{$\begin{array}{l}\text { Description of Work: } \\
\text { Twenty-five Wells in the } 100 \mathrm{~K}, 100 \mathrm{D} \& \\
\text { 200West (PFP) Areas of Hanford }\end{array}$}} & \multicolumn{3}{|c|}{ Horizontal Datum: NAD83(91) } \\
\hline & & & & \multicolumn{3}{|c|}{ Vertical Datum: NAVD88 } \\
\hline & & & & \multicolumn{3}{|c|}{ Units: Metric } \\
\hline & & & & \multicolumn{3}{|c|}{ Hanford Area Designation: $200 \mathrm{E}$} \\
\hline \multicolumn{7}{|c|}{ Coordinate System: Washington State Plane Coordinates (South Zone) } \\
\hline \multicolumn{7}{|c|}{$\begin{array}{l}\text { Horizontal Control Monuments: } \\
\text { "PUG" \& RSI GPS \#36 }\end{array}$} \\
\hline \multicolumn{7}{|c|}{$\begin{array}{l}\text { Vertical Control Monuments: } \\
\text { EXISTING WELL BRASS CAP AT WELL B8500 (299-E17-21) PREVIOUS WELL } \\
\text { SURVEY DATA REPORT }\end{array}$} \\
\hline Well Name & Well ID & Easting & \multicolumn{4}{|c|}{\begin{tabular}{|l|l|l|} 
Northing & Elevation & \\
\end{tabular}} \\
\hline \multirow[t]{3}{*}{ 299-E17-23 } & C3827 & 574694.483 & \multicolumn{2}{|c|}{134842.439} & & Center of Casing \\
\hline & & & & & 224.659 & "X" on Rim \\
\hline & & 574694.485 & & 4842.766 & 223.843 & Brass Cap \\
\hline \multicolumn{7}{|l|}{ Notes: } \\
\hline \multicolumn{4}{|c|}{$\begin{array}{l}\text { Surveyor Statement: } \\
\text { 1, Gary B. Wagner, a professional land surveyor } \\
\text { registered in the state of Washington (Registration } \\
\text { No. 30440), hereby certify that this report is based } \\
\text { on a field survey performed in May, } 2002 \text { under } \\
\text { my direct supervision, and that the data contained } \\
\text { here is true and correct. }\end{array}$} & \multicolumn{3}{|c|}{ Certification Seal } \\
\hline
\end{tabular}

BHI-EE-202 (09/98) 


\begin{tabular}{|c|c|c|c|c|c|c|}
\hline \multicolumn{7}{|c|}{ WELL SURVEY DATA REPORT } \\
\hline \multicolumn{4}{|c|}{ ERC Project: 22192} & \multicolumn{3}{|c|}{$\begin{array}{l}\text { Prepared By: Gary B. Wagner, P.L.S. } \\
\text { Company: Rogers Surveying, Inc. }\end{array}$} \\
\hline \multicolumn{4}{|c|}{ Date Requested: April 11, 2002} & \multicolumn{3}{|c|}{ Requestor: Robert Bone } \\
\hline \multicolumn{4}{|c|}{ Date of Survey: May 1,2002} & \multicolumn{3}{|c|}{ Surveyor: Rogers Surveying, Inc. } \\
\hline \multicolumn{4}{|c|}{ ERC Point of Contact: Mr. Robert Bone } & \multicolumn{3}{|c|}{$\begin{array}{l}\text { Survey Co. Point of Contact: } \\
\text { Gary B. Wagner, P.L.S. }\end{array}$} \\
\hline \multirow{4}{*}{\multicolumn{4}{|c|}{$\begin{array}{l}\text { Description of Work: } \\
\text { Twenty-five Wells in the } 100 \mathrm{~K}, 100 \mathrm{D} \& \\
200 \text { West (PFP) Areas of Hanford }\end{array}$}} & \multicolumn{3}{|c|}{ Horizontal Datum: NAD83(91) } \\
\hline & & & & \multicolumn{3}{|c|}{ Vertical Datum: NAVD88 } \\
\hline & & & & \multicolumn{3}{|c|}{ Units: Metric } \\
\hline & & & & \multicolumn{3}{|c|}{ Hanford Area Designation: $200 \mathrm{E}$} \\
\hline \multicolumn{7}{|c|}{ Coordinate System: Washington State Plane Coordinates (South Zone) } \\
\hline \multicolumn{7}{|c|}{$\begin{array}{l}\text { Horizontal Control Monuments: } \\
\text { "PUG" \& RSI GPS \#36 }\end{array}$} \\
\hline \multicolumn{7}{|c|}{$\begin{array}{l}\text { Vertical Control Monuments: } \\
\text { EXISTING WELL BRASS CAP AT WELL B8500 (299-E17-21) PREVIOUS WELL } \\
\text { SURVEY DATA REPORT }\end{array}$} \\
\hline Well Name & Well ID & Easting & \multicolumn{4}{|c|}{\begin{tabular}{|l|l|l|} 
Northing & Elevation & \\
\end{tabular}} \\
\hline \multirow[t]{3}{*}{ 299-E17-25 } & $\mathrm{C} 3926$ & 574515.185 & \multicolumn{2}{|c|}{134845.567} & & Center of Casing \\
\hline & & & \multirow{2}{*}{\multicolumn{2}{|c|}{134845.913}} & 225.791 & "X" on Rim \\
\hline & & 574515.171 & & & 225.028 & Brass Cap \\
\hline \multicolumn{7}{|l|}{ Notes: } \\
\hline \multicolumn{4}{|c|}{$\begin{array}{l}\text { Surveyor Statement: } \\
\text { I, Gary B. Wagner, a professional land surveyor } \\
\text { registered in the state of Washington (Registration } \\
\text { No. 30440), hereby certify that this report is based } \\
\text { on a field survey performed in May, } 2002 \text { under } \\
\text { my direct supervision, and that the data contained } \\
\text { here is true and correct. }\end{array}$} & \multicolumn{3}{|c|}{ Certification Seal } \\
\hline
\end{tabular}

BHI-EE-202 (09/98) 


\begin{tabular}{|c|c|c|c|c|c|c|}
\hline \multicolumn{7}{|c|}{ WELL SURVEY DATA REPORT } \\
\hline \multicolumn{4}{|c|}{ ERC Project: 22192} & \multicolumn{3}{|c|}{$\begin{array}{l}\text { Prepared By: Gary B. Wagner, P.L.S. } \\
\text { Company: Rogers Surveying, Inc. }\end{array}$} \\
\hline \multicolumn{4}{|c|}{ Date Requested: April 11,2002 } & \multicolumn{3}{|c|}{ Requestor: Robert Bone } \\
\hline \multicolumn{4}{|c|}{ Date of Survey: May 1,2002 } & \multicolumn{3}{|c|}{ Surveyor: Rogers Surveying, Inc. } \\
\hline \multicolumn{4}{|c|}{ ERC Point of Contact: Mr. Robert Bone } & \multicolumn{3}{|c|}{$\begin{array}{l}\text { Survey Co. Point of Contact: } \\
\text { Gary B. Wagner, P.L.S. }\end{array}$} \\
\hline \multirow{4}{*}{\multicolumn{4}{|c|}{$\begin{array}{l}\text { Description of Work: } \\
\text { Twenty-five Wells in the } 100 \mathrm{~K}, 100 \mathrm{D} \& \\
\text { 200West (PFP) Areas of Hanford }\end{array}$}} & \multicolumn{3}{|c|}{ Horizontal Datum: NAD83(91) } \\
\hline & & & & \multicolumn{3}{|c|}{ Vertical Datum: NAVD88. } \\
\hline & & & & \multicolumn{3}{|c|}{ Units: Metric } \\
\hline & & & & \multicolumn{3}{|c|}{ Hanford Area Designation: $200 \mathrm{E}$} \\
\hline \multicolumn{7}{|c|}{ Coordinate System: Washington State Plane Coordinates (South Zone) } \\
\hline \multicolumn{7}{|c|}{$\begin{array}{l}\text { Horizontal Control Monuments: } \\
\text { "PUG" \& RSI GPS \#36 }\end{array}$} \\
\hline \multicolumn{7}{|c|}{$\begin{array}{l}\text { Vertical Control Monuments: } \\
\text { EXISTING WELL BRASS CAP AT WELL B8500 (299-E17-21) PREVIOUS WELL } \\
\text { SURVEY DATA REPORT }\end{array}$} \\
\hline Well Name & Well ID & Easting & \multicolumn{4}{|c|}{\begin{tabular}{|l|l|l} 
Northing & Elevation & \\
\end{tabular}} \\
\hline \multicolumn{7}{|c|}{\begin{tabular}{l|l} 
ABANDONED & $\mathrm{C} 3828$ \\
\end{tabular}} \\
\hline & & 574518.125 & \multicolumn{2}{|c|}{134845.545} & 224.801 & BRASS CAP \\
\hline \multicolumn{7}{|c|}{$\begin{array}{l}\text { Notes: } \\
\text { C3828 IS AN ABANDONED WELL WITH NO CASING. }\end{array}$} \\
\hline \multicolumn{4}{|c|}{$\begin{array}{l}\text { Surveyor Statement: } \\
\text { I, Gary B. Wagner, a professional land surveyor } \\
\text { registered in the state of Washington (Registration } \\
\text { No. 30440), hereby certify that this report is based } \\
\text { on a field survey performed in May, } 2002 \text { under my } \\
\text { direct supervision, and that the data contained here } \\
\text { is true and correct. }\end{array}$} & \multicolumn{2}{|c|}{ Certification Seal } & \\
\hline
\end{tabular}

BHI-EE-202 (09/98) 


\section{DISTRIBUTION}

\section{$\underline{\text { ERC Team }}$}

K. C. Burgard, $\mathrm{CHG}$

L6-75

L. R. Curry, BHI

H0-09

L. M. Dittmer, BHI

H0-19

K. R. Fecht, BHI (2)

$\mathrm{H} 0-02$

T. L. Hottell, BHI

R4-03

R. L. Jackson, BHI

H0-19

F. M. Mann, CHG

H0-22

S. M. Muns, CHI (2)

H9-03

L. C. Swanson, CHI

H9-02

L. D. Walker, CHI

H9-02

C. S. Wright, CHI

H0-19

$\underline{\text { PNNL }}$

S. Reidel

K6-81

Document and Information Services (3)

H0-09

DOE-RL Public Reading Room

$\mathrm{H} 2-53$

Hanford Technical Library

P8-55 


\section{Appendix B}

Description of Core from Borehole C3826 


\section{Appendix B}

\section{Description of Core from Borehole C3826}

\begin{tabular}{|c|c|}
\hline $\begin{array}{l}\text { Depth Below Surface } \\
\text { (feet and inches) }\end{array}$ & Description of Core from Borehole C3826 \\
\hline $0^{\prime}$ to 8 ' & No core recovered. \\
\hline $8^{\prime}$ to $9^{\prime}$ & $\begin{array}{l}25 \% \text { recovered - not opened. Moist, loose, no internal structure preserved. Medium- to } \\
\text { coarse-grained sand; } 75 \% \text { basalt and } 25 \% \text { felsic; subrounded to subangular; poorly sorted; } \\
\text { color } 10 \text { YR } 5 / 2 \text {. }\end{array}$ \\
\hline $9^{\prime}-10^{\prime}$ & $\begin{array}{l}55 \% \text { recovered. Slightly moist, loose, disturbed. (Opened previously for LBL oxygen } \\
\text { isotope study.) Coarse to medium-grained sand: } 50 \% \text { coarse, } 40 \% \text { medium-grained, } 7 \% \\
\text { fine-grained, } 3 \% \text { very coarse, with pebbles up to } 0.4 \text { in (diameter); well-cemented zone } \\
1.2 \text { to } 1.6 \text { in wide (previously wider?) in the middle of the core (at 9' } 6 \text { "); material above } \\
\text { this zone is also slightly cemented with } \mathrm{CaCO}_{3} ; \text { material below this zone is slightly more } \\
\text { moist, finer-grained, and shows only a moderate reaction to } \mathrm{HCl} ; 40 \% \text { basalt and } 60 \% \\
\text { felsic; subangular to subrounded; color } 10 \mathrm{YR} 5 / 2 \text {. }\end{array}$ \\
\hline $10^{\prime}$ to $11^{\prime}$ & $\begin{array}{l}70 \% \text { recovered. Dry, loose, disturbed. (Opened previously for LBL oxygen isotope } \\
\text { study.) Coarse to very coarse sand: } 5-10 \% \text { gravel, with rounded to subrounded pebbles } \\
\text { up to } 1 \text { in (diameter), } 30 \% \text { very coarse, } 45 \% \text { coarse, } 15 \% \text { medium-grained, trace of silt; } \\
50 \% \text { basalt and } 50 \% \text { felsic; subangular to angular; color } 10 \text { YR } 5 / 2 \text {. }\end{array}$ \\
\hline $11^{\prime}$ to $12^{\prime}$ & $\begin{array}{l}95 \% \text { recovered. Moist, loose, undisturbed. Coarse-grained sand with minor silt, grains up } \\
\text { to } 0.15 \text { in (diameter); } 50-60 \% \text { basalt and } 40-50 \% \text { felsic; subangular; fairly sorted; color } \\
10 \text { YR5/2. } \\
\text { At } 11 \text { '7' is a } 0.8 \text {-in--thick layer of silt and clay (possible soil?), separating coarse material } \\
\text { above from finer material below. }\end{array}$ \\
\hline $12^{\prime}$ to $13^{\prime}$ & $\begin{array}{l}50 \% \text { recovered-not opened. Moist, loose, no internal structure preserved. Medium- to } \\
\text { coarse-grained sand; } 50-70 \% \text { basalt and } 30-50 \% \text { felsic; subrounded to subangular; poorly } \\
\text { sorted; color } 10 \text { YR } 5 / 2 \text {. }\end{array}$ \\
\hline $13^{\prime}$ to $14^{\prime}$ & $\begin{array}{l}75 \% \text { recovered. Dry, loose, disturbed. (Opened previously for LBL oxygen isotope } \\
\text { study.) Coarse- to medium-grained sand: } 45 \% \text { coarse, } 45 \% \text { medium- and fine-grained, } \\
10 \% \text { very coarse, with grains up to } 0.16 \text { in (diameter); } 45 \% \text { basalt and } 55 \% \text { felsic; angular } \\
\text { to subangular (large grains mostly angular); color } 10 \mathrm{YR} 5 / 2 \text {. }\end{array}$ \\
\hline $14^{\prime}$ to $15^{\prime}$ & $\begin{array}{l}95 \% \text { recovered. Slightly moist, undisturbed, compact. Three color bands apparent. From } \\
14 \text { ' to } 14{ }^{\prime} \text { ": color band of medium- to coarse-grained sand; } 50 \% \text { basalt and } 50 \% \text { felsic; } \\
\text { subangular to subrounded; unsorted. From } 142^{2} \text { " to } 14 ' 7.5 ": \text { fine- to medium-grained } \\
\text { sand; compacted, with graded bed fining upwards, each } \sim 0.8 \text { in thick; subangular to } \\
\text { subrounded, well-sorted. At the base of this band is a very fine clay zone } 0.08 \text { in thick } \\
\text { that effervesces. From } 144^{\prime} 7.5 \text { " to the bottom of the core: coarse sand, with grains up to } \\
0.2 \text { in (diameter); } 60 \% \text { basalt and } 40 \% \text { felsic; subangular; poorly sorted. Color } 10 \mathrm{YR} 5 / 2 \text {. }\end{array}$ \\
\hline
\end{tabular}




\begin{tabular}{|c|c|}
\hline $\begin{array}{l}\text { Depth Below Surface } \\
\text { (feet and inches) }\end{array}$ & Description of Core from Borehole C3826 \\
\hline $15^{\prime}$ to $16^{\prime}$ & $\begin{array}{l}95 \% \text { recovered. Dry, slightly compact. Medium- to coarse-grained sand; } 50 \% \text { basalt and } \\
50 \% \text { felsic; subangular to subrounded; well-sorted; } 10 \text { YR } 5 / 2 \text {. Bands of fine- to medium- } \\
\text { grained sand are apparent, and spaced every } 1 \text { to } 2 \text { in. The most prominent bands are at } \\
15^{\prime} 8^{\prime} \text { " and } 15^{\prime} 9 \text { '. A fairly compact zone is found between } 15^{\prime} 6.5^{\prime} \text { and } 15^{\prime} 9.5^{\prime} \text {. }\end{array}$ \\
\hline $16^{\prime}$ to $17^{\prime}$ & $\begin{array}{l}50 \% \text { recovered. Dry, loose, disturbed. (Opened previously for LBL oxygen isotope } \\
\text { study.) Medium- to fine-grained sand: } 55 \% \text { fine-grained, } 40 \% \text { medium-grained, } 5 \% \\
\text { coarse, } 2 \% \text { very coarse, with grains of basalt up to } 0.16 \text { in (diameter); } 30-35 \% \text { basalt and } \\
65-70 \% \text { felsic; subangular to subrounded; } 10 \text { YR } 5 / 2 \text {. }\end{array}$ \\
\hline $17^{\prime}$ to $18^{\prime}$ & $\begin{array}{l}90 \text { to } 95 \% \text { recovered. Dry, loose, undisturbed. Medium- to coarse-grained sand; } 50 \% \\
\text { basalt and } 50 \% \text { felsic; subangular to subrounded; well-sorted; } 10 \text { YR } 5 / 2 \text {. Pebble layers } \\
\sim 0.5 \text { in thick are found at } 17^{\prime} 2.5^{\prime \prime} \text { and } 17^{\prime} 5.5^{\prime} ; \text {; both are basalt-dominated, with pebbles up } \\
\text { to } 1 \text { in (diameter). }\end{array}$ \\
\hline $18^{\prime}$ to $19^{\prime}$ & $\begin{array}{l}90 \text { to } 95 \% \text { recovered. Dry, uncompacted, slightly disturbed. Medium- to coarse-grained } \\
\text { sand; } 50 \% \text { basalt and } 50 \% \text { felsic; subangular to subrounded; well-sorted; } 10 \text { YR } 5 / 2 \text {. } \\
\text { Layers of coarser sand present. }\end{array}$ \\
\hline $19^{\prime}$ to $20^{\prime}$ & $\begin{array}{l}60 \% \text { recovered. Dry, loose, disturbed. (Opened previously for LBL oxygen isotope } \\
\text { study.) Medium-grained sand: } 75 \% \text { medium-grained, } 10 \% \text { fine-grained, } 10 \% \text { coarse, } 5 \% \\
\text { very coarse, with granitic pebbles up to } 0.1 \text { in (diameter); } 30 \text { to } 40 \% \text { basalt and } 60 \text { to } 70 \% \\
\text { felsic; angular to subangular; moderately well-sorted; } 10 \text { YR } 5 / 2 \text {. }\end{array}$ \\
\hline $20^{\prime}$ to $20^{\prime} 6^{\prime \prime}$ & No recovery. \\
\hline $20^{\prime} 6 "$ to $21^{\prime} 6 "$ & $\begin{array}{l}30 \% \text { recovered-not opened. Dry, loosely packed, internal structure not preserved. } \\
\text { Medium-grained sand, grains up to } 0.15 \text { in (diameter); } 50 \% \text { basalt and } 50 \% \text { felsic; } \\
\text { subrounded to subangular; color } 10 \text { YR } 5 / 2 \text {. }\end{array}$ \\
\hline $21^{\prime} 6 "$ " to $22^{\prime} 6^{\prime \prime}$ & $\begin{array}{l}90 \% \text { recovered. Dry, partially disturbed, uncompacted. Medium- to coarse-grained sand } \\
\text { with minor silt, grains up to } 0.6 \text { in (diameter); } 50 \% \text { basalt and } 50 \% \text { felsic; subangular to } \\
\text { subrounded; well-sorted; color } 10 \text { YR } 5 / 2 \text {. Some coherent silty nodules present. }\end{array}$ \\
\hline $22^{\prime} 6 "$ to $23^{\prime} 6^{\prime \prime}$ & $\begin{array}{l}80 \% \text { recovered. Dry, disturbed, loose. Medium-grained sand with some silt present; } 50 \% \\
\text { basalt and } 50 \% \text { felsic; subangular to subrounded; poorly sorted; color } 10 \text { YR } 5 / 2 \text {. }\end{array}$ \\
\hline $23^{\prime} 6^{\prime \prime}$ to $24^{\prime} 6^{\prime \prime}$ & $\begin{array}{l}90 \% \text { recovered. Very slightly moist, loose, undisturbed. Medium- to coarse-grained sand, } \\
\text { grains up to } 0.15 \text { in (diameter); } 50 \% \text { basalt and } 50 \% \text { felsic; subangular to subrounded; } \\
\text { fairly well-sorted; color } 10 \text { YR } 5 / 2 \text {. Color band at } 23 \text { ' } 7 \text { ' composed of a } 0.4 \text {-in thick silt- } \\
\text { rich (up to } 50 \% \text { silt) layer; effervesces. }\end{array}$ \\
\hline $24^{\prime} 6^{\prime \prime}$ to $25^{\prime}$ & No recovery. \\
\hline $25^{\prime}$ to $26^{\prime}$ & $\begin{array}{l}\text { Partially recovered. Dry, loose, disturbed. (Opened previously for LBL oxygen isotope } \\
\text { study.) Medium- to coarse-grained sand: } 58 \% \text { coarse, } 40 \% \text { medium-grained, } 2 \% \text { very } \\
\text { coarse; } 50 \% \text { basalt and } 50 \% \text { felsic; subangular to angular; color } 10 \text { YR } 5 / 2 \text {. }\end{array}$ \\
\hline $26^{\prime}$ to $27^{\prime}$ & $\begin{array}{l}85 \% \text { recovered. Dry, loose. Medium-grained sand with minor silt; } 50 \% \text { basalt and } 50 \% \\
\text { felsic; subangular to subrounded; poorly sorted; color } 10 \text { YR } 5 / 2 \text {. }\end{array}$ \\
\hline $27^{\prime}$ to $28^{\prime}$ & $\begin{array}{l}85-90 \% \text { recovered. Dry, loose. Medium- to coarse-grained sand, grains up to } 0.07 \text { in } \\
\text { (diameter); } 50 \% \text { basalt and } 50 \% \text { felsic; subangular to subrounded; well-sorted; color } \\
10 \text { YR5/2. From } 17^{\prime} 8.8 \text { " to } 17^{\prime} 9.5^{\prime} \text { is a light color band that is finer (contains more silt) } \\
\text { than the rest of the core, and is not compact or coherent. }\end{array}$ \\
\hline
\end{tabular}




\begin{tabular}{|c|c|}
\hline $\begin{array}{l}\text { Depth Below Surface } \\
\text { (feet and inches) }\end{array}$ & Description of Core from Borehole C3826 \\
\hline $28^{\prime}$ to $29^{\prime}$ & $\begin{array}{l}\text { Partially recovered. Dry, loose, disturbed. (Opened previously for LBL oxygen isotope } \\
\text { study.) Medium- to coarse-grained sand: } 55 \% \text { medium-grained, } 40 \% \text { coarse, } 2 \% \text { very } \\
\text { coarse, } \sim 2 \% \text { fine-grained; } 40 \% \text { basalt and } 60 \% \text { felsic; subangular to angular; moderately } \\
\text { well-sorted; color } 10 \text { YR } 5 / 2 \text {. }\end{array}$ \\
\hline $29^{\prime}$ to $29^{\prime} 6^{\prime \prime}$ & No recovery. \\
\hline $29^{\prime} 6 "$ " to $30^{\prime} 6 "$ & $\begin{array}{l}80-85 \% \text { recovered-not opened. Dry, loose, disturbed. Medium- to coarse-grained sand } \\
\text { with minor silt; subangular to subrounded; poorly sorted; color } 10 \text { YR } 5 / 2 \text {. }\end{array}$ \\
\hline $30^{\prime} 6 "$ " to $31^{\prime} 6^{\prime \prime}$ & 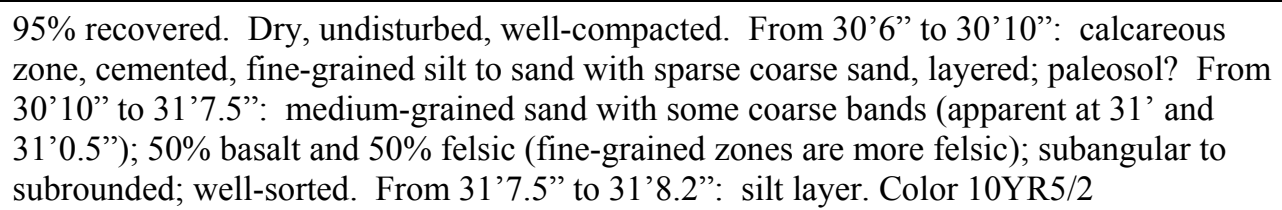 \\
\hline $31^{\prime} 6^{\prime \prime}$ to $32^{\prime} 6^{\prime \prime}$ & 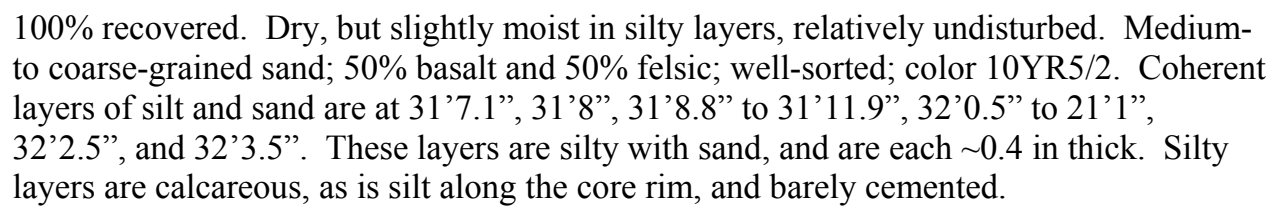 \\
\hline $32^{\prime} 6 "$ to $33^{\prime} 6^{\prime \prime}$ & $\begin{array}{l}75 \% \text { recovered. Dry, loose, disturbed. (Opened previously for LBL oxygen isotope } \\
\text { study.) Medium- to coarse-grained sand: } 60 \% \text { medium-grained, } 35 \% \text { coarse, } 5 \% \text { fine- } \\
\text { grained; } 40 \% \text { basalt and } 60 \% \text { felsic; subangular to angular; moderately well-sorted; color } \\
\text { 10YR } 5 / 2 \text {. }\end{array}$ \\
\hline $33^{\prime} 6^{\prime \prime}$ to $34^{\prime}$ & No recovery. \\
\hline $34^{\prime}$ to $35^{\prime}$ & $\begin{array}{l}85 \% \text { recovered. Dry, loose, uncompacted. Coarse to very coarse sand: } 30 \% \text { very coarse, } \\
60 \% \text { coarse, } 10 \% \text { medium-grained; } 50 \% \text { basalt and } 50 \% \text { felsic; subangular to angular; } \\
\text { moderately well-sorted; color } 10 \text { YR } 5 / 2 \text {. }\end{array}$ \\
\hline $35^{\prime}$ to $36^{\prime}$ & $\begin{array}{l}85 \% \text { recovered. Dry, loose. Coarse sand: } 10 \% \text { very coarse, } 80 \% \text { coarse, } 10 \% \text { medium- } \\
\text { grained; } 40 \% \text { basalt and } 60 \% \text { felsic; moderately well-sorted; } 10 \text { YR } 5 / 2 \text { color } 10 \text { YR5 } 5 \text {. }\end{array}$ \\
\hline $36^{\prime}$ to $37^{\prime}$ & $\begin{array}{l}90 \% \text { recovered. Dry, very loose. Medium- to coarse-grained sand; } 50 \% \text { basalt and } 50 \% \\
\text { felsic; subangular to subrounded; well sorted; } 10 \text { YR } 5 / 2 \text { color } 10 \text { YR } 5 / 2 \text {. }\end{array}$ \\
\hline $37^{\prime}$ to $38^{\prime}$ & $\begin{array}{l}85 \% \text { recovered. Dry, loose, uncompacted. Medium- to coarse-grained sand; } 50 \% \text { basalt } \\
\text { and } 50 \% \text { felsic; subangular to subrounded; well-sorted; color } 10 \text { YR } 5 / 2 \text {. }\end{array}$ \\
\hline $38^{\prime}$ to $39^{\prime}$ & $\begin{array}{l}85 \% \text { recovered. Dry, compacted. Fine- to medium-grained sand; } 50 \% \text { basalt and } 50 \% \\
\text { felsic; well sorted; } 10 \mathrm{YR} 5 / . \text { Numerous layers of } \mathrm{CaCO}_{3} \text {-rich zones, from } 0.1 \text { to } 1.5 \text { in } \\
\text { wide. Color } 10 \mathrm{YR} 5 / 2\end{array}$ \\
\hline $39^{\prime}$ to $40^{\prime}$ & $\begin{array}{l}90 \% \text { recovered. Fairly compacted. Medium- to coarse-grained sand; } 50 \% \text { basalt and } 50 \% \\
\text { felsic; subangular to subrounded; well sorted. Layer of silt and } \mathrm{CaCO}_{3} \text { about } 0.4 \text { in thick } \\
\text { at } 39 \text { '5.5" separating darker (more black and fresh?) material above from more brownish- } \\
\text { reddish (more clayey and weathered?) material below. Color } 10 \mathrm{YR} 5 / 2\end{array}$ \\
\hline $40^{\prime}$ to $41^{\prime}$ & $\begin{array}{l}100 \% \text { recovered. Intact, not disturbed, well compacted. Medium- to coarse-grained sand } \\
\text { with trace of silt; } 50 \% \text { basalt to } 50 \% \text { felsic; subangular to subrounded; well-sorted; color } \\
10 \text { YR } 5 / 2 \text {. }\end{array}$ \\
\hline
\end{tabular}




\begin{tabular}{|c|c|}
\hline $\begin{array}{l}\text { Depth Below Surface } \\
\text { (feet and inches) }\end{array}$ & Description of Core from Borehole C3826 \\
\hline $41^{\prime}$ to $42^{\prime}$ & 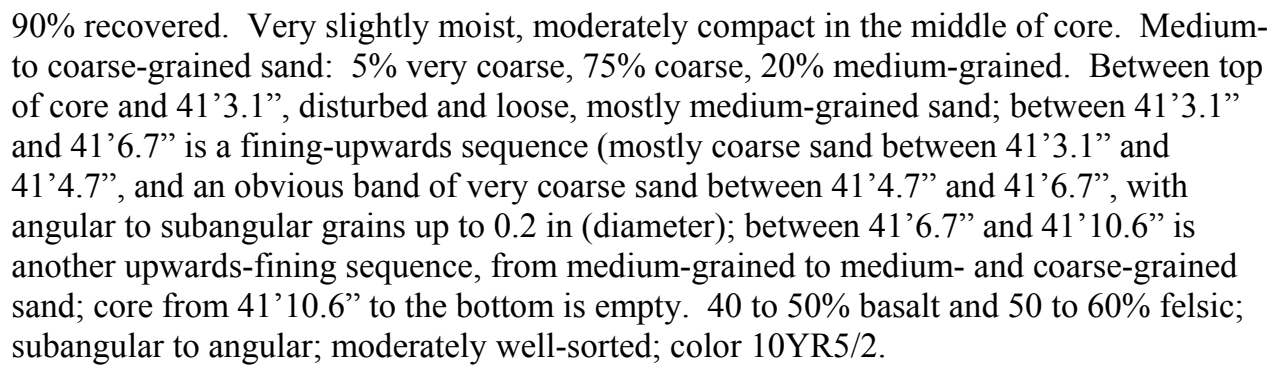 \\
\hline $42^{\prime}$ to $42^{\prime} 6^{\prime \prime}$ & No recovery. \\
\hline $42^{\prime} 6^{\prime \prime}$ to $43^{\prime} 6^{\prime \prime}$ & $\begin{array}{l}60 \% \text { recovered. Dry, loose, disturbed. (Opened previously for LBL oxygen isotope } \\
\text { study.) Medium- to coarse-grained sand: } 30 \% \text { coarse, } 60 \% \text { medium-grained, } 10 \% \text { very } \\
\text { coarse; } 40 \text { to } 50 \% \text { basalt and } 50 \text { to } 60 \% \text { felsic; subangular to angular; fairly well-sorted; } \\
\text { color } 10 \text { YR } 5 / 2 \text {. }\end{array}$ \\
\hline $43^{\prime} 6^{\prime \prime}$ to $44^{\prime} 6^{\prime \prime}$ & $\begin{array}{l}90 \% \text { recovered. Slightly moist, slightly compact. Coarse sand: } 70 \% \text { coarse, } 20 \% \\
\text { medium-grained, } 10 \% \text { very coarse; possible color bands } \sim 1.2 \text { to } 1.6 \text { in wide (upwards- } \\
\text { fining sequences from very coarse to medium-grained sand); distinct pebble layer between } \\
43 \text { ' } 11.7 \text { " and } 44 \text { '0.6", with grains up to } 0.24 \text { in (diameter); } 50 \% \text { basalt and } 50 \% \text { felsic; } \\
\text { mostly angular, with some subangular grains; fairly well-sorted; color } 10 \text { YR } 5 / 2 \text {. }\end{array}$ \\
\hline $44^{\prime} 6$ "' to $47^{\prime}$ & No recovery. \\
\hline $47^{\prime}$ to $48^{\prime}$ & $\begin{array}{l}90 \% \text { recovered. Slightly moist, slightly compact. Medium-to coarse-grained sand: } 15 \% \\
\text { very coarse (mainly in the upper half of core, with grains up to } 0.1 \text { in diameter), } 35 \% \\
\text { coarse, } 50 \% \text { medium-grained; } 40 \text { to } 50 \% \text { basalt and } 50 \text { to } 60 \% \text { felsic; angular to } \\
\text { subangular; fairly sorted; color } 10 \text { YR } 5 / 2 \text {. }\end{array}$ \\
\hline $48^{\prime}$ to $49^{\prime}$ & $\begin{array}{l}95 \% \text { recovered. Compact. Medium-grained sand; } 50 \% \text { basalt and } 50 \% \text { felsic; subangular } \\
\text { to subrounded; well sorted; color } 10 \text { YR } 5 / 2 \text {. Silty } \mathrm{CaCO}_{3} \text {-rich layer from } 48^{\prime} 6.7 \text { " to } \\
48 \text { '8.7". }\end{array}$ \\
\hline $49^{\prime}$ to $50^{\prime}$ & $\begin{array}{l}80 \% \text { recovered. Very slightly moist, very slightly compact, disturbed. (Opened } \\
\text { previously for LBL oxygen isotope study.) Medium- to coarse-grained sand, with grains } \\
\text { up to } 0.16 \text { in (diameter); } 50 \% \text { basalt and } 50 \% \text { felsic; angular to subangular; moderately } \\
\text { sorted; color } 10 \text { YR } 5 / 2 \text {. }\end{array}$ \\
\hline $50^{\prime}$ to $51^{\prime}$ & $\begin{array}{l}\text { 95\% recovered. Compact. Medium-grained sand, with basalt clasts up to } 0.4 \text { in } \\
\text { (diameter); } 50 \% \text { basalt and } 50 \% \text { felsic; subangular to subrounded; well-sorted; color } \\
\text { 10YR5/2. Some color banding, with basalt-rich layers appearing slightly darker. }\end{array}$ \\
\hline $51^{\prime}$ to $58^{\prime}$ & No recovery. \\
\hline $58^{\prime}$ to $59^{\prime}$ & $\begin{array}{l}85 \% \text { recovered. Loose, uncompacted. Medium-grained sand; } 50 \% \text { basalt and } 50 \% \text { felsic; } \\
\text { subangular to subrounded; well sorted; color } 10 \text { YR } 5 / 2 \text {. }\end{array}$ \\
\hline $59^{\prime}$ to $60^{\prime}$ & $\begin{array}{l}90 \% \text { recovered. Loose, uncompacted. Medium-grained sand; } 50 \% \text { basalt and } 50 \% \text { felsic; } \\
\text { subangular to subrounded; well-sorted; color } 10 \text { YR5 } / 2 \text {. }\end{array}$ \\
\hline $60^{\prime}$ to $61^{\prime}$ & $\begin{array}{l}85 \% \text { recovered. Moderately compact. Medium-grained sand; } 50 \% \text { basalt and } 50 \% \text { felsic; } \\
\text { subangular to subrounded; well-sorted; color } 10 \text { YR } 5 / 2 \text {. Color bands and fining-upward } \\
\text { sequences } 0.4 \text { to } 0.8 \text { in thick. }\end{array}$ \\
\hline $61^{\prime}$ to 62 ' & $\begin{array}{l}90 \% \text { recovered. Compact. Medium-grained sand; } 50 \% \text { basalt and } 50 \% \text { felsic; subangular } \\
\text { to subrounded; well-sorted; color } 10 \text { YR } 5 / 2 \text {. Faint color banding. }\end{array}$ \\
\hline $62^{\prime}$ to $664^{\prime} 6^{\prime \prime}$ & Not opened, physical properties testing. \\
\hline
\end{tabular}




\begin{tabular}{|c|c|}
\hline $\begin{array}{l}\text { Depth Below Surface } \\
\text { (feet and inches) }\end{array}$ & Description of Core from Borehole C3826 \\
\hline $64^{\prime} 6 "$ to $65^{\prime} 6 "$ & $\begin{array}{l}80 \% \text { recovered. Slightly moist, slightly compact in middle of core, disturbed. (Opened } \\
\text { previously for LBL oxygen isotope study.) Fine- to medium-grained sand: } 55 \% \text { medium- } \\
\text { grained, } 40 \% \text { fine-grained, } 5 \% \text { coarse; } 35 \text { to } 40 \% \text { basalt and } 60 \text { to } 65 \% \text { felsic; subangular } \\
\text { to angular; well-sorted; color } 10 \mathrm{YR} 5 / 2 \text {. }\end{array}$ \\
\hline $65^{\prime} 6^{\prime \prime}$ to $66^{\prime} 6^{\prime \prime}$ & Not opened, physical properties testing. \\
\hline $66^{\prime} 6 "$ to $67^{\prime} 6^{\prime \prime}$ & $\begin{array}{l}90 \% \text { recovered. Loose, not compact. Medium- to coarse-grained sand; } 50 \% \text { basalt and } \\
50 \% \text { felsic; subangular to subrounded; well sorted; color } 10 \mathrm{YR} 5 / 2 \text {. }\end{array}$ \\
\hline $67^{\prime} 6$ "' to $68^{\prime}$ & No recovery. \\
\hline $68^{\prime}$ to $69^{\prime}$ & $\begin{array}{l}85 \% \text { recovered. Not compact. Medium-grained sand; } 50 \% \text { basalt and } 50 \% \text { felsic; } \\
\text { subangular to subrounded; well-sorted; color } 10 \mathrm{YR} 5 / 2 . \text { Contains } \mathrm{CaCO}_{3} \text {-rich nodules up } \\
\text { to } 0.8 \text { in (diameter) between } 68 \text { '2" and } 68 \text { ' } 4 \text { ". }\end{array}$ \\
\hline $69^{\prime}$ to $70^{\prime}$ & $\begin{array}{l}85 \% \text { recovered. Fairly compact. Between } 69^{\prime} \text { and } 69^{\prime} 44^{\prime \prime} \text {, medium-grained sand in } 0.2 \text {-in- } \\
\text { thick bands; from } 69^{\prime} 4 \text { " to } 70^{\prime} \text { is medium- to coarse-grained sand; } 50 \% \text { basalt and } 50 \% \\
\text { felsic; subangular to subrounded; well-sorted; color } 10 \text { YR5 } 5 / 2 \text {. }\end{array}$ \\
\hline $70^{\prime}$ to $71^{\prime}$ & $\begin{array}{l}90 \% \text { recovered. Dry, loose, uncompacted. Medium- to coarse-grained sand; } 50 \% \text { basalt } \\
\text { and } 50 \% \text { felsic; subangular to subrounded; well-sorted; color } 10 \text { YR } 5 / 2 \text {. }\end{array}$ \\
\hline $71^{\prime}$ to $72^{\prime}$ & $\begin{array}{l}90 \% \text { recovered. Moderately compact. Medium- to coarse-grained sand; } 50 \% \text { basalt and } \\
50 \% \text { felsic; subangular to subrounded; well-sorted; color } 10 \mathrm{YR} 5 / 2 \text {. From } 71 \text { ' } 7 \text { ' to } 71 \text { ' } 9 \text { ' } \\
\text { is a silty layer containing color bands } \sim 0.4 \text { in wide. }\end{array}$ \\
\hline $72^{\prime}$ to $73^{\prime}$ & $\begin{array}{l}85 \% \text { recovered. Dry, loose. Medium- to coarse-grained sand; fine- to medium-grained } \\
\text { sand with silt between } 72^{\prime} 10^{\prime} \text { and } 73 \text { '; } 50 \% \text { basalt and } 50 \% \text { felsic; subangular to } \\
\text { subrounded; well-sorted; color } 10 \text { YR5/2. }\end{array}$ \\
\hline $73^{\prime}$ to $74^{\prime}$ & $\begin{array}{l}90 \% \text { recovered. Moderately compacted. Paleosol? Medium- to fine-grained sand, } \\
\text { cemented with } \mathrm{CaCO}_{3} \text { between } 73 \text { ' and } 73 \text { ' } 4 \text { '; lower part of core is composed of medium- } \\
\text { to coarse-grained sand; } 50 \% \text { basalt and } 50 \% \text { felsic; subangular to subrounded; well-sorted; } \\
\text { color } 10 \text { YR5 } / 2 \text {. }\end{array}$ \\
\hline $74^{\prime}$ to $75^{\prime}$ & $\begin{array}{l}85 \% \text { recovered. Loose, uncompacted. Medium- to coarse-grained sand; } 50 \% \text { basalt and } \\
50 \% \text { felsic; subangular to subrounded; well-sorted; color } 10 \text { YR } 5 / 2 \text {. }\end{array}$ \\
\hline $75^{\prime}$ to $76^{\prime}$ & $\begin{array}{l}95 \% \text { recovered. Fairly compact. Medium- to coarse-grained sand (mostly coarse), with } \\
\text { fining-upwards bands about } 0.8 \text { to } 1.2 \text { in wide; } 50 \% \text { basalt and } 50 \% \text { felsic; subangular to } \\
\text { subrounded; well-sorted; color } 10 \text { YR } 5 / 2 \text {. }\end{array}$ \\
\hline $76^{\prime}$ to $76^{\prime} 6^{\prime \prime}$ & No recovery. \\
\hline $76^{\prime} 6^{\prime \prime}$ to $77^{\prime} 6^{\prime \prime}$ & $\begin{array}{l}80 \% \text { recovered. Uncompacted. Uppermost } 2.5 \text { in is empty; from } 76^{\prime} 8.5^{\prime \prime} \text { to } 77^{\prime} 3 \text { " is } \\
\text { medium- to fine-grained, } \mathrm{CaCO}_{3} \text {-cemented sand, poorly sorted; from } 77^{\prime} 3 \text { " to the bottom } \\
\text { of the core is medium- to coarse-grained sand. All material is fairly well-sorted; } \\
\text { subangular to subrounded; color } 10 \mathrm{YR} 5 / 2 \text {. }\end{array}$ \\
\hline $77^{\prime} 6$ "' to $78^{\prime} 6^{\prime \prime}$ & $\begin{array}{l}80 \% \text { recovered. Dry, loose, disturbed. (Opened previously for LBL oxygen isotope } \\
\text { study.) Medium- to coarse-grained sand: } 65 \% \text { medium- to fine-grained; } 35 \% \text { coarse; } \\
30 \% \text { basalt and } 70 \% \text { felsic; angular to subangular; moderately sorted; color } 10 \text { YR } 5 / 2 \text {. }\end{array}$ \\
\hline $78^{\prime} 6 "$ to $79^{\prime} 6 "$ & $\begin{array}{l}95 \% \text { recovered. Very compact. Medium- to coarse-grained sand, with bands of fining- } \\
\text { upwards sequences } 1.2 \text { to } 1.6 \text { in wide; } 50 \% \text { basalt and } 50 \% \text { felsic; subangular to } \\
\text { subrounded; well-sorted; color } 10 \text { YR } 5 / 2 \text {. }\end{array}$ \\
\hline
\end{tabular}




\begin{tabular}{|c|c|}
\hline $\begin{array}{l}\text { Depth Below Surface } \\
\text { (feet and inches) }\end{array}$ & Description of Core from Borehole C3826 \\
\hline $79^{\prime} 6 "$ to $80^{\prime} 6^{\prime \prime}$ & $\begin{array}{l}95 \% \text { recovered. Well-compacted. Medium- to coarse-grained sand, with subtle fining- } \\
\text { upwards sequences } \sim 0.8 \text { in wide each; } 50 \% \text { basalt and } 50 \% \text { felsic; subangular to } \\
\text { subrounded; well-sorted; color } 10 \text { YR } 5 / 2 \text {. }\end{array}$ \\
\hline $80^{\prime} 6$ " to $96^{\prime}$ & No recovery. \\
\hline $96^{\prime}$ to $97^{\prime}$ & $\begin{array}{l}80 \% \text { recovered. Slightly moist, uncompacted. Medium- to coarse-grained sand (mainly } \\
\text { medium-grained); subangular to subrounded; well-sorted; color } 10 \text { YR } 5 / 2 \text {. }\end{array}$ \\
\hline $97^{\prime}$ to $98^{\prime}$ & $\begin{array}{l}85 \% \text { recovered. Slightly moist, not compact. Medium- to fine-grained sand, with fining- } \\
\text { upward sequences about } 1.2 \text { in wide; } 50 \% \text { basalt and } 50 \% \text { felsic; subangular to } \\
\text { subrounded; well-sorted; color } 10 \text { YR } 5 / 2 \text {. }\end{array}$ \\
\hline $98^{\prime}$ to $99^{\prime}$ & $\begin{array}{l}85-90 \% \text { recovered. Dry, loose, disturbed. (Opened previously for LBL oxygen isotope } \\
\text { study.) Medium- to fine-grained sand: } 50 \% \text { medium, } 50 \% \text { fine; } 40 \% \text { basalt and } 60 \% \\
\text { felsic; angular to subangular; well-sorted; color } 10 \text { YR } 6 / 2 \text {. }\end{array}$ \\
\hline $99^{\prime}$ to $100^{\prime}$ & $\begin{array}{l}\text { 90\% recovered. Moderately compact. Fine- to medium-grained sand between } 99^{\prime} \text { and } \\
\text { 99'8.7'; medium- to coarse-grained sand between } 99^{\prime} 8.7 \text { " to } 99^{\prime} 11.8^{\prime \prime} ; 50 \% \text { basalt and } \\
50 \% \text { felsic; subangular to subrounded; well-sorted; color } 10 \mathrm{YR} 5 / 2 \text {. }\end{array}$ \\
\hline $110^{\prime}$ to $119^{\prime}$ & No recovery. \\
\hline $119^{\prime}$ to $120^{\prime}$ & $\begin{array}{l}90 \% \text { recovered. Not compact. One large fining-upward sequence: medium-grained sand } \\
\text { in lower part, fine-grained sand in uppermost } 2.4 \text { in of core; } 50 \% \text { basalt and } 50 \% \text { felsic; } \\
\text { subangular to subrounded; well-sorted; color } 10 \mathrm{YR} 5 / 2 \text {. }\end{array}$ \\
\hline $120^{\prime}$ to $121^{\prime}$ & $\begin{array}{l}\text { 95- } 100 \% \text { recovered. Medium-grained sand, with } 0.8 \text {-in-wide fining-upwards bands } \\
\text { apparent; } 50 \% \text { basalt and } 50 \% \text { felsic; subangular to subrounded; well-sorted; } 10 \text { YR } 5 / 2 \text {. }\end{array}$ \\
\hline $121^{\prime}$ to $122^{\prime}$ & $\begin{array}{l}85 \% \text { recovered. Dry, slightly compact, disturbed. (Opened previously for LBL oxygen } \\
\text { isotope study.) Fine to very fine sand, thin ( }<0.1 \text { in wide) coherent layers visible between } \\
121 \text { '2.4" and } 121 \text { ' } 8.3 \text { " of very fine-grained sand between darker, basalt-rich medium- } \\
\text { grained layers; } 60 \% \text { fine-grained, } 40 \% \text { medium-grained; very fine-grained loose sand } \\
\text { between } 121 \text { ' } 8.7 \text { " and } 121 \text { ' } 11 \text { "; lowermost } 1 \text { in of core empty; no HCl reaction; } 45 \% \\
\text { basalt and } 55 \% \text { felsic; well-sorted; color } 10 \text { YR } 5 / 2 \text {. }\end{array}$ \\
\hline $122^{\prime}$ to $123^{\prime}$ & $\begin{array}{l}98 \% \text { recovered. Compact. From the top of the core to } 122^{\prime} 0.6^{\prime} \text { ' is fine-grained sand; from } \\
122^{\prime} 0.6 \text { " to } 122^{\prime} 3.5^{\prime} \text { is very coarse sand with color banding; from } 122^{\prime} 3.5^{\prime \prime} \text { is a } 0.08 \text {-in- } \\
\text { wide very fine clay layer, iron-stained at the top; from } 122^{\prime} 3.5^{\prime \prime} \text { to } 122^{\prime} 10.2^{\prime \prime} \text { is the top of } \\
\text { another fining-upwards sequence, medium-grained sand; from } 122^{\prime} 10.2^{\prime \prime} \text { to } 122^{\prime} 11.8^{\prime \prime} \text { is } \\
\text { coarse-grained sand at the bottom of this sequence; } 50 \% \text { basalt and } 50 \% \text { felsic; subangular } \\
\text { to subrounded; well-sorted; color } 10 \text { YR } 5 / 2 \text {. }\end{array}$ \\
\hline $123^{\prime}$ to $149^{\prime}$ & No recovery. \\
\hline $149^{\prime}$ to $150^{\prime}$ & $\begin{array}{l}90 \% \text { recovered. Slightly compact. Medium- to coarse-grained sand, with fining-upwards } \\
\text { sequences about } 0.8 \text { in wide; } 50 \% \text { basalt and } 50 \% \text { felsic; subangular to subrounded; well- } \\
\text { sorted; color } 10 \text { YR5/2. A transition from sand above to more silt below occurs at } \\
149 \text { '10.2". Pebbles about } 0.8 \text { in (diameter) occur at 149'4". }\end{array}$ \\
\hline $150^{\prime}$ to $151^{\prime}$ & $\begin{array}{l}90 \% \text { recovered. Well-compacted. Medium- to coarse-grained sand, some coarse basalt- } \\
\text { rich layers fining upwards in layers } \sim 0.8 \text { in wide; } 50 \% \text { basalt and } 50 \% \text { felsic; subangular } \\
\text { to subrounded; well-sorted. Color } 10 \text { YR } 5 / 2\end{array}$ \\
\hline $151^{\prime}$ to $152^{\prime}$ & $\begin{array}{l}90 \% \text { recovered. Dry, loose, disturbed. (Opened previously for LBL oxygen isotope } \\
\text { study.) Sand: } 70 \% \text { medium-grained, } 30 \% \text { fine-grained, coarse layer with grains up to } \\
0.12 \text { in (diameter) between } 151 ' 5.5^{\prime} \text { and } 151 ' 5.9 " ; 40 \% \text { basalt and } 60 \% \text { felsic; subangular } \\
\text { to subrounded; moderately sorted; color } 10 \mathrm{YR} 6 / 2 \text {. }\end{array}$ \\
\hline
\end{tabular}




\begin{tabular}{|c|c|}
\hline $\begin{array}{l}\text { Depth Below Surface } \\
\text { (feet and inches) }\end{array}$ & Description of Core from Borehole C3826 \\
\hline $152^{\prime}$ to $153^{\prime}$ & $\begin{array}{l}90 \% \text { recovered. Moderately compact. Medium- to fine-grained sand, with subtle fining- } \\
\text { upwards sequences } \sim 3.5 \text { in wide; subangular to subrounded; well-sorted; color } 10 \text { YR5/2. }\end{array}$ \\
\hline $153^{\prime}$ to $163^{\prime} 6^{\prime \prime}$ & No recovery. \\
\hline $163^{\prime} 6^{\prime \prime}$ to $164^{\prime} 6 "$ & $\begin{array}{l}80 \% \text { recovered. Loose, uncompacted, poorly consolidated. Medium- to fine-grained sand, } \\
\text { one fining-upwards sequence; } 50 \% \text { basalt and } 50 \% \text { felsic; subangular to subrounded; well- } \\
\text { sorted; color } 10 \text { YR } 5 / 2 \text {. }\end{array}$ \\
\hline $164^{\prime} 6^{\prime \prime}$ to $165^{\prime} 6 "$ & $\begin{array}{l}95 \text { recovered. Compact. Medium- to fine-grained sand, with subtle upward-fining } \\
\text { sequences } \sim 2 \text { in wide; } 50 \% \text { basalt and } 50 \% \text { felsic; subangular to subrounded; well-sorted; } \\
\text { color } 10 \text { YR5 } / 2 \text {. }\end{array}$ \\
\hline $165^{\prime} 6^{\prime \prime}$ to $166^{\prime} 6^{\prime \prime}$ & $\begin{array}{l}\text { 95\% recovered. Compact. Fine- to medium-grained sand, with fining upward sequences } \\
\sim 3 \text { in wide; } 50 \% \text { basalt and } 50 \% \text { felsic; subangular to subrounded; well-sorted; color } \\
10 \text { YR5/2. }\end{array}$ \\
\hline $166^{\prime} 6^{\prime \prime}$ to $167^{\prime} 6^{\prime \prime}$ & $\begin{array}{l}90 \% \text { recovery. Moderately compact. Medium- to fine-grained sand; with fining upward } \\
\text { sequences } \sim 2 \text { in wide; } 50 \% \text { basalt and } 50 \% \text { felsic; subangular to subrounded; well-sorted. } \\
\text { The zone between } 167 ' 2.5 \text { " and } 167^{\prime} 2.9 \text { " is lined at the top and bottom by brownish silt } \\
\text { stringers }<0.04 \text { in wide. Color } 10 \text { YR } 5 / 2\end{array}$ \\
\hline $167^{\prime} 6 "$ to 168 ' & No recovery. \\
\hline $168^{\prime}$ to $169^{\prime}$ & $\begin{array}{l}85 \% \text { recovered. Compact. Mainly medium- to coarse-grained sand; at } 168^{\prime} 4.7^{\prime \prime} \text { is a } \\
\text { caliche zone } \sim 1.1 \text { in thick showing soft-sediment deformation, with a lobe protruding } 3 \text { to } \\
7.5 \text { in out of the band; at } 168^{\prime} 10.6 \text { " is a } 0.11 \text {-in-wide clay layer at the top of an upward- } \\
\text { fining sequence; fine sand between } 168^{\prime} 10.6 \text { " to } 168^{\prime} 11.8^{\prime \prime} \text {. }\end{array}$ \\
\hline $169^{\prime}$ to $170^{\prime}$ & $\begin{array}{l}98 \% \text { recovered. Well-compacted. Medium- to fine-grained sand, one large fining- } \\
\text { upwards sequence; } 50 \% \text { basalt and } 50 \% \text { felsic; subangular to subrounded; well-sorted; } \\
\text { color } 10 \text { YR } 5 / 2 \text {. Contact between one fining-upwards sequence above and another below } \\
\text { at } 169^{\prime} 10.6 \% \text {. }\end{array}$ \\
\hline $170^{\prime}$ to $171^{\prime}$ & $\begin{array}{l}95 \% \text { recovered. Compact. Medium- to coarse-grained sand, with fining-upward } \\
\text { sequences } 1-2 \text { in wide; } 50 \% \text { basalt and } 50 \% \text { felsic; subangular to subrounded; well-sorted; } \\
\text { color } 10 \text { YR } 5 / 2 \text {. }\end{array}$ \\
\hline $171^{\prime}$ to $172^{\prime} 6^{\prime \prime}$ & Not opened, physical properties testing. \\
\hline $172^{\prime} 6^{\prime \prime}$ to $173^{\prime} 6 "$ & $\begin{array}{l}80 \% \text { recovered. Loose, uncompacted, poorly consolidated. Coarse- to medium-grained } \\
\text { sand, mostly coarse, with pebbles up to } 0.4 \text { in (diameter) in a layer between } 173^{\prime} 0.3^{\prime \prime} \text { to } \\
173 \text { ' } 1.9 \text { "; subangular to subrounded; fairly sorted; color } 10 \text { YR } 5 / 2 \text {. }\end{array}$ \\
\hline $173^{\prime} 6$ "' to $174^{\prime} 6$ ' & $\begin{array}{l}\text { 95\% recovered. Compact. Medium- to coarse-grained sand, with fining upwards } \\
\text { sequences (coarse to fine) each } \sim 0.8 \text { in wide; } 50 \% \text { basalt and } 50 \% \text { felsic; subangular to } \\
\text { subrounded; well-sorted; color } 10 \text { YR } 5 / 2 \text {. }\end{array}$ \\
\hline $174^{\prime} 6^{\prime \prime}$ to $175^{\prime} 6^{\prime \prime}$ & $\begin{array}{l}95 \% \text { recovered. Well-compacted. Medium- to coarse-grained sand, with upward fining } \\
\text { sequences } \sim 0.8 \text { in wide; } 50 \% \text { basalt and } 50 \% \text { felsic; subangular to subrounded; well- } \\
\text { sorted; color } 10 \text { YR } 5 / 2 \text {. }\end{array}$ \\
\hline $175^{\prime} 6^{\prime \prime}$ to $176^{\prime} 6^{\prime \prime}$ & $\begin{array}{l}95 \% \text { recovered. Compact. Medium- to coarse-grained sand, with color bands of upward- } \\
\text { fining sequences about } 1.2 \text { in wide; } 50 \% \text { basalt and } 50 \% \text { felsic; subangular to subrounded; } \\
\text { well-sorted; color } 10 \text { YR } 5 / 2 \text {. }\end{array}$ \\
\hline $176^{\prime} 6^{\prime \prime}$ to $179^{\prime}$ & No recovery. \\
\hline
\end{tabular}




\begin{tabular}{|c|c|}
\hline $\begin{array}{l}\text { Depth Below Surface } \\
\text { (feet and inches) }\end{array}$ & Description of Core from Borehole C3826 \\
\hline $179^{\prime}$ to $180^{\prime}$ & $\begin{array}{l}90 \% \text { recovered. Moist, moderately compact. Medium- to coarse-grained sand, with } \\
\text { fining-upwards sequences } \sim 3.5 \text { in wide; } 50 \% \text { basalt and } 50 \% \text { felsic; subangular to } \\
\text { subrounded; well-sorted; color } 10 \text { YR } 5 / 2 \text {. }\end{array}$ \\
\hline $180^{\prime}$ to $181^{\prime}$ & $\begin{array}{l}95 \% \text { recovered. Well-compacted. Medium- to coarse-grained sand, with upwards-fining } \\
\text { sequences } 2 \text { to } 2.8 \text { in wide; } 50 \% \text { basalt and } 50 \% \text { felsic; subangular to subrounded; well- } \\
\text { sorted; color } 10 \text { YR } 5 / 2 \text {. At } 180 \text { ' } 1.6 \text { " is a layer of clay } ~ 0.04 \text { in wide. }\end{array}$ \\
\hline $181^{\prime}$ to $182^{\prime}$ & $\begin{array}{l}90 \% \text { recovered. Well-compacted. Medium- to coarse-grained sand, containing fining- } \\
\text { upwards sequences mostly } \sim 1 \text { in but up to } 5.5 \text { in wide, with } 0.4 \text {-in-wide sequences within } \\
\text { the thicker bands; } 50 \% \text { basalt and } 50 \% \text { felsic; subangular to subrounded; well-sorted; } \\
\text { color } 10 \text { YR } 5 / 2 \text {. }\end{array}$ \\
\hline $182^{\prime}$ to $183^{\prime}$ & $\begin{array}{l}85 \% \text { recovered. Dry, loose, disturbed. (Opened previously for LBL oxygen isotope } \\
\text { study.) Sand: } 75 \% \text { medium- and fine-grained, } 25 \% \text { coarse; } 40 \% \text { basalt and } 60 \% \text { felsic; } \\
\text { subangular to subrounded; moderately well-sorted; color } 10 \text { YR6 } 6 \text {. }\end{array}$ \\
\hline $183^{\prime}$ to $219^{\prime}$ & No recovery. \\
\hline $219^{\prime}$ to $220^{\prime}$ & $\begin{array}{l}95 \% \text { recovered. Moderately compact. Coarse- to very coarse-grained sand, with a pebbly } \\
\text { zone between } 219^{\prime} 4.7^{\prime \prime} \text { and } 219^{\prime} 6.3^{\prime \prime} \text { containing pebbles mainly of basalt up to } 0.8 \text { in } \\
\text { (diameter); } 60 \% \text { basalt and } 40 \% \text { felsic; subangular to subrounded; well-sorted; color } \\
\text { 10YR } 5 / 2 \text {. }\end{array}$ \\
\hline $220^{\prime}$ to $221^{\prime}$ & $\begin{array}{l}90 \% \text { recovered. Compact. Medium- to very coarse-grained sand, with pebbles up to } 0.4 \\
\text { in (diameter) and fining-upwards sequences } \sim 3 \text { in wide; } 50 \% \text { basalt and } 50 \% \text { felsic; } \\
\text { subangular to subrounded; well-sorted; color } 10 \text { YR } 5 / 2 \text {. }\end{array}$ \\
\hline $221^{\prime}$ to $222^{\prime}$ & $\begin{array}{l}95 \% \text { recovered. Compact. Coarse- to very coarse-grained sand, with clasts up to } 0.8 \text { in } \\
\text { (diameter); coarse basalt-rich bands and upward-fining sequences } 2 \text { to } 2.5 \text { in wide; } 50 \% \\
\text { basalt and } 50 \% \text { felsic; subangular to subrounded; well-sorted; color } 10 \text { YR } 5 / 2 \text {. }\end{array}$ \\
\hline
\end{tabular}




\section{Appendix C}

\section{Description of Core from Borehole C3827}




\section{Appendix C}

\section{Description of Core from Borehole C3827}

\begin{tabular}{|c|c|}
\hline $\begin{array}{l}\text { Depth Below Surface } \\
\text { (feet and inches) }\end{array}$ & Description of Core from Borehole C3827 \\
\hline $0^{\prime}$ to $53.5^{\prime}$ & No recovery. \\
\hline $53^{\prime} 6^{\prime \prime}$ to $54^{\prime} 6^{\prime \prime}$ & $\begin{array}{l}45 \% \text { recovered. Moist, compact. Medium- to coarse-grained sand: } 15 \% \text { very coarse, } \\
30 \% \text { coarse, } 60 \% \text { medium-grained, with grains up to } 0.1 \text { in (diameter); } 50 \% \text { basalt and } \\
50 \% \text { felsic; angular to subangular; moderately well-sorted; color } 10 \mathrm{YR} 5 / 2 \text {. }\end{array}$ \\
\hline $54^{\prime} 6^{\prime \prime}$ to $55^{\prime} 6^{\prime \prime}$ & $\begin{array}{l}95 \% \text { recovered. Moist, compact. Medium- to coarse-grained sand, with upwards-fining } \\
\text { sequences } \sim 0.8 \text { in wide; } 50 \% \text { basalt and } 50 \% \text { felsic, subangular to subrounded; well- } \\
\text { sorted; color } 10 \text { YR } 5 / 2 \text {. }\end{array}$ \\
\hline $55^{\prime} 6^{\prime \prime}$ to $56^{\prime} 6^{\prime \prime}$ & $\begin{array}{l}100 \% \text { recovered. Moist, compact. Medium- to coarse-grained sand with crude, subtle } \\
\text { upwards-fining sequences } \sim 2 \text { in wide; medium- to coarse-grained sand between } 56^{\prime} 5.4 \text { " } \\
\text { and } 56 \text { ' } 5.8^{\prime \prime} ; 50 \% \text { basalt and } 50 \% \text { felsic; subangular to subrounded; well-sorted; color } \\
10 \text { YR5/2. A fine-grained sand to silt lens between } 566^{\prime} 4.2 \text { " and } 566^{\prime} 5.4 \text { " has a } 0.04 \text { in layer } \\
\text { of clay at the bottom and top. }\end{array}$ \\
\hline $56^{\prime} 6^{\prime \prime}$ to $57^{\prime} 6^{\prime \prime}$ & $\begin{array}{l}93 \% \text { recovered. Moist, compact. Coarse sand from top of core to } 56 \text { ' } 7.8 \text { "; very coarse } \\
\text { sand between } 56 \text { '7.8" and } 56 \text { ' } 11.5^{\prime \prime} \text { medium-grained sand between } 56 \text { ' } 11.5 \text { " and } 577^{\prime} 0.3 \text { ", } \\
\text { a dark band containing } \sim 60 \% \text { basalt; continued coarsening downward, from } 57^{\prime} 0.3 \text { " to } \\
57 \text { '5.8"; } 50 \% \text { basalt and } 50 \% \text { felsic; subangular to subrounded; well-sorted; color } \\
\text { 10YR5/2. }\end{array}$ \\
\hline $57^{\prime} 6$ "' to $58^{\prime}$ & No recovery. \\
\hline $58^{\prime}$ to $59^{\prime}$ & $\begin{array}{l}95 \% \text { recovered. Moist, moderately compact. Medium- to coarse-grained sand; } 50 \% \\
\text { basalt and } 50 \% \text { felsic; subangular to subrounded; well-sorted; color } 10 \mathrm{YR} 5 / 2 \text {. }\end{array}$ \\
\hline $59^{\prime}$ to $60^{\prime}$ & $\begin{array}{l}96 \% \text { recovered. Moist, moderately compact. Medium- to coarse-grained sand; } 50 \% \\
\text { basalt and } 50 \% \text { felsic; subangular to subrounded; well-sorted; color } 10 \text { YR5 } 2 \text {. }\end{array}$ \\
\hline $60^{\prime}$ to $61^{\prime}$ & $\begin{array}{l}99 \% \text { recovered. Moist, compact. Medium-grained sand from the top of core to } 60 \text { ' } 6.7 \text { ', } \\
\text { with color bands } 0.8 \text { to } 1.2 \text { in wide; coarse to very coarse sand between } 60^{\prime} 6.7 \text { " and } \\
60 \text { ' } 9.4 \text { ", with pebbles up to } 0.8 \text { in (diameter) at } 60^{\prime} 9.4 \text { "; coarse sand between } 600^{\prime} 9.4 \text { " and } \\
\text { bottom of core; } 50 \% \text { basalt and } 50 \% \text { felsic; subangular to subrounded; well-sorted; color } \\
10 \text { YR5/2. }\end{array}$ \\
\hline $61^{\prime}$ to $62^{\prime}$ & $\begin{array}{l}95 \% \text { recovered. Slightly moist, compact. Medium- to coarse-grained sand, with upwards- } \\
\text { fining sequences (very coarse to medium-grained sand) } \sim 2.8 \text { in wide and pebbles up to } 0.6 \\
\text { in (diameter); } 50 \% \text { basalt and } 50 \% \text { felsic; subangular to subrounded; well-sorted; color } \\
10 \text { YR5 } / 2 \text {. }\end{array}$ \\
\hline $62^{\prime}$ to $62^{\prime} 6^{\prime \prime}$ & No recovery. \\
\hline $62^{\prime} 66^{\prime \prime}$ to $63^{\prime} 6{ }^{\prime \prime}$ & $\begin{array}{l}95 \% \text { recovered. Compact. Moist, medium-grained sand from top of core to } 62^{\prime} 8^{\prime \prime} ; \\
\text { bioturbated, calcareous paleosol, medium- to fine-grained between } 62^{\prime} 8^{\prime \prime} \text { and } 62^{\prime} 11.9^{\prime \prime} \text {; } \\
\text { dry, coarse-grained sand with disseminated } \mathrm{CaCO}_{3} \text { and pebbles up to } 0.2 \text { in (diameter) } \\
\text { between } 62^{\prime} 11.9^{\prime \prime} \text { and } 63^{\prime} 5^{\prime} \text {. Color } 10 \mathrm{YR} 5 / 2 \text {. }\end{array}$ \\
\hline
\end{tabular}




\begin{tabular}{|c|c|}
\hline $\begin{array}{l}\text { Depth Below Surface } \\
\text { (feet and inches) }\end{array}$ & Description of Core from Borehole C3827 \\
\hline $63^{\prime} 6 "$ to $65^{\prime} 6 "$ & Not opened, physical properties testing. \\
\hline $65^{\prime} 6^{\prime \prime}$ to $66^{\prime} 6^{\prime \prime}$ & $\begin{array}{l}92 \% \text { recovered. Moist, compact. Very coarse-grained sand from the top of core to } \\
65 \text { '11.5"; coarse sand between } 65^{\prime} 11.5 \text { " and the bottom of core; subangular to } \\
\text { subrounded; well-sorted; color } 10 \text { YR5/2. }\end{array}$ \\
\hline $66^{\prime} 6^{\prime \prime}$ to $76^{\prime}$ & No recovery. \\
\hline $76^{\prime}$ to $77^{\prime}$ & $\begin{array}{l}100 \text { recovered. Moist, slightly compact (more compact near the bottom of core). } \\
\text { Medium- to coarse-grained sand, with faint color banding } 0.8 \text { to } 1.2 \text { in wide in the bottom } \\
\text { half of core; } 50 \% \text { basalt and } 50 \% \text { felsic; subangular to subrounded; well-sorted; color } \\
10 \text { YR } 5 / 2 \text {. }\end{array}$ \\
\hline $77^{\prime}$ to $78^{\prime}$ & $\begin{array}{l}100 \% \text { recovered. Moist, compact. Medium- to coarse-grained sand, with upwards-fining } \\
\text { sequences } 1.2 \text { to } 2.8 \text { in wide; a prominent upwards-fining sequence between } 77^{\prime} 7.9^{\prime \prime} \text { and } \\
77^{\prime} 11.8 \text { "; } 50 \% \text { basalt and } 50 \% \text { felsic; subangular to subrounded; well-sorted; color } \\
10 \text { YR } 5 / 2 \text {. }\end{array}$ \\
\hline $78^{\prime}$ to $79^{\prime}$ & $\begin{array}{l}100 \% \text { recovered. Moist, compact. From the top of core to } 78^{\prime} 3.5^{\prime \prime} \text {, coarse to very coarse } \\
\text { sand at the top to medium-grained sand at the bottom, with color bands } \sim 0.4 \text { in wide; from } \\
78^{\prime} 3.5^{\prime} \text { to } 78^{\prime} 5.3 \text { ", a fine sand-silt band; from } 78^{\prime} 5.3^{\prime \prime} \text { to } 78^{\prime} 9.1 \text { ", coarse to very coarse } \\
\text { sand; from } 78 \text { '9.1"to the bottom of core, coarse sand at the top to medium-grained sand at } \\
\text { the bottom, with a band of fine material at } 78^{\prime} 9.4 " ; 50 \% \text { basalt and } 50 \% \text { felsic; subangular } \\
\text { to subrounded; well-sorted; color } 10 \text { YR } 5 / 2 \text {. }\end{array}$ \\
\hline $79^{\prime}$ to $80^{\prime}$ & 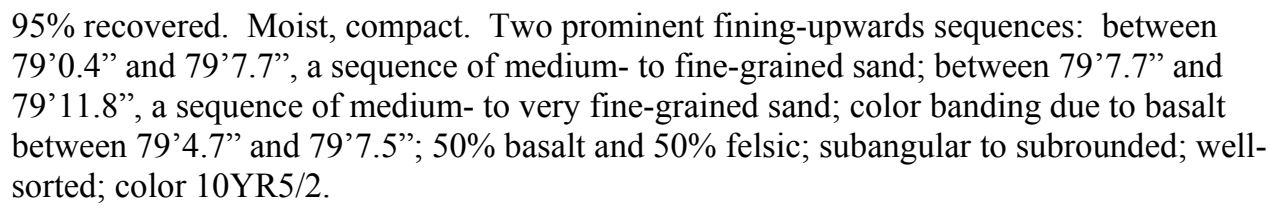 \\
\hline $80^{\prime}$ to $98^{\prime}$ & No recovery. \\
\hline $98^{\prime}$ to $99^{\prime}$ & $\begin{array}{l}95 \% \text { recovered. Moist, coarse to very coarse sand from the top of core to } 987^{\prime} 7^{\prime} ; \text { drier, } \\
\text { medium- to coarse-grained sand fining upwards between } 98 \text { ' } 7 \text { " and the bottom of core; } \\
50 \% \text { basalt and } 50 \% \text { felsic; subangular to subrounded; well-sorted; color } 10 \text { YR } 5 / 2 \text {. }\end{array}$ \\
\hline 99' to $100^{\prime}$ & $\begin{array}{l}100 \% \text { recovered. Slightly moist, compact. Medium-grained sand; } 50 \% \text { basalt and } 50 \% \\
\text { felsic; subangular to subrounded; well-sorted; color } 10 \text { YR } 5 / 2 \text {. }\end{array}$ \\
\hline $100^{\prime}$ to $101^{\prime}$ & $\begin{array}{l}100 \% \text { recovered. Slightly moist, compact. Fine- to coarse-grained sand, in one large } \\
\text { fining-upwards sequence; } 50 \% \text { basalt and } 50 \% \text { felsic; subangular to subrounded; well- } \\
\text { sorted; color } 10 \text { YR } 5 / 2 \text {. }\end{array}$ \\
\hline $101^{\prime}$ to $102^{\prime}$ & $\begin{array}{l}95 \% \text { recovered. Slightly moist, well-compacted. Medium-to coarse-grained sand, with a } \\
\text { band of finer-grained sand between } 101^{\prime} 7.5^{\prime \prime} \text { and } 101^{\prime} 8.7 " ; 50 \% \text { basalt and } 50 \% \text { felsic; } \\
\text { subangular to subrounded; well-sorted; color } 10 \text { YR } 5 / 2 \text {. }\end{array}$ \\
\hline $102^{\prime}$ to $119^{\prime}$ & No recovery. \\
\hline $110^{\prime}$ to $120^{\prime}$ & $\begin{array}{l}100 \% \text { recovered. Moist, compact. Medium- to coarse-grained sand, with the uppermost } \\
2.8 \text { in of core slightly more coarse, and containing color bands } 1.5 \text { to } 2 \text { in wide, probably } \\
\text { upwards-fining; } 50 \% \text { basalt and } 50 \% \text { felsic; subangular to subrounded; well-sorted; color } \\
10 \text { YR5/2. }\end{array}$ \\
\hline $120^{\prime}$ to $121^{\prime}$ & $\begin{array}{l}100 \% \text { recovered. Slightly moist, compact. Medium- to coarse-grained sand, with color } \\
\text { bands } \sim 0.8 \text { in wide and subtle upwards-fining sequences(?); } 50 \% \text { basalt and } 50 \% \text { felsic; } \\
\text { subangular to subrounded; well-sorted; color } 10 \text { YR } 5 / 2 \text {. }\end{array}$ \\
\hline
\end{tabular}




\begin{tabular}{|c|c|}
\hline $\begin{array}{l}\text { Depth Below Surface } \\
\text { (feet and inches) }\end{array}$ & Description of Core from Borehole C3827 \\
\hline $121^{\prime}$ to $122^{\prime}$ & $\begin{array}{l}100 \% \text { recovered. Slightly moist, compact. Medium- to coarse-grained sand, with color } \\
\text { bands } \sim 0.8 \text { in wide and subtle upwards-fining sequences(?); } 50 \% \text { basalt and } 50 \% \text { felsic; } \\
\text { subangular to subrounded; well-sorted; color } 10 \text { YR } 5 / 2 \text {. }\end{array}$ \\
\hline $122^{\prime}$ to $123^{\prime}$ & $\begin{array}{l}90 \% \text { recovered. Slightly moist, compact. Medium- to coarse-grained sand, with color } \\
\text { bands } \sim 0.8 \text { in wide and subtle upwards-fining sequences(?); } 50 \% \text { basalt and } 50 \% \text { felsic; } \\
\text { subangular to subrounded; well-sorted; color } 10 \text { YR } 5 / 2 \text {. }\end{array}$ \\
\hline $123^{\prime}$ to $149^{\prime}$ & No recovery. \\
\hline $149^{\prime}$ to $150^{\prime}$ & $\begin{array}{l}93 \% \text { recovered. Dry, slightly compact, fairly loose. Medium- to coarse-grained sand; } \\
50 \% \text { basalt and } 50 \% \text { felsic; subangular to subrounded; well-sorted; color } 10 \text { YR5 } / 2 \text {. }\end{array}$ \\
\hline $150^{\prime}$ to $151^{\prime}$ & $\begin{array}{l}90 \% \text { recovered. Dry, moderately compact. Medium-grained sand, with grains up to } 0.2 \text { in } \\
\text { (diameter); subangular to subrounded; well-sorted; color } 10 \text { YR } 5 / 2 \text {. }\end{array}$ \\
\hline $151^{\prime}$ to $152^{\prime}$ & $\begin{array}{l}90 \% \text { recovered. Dry, moderately compact. Medium- to fine-grained sand, with upwards- } \\
\text { fining bands } \sim 1.2 \text { in wide; } 50 \% \text { basalt and } 50 \% \text { felsic; subangular to subrounded; well- } \\
\text { sorted; color } 10 \text { YR } 5 / 2 \text {. }\end{array}$ \\
\hline $152^{\prime}$ to $153^{\prime}$ & $\begin{array}{l}90 \% \text { recovered. Dry, moderately compact. Medium- to fine-grained sand; } 50 \% \text { basalt and } \\
50 \% \text { felsic; subangular to subrounded; well-sorted; color } 10 \mathrm{YR} 5 / 2 \text {. }\end{array}$ \\
\hline $153^{\prime}$ to $153^{\prime} 6^{\prime \prime}$ & No recovery. \\
\hline $153^{\prime} 6$ " to $154^{\prime} 6$ '" & $\begin{array}{l}95 \% \text { recovered. Moderately moist, uncompacted. Medium- to coarse-grained sand; } 50 \% \\
\text { basalt and 50\% felsic; subangular to subrounded; well-sorted; color } 10 \text { YR5/2. }\end{array}$ \\
\hline $154^{\prime} 6$ " to $155^{\prime} 6^{\prime \prime}$ & $\begin{array}{l}95 \% \text { recovered. Dry, moderately compact. Medium- to coarse-grained sand from the top } \\
\text { of core to } 154 \text { ' } 11.5 \text { "; from } 154 \text { ' } 11.5 \text { " to the bottom of core, very coarse sand with pebbles } \\
\text { up to } 1 \text { in (diameter); most pebbles are found in a layer at } 1555^{\prime} 3.8 \text { "; } 50 \% \text { basalt and } 50 \% \\
\text { felsic; subangular to subrounded; well-sorted; color } 10 \text { YR } 5 / 2 \text {. }\end{array}$ \\
\hline $155^{\prime} 6^{\prime \prime}$ to $156^{\prime} 6^{\prime \prime}$ & $\begin{array}{l}95 \% \text { recovered. Dry, slightly compact. Coarse sand with pebbles up to } 0.4 \text { in (diameter) } \\
\text { from the top of core to } 155^{\prime} 11.5 \text { "; medium- to coarse-grained sand between } 155^{\prime} 11.5 \text { " } \\
\text { and } 156 \text { '5.8"; pebbles up to } 1.6 \text { in (diameter) at } 156{ }^{\prime} 3.8 \text { "; } 50 \% \text { basalt and } 50 \% \text { felsic; } \\
\text { subangular to subrounded; well-sorted; color } 10 \text { YR } 5 / 2 \text {. }\end{array}$ \\
\hline $156^{\prime} 6^{\prime \prime}$ to $157^{\prime} 6^{\prime \prime}$ & $\begin{array}{l}95 \% \text { recovered. Dry, slightly compact. Fine- to medium-grained sand, with fining- } \\
\text { upwards sequences } \sim 1.2 \text { in side; } 50 \% \text { basalt and } 50 \% \text { felsic; subangular to subrounded; } \\
\text { well-sorted; color } 10 \text { YR } 5 / 2 \text {. }\end{array}$ \\
\hline $157^{\prime} 6$ ' to $158^{\prime}$ & No recovery. \\
\hline $158^{\prime}$ to $159^{\prime}$ & $\begin{array}{l}95 \% \text { recovered. Dry, slightly compact. Uppermost } 1.6 \text { in of core is empty; fine-grained, } \\
\text { compact paleosol cemented with CaCO3 between } 158^{\prime} 1.6^{\prime} \text { to to } 158^{\prime} 5.1 \text { "; less cemented } \\
\text { medium- to fine-grained sand between } 158^{\prime} 5.1 \text { " and } 158^{\prime} 8.7^{\prime} ; \text { from } 158^{\prime} 8.7^{\prime} \text { to the } \\
\text { bottom of core, slightly cemented, compact medium- to fine-grained sand; } 50 \% \text { basalt and } \\
50 \% \text { felsic; subangular to subrounded; well-sorted; color } 10 \text { YR } 5 / 2 \text {. }\end{array}$ \\
\hline $159^{\prime}$ to $160^{\prime}$ & $\begin{array}{l}98 \% \text { recovered. Moist, compact. Medium- to coarse-grained sand with upwards-fining } \\
\text { sequences } 0.8 \text { to } 1.2 \text { in wide; } 50 \% \text { basalt and } 50 \% \text { felsic; subangular to subrounded; well- } \\
\text { sorted; color } 10 \text { YR } 5 / 2 \text {. }\end{array}$ \\
\hline $160^{\prime}$ to $161^{\prime}$ & $\begin{array}{l}97 \% \text { recovered. Dry, moderately compact. Medium- to fine-grained sand, with fining- } \\
\text { upwards sequences } \sim 0.8 \text { in wide; } 50 \% \text { basalt and } 50 \% \text { felsic; subangular to subrounded; } \\
\text { well-sorted; color } 10 \text { YR } 5 / 2 \text {. }\end{array}$ \\
\hline
\end{tabular}




\begin{tabular}{|c|c|}
\hline $\begin{array}{l}\text { Depth Below Surface } \\
\text { (feet and inches) }\end{array}$ & Description of Core from Borehole C3827 \\
\hline $161^{\prime}$ to $162^{\prime}$ & $\begin{array}{l}96 \% \text { recovered. Dry, slightly compact. Medium- to fine-grained sand, with fining- } \\
\text { upwards sequences (possibly fining-downwards?) } 0.8 \text { to } 1.2 \text { in wide; } 50 \% \text { basalt and } 50 \% \\
\text { felsic; subangular to subrounded; well-sorted; color } 10 \text { YR5/2. }\end{array}$ \\
\hline $162^{\prime}$ to $162{ }^{\prime} 6^{\prime \prime}$ & No recovery. \\
\hline $162 ' 6 "$ " to $163^{\prime} 6 "$ & 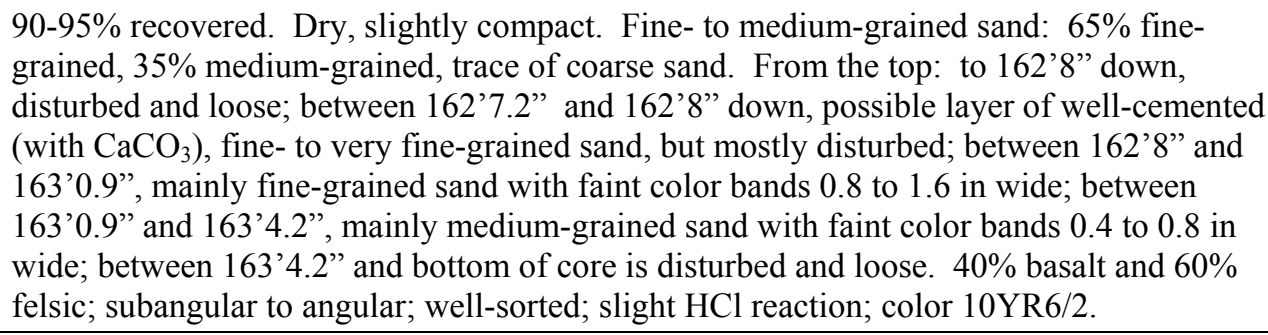 \\
\hline 163 '6" to $164 ' 6 "$ & Not opened, physical properties testing. \\
\hline 164 '6" to $165^{\prime} 6 "$ & $\begin{array}{l}95 \% \text { recovered. Dry, loose, uncompacted. Medium- to fine-grained sand; } 50 \% \text { basalt and } \\
50 \% \text { felsic; subangular to subrounded; well-sorted; color } 10 \mathrm{YR} 5 / 2 \text {. }\end{array}$ \\
\hline $165^{\prime} 6^{\prime \prime}$ to $166^{\prime} 6^{\prime \prime}$ & $\begin{array}{l}90 \% \text { recovered. Dry, moderately compact. Fine-to medium-grained sand, with upwards- } \\
\text { fining sequences } \sim 0.8 \text { in wide; } 50 \% \text { basalt and } 50 \% \text { felsic; subangular to subrounded; } \\
\text { well-sorted; color } 10 \text { YR } 5 / 2 \text {. }\end{array}$ \\
\hline $166^{\prime} 6 "$ to 179 ' & No recovery. \\
\hline $179^{\prime}$ to 180 & $\begin{array}{l}95 \% \text { recovered. Dry, loose. Uppermost } 1.2 \text { in of core empty; coarse to very coarse sand } \\
\text { between } 179^{\prime} 1.2^{\prime \prime} \text { and } 179^{\prime} 2.8 \text { "; very coarse sand between } 179^{\prime} 2.8^{\prime \prime} \text { and } 179^{\prime} 6.5^{\prime \prime} ; \\
\text { medium- to coarse-grained sand from } 179^{\prime} 6.5^{\prime} \text { to bottom of core; pebbles up to } 0.8 \text { in } \\
\text { (diameter) in upper } 6.5 \text { in of core; } 50 \% \text { basalt and } 50 \% \text { felsic; subangular to subrounded; } \\
\text { well-sorted; color } 10 \text { YR } 5 / 2 \text {. }\end{array}$ \\
\hline $180^{\prime}$ to $181^{\prime}$ & $\begin{array}{l}98 \% \text { recovered. Dry, compact. Medium- to coarse-grained sand, with color bands } \\
\text { (upwards-fining sequences) } 0.8 \text { to } 1.2 \text { in wide; } 50 \% \text { basalt and } 50 \% \text { felsic; subangular to } \\
\text { subrounded; well-sorted; color } 10 \text { YR } 5 / 2 \text {. }\end{array}$ \\
\hline $181^{\prime}$ to $182^{\prime}$ & $\begin{array}{l}96 \% \text { recovered. Dry, well-compacted. Medium- to coarse-grained sand, with color bands } \\
\text { (upwards-fining sequences) } 0.8 \text { to } 1.2 \text { in wide; } 50 \% \text { basalt and } 50 \% \text { felsic; subangular to } \\
\text { subrounded; well-sorted; color } 10 \text { YR } 5 / 2 \text {. }\end{array}$ \\
\hline $182^{\prime}$ to $183^{\prime}$ & $\begin{array}{l}99 \% \text { recovered. Dry, well-compacted. Medium- to coarse-grained sand, with color bands } \\
\text { (upwards-fining sequences) } 0.8 \text { to } 1.2 \text { in wide; } 50 \% \text { basalt and } 50 \% \text { felsic; subangular to } \\
\text { subrounded; well-sorted; color 10YR5/2. }\end{array}$ \\
\hline $183^{\prime}$ to $219^{\prime}$ & No recovery. \\
\hline $219^{\prime}$ to $220^{\prime}$ & $\begin{array}{l}75 \% \text { recovered. Dry, not compact. Coarse to very coarse sand, with pebbles, mainly of } \\
\text { basalt, up to } 0.8 \text { in (diameter); } 50 \% \text { basalt and } 50 \% \text { felsic; subangular to subrounded; } \\
\text { well-sorted; color 10YR } 5 / 2 \text {. }\end{array}$ \\
\hline $220^{\prime}$ to $221^{\prime}$ & $\begin{array}{l}96 \% \text { recovered. Dry, compact. Uppermost } 1.2 \text { in of core is empty; between } 220 \text { ' } 1.2 \text { " to } \\
220 \text { ' } 6.3 \text { ", very coarse sand; between } 220 \text { ' } 6.3 \text { " and } 220 \text { ' } 7.1 \text { ", medium- to coarse-grained } \\
\text { sand; between } 220 \text { ' } 7.1 \text { " and bottom of core is coarse and very coarse sand; pebbles mostly } \\
0.8 \text { in (diameter) but up to } 0.8 \text { in; subtle color bands (fining-upwards sequences) } \sim 1.2 \text { in } \\
\text { wide throughout core; } 50 \% \text { basalt and } 50 \% \text { felsic; subangular to subrounded; well-sorted; } \\
\text { color } 10 \text { YR5/2. }\end{array}$ \\
\hline $221^{\prime}$ to $222^{\prime}$ & $95-100 \%$ recovered-not opened. \\
\hline
\end{tabular}




\begin{tabular}{||c|c||}
\hline $\begin{array}{c}\text { Depth Below Surface } \\
\text { (feet and inches) }\end{array}$ & \multicolumn{1}{|c||}{ Description of Core from Borehole C3827 } \\
\hline \hline $222^{\prime}$ to 223' & $\begin{array}{l}\text { 85\% recovered. Dry, moderately compact (especially in lower part of core). Uppermost } \\
0.8 \text { in of core is empty; between 222'0.8" and 222'6.3”, very coarse sand, with pebbles up } \\
\text { to } 0.8 \text { in (diameter), containing a 0.2-in-wide medium-grained sand layer at 222'5.1'; } \\
\text { between 222'6.3" and 222'10.6”, medium- to coarse-grained sand; core is empty between } \\
222 ' 10.6 \text { " and the bottom; 50\% basalt and 50\% felsic; subangular to subrounded; well- } \\
\text { sorted; color 10YR5/2. }\end{array}$ \\
\hline
\end{tabular}


Appendix D

Description of Core from Borehole C3828 


\section{Appendix D}

\section{Description of Core from Borehole C3828}

\begin{tabular}{|c|c|}
\hline $\begin{array}{l}\text { Depth Below Surface } \\
\text { (feet and inches) }\end{array}$ & Description of Core from Borehole C 3828 \\
\hline 0' to 53'6" & No recovery. \\
\hline $53^{\prime} 6 "$ to $55^{\prime} 6^{\prime \prime}$ & $\begin{array}{l}99 \% \text { recovered. Moist, compact. Medium- to coarse-grained sand, with a } 0.2 \text {-in-wide silt } \\
\text { band at } 54 \text { '0.7" and subtle upwards-fining sequences } \sim 1.2 \text { in wide; } 50 \% \text { basalt and } 50 \% \\
\text { felsic; subangular to subrounded; well-sorted; color } 10 \text { YR } 5 / 2 \text {. }\end{array}$ \\
\hline $55^{\prime} 6 "$ to $57^{\prime} 6 "$ & $\begin{array}{l}90 \% \text { recovered. Moist, compact. Medium- to coarse-grained sand; } 50 \% \text { basalt and } 50 \% \\
\text { felsic; subangular to subrounded; well-sorted; color } 10 \text { YR } 5 / 2 \text {. }\end{array}$ \\
\hline $57^{\prime} 6$ '" to $58^{\prime}$ & No recovery. \\
\hline $58^{\prime}$ to 60 ' & $\begin{array}{l}95 \% \text { recovered. Moist, compact. Medium- to coarse-grained sand; } 50 \% \text { basalt and } 50 \% \\
\text { felsic; subangular to subrounded; well-sorted; color } 10 \mathrm{YR} 5 / 2 \text {. }\end{array}$ \\
\hline $60^{\prime}$ to $62^{\prime} 6^{\prime \prime}$ & No recovery. \\
\hline $62{ }^{\prime} 6 "$ to $64^{\prime} 6 "$ & $\begin{array}{l}97 \% \text { recovered. Moist, compact. Medium- to coarse-grained sand, with subtle upwards- } \\
\text { fining sequences; } 50 \% \text { basalt and } 50 \% \text { felsic; well-sorted; color } 10 \text { YR } 5 / 2 \text {. }\end{array}$ \\
\hline $64^{\prime} 6 "$ to $65^{\prime} 6^{\prime \prime}$ & $\begin{array}{l}97 \% \text { recovered. Moist, compact. Medium- to coarse-grained sand, with upwards-fining } \\
\text { sequences } \sim 1.1 \text { in wide, scattered pebbles up to } 0.8 \text { in (diameter) and a silt layer } 0.11 \text { in } \\
\text { wide at } 65{ }^{\prime} 4^{\prime \prime} ; 50 \% \text { basalt and } 50 \% \text { felsic; subangular to subrounded; color } 10 Y R 5 / 2 \text {. }\end{array}$ \\
\hline $65^{\prime} 6^{\prime \prime}$ to $153^{\prime}$ & No recovery. \\
\hline $153^{\prime}$ to $155^{\prime}$ & $\begin{array}{l}60 \% \text { recovered. Moist. Empty between } 153 \text { ' and } 153^{\prime} 9.4 \text { "; silt layer from } 153 \text { '2" to } \\
153 \text { ' } 2.4 \text { " separating medium- to fine-grained sand below from medium- to coarse-grained } \\
\text { sand above; silt lens } \sim 0.4 \text { in wide at } 153 \text { ' } 11 \text { '. Medium- to coarse-grained sand' } 50 \% \text { basalt } \\
\text { and } 50 \% \text { felsic; subangular to subrounded; well-sorted; color } 10 \text { YR } 5 / 2 \text {. }\end{array}$ \\
\hline $155^{\prime}$ to $158^{\prime}$ & $\begin{array}{l}\text { Not opened, physical properties testing. Sample interval } 155^{\prime} 6 \text { " to } 157^{\prime} 6 \text { " is compact and } \\
\text { contains a clastic dike, } 1.2 \text { " wide and composed of very fine to fine-grained sand, cutting } \\
\text { through medium-grained sand that is } 20 \% \text { basaltic and } 80 \% \text { felsic (light-colored) on one } \\
\text { side and } 50 \% \text { basaltic and } 50 \% \text { felsic (dark-colored) on the other side of the dike. }\end{array}$ \\
\hline $158^{\prime}$ to $160^{\prime}$ & 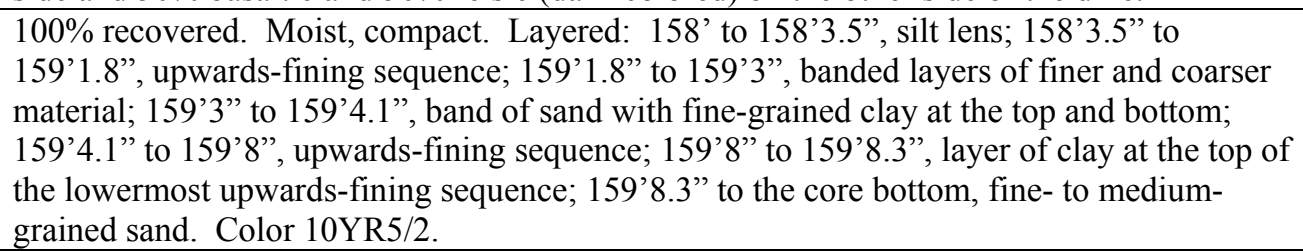 \\
\hline $160^{\prime}$ to $162^{\prime}$ & $\begin{array}{l}96 \% \text { recovered. Moist, compact. Medium- to coarse-grained sand, with a possible } \\
\text { paleosol between } 161 \text { '5.7” and } 161 ' 9.7 ” 50 \% \text { basalt and } 50 \% \text { felsic; subangular to } \\
\text { subrounded; well-sorted; color } 10 \text { YR } 5 / 2 \text {. }\end{array}$ \\
\hline $162^{\prime}$ to $162^{\prime} 6^{\prime \prime}$ & No recovery. \\
\hline $162^{\prime} 6 "$ " to $164 ' 6 "$ & $\begin{array}{l}100 \% \text { recovered. Moist, compact. Medium-grained sand, with crude banding } \sim 0.8 \text { in } \\
\text { wide; } 50 \% \text { basalt and } 50 \% \text { felsic; subangular to subrounded; well-sorted; color } 10 \text { YR } 5 / 2 \text {. }\end{array}$ \\
\hline $164^{\prime} 6^{\prime \prime}$ to $166^{\prime} 6^{\prime \prime}$ & $\begin{array}{l}96 \% \text { recovered. Moist, compact. Medium- to fine-grained sand, with subtle upwards- } \\
\text { fining sequences; } 50 \% \text { basalt and } 50 \% \text { felsic; subangular to subrounded; well-sorted; color } \\
10 \text { YR5/2. }\end{array}$ \\
\hline
\end{tabular}

D. 1 


\section{Appendix E}

Summary of Spectral Gamma Logging 2002 Immobilized Low Activity Waste Well Installation 


\title{
Appendix E
}

\section{Summary of Spectral Gamma Logging 2002 Immobilized Low Activity Waste Well Installation}

\author{
RG McCain \\ Stoller - Grand Junction Team
}

\section{E.1 Introduction}

High-resolution spectral gamma logging was performed in three boreholes (299-E17-22, 299-E17-23, and 299-E17-25) in the vicinity of the proposed site for the Immobilized Low Activity Waste (ILAW) disposal site. High-resolution spectral gamma logging provides a total gamma log, as well the distribution of naturally occurring radionuclides $\left({ }^{40} \mathrm{~K},{ }^{238} \mathrm{U}\right.$, and $\left.{ }^{232} \mathrm{Th}\right)$. This information provides some indication as to the nature of the surrounding sediments and is useful for stratigraphic correlation. In addition, any man-made gamma-emitting radionuclides $\left({ }^{137} \mathrm{Cs},{ }^{60} \mathrm{Co},{ }^{152 / 154} \mathrm{Eu}^{235 / 238} \mathrm{U}\right)$ that may be present can be identified and quantified.

\section{E.2 Methods}

The ILAW boreholes were logged by the spectral gamma logging system (SGLS), which uses a cryogenically cooled high purity germanium (HPGe) detector with an intrinsic efficiency of approximately 35 percent.

With the SGLS, gamma energy spectra are collected in "move-stop-acquire" mode where the detector sonde is held stationary for each measurement and then moved a specified depth increment to the next measurement point. For the ILAW boreholes, a depth increment of $1 \mathrm{ft}$ was used. System gain is adjusted as necessary to maintain a consistent channel relationship for a marker peak (typically the ${ }^{40} \mathrm{~K}$ peak at $1461 \mathrm{keV}$ ). Typical count times were 200 seconds. Individual gamma energy spectra are recorded using 4096 channels, where channel number is related to gamma energy level. Pre-run and post-run verification measurements are made at the beginning and end of each logging day to provide the channelto-energy calibration and to assess system performance.

Evaluation of gamma energy spectra provides identification and quantification of naturally occurring and man-made radionuclides on the basis of characteristic energy emissions associated with their decay. Only gamma rays of sufficient energy to penetrate the steel borehole casing and sonde housing can be detected by the SGLS. Radionuclides that emit one or more gamma rays at energies between about 150 and 2,800 keV are detectable with the SGLS. The minimum detection level (MDL) is dependent upon 
detector efficiency at the appropriate energy level, background activity, and the yield (gamma rays emitted, on average, per decay). Factors such as casing, water, shielding, and the presence of other radionuclides also have an effect. Tables E.1 and E.2 summarize naturally occurring and man-made radionuclides that can be detected with the SGLS. The terms "primary gamma ray" and "secondary gamma ray" are used to differentiate between the more prominent gamma energy peaks and other, less prominent peaks that may be useful for confirmation. The values indicated in bold are those generally used to calculate concentrations.

Conventional gamma spectra analysis software is used to detect gamma energy peaks, identify the source radionuclide, and determine the net count rate, counting error, and minimum detectable activity. From the net count rate $\left(\mathrm{P}_{\mathrm{n}}, \mathrm{cps}\right)$ for a specific energy peak, the apparent concentration of the source radionuclide $\left(\mathrm{C}_{\mathrm{a}} \mathrm{pCi} / \mathrm{g}\right)$ is determined by:

$$
C_{a}=\frac{27.027}{Y} \times I(E) \times D T C \times K_{c} \times K_{w} \times K_{s} \times P_{n}
$$

where $\mathrm{Y}$ is the radionuclide yield, $\mathrm{I}(\mathrm{E})$ is the logging system calibration function, DTC is the dead time correction, and $\mathrm{K}_{\mathrm{c}}, \mathrm{K}_{\mathrm{w}}$, and $\mathrm{K}_{\mathrm{s}}$ are energy-dependent correction factors for casing, water, and shielding. The calibration function, $\mathrm{I}(\mathrm{E})$, is unique for each combination of sonde and logging vehicle. Corrections for dead time and shielding were not applicable to the ILAW data. Values of the calibration function are updated annually and documented in calibration certificates and a calibration report (Koizumi 2002). Concentration error and MDL are calculated from count error and minimum detectable activity using similar equations. The reported concentration error is based on only the estimated counting error. No effort is made to include the effects of errors in the calibration function or correction factors. These errors

Table E.1. Naturally Occurring Gamma-Emitting Radionuclides

\begin{tabular}{||l|c|c|c|c|c|c|}
\hline \multirow{3}{*}{ Radionuclide } & \multicolumn{3}{|c|}{ Primary Gamma Rays } & \multicolumn{3}{c|}{ Secondary Gamma Rays ${ }^{(\mathrm{a})}$} \\
\cline { 2 - 7 } & Daughter & $\mathrm{E}(\mathrm{keV})$ & $\mathrm{Y}(\%)$ & Daughter & $\mathrm{E}(\mathrm{keV})$ & $\mathrm{Y}(\%)$ \\
\hline${ }^{40} \mathrm{~K}$ & & 1460.83 & 10.67 & & & \\
\hline${ }^{232} \mathrm{Th}$ & ${ }^{212} \mathrm{~Pb}$ & 238.63 & 43.30 & ${ }^{228} \mathrm{Ac}$ & 911.21 & 26.60 \\
& ${ }^{208} \mathrm{Tl}$ & 2614.53 & 35.64 & ${ }^{228} \mathrm{Ac}$ & 968.97 & 16.17 \\
& ${ }^{208} \mathrm{Tl}$ & 583.19 & 30.36 & ${ }^{228} \mathrm{Ac}$ & 338.32 & 11.25 \\
\hline${ }^{238} \mathrm{U}^{(\mathrm{b})}$ & ${ }^{214} \mathrm{Bi}$ & 609.31 & 44.79 & ${ }^{214} \mathrm{~Pb}$ & 295.21 & 18.50 \\
& ${ }^{214} \mathrm{~Pb}$ & 351.92 & 35.80 & ${ }^{214} \mathrm{Bi}$ & 1120.29 & 14.80 \\
& ${ }^{214} \mathrm{Bi}$ & 1764.49 & 15.36 & & & \\
\hline
\end{tabular}

(a) Secondary gamma rays with yields less than $10 \%$ are not shown

(b) Attainment of secular equilibrium between ${ }^{238} \mathrm{U}$ and ${ }^{214} \mathrm{Bi} /{ }^{214} \mathrm{~Pb}$ requires long time periods on the order of a million years. Activities of both ${ }^{214} \mathrm{Bi}$ and ${ }^{214} \mathrm{~Pb}$ are commonly assumed to be equal to the activity of naturally occurring ${ }^{238} \mathrm{U}$. However, these radionuclides are shortterm daughter products of ${ }^{222} \mathrm{Rn}$, and accumulations of radon gas inside the casing may temporarily elevate the decay activities of ${ }^{214} \mathrm{Bi} /{ }^{214} \mathrm{~Pb}$ relative to the decay activity of ${ }^{238} \mathrm{U}$. 
Table E.2. Man-Made Gamma-Emitting Radionuclides

\begin{tabular}{|c|c|c|c|c|c|}
\hline \multirow[b]{2}{*}{ Radionuclide } & \multirow[b]{2}{*}{ Half Life (Years) } & \multicolumn{2}{|c|}{ Primary Gamma Rays } & \multicolumn{2}{|c|}{ Secondary Gamma Rays } \\
\hline & & $\mathrm{E}(\mathrm{keV})$ & $\mathrm{Y}(\%)$ & $\mathrm{E}(\mathrm{keV})$ & Y (\%) \\
\hline${ }^{60} \mathrm{Co}$ & 5.2714 & $\begin{array}{l}1332.50 \\
1173.24 \\
\end{array}$ & $\begin{array}{l}99.98 \\
99.90 \\
\end{array}$ & & \\
\hline${ }^{106} \mathrm{Ru}$ & 1.0238 & 511.86 & 20.40 & 621.93 & 9.93 \\
\hline${ }^{125} \mathrm{Sb}$ & 2.7582 & 427.88 & 29.60 & $\begin{array}{l}600.60 \\
635.95 \\
463.37 \\
\end{array}$ & $\begin{array}{l}17.86 \\
11.31 \\
10.49\end{array}$ \\
\hline${ }^{126} \mathrm{Sn}$ & $1 . \mathrm{E}+5$ & 414.50 & 86.00 & $\begin{array}{l}666.10 \\
694.80 \\
\end{array}$ & $\begin{array}{l}86.00 \\
82.56 \\
\end{array}$ \\
\hline${ }^{134} \mathrm{Cs}$ & 2.062 & 604.70 & 97.56 & 795.85 & 85.44 \\
\hline${ }^{137} \mathrm{Cs}$ & 30.07 & 661.66 & 85.10 & & \\
\hline${ }^{152} \mathrm{Eu}$ & 13.542 & 1408.01 & 20.87 & $\begin{array}{l}121.78 \\
344.28\end{array}$ & $\begin{array}{l}28.42 \\
26.58\end{array}$ \\
\hline${ }^{154} \mathrm{Eu}$ & 8.593 & 1274.44 & 35.19 & $\begin{array}{l}123.07 \\
723.31\end{array}$ & $\begin{array}{l}40.79 \\
20.22\end{array}$ \\
\hline${ }^{155} \mathrm{Eu}$ & 4.7611 & 105.31 & 21.15 & & \\
\hline${ }^{235} \mathrm{U}$ & $7.038 \mathrm{E}+08$ & 185.72 & 57.20 & 205.31 & 5.01 \\
\hline${ }^{234 \mathrm{~m}} \mathrm{~Pa}\left({ }^{238} \mathrm{U}^{(\mathrm{a})}\right)$ & $4.47 \mathrm{E}+09$ & 1001.03 & 0.84 & $\begin{array}{l}811.00 \\
766.36 \\
\end{array}$ & $\begin{array}{l}0.51 \\
0.29 \\
\end{array}$ \\
\hline${ }^{239} \mathrm{Pu}$ & 24110 & $\begin{array}{l}129.30 \\
375.05 \\
413.71 \\
\end{array}$ & $\begin{array}{l}0.0063 \\
0.0016 \\
0.0015 \\
\end{array}$ & & \\
\hline${ }^{241} \mathrm{Am}$ & 432.2 & $59.54^{(\mathrm{b})}$ & 35.90 & $\begin{array}{l}102.98 \\
335.37 \\
368.05 \\
662.40 \\
772.01\end{array}$ & $\begin{array}{c}0.02 \\
0.0005 \\
0.0002 \\
0.0004 \\
0.0002\end{array}$ \\
\hline (a) $\begin{array}{l}{ }^{234 \mathrm{~m}} \mathrm{~Pa} \text { is a } \\
\text { quickly. B } \\
\text { only backg } \\
\text { gamma pe } \\
\text { and }{ }^{214} \mathrm{Bi} \text { ir } \\
\text { (b) The } 59.54-\end{array}$ & $\begin{array}{l}\text { rt-term daughter o } \\
\text { use of the relative } \\
\text { Ind levels of natura } \\
\text { associated with } \\
\text { cates the presence } \\
V \text { gamma ray may }\end{array}$ & $\begin{array}{l}{ }^{8} \mathrm{U} \text {. Secula } \\
\text { ow gamma } \\
\text { occurring } \\
\text { a without c } \\
\text { hemically } \\
\text { be detectal }\end{array}$ & $\begin{array}{l}\text { ilibrium } \\
\text { 1, this per } \\
\text { are prese } \\
\text { ponding } \\
\text { essed ura } \\
\text { thick ca }\end{array}$ & $\begin{array}{l}\text { achieved rel } \\
\text { is not obser } \\
\text { Hence, the } \\
\text { aks associat } \\
\text { am. } \\
\text { ag. }\end{array}$ & $\begin{array}{l}\text { ely } \\
\text { when } \\
\text { sence of } \\
\text { vith }{ }^{214} \mathrm{~Pb}\end{array}$ \\
\hline
\end{tabular}

are discussed in the calibration report (Koizumi 2002). The term "apparent concentration" is used because the calibration model is based on an effectively infinite, homogeneous distribution uniformly distributed about the borehole axis.

The MDL for a radionuclide represents the lowest concentration at which the positive identification of a gamma-ray peak for that radionuclide is statistically defensible. A description of the MDL calculation is included in the data analysis manual (manual in revision).

On the Hanford Site, ${ }^{137} \mathrm{Cs}$ is the most commonly detected man-made radionuclide. In routine analysis, spectral regions of interest are "forced" for the $662-\mathrm{KeV}$ peak associated with ${ }^{137} \mathrm{Cs}$, and an 
MDL is calculated for each depth, whether or not ${ }^{137} \mathrm{Cs}$ is actually detected. For other man-made radionuclides, MDLs are calculated only when a photon energy peak is detected.

The MDL for ${ }^{137} \mathrm{Cs}$ is typically about $0.2 \mathrm{pCi} / \mathrm{g}$. The MDL differs slightly for each spectrum depending upon count time, background activity and concentrations of other radionuclides at the data point, as well as casing thickness. The MDL for ${ }^{60} \mathrm{Co}$ is about $0.1 \mathrm{pCi} / \mathrm{g}$; the MDL for ${ }^{154} \mathrm{Eu}$ is approximately $0.5 \mathrm{pCi} / \mathrm{g}$; and the MDL for ${ }^{238} \mathrm{U}$ is approximately $14 \mathrm{pCi} / \mathrm{g}$.

Natural and man-made radionuclide concentrations, total gamma count rate, and dead time are plotted as a function of depth. These plots are included in a Log Data Report that also summarizes borehole construction details, logging conditions, analysis notes, and log plot notes, as well as a brief discussion of results and interpretations.

\section{E.3 Results}

Log plots for the three ILAW boreholes are included as Figures E.1, E.2 and E.3. The borehole log data were acquired inside a 4-inch diameter stainless steel casing with 0.125 -inch wall thickness, which had been installed in the 9-inch diameter borehole. The annular space between the casing and the borehole wall was filled with granular bentonite. This completion method resulted in relatively poor detection conditions for naturally occurring radionuclides. Gamma rays originating in the surrounding formation are attenuated by the annular seal between the casing and the borehole wall, and there is interference with gamma rays originating from natural radionuclides (particularly ${ }^{40} \mathrm{~K}$ ) in the bentonite, with the result that total gamma activity is somewhat reduced and the use of potassium, uranium and thorium logs for stratigraphic correlation is impaired.

No man-made radionulcides were detected in the ILAW boreholes. Isolated occurrences of ${ }^{137} \mathrm{Cs}$ at the MDL are shown on the log plots, but these are the result of "forcing" a region of interest for the $661.62 \mathrm{KeV}$ peak in each spectra. Examination of individual spectra in which ${ }^{137} \mathrm{Cs}$ appeared to have been detected failed to provide any evidence of an energy peak at $661.62 \mathrm{KeV}$. These isolated occurrences are most likely the result of statistical fluctuations in the counting process and do not represent credible contamination.

Some difficulties with equipment were encountered during logging. Logging activities began with one SGLS (Gamma 2B) in borehole 299-E17-22, but post-run verification spectra began to fall outside the acceptance criteria. Verification spectra were examined and no immediate cause for the degradation of performance could be determined. Experimental log runs were made with another sonde and it was determined that the source of the problem was most likely in the logging cable or surface data collection system. Repeat logging sections showed significant discrepancies in the ${ }^{232} \mathrm{Th}$ concentration determined from the $2614.53 \mathrm{KeV}$ peak. Comparison of spectra indicated that there appeared to be a loss of efficiency beginning at approximately $2000 \mathrm{KeV}$, and increasing with increasing energy level. All manmade gamma-emitting radionuclides commonly encountered at Hanford are detected and quantified by gamma rays with energies less than $1500 \mathrm{KeV}$. Therefore, the degradation of sensitivity experienced by Gamma 2B does not appear to have a significant effect on detection and identification of man-made radionuclides. 


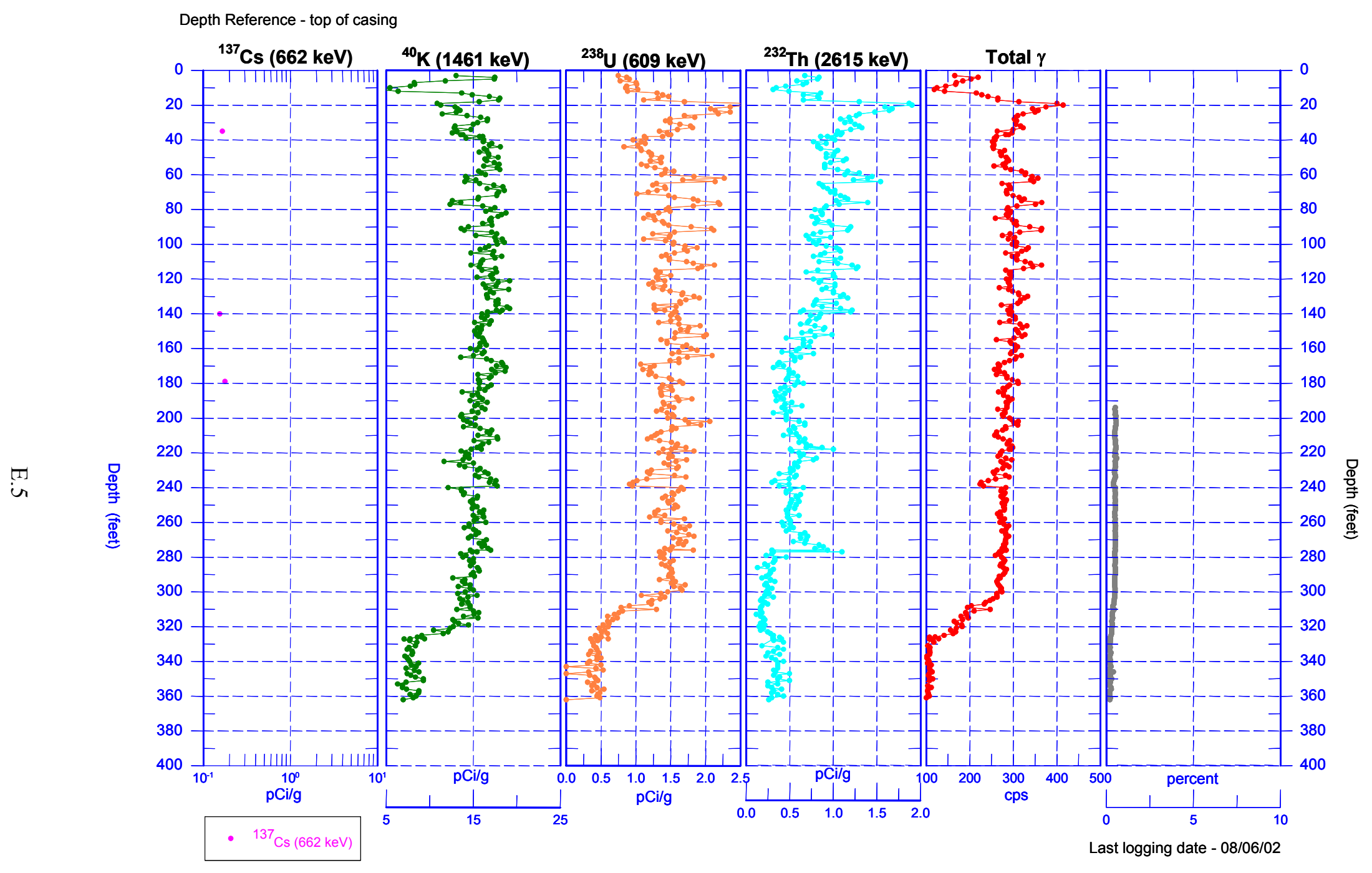

Figure E.1. 299-E17-22 (C3826) Combination Plot 
Zero Reference $=$ Top of Casing

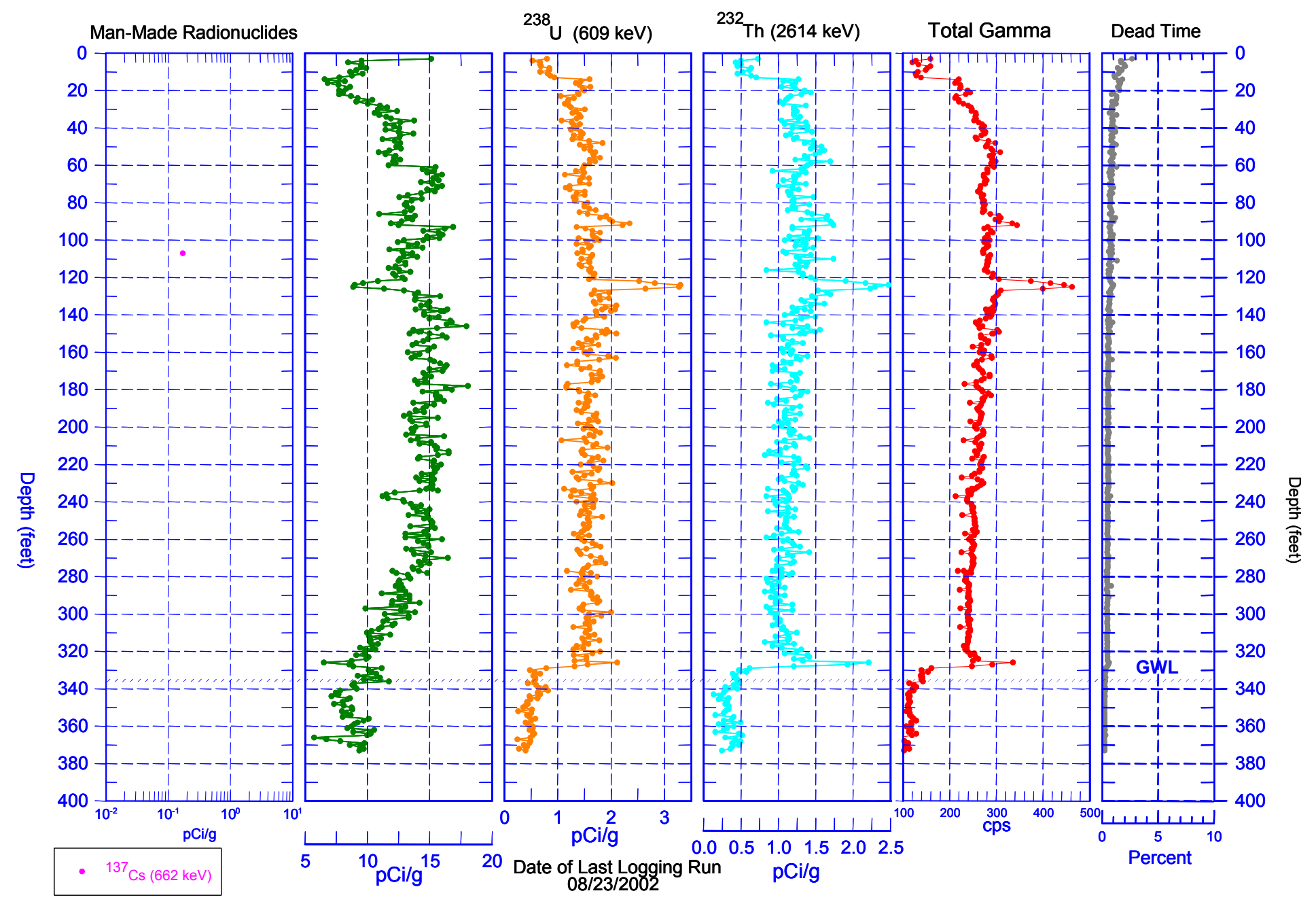

Figure E.2. 299-E17-23 (C3827) Combination Plot 


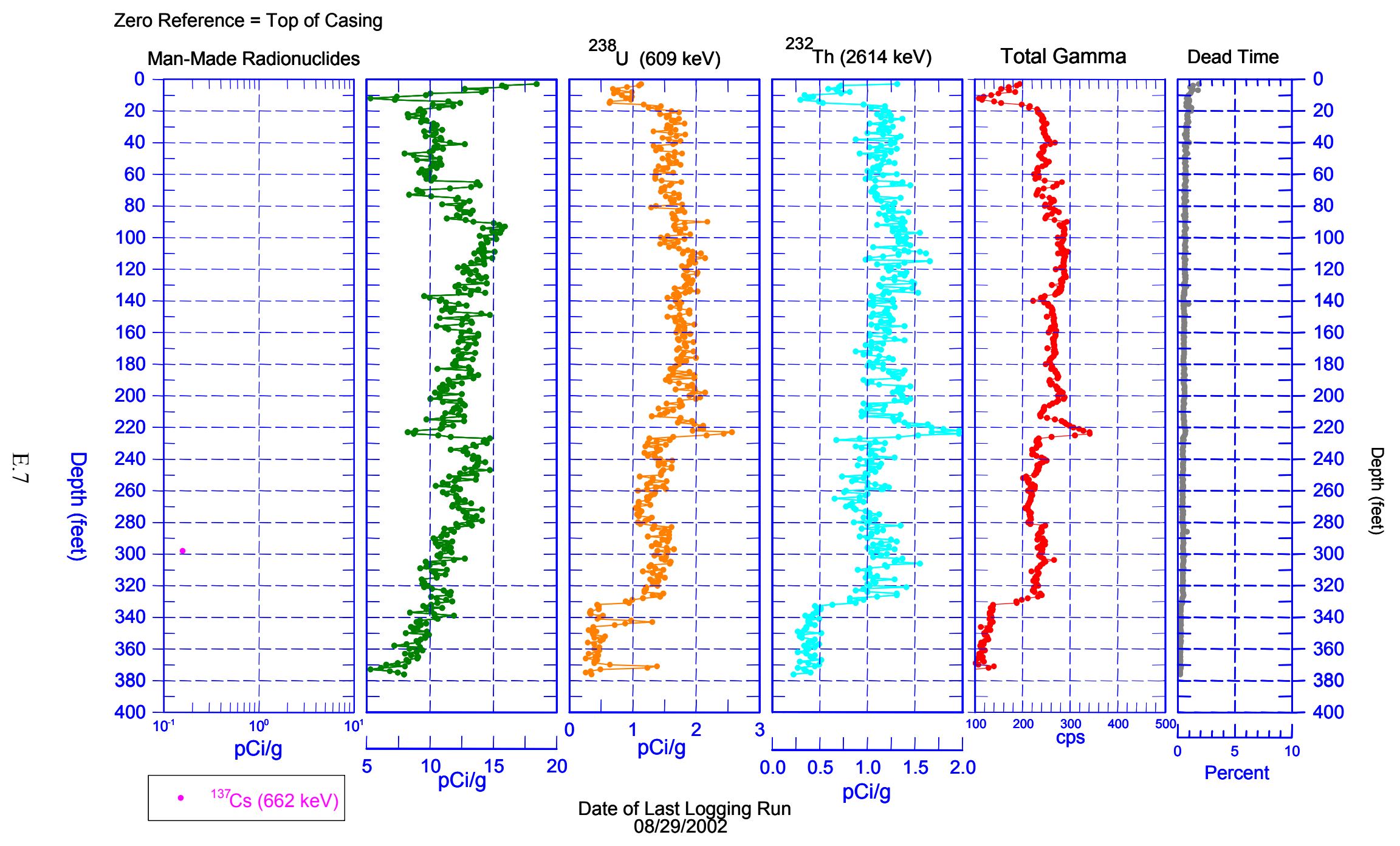

Figure E.3. 299-E17-25 (C3926) Combination Plot 
Another SGLS (Gamma 1D) was used to complete logging in 299-E17-22, and to collect data in 299-E17-23 and 299-E17-25.

\section{E.4 Conclusions}

Spectral gamma logging in three boreholes at the ILAW site provided plots of total gamma, ${ }^{40} \mathrm{~K},{ }^{238} \mathrm{U}$, and ${ }^{232} \mathrm{Th}$ as a function of depth. Except for a few scattered false positive indications of ${ }^{137} \mathrm{Cs}$, no evidence of man-made gamma emitting radionuclides was detected. The annular seal of crushed bentonite (or the sand pack) between the borehole casing and the borehole wall tended to obscure log response, and the usefulness of the logs for stratigraphic correlation was somewhat limited.

\section{E.5 Reference}

Koizumi, C. J. 2002. Recalibration of Logging Systems for Characterization of Subsurface Contamination at the Hanford Site; GJO-2002-328-TAR; prepared by MACTEC-ERS for the Grand Junction Office, Grand Junction, Colorado, April. 


\section{Distribution}

No. of

Copies

ONSITE

5 Fluor Daniel Hanford, Inc.

B. H. Ford

R. L. Jackson

G. A. Jewell

L. D. Walker

C. S. Wright

2 Fluor Daniel Northwest Services, Inc.

R. Khaleel

R. J. Puigh

5 CH2M HILL Group

D. A. Burbank

L6-75

K. C. Burgard

A. J. Knepp

F. M. Mann

D. A. Myers

2 DOE Richland Operations Office

J. G. Morse

J. M. Silko

E6-31

E6-35

A0-21

E6-35

E6-35

B4-43

B4-43

L6-75

E6-35

E6-35

E6-35
No. of

Copies

2 Office of River Protection

C. A. Babel

H6-60

P. E. LaMont

H6-60

\section{Stoller}

R. G. McCain

B2-62

S. Sobczyk

B2-62

Washington State Department of Ecology

J. Caggiano

B5-18

12 Pacific Northwest National Laboratory

R. W. Bryce

E6-35

M. J. Fayer

K9-33

D. G. Horton

K6-81

C. W. Lindenmeier

P8-37

C. T. Kincaid

K9-33

W. J. Martin

K6-81

B. P. McGrail

K9-81

P. D. Meyer

BPO

R. J. Serne

P8-37

S. P. Reidel

K6-81

Hanford Technical Library (2)

P8-55 